Portland State University

PDXScholar

1978

\title{
The history of mutual support organizations among the Chinese in Portland, Oregon
}

Scott Manchester

Portland State University

Follow this and additional works at: https://pdxscholar.library.pdx.edu/open_access_etds

Part of the Chinese Studies Commons, and the Social Work Commons Let us know how access to this document benefits you.

\section{Recommended Citation}

Manchester, Scott, "The history of mutual support organizations among the Chinese in Portland, Oregon" (1978). Dissertations and Theses. Paper 2953.

https://doi.org/10.15760/etd.2948

This Thesis is brought to you for free and open access. It has been accepted for inclusion in Dissertations and Theses by an authorized administrator of PDXScholar. Please contact us if we can make this document more accessible: pdxscholar@pdx.edu. 
AN ABSTRACT OF THE THESIS OF scott Manchester for the Master of Social Work presented May 19, 1978.

Title: The History of Mutual Support Organizations Among the Chinese in Portland, Oregon.

APPROVED BY MEMBERS OF THE THESIS CCOMMITTEE:
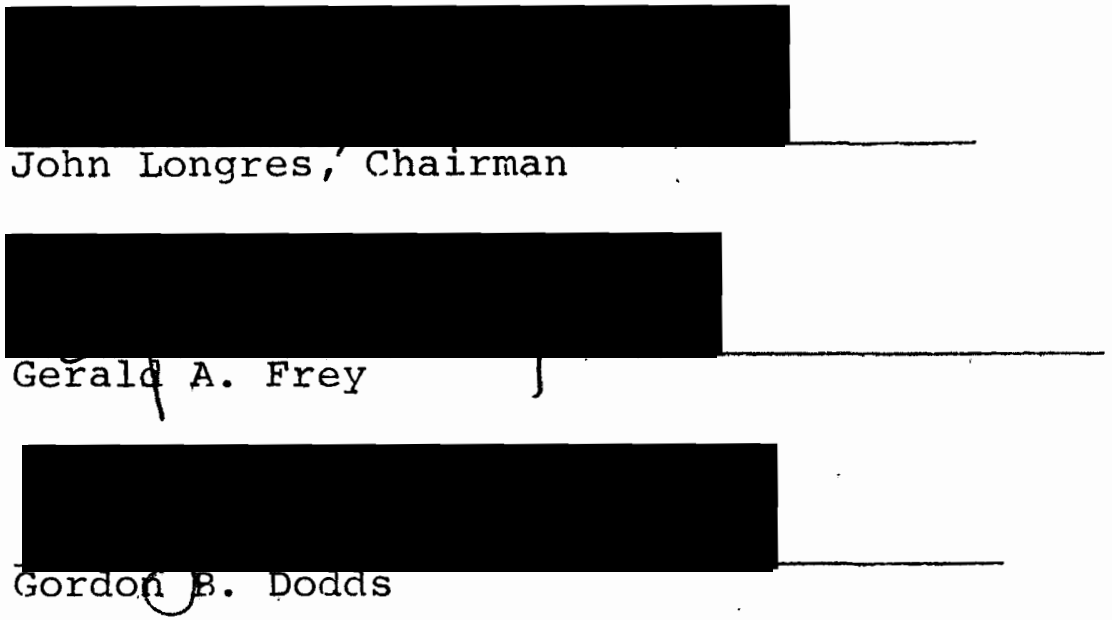

The thesis is an examination of the history of the Chinese community in Portland, Oregon, with special emphasis on the mutual support organizations developed by this community.

The study is primarily descriptive in nature. It includes background information on social, economic, and political conditions in China in the nineteenth century; an account of the history of the Chinese and Chinese organizations in Portland, and an examination of the issues involved in providing social services to Asian communities.

Sources of data include scholarly research, historical records and manuscripts, newspaper articles, and 
interviews with nineteen members of the Chinese community which were conducted by the author. This data is presented in a chronological, narrative form; data from interviews is presented together with other data in the narrative.

The thesis explores the mechanics of racism and discrimination against the chinese, and the effects of such discrimination on the structure of the chinese community.

It examines the different types of organizations which exist and have existed in the Portland Chinese community, and describes the way in which the functions of these organizations have changed over the years.

It defines the present and past concerns and problems of the Chinese community, and the way in which Chinese organizations have attempted to meet these problems.

It compares the Portland Chinese community to other Chinese communities throughout the United States; and also compares the Chinese to other ethnic groups. The thesis concludes that all Asian communities are unique in their cultural traditions, but have historically received similar treatment by the dominant white society.

The thesis also explores issues involved in providing social services to Asian communities, including barriers which prevent chinese from utilizing traditional services; advantages of services designed and operated by the community itself; and the role of the outside professional in helping design services based within Asian communities. The author argues that services specifically designed for 
Asian communities are necessary and can be more effective than services designed for a more general population; but he points out that such programs have not received much understanding or support from the traditional social service structure.

The thesis concludes that the chinese community in Portland has to a great extent been able to retain its cultural identity, traditions, and values; and that community organizations have been instrumental in this achievement. The author takes the point of view that such retention of culture is valuable, and that a plural society is preferable to a "Melting Pot" in which immigrant groups are expected to conform to the life style of the dominant society. 
THE HISTORY OF MUTUAL SUPPORT ORGANIZATIONS

AMONG THE CHINESE IN PORTLAND, OREGON

by

SCOTT MANCHESTER

A thesis submitted in partial fulfillment of the requirements for the degree of

MASTER OF SOCIAL WORK

Portland State Universiţy

1978

(c) 1978 Scott Manchester 
TO THE OFFICE OF GRADUATE STUDIES AND RESEARCH:

The members of the Committee approve the thesis of Scott Manchester presented May 19, 1978.

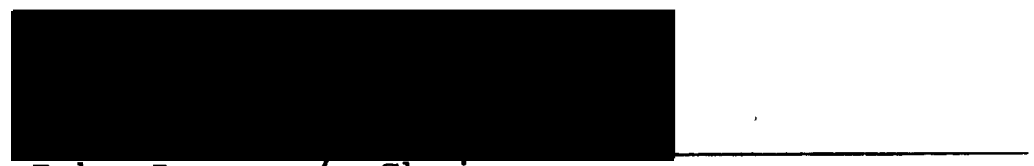

John Longres, Chairman

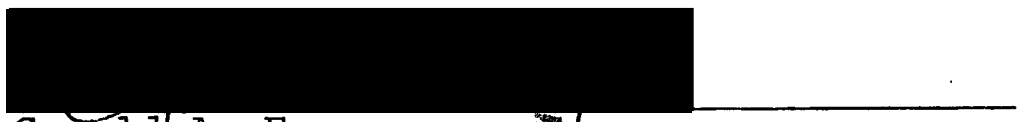

Gerăld A. Frey

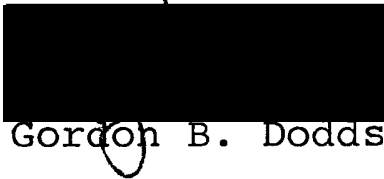

APPROVED :

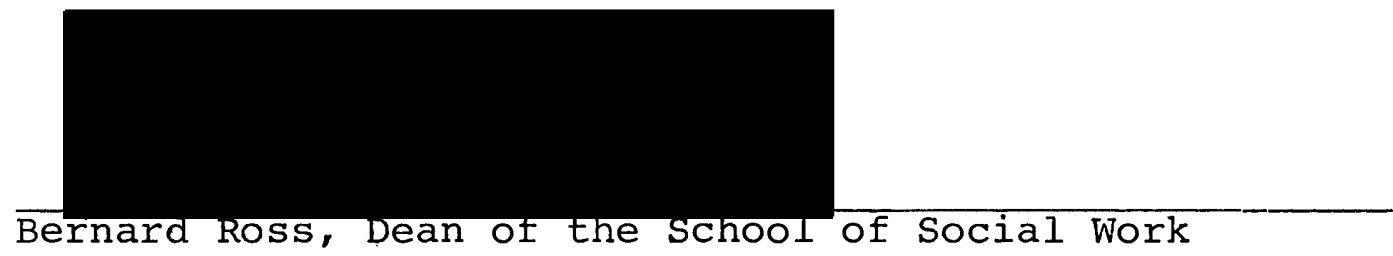

Stanley E. Rauch, Dean of Graduate Studies" and Research 
ACKNOWLEDGMENTS

I would like to thank my thesis committee, Dr. John Longres, Dr. Jerry Frey, and Dr. Gordon Dodds, for the work they did in reviewing the thesis, their many useful comments and suggestions, their support and encouragement, and their patience. I am also very grateful the the staff of the Oregon Historical Society, who helped me to gather inuch of the historical material in this thesis. I am indebted to Chia-lin Chen, whose research on the Chinese in Portland and in Oregon was very helpful, and who, in his correspondence with me, provided many useful suggestions and observations. I especially wish to thank the members of the Chinese community in Portland, and particularly the nineteen people I interviewed, for their interest and cooperation in my work. 
TABLE OF CONTENTS

PAGE

ACKNOWLEDGMENTS . . . . . . . . . . . . . . .

LIST OF TABLES . . . . . . . . . . . . . . . xiii

LIST OF FIGURES . . . . . . . . . . . . . . . xiv

CHAPTER

I INTRODUCTION . . . . . . . . . . . . . 1

Social Service Needs . . . . . . 2

The Organization of the Thesis... . 3

Themes and Points of View . . . . . 5

Limitations of the Study . . . . . . 8

Sources of Data . . . . . . . . . . . 9

II INTERVIEWING PROCEDURES AND METHODOLOGY • • 12

Use of Interviews in the Thesis. . . 12

Purpose of the Interviews . . . . . 13

Sample Characteristics . . . . . . 13

Interviewing Procedures . . . . . . . 19

Response to Interviews ........ 20

\section{PART I}

CULTURAL, POLITICAL AND ECONOMIC ANTECEDENTS OF THE CHINESE EXPERIENCE IN THE UNITED STATES

III CHINESE IMMIGRATION AND IMMIGRANTS . . . 
Chinese Society in the Nineteenth

Century • • • • . • • . • • . 24

Social structure

power Structure

Class Structure

Family structure

Social Restraints on Emigration

Conditions in Nineteenth Century

China

Characteristics of Chinese Immigrants . . 34

The Immigrant as Sojourner

Immigrants as an All-male society

Restrictions on Having a Family

Characteristics of the Immigrants

Motivations of the Chinese Immigrants . •

Theories on Motivations of the Immigrants

Accounts by Immigrants of their Motivations

Methods of Immigration . . . . . . . .

The Case for Involuntary Immigration

The Case Against Forced Immigration

Specific Inaccuracies in Barth's Thesis

Methods of Financing Immigration

IV CHINESE-AMERICAN RELATIONS DURING THE PERIOD OF CHINESE IMMIGRATION •. • • • • • • • 57 Introduction . . . . . . . . . . . 57

The Diplomatic Structure in China in the Nineteenth Century . . . . . . . .

Chinese Attitudes Toward Foreigners Bureaucratic Organization of Foreign Affairs

The Colonization of Coastal China by the West

Trade, Treaties, and War

Foreign Domination of Chinese Diplomacy 
Western Attitudes Toward the Chinese

China as a colony of the West

The Conduct of Chinese-American Relations,

1862-1905............

The "Coolie Traffic"

Free Immigration

The Burlingame Treaty

Anti-Chinese Hostility

The Angell Treaty

The Exclusion Act of 1882

Anti-Chinese Riots, 1885-1886

The Bayard-Chang Treaty

The scott Bill

The Geary Act

The Gresham Treaty

Implementation of the Exclusion Laws

Extension of Exclusion and Chinese Reaction

Relations With the Nationalist

Chinese Government

Repeal of Exclusion and Recent Relations With China

Comparison of the Chinese and Japanese Experience

The Chinese in America as a Colonized

Minority . . . . . . . . . . .

Theories on the Mechanisms of Racism

Blauner's Thesis on "Colonized

Minorities"

The Criterion of Involuntary Immigration

Unfree Labor Conditions

Restriction on Freedom of Immigration

Restricted Mobility

Restriction to Preindustrial Labor

Cultural Imperialism 


\section{PART II}

THE HISTORICCAL EXPERIENCE OF THE CHINESE IN PORTLAND

$V$ THE EARLY YEARS OF THE CHINESE IN PORTLAND, 1851-1880 . . . . . . . . . . . 178

The Arrival of the Chinese in Portland, . 118 Arrival of Chinese in Portland

Statistics on Chinese Immigration and Population .......... . 121

Chinese Population

Chinese Immigration

Occupations of Early Chinese Immigrants . . 124

Chinese Merchants

Rural Labor

Work on the Railroads

Other Areas of Employment for Chinese

Urban Employment of the Chinese

Reaction of the White Population to

Chinese Immigration.......... 131

The Beginnings of Hostility Towards Chinese

The Situation in Urban Areas

Anti-Chinese Organizations

Political and Legal Discrimination

The Chinese Community in Portland . . . . 136

The Formation of "Chinatowns"

Chinese Organizations

Organizations in Portland

Chinese Missions and Temples

Leadership of the Portland Chinese Community

VI EXCLUSION AND PERSECUTION OF CHINESE, 18801905

The Causes of Anti-Chinese Hostility . . . 156

Social and Economic Factors 
The Racist Nature of Anti-Chinese Hostility

"Cheap Chinese Labor"

other Arguments Against the Chinese

The Anti-Chinese Riots, 1885-1887 . . . . 162

The Workingmen's Party

The Utility of Anti-Chinese Racism

to Labor Organizers

The Pattern of Anti-Chinese Hostility

Anti-Chinese Riots on the West Coast?

Anti-Chinese Riots in Seattle

Events in Portland

Governor Sylvester Pennoyer

Anti-Chinese Legislation . . . . . . 172

Early Legislation in California

Legislation in oregon

Federal Legislation

Effect of Exclusion on the Chinese

Changing Attitudes Towards the

Chinese

The Chinese Community in Portland . . . . 177

Chinatown Lifestyle

Chinese Organizations

Summary • . • . . . . . . . . . 186

VII THE TIME OF TRANSITION, 1905-1943 • • • • • 195

Continued Restriction on Immigration . . 195

Anti-Chinese Legislation

Application of the Exclusion Laws

Illegal Immigration

The Repeal of Chinese Exclusion

Employment Opportunities for Chinese • . . 202

Continuation of Traditional Employment Patterns

Employment Discrimination

Labor Unions

Opening Up of Employment Opportunities for Chinese 
The Portland Chinese Community . . . , 207.

The Lifestyle in Chinatown

Retention of Culture, Assimilation, and Integration

Housing

Family structure

Education

White Attitudes Towards Chinese

Chinese Organizations in Portland,

1905-1943........... . 215

Tongs and Tong Wars in Portland

The Peace Society

The Portland Chinese Consulate and Other Chinese Government Organizations

The Chinese Consolidated Benevolent Association

The Chinese Language School

Family and District Associations

Civil Rights Organizations

The Chinese Women's Club-

Student and Youth Groups

Cultural Organizations

Chinese Churches

Summary . . . . . . . . . . . 237

PART III

THE CONTEMPORARY COMMUNITY

VIII. THE CONTEMPORARY CHINESE COMMUNITY IN PORTLAND,

1943 TO THE PRESENT . . . . . . . . . . 247

Introduction . . . . . . . . . 247

The Decline of the Portland Chinatown . . 249

The Importance of Chinatown to the Chinese Community

The Dissolution of the Portland Chinatown

Present Conditions in the Chinatown Area 
Living Conditions and Extent of Continued Discrimination

Continuation of Discrimination

Discrimination in Employment

Housing

Education

Social Problems of Several Groups in the Chinese Community . . . . . . . . 262

Problems in Other Cities

The Aged

Immigrants

Students

Youth

Continuing Sense of Community Among the

Chinese . . . . . . . . . . . 283

Power Structure of the chinese Community . 287

Political Activism

The Traditional Conservatism of Chinese Leadership

Attitudes of Community Leadership

Concerning the Chinese Community

Factionalism and Cooperation in the Portland Community

The Present State of Chinese Organi-

zations . . . . . . . . . . . 294

The Chinese Consolidated Benevolent Association

Family and District Associations

Tongs

The Chinese-American Citizens

\section{Alliance}

Professional Associations

The Chinese Chamber of Commerce.

The Chinese Women's Club-

Cultural Organizations

The Chinese Consulate

Chinese Churches

The Future of the Chinese Community in portland . . . . . . . . . 308J 
Community Goals

Continuation of the Chinese

Community

Summary • • • • • • • • • • • • 313

IX DIFFERENCES IN THE EXPERIENCES OF VARIÖUS ASIAN

GROUPS

The Portland Chinese Community Compared

With Other Chinese Communities . . 320

Population

Lack of Hostility

Portland as an Urban Community

Present Status of the Portland

Chinese

The Experience of Other Asian Groups • ; 324

The Japanese

Filipinos

Koreans

Indochinese

Pacific Islanders

Common Interests and Efforts of Asian

Groups ............ . 336

Examples of Inter-Asian Cooperation

Inter-Asian Cooperation in Portland

$x$ SOCIAL SERVICES FOR ASIAN COMMUNities . • • 343

The Myth of the "Model Minority". • • , 344

Effects of Such Stereotypes on the

Struggle for Racial Equality

Effects on Funding for Asian Programs

Special Needs of Asian Groups . . . . . 348

Culture-specific Problems

Review of Problem Areas in Asian

Communities

Barriers to Service . . . . . . . 350

Powerlessness

Lack of Cultural. Sensitivity

Need for Bilingual Staff 


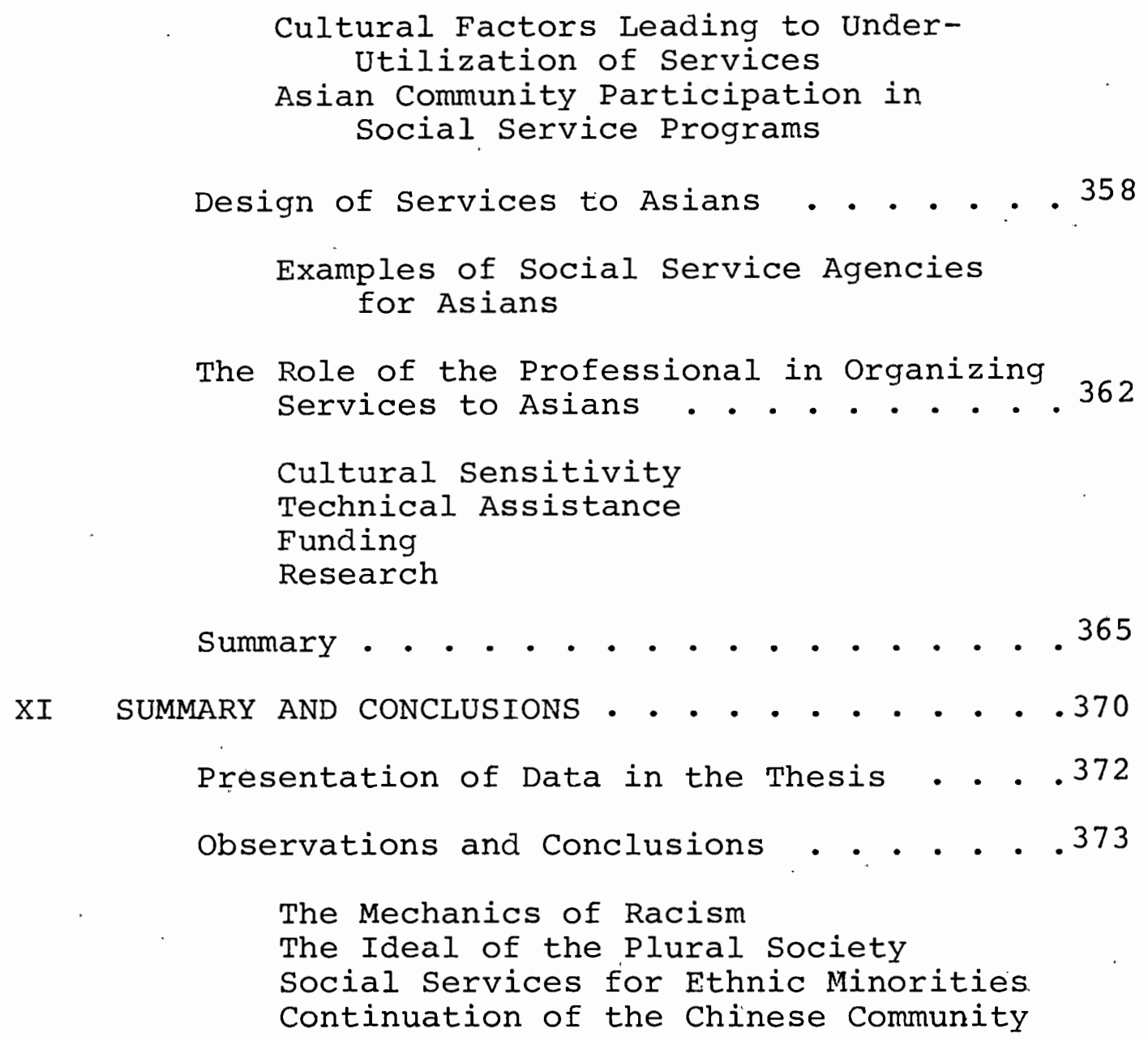

BIBLIOGRAPHY . . . . . . . . . . . . . . 380

\section{APPENDICES}

APPENDIX A INTERVIEW SCEEDULE AND CONTACT LETTER • . 396

APPENDIX B A CHRONOLOGY OF THE PORTLAND CHINESE COMMUNITY ...............400.J

APPENDIX C CONSTITUTION OF THE CHINESE CONSOLIDATED BENEVOLENT ASSOCIATION OF PORTLAND . .404 


\section{LIST OF TABLES}

1

TABLE

PAGE

I. Characteristics of Interviewees . . . . . . . . 15

I Chinese in Portland and in the state of Oregon,

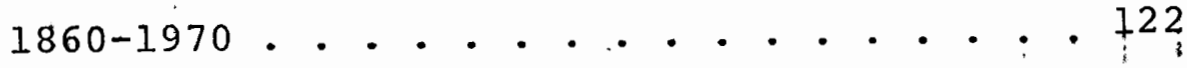




\section{LIST OF FIGURES}

1. Map of Kwangtung Province, China . . . . . 25

2. Portland Chinatown, 1880's. S.W. Second and Alder . . . . . . . . . . . . . 138

3. Portland Chinatown, c. 1890. Second Street, looking South to Washington ...... . 139

4. Chinese Temple, 64 1/2 S.W. Second Street, c. 1900 . . . . . . . . . . . 183

5. Chinese Children on S.W. Second Street, c. 1900 . . . . . . . . . . . . 184

6. Distribution of the Chinese Population in Portland, Oregon, 1938 . . . . . . 210

7. Distribution of the Chinese Population in Portland, oregon, 1970 . . . . . . 255 
CHAPTER I

INTRODUCTION

Because of our destitution. I went out, trying to make a living. Who could know that the Fate is always opposite to man's design? Because I can get no gold, I am detained in this secluded corner of a strange land. Furthermore, my beauty, you are implicated in an endless misfortune.' I wish this paper would console you a little. This is all that I can do for now...

$$
\begin{aligned}
& \text {--excerpt from an unfinished letter } \\
& \text { from a miner in John Day, Oregon } \\
& \text { to a wife in China.1 }
\end{aligned}
$$

In the 1840's, Chinese began to come to America seeking fortune as miners, laborers, cooks, and servants. They were motivated in coming here by various conditions in China: famines and epidemics, economic and political upheavals, and foreign oppression. By the early 1850's Chinese began to find their way to Portland, Oregon; which was at that time merely a small settlement on the Columbia. They came, originally, not as permanent residents, but as sojourners: trying to make money in what they had heard was a rich land full of opportunity, so that they could return to china in a position of respect, and provide money to support their families and themselves.

Finding themselves in a strange and often hostile environment, they naturally banded together for mutual support and protection. They developed formal organizations similar to those they knew in China in order to work together to 
find jobs, protect themselves from injustice, negotiate with the "barbarian" whites whose country they were in, and provide consolation to each other.

This thesis will examine the history of these groups in Portland. As the white perception of the Chinese community has changed from that of an alien "Yellow Peril" to "model minority", and as the Chinese themselves have changed from naive, uneducated immigrant laborers to sophisticated and respected members of the community, the roles and functions of the Chinese organizations have also changed. A study of such developments can tell us something about the sociology of immigrant groups and about the process of acculturation. But it can also tell us about white racism, discrimination, and racial stereotyping; and about the current needs and problems of a minority group which has been by and large completely ignored by the social service institutions in this area.

\section{SOCIAL SERVICE NEEDS}

Probably no ethnic minority group has ever put so much effort into the mutual support of its members as has the Chinese community in the United States. But this commendable characteristic has recently had unfortunate consequences for the Chinese people. $A$ myth has developed among the white community and the ruling elites that "the Chinese help their own"; and that therefore the Chinese community needs no support from the surrounding white community. The Chinese 
community does put a high value on "helping its own", but its resources are limited, and many needs remain unmet. There is increasing interest in the field of social services in client and community organized services, and this thesis will thus provide some data on the experience of the Chinese in organizing such services.

An Asian American Task Force of the Council on Social Work Education (CSWE) reported in 1973 that:

There is a lack of information and descriptive data on who the Asian Americans are; where they come from and when; their hopes, fears, and stresses; and the ways they attempt to maintain stability in the urban scene. ${ }^{2}$

The purpose of this thesis is to provide such information. The historical focus of this thesis is believed to be necessary and important to the understanding of the Chinese in Portland. As Victor G. and Brett DeBary Nee state about the Chinese community in San Francisco:

The longer we lived in Chinatown, the more we came to sense that its present configuration grew out of a past which we had not yet clearly grasped. The weight of this past seemed to be an integral part of the consciousness of people in the community and to continue to affect their behavior... 3

\section{THE ORGANIZATION OF THE THESIS}

The thesis is organized into three parts: Part I (Chapters. III and IV) is an introduction to the chinese in the United States; it includes a chapter characterizing the Chinese immigrants and the nature of Chinese immigration in the nineteenth century and a chapter on the social, political, 
and economic factors which determined the position of the Chinese in American society. Specifically, we wish to examine to what extent China was in a subordinate or colonial relationship to the United States during this period. One of our themes is that the relationship between the U.S. and China determined at least in part the manner in which Chinese immigrants were treated in the U.S. In that few Americans have much knowledge of the cultural antecedents of the chinese community (the prevailing stereotype still sees the Chinese as "inscrutable" and their values as inexplicable), we feel the attention devoted to such topics in Part I to be essential.

Melford Weiss has identified three historical stages in the development of Chinese communities: "The Era of the Traditional Chinatown", from the 1850's to c.1900; "The Time of Transition", c.1900-1943; and "The Contemporary Community", from 1943 to the present. 4 Part II of our thesis is organized roughly around these stages. The first stage is covered in two chapters: Chapter, $V$ deals with the arrival of the Chinese in Portland; and Chapter VI deals with the period of intense hostility against the Chinese (1880-1905). Chapter VII deals with Weiss' second stage, 1905 to 1943.

Part III of the thesis deals with the structure of the contemporary Chinese community in Portland. Chapter VII outlines the organizations, leadership, problems, and goals of this community: Chapter IX is a comparison of the Portland Chinese community to Chinese communities in other cities, and 
to the communities of other Asian groups. It should be emphasized that the Portland Chinese community is in many ways unique -- it is an urban community; it is much smaller than similar communities in California and in New York City; there is no Chinatown to speak of in Portland, and yet there is a strong Chinese community; and Portland has experienced less overt hostility and repression than have similar communities elswhere. In one sense, these aspects of the Portland Chinese community simplify our task in analysing it; but at the same time, we must discuss the extent to which our findings apply to other Asian communities. Chapter $\mathrm{x}$ reviews the implications of our study for the planning and practice of social services. This chapter analyzes the experience of Portland Chinese organizations in order to document the theme that services specifically designed for small minority communities can have great validity and effectiveness. We also attempt to define a role for the professional in providing technical assistance to minority community service projects. Our findings and conclusions are summarized in Chapter XI.

\section{THEMES AND POINTS OF VIEW}

This thesis will attempt to demonstrate that the many mutual support organizations present in the chinese community throughout its history have, in their development, served to accurately reflect the changes and development taking place in the community itself. The Chinese in Portland have formed 
these organizations as a way of implementing their goals, values, and distinct identity as a people. As the goals and identity of the Chinese in Portland have changed, so have their organizations.

The type of organizations to be discussed generally fall into three categories: First, there are traditional organizations originally modelled on community organizations common in the China of the nineteenth century. These include family associations, and the so-called "tongs", which in China were political and protective organizations. Second, there are organizations with cultural functions. These include Chinese language schools; religious groups (missions, churches, temples); and cultural and social organizations (music societies, youth groups, etc.). Third, there are organizations modelled on American structures. These include the ChineseAmerican Citizens Alliance (a civil rights group) the Chinese Chamber of Commerce; and various associations for Chinese professionals. Unifying and coordinating this extraordinary web of community groups is the chinese consolidated Benevolent Asșociation (CCBA), which includes representatives from all these groups and acts as the spokesman for the Chinese community as a whole.

Today in Portland there is no longer a "Chinatown"; the Chinese live throughout the city, and are fairly well integrated socially into the American society. Many writers have theorized that the degree of organizational structure in the community would be inversely related to the degree of 
assimilation into the broader society, ${ }^{5}$ and that community organizations would not be able to continue if a physical Chinese community ("Chinatown") ceased to exist. But in Portland the Chinese, while identical with most Americans in almost all characteristics other than race and ancestry, have retained a strong sense of identity as Chinese people; and this is demonstrated by the continuation of their organizations. The ability of a proportionately small ethnic group to retain a distinct identity in the face of great pressure for assimilation is one of the central phenomena to be explored in this thesis.

Our study is intended to be primarily descriptive and objective, but several distinct themes underlie our interpretation. First is the idea, referred to above, that the Chinese have been, in different historical periods, subjected to both great discrimination and hostility and great pressure for complete assimilation. The mechanisms of these pressures, and the way in which the Chinese have sought to cope with them, is a major thematic basis for the thesis.

A second unifying theme is the idea that ethnic groups have a right to their heritage and identity; and that as a distinct group in the population, they have both weaknesses and strengths that are to a certain extent unique. We believe that there are special needs, values, and goals that come out of the cultural and historical experience of the Chinese; and that in designing social services one must take account of these factors. A social service system sensitive 
to the needs of the Chinese people would allow for community self-design of services, employment and training of culturally sensitive professionals, and an allocation of resources which recognized the existence of a population with a language, culture, problems, and values differing from those of the majority society. We are thus writing from a viewpoint which sees American society as a pluralist structure, including many different peoples and ideas; rather than a "melting. pot" in which the ideal is eventual conformity of all societal elements to the standards. of the white middle-class.

\section{LIMITATIONS OF THE STUDY}

Several factors limited the scope and thoroughness of our research. First, the writer is not Chinese, does not know the Chinese language, and began his research with no contacts in the Chinese community. White authors writing about the Chinese are perhaps inevitably biased by a lifetime of exposure to stereotypes and lack of real contact with people of color. A white American could be assumed to have less sensitivity and less knowledge of the Chinese community than a Chinese American would have.

Also, time limitations severely restricted the amount of work that could be done. And this study received no funding from any source. Thus, we were unable to transcribe interview tapes, travel extensively, or order any great quantity of literature from publishers or libraries outside of this area. 
Because of these factors, our study must be viewed as tentative and exploratory. Probably the best Chinese community study, the Nees' Longtime Californ.6 took two people two years of fulltime work to complete, with funding from the Ford Foundation and from private sources. We had no such resources available.

SOURCES OF DATA

Our methodology includes two elements: First, we have attempted to research all available written materials, historical records, and professional literature on the Chinese in America and in Portland. We were able to obtain a great deal of historical information. The sources available at the Oregon Historical Society were especially valuable. But there are still considerable gaps in our account. Few of the early Chinese laborers left written records. Chen observes that "One of the crucial problems facing the researcher in the field of early Chinese immigration history is the lack of original materials." 7 Chen himself has provided some such materials (such as the poignant statement that opens this chapter), and there are a f'ew other scattered accounts by the Chinese themselves of their experience. But up" until fairly recent times, the primary sources on the chinese have been whites writing in newspapers and pamphlets, and these accounts are often so obviously hostile and inaccurate that they are of little value. 
Scholarly writings on the Chinese are also sketchy. The Oregon Historical Quarterly, for instance, which has been in existence for seventy-eight years and 312 issues, has only had one article directly dealing with the history of the Chinese in Oregon, and that only last year. Some articles exploring social services for Asian populations do exist, but these are also few and far between.

It is difficult even to obtain demographic data on the Chinese population. The 1970 Census of Population and Housing for the Portland SMSA lists by census tract only the categories "White", "Negro", "Persons of Spanish Language", and "Other". "Other" includes Asian and Pacific peoples as well as American Indians and all other ethnic groups. The census provides information on nativity and parentage for fourteen European and American nationalities, but categorizes all other nationalities under "All other and not reported". The 1970 census for Oregon does indicate the number of Chinese in Portland, but there is no published data on Chinese by census tract (although we were able to obtain such information from a Bureau of the Census computer printout).

We hope that this study will prove helpful to future researchers and to those interested in planning services to minority groups. We feel it gathers together much diverse information which is useful in gaining an understanding of a hitherto ignored minority community in Portland. 
${ }^{I}$ Chia-lin Chen, "A Gold Dream in the Blue Mountains: A Study of the Chinese Immigrants in the John Day Area, Oregon, 1870-1910" (Masters thesis in History, Portland State University, 1972) p. 141. Translated from Chinese by Chia-lin Chen, date unknown.

${ }^{2}$ Council on Social Work Education, Asian American Task Force, Asian American Task Force Report: Problems and Issues in Social Work Education. (N.Y.:CSWE, 1973) p. 40.

${ }^{3}$ Victor G. and Brett De Bary Nee, Longtime Californ': A Documentary Study of an American Chinatown (N.Y.:Pantheon Books, 1973)', p. xviii.

4 Melford S. Weiss, Valley City: A Chinese Community in America (Cambridge, Mass.:Schenkam Publi'shing Co., 1974), pp. 6-7.

${ }^{5}$ ibid., p. 7.
${ }^{6}$ Nee, op. cit.
${ }^{7}$ Chen, p. iii. 


\section{INTERVIEWING PROCEDURES AND METHODOLOGY}

Some of the information presented in this thesis was based on interviews of members of the chinese community in Portland conducted by the author:

We felt it essential to meet members of the chinese community face to face. A previous study by three Chinese social work students at Portland state, which used a questionnaire instead of interviews, concluded that:

If the method of interviewing was used, unclear questions or doubts could be pointed out by the respondents and immediate correction could have been made. But this method would have been too time consuming. I

\section{USE OF INTERVIEWS IN THE THESIS}

We have organized our thesis in a chronological, narrative form. Therefore, data. we have elicited from interviews will be introduced into the narrative along with other sources of data (i.e., information from historical records, scholarly literature, etc.)., We will not have any special chapter or section detailing the information received through interviews. We believe that this strict chronological format allows for a more intelligible and less redundant presentation of information. 
PURPOSE OF THE INTERVIEWS

Nineteen such interviews were conducted. The purpose of the interview was to elicit information from the informants concerning general impressions of life in Portland; life history data; difficulties in coping with life in America; experiences of racial discrimination or hostility; experiences in organizing or dealing with ethnic community groups; and the history of these groups. A copy of the interview schedule used for this purpose is included in Appendix A.

All interviews were recorded on tape cassette. Some interviewees expressed reservations about this procedure, but when it was explained that recording of the interview would insure accuracy in any citing of the interview in the thesis, all interviewees agreed.

The interviews proved useful in getting data on the attitudes of people in the Chinese community concerning their identity as Chinese and their ideas about the Chinese community -- its goals, future, and structure. The interviews were less useful in eliciting historical information, although we did obtain some useful accounts of the lifestyle of the Chinese in Portland in years gone by.

\section{SAMPLE CHARACTERISTICS}

Our sample, consisting of nineteen people, was very small; and thus the extent to which it was or was not 
representative of the Chinese community as a whole is an important question.

Descriptive data on each of these interviewees is provided in Table I. The mean age of our informants was 49.7 years, and ranged from 18 to 67 years. Six of the interviewees were female, thirteen were male. Eight of the interviewees were born in America; eleven were-born overseas. Of this latter group, nine were recent immigrants or students ("recent" being defined as within the last twelve years). One had been in America since 1925, and one had been here since the early 1960's. The mean length of residence for the recent immigrants was 3.9 years, and ranged from five months to twelve years. These immigrants came from a variety of places. Three were born in mainland China, although two of these individuals immigrated here from Hong Kong. Four others of these immigrants were born in Hong Kong; two were from Taiwan; one waș from Burma; and one was from Indonesia. Thus, of the immigrants we interviewed, nine were born in some area of China and two came to America from another overseas Chinese community.

It is impossible to determine how closely the above demographic data correlates with data for the total Chinese population in the Portland area. No data on age, sex, place of birth, or length of U.S. residence is available on the Chinese in Portland. We can assume that an unrepresentatively large number of males were interviewed, although it should be mentioned that males probably still outnumber 


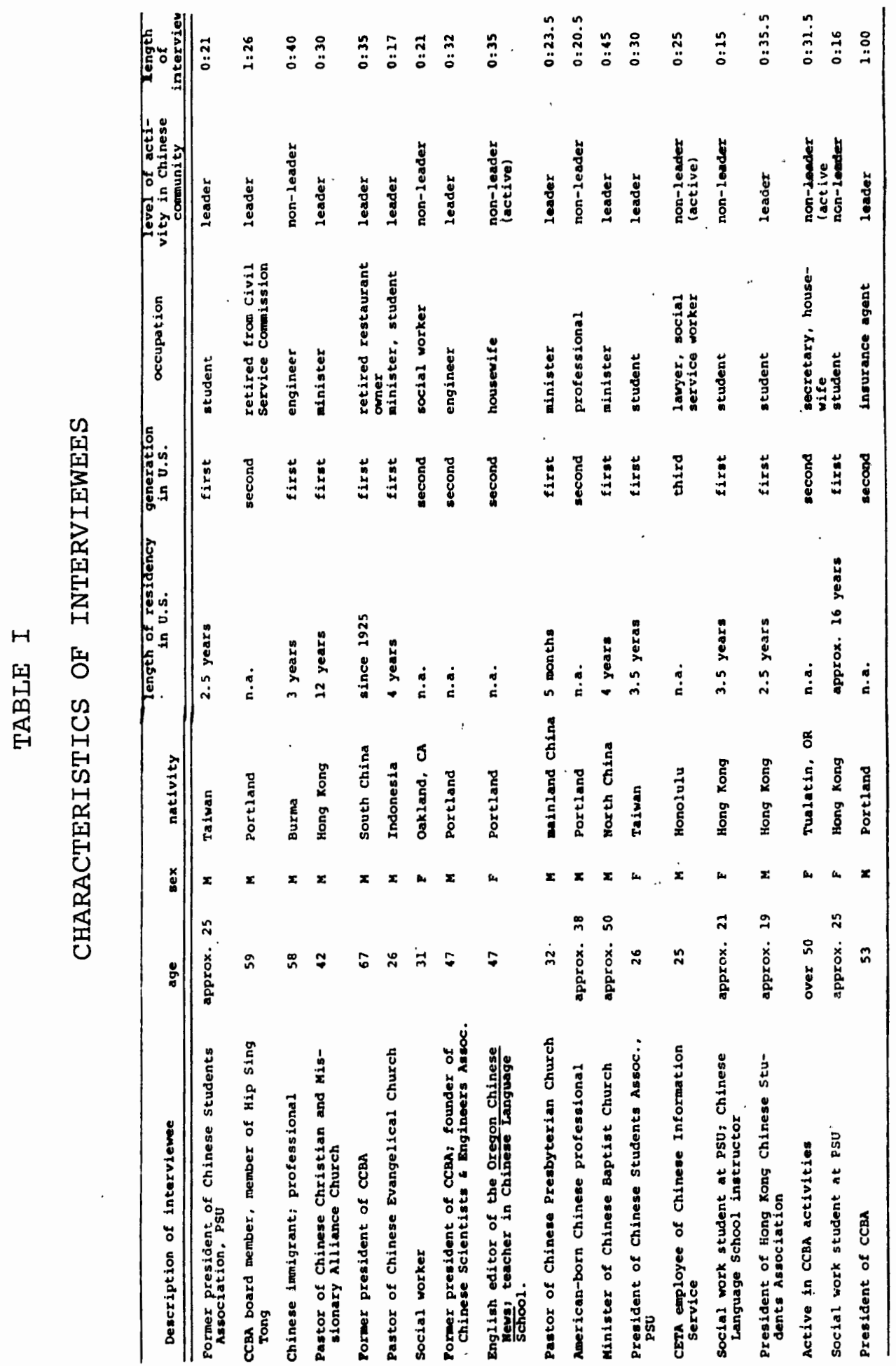


females in the Chinese community to a certain extent. Our sample may also be biased in favor of immigrants; although this may or may not be true, due to the large number of Chinese who have immigrated to Portland in recent years.

We attempted to achieve a balance between older people and younger people in our sample; but because of the large number of students interviewed, we were concerned that our sample might be biased in favor of young people. But although we don't have figures for the chinese population, in the general population of the Portland SMSA, $35.7 \%$ of the population is between 18 and 34 years of age. ${ }^{2}$ of our sample, seven individuals, or $37 \%$ fell into this age range. Our sample thus contains a proportion of individuals aged 18 to 34 which is roughly equal to the proportion found in the general population.

Two other factors are also important in considering the representativeness of our sample. First is the occupation of our informants. Many occupations were represented among the interviewees, including ministers, engineers, civil service workers, housewives, social workers, lawyers, insurance agents, restaurant and shop owners, and students.

Ten of the interviewees (53\%) can be considered to be in self-employed, professional or managerial areas of employment. This percentage is considerably higher than that of the general population. (According to the 1970 census, 25.7\% of the employed population of the Portland SMSA is engaged in self-employed, professional or managerial occupations.) ${ }^{3}$ 
Again, however, the Chinese population could be expected to have a larger number of professionals than the general population, although certainly not as large a percentage as our sample.

Also, none of our sample was unemployed (although one individual had recently experienced a period of unemployment). Considering the difficulty of recent immigrants in particular of finding jobs, this again indicates an area where our sample is probably not representative.

Due to the nature and restraints of our interviewing process, two occupations were grossly overrepresented. First, we interviewed the ministers of all four of the Chinese churches in Portland. It was considered important to do this, because the churches form a central focus for Chinese community activity. But this also resulted in ministers representing $21 \%$ of the total sample.

Also, we interviewed many students. These students were either attenting the School of Social Work at PSU or were officers in one of the two Chinese student organizations at PSU. In one case, a seminary student who is the provisional pastor of one of the Chinese churches was interviewed. In all, six students were interviewed. There were several reasons for interviewing so many students. First, the author is himself a student, and it was easy and convenient to contact other students at PSU. Secondly, Chinese student organizations were considered an important and unique type of mutual support organization; and it was considered essential 
that information be obtained on these groups. Also, because of the emphasis of the thesis on social services, the author wished to interview as many Chinese social workers as could be found in the Portland area. Very few social service workers in Portland are Chinese, so we were only able to contact one practicing Chinese social worker. However, there are two Chinese or Chinese-Americans currently studying social work at PSU, and we were able to interview both these individuals.

Another sampling difficulty arose from the fact that many interviewees were leaders in the Chinese community. We naturally wished to talk to as many Chinese community leaders as possible, but this also tended to bias our sample. The leaders can be assumed to have different ideas and attitudes about their Chinese identity; more commitment to the Chinese community and its organizations (by definition they are more active in such organizations); and probably have better paying and more prestigious jobs than the balance of the Chinese population.

In Table I, we categorize our interviewees as either "leaders", "non-leaders (active)", or "non-leaders". For purposes of this table, a leader was defined as an individual who holds, or has recently (within the last year) held an official office in one of the Chinese organizations. The "non-leaders (active)" category included individuals who held no official office, but who were active behind the scenes as volunteers, employees, committee members, etc. in Chinese 
community groups. "Non-leaders" were those who, while they may belong to some Chinese community groups, had no leadership position or any high level of activity in that group. It can be seen from Table I that eleven interviewees were in the "leader" category; three informants were non-leaders but active in the community; and five were non-leaders who were not particularly actiye in Chinese community affairs.

Our sample, therefore, cannot be considered completely representative of the Chinese community. We were, however, able to elicit much valuable data from our interviewees; and we observed a wide range of differing opinions, attitudes, and personal histories among our sample. Considering the limitations on time and resources involved in our study, we believe that our sample was as representative as possible.

\section{INTERVIEWING PROCEDURES}

The physical process of conducting the interviews was simple but adequate fpr our purposes. Potential interviewees were identified primarily by reputation; i.e., the author merely asked around about who might be a good person to talk to. We also made several visits to the Chinese Baptist Church (which is the largest Chinese church in town) and the CCBA building, and we met several of our informants at these places. Potential interviewees were sent a letter (included in Appendix A) which explained the purpose of the thesis and the interview process: These individuals were then contacted by phone and asked to participate in our study. Usually it 
was possible to set up an appointment immediately, although sometimes persistance. was required. Because of difficulties in setting up a mutually convenient time, we were unable to interview several of our potential informants.

All interviews were recorded on tape cassette, and roughly followed the interview schedule (also included in Appendix A) although the author tried not to be rigid in following this. The mean length of the interviews was 32.6 minutes, and ranḡed from fifteen minutes to one hour twentysix minutes. Obviously, some people had more to say than others. No formal statement was signed for release of information by the informant, but a verbal statement of consent was in each case obtained on the tape at the beginning of the interview.

Due to lack of funding, we were unable to transcribe the tapes, but we did make thorough notes on each interview from these tapes.

\section{RESPONSE TO INTERVIEWS}

We expected to meet some resistance, or at least reticence, on the part of the Chinese towards being interviewed. The writer is not Chinese -- which itself is a serious methodological defect in this study. One chinese researcher says :

Surprisingly, I did not encounter any direct refusal for an interview. (In several cases, there was initial reluctance until I made it evident that I was of the same ethnic background.) 4 
Various sources have stereotyped the Chinese as closemouthed, and unwilling to talk about their personal history or their problems with strangers. One Chinese writer who did a previous study in Portland observes that "The notion of being a research sample usually gives the impression of being 'exploited' in the chinese mind; hence their resistance to being studied." 5

The writer thus entered into the interview process with some trepidation. However, we found the people we talked with to be very friendly, open and cooperative. We felt that there was a desire on their part that people know more about them and understand better the nature of their community. We were refused interviews several times, but for what appeared to be genuine time commitments.

In addition to the interviews we conducted, we examined records of interviews conducted through the Oregon Historical Society. Charles DiGregorio did two interviews relevant to our study -- one with an elderly white woman who reminisced about the Chinese as she had seen them as a girl; and another with the first Chinese legislator in the Oregon Legislature. Chia-lin Chen wrote notes on nine interviews he conducted with prominent members of the Portland Chinese community. Both of these sources are listed in the bibliography. Thus, despite the methodological difficulties detailed above, and the small size of our sample, we were able to collect a great deal of oral data from a wide range of indiviquals in the Chinese community. 
${ }^{I}$ Laura Lum Sing, Wendy Po-kow Chan and Peter Tan-ping Wong, "Chinese Attitudes and Knowledge Concerning Social Services: A Survey of the Portland Chinese Community" (Master of Social Work practicum, Portland State University, 1973), p. 26.

${ }^{2}$ U.S. Department of Commerce, Bureau of the Census, 1970 Census of Population and Housing, Portland, Oregon Washington SMSA, (Washington: U.S. Department of Commerce, 1970), Table P-1, "General Characteristics of the Population: $1970 "$.

3ibid., Table P-3, "Labor Force Characteristics of the Population: 1970".

${ }^{4}$ Dean Lan, Prestige with Limitations: Realities of the Chinese-American Elite (San Francisco: R and E Research Associates), 1976, p. 62.

${ }^{5}$ Alex C.N. Leung, "Mental Illness Among Chinese in the United States: Myth or Reality?" (Masters thesis in Psychology, Portland State University, 1976), p. 2 . 


\section{PART I}

CULTURAL, POLITICAL AND ECONOMIC ANTECEDENTS

OF THE CHINESE EXPERIENCE IN THE UNITED STATES 
CHAPTER III

\section{CHINESE IMMIGRATION AND IMMIGRANTS}

\section{CHINESE SOCIETY IN THE NINETEENTH CENTURY}

Who were these Chinese immigrants who in the nineteenth century came to the American West Coast by the thousands? What motivated them to leave their families and travel half way around the world to a strange and often hostile wilderness country?

First, most of these immigrants came from Kwangtung Province in southern China; in particular from the area south of Canton and from Kwangchow Prefecture, which includes fourteen districts in the area immediately surrounding Canton. Two districts in particular -- Toi-shan and Hsin-ning -accounted for $60 \%$ of the nineteenth century immigration to the United States. ${ }^{1}$ Many of the Chinese in Portland came from Toi-shan, Ning-yang, or Hoy Yin. (On the following page we have provided a map of Kwangtung Province.)

\section{Social Structure}

To understand the motivations of the Chinese immigrants during the nineteenth century, we must understand the society and the conditions of life out of which these people came. The basis of nearly all aspects of Chinese life during this period can be found in the tenets of Confucianism. 


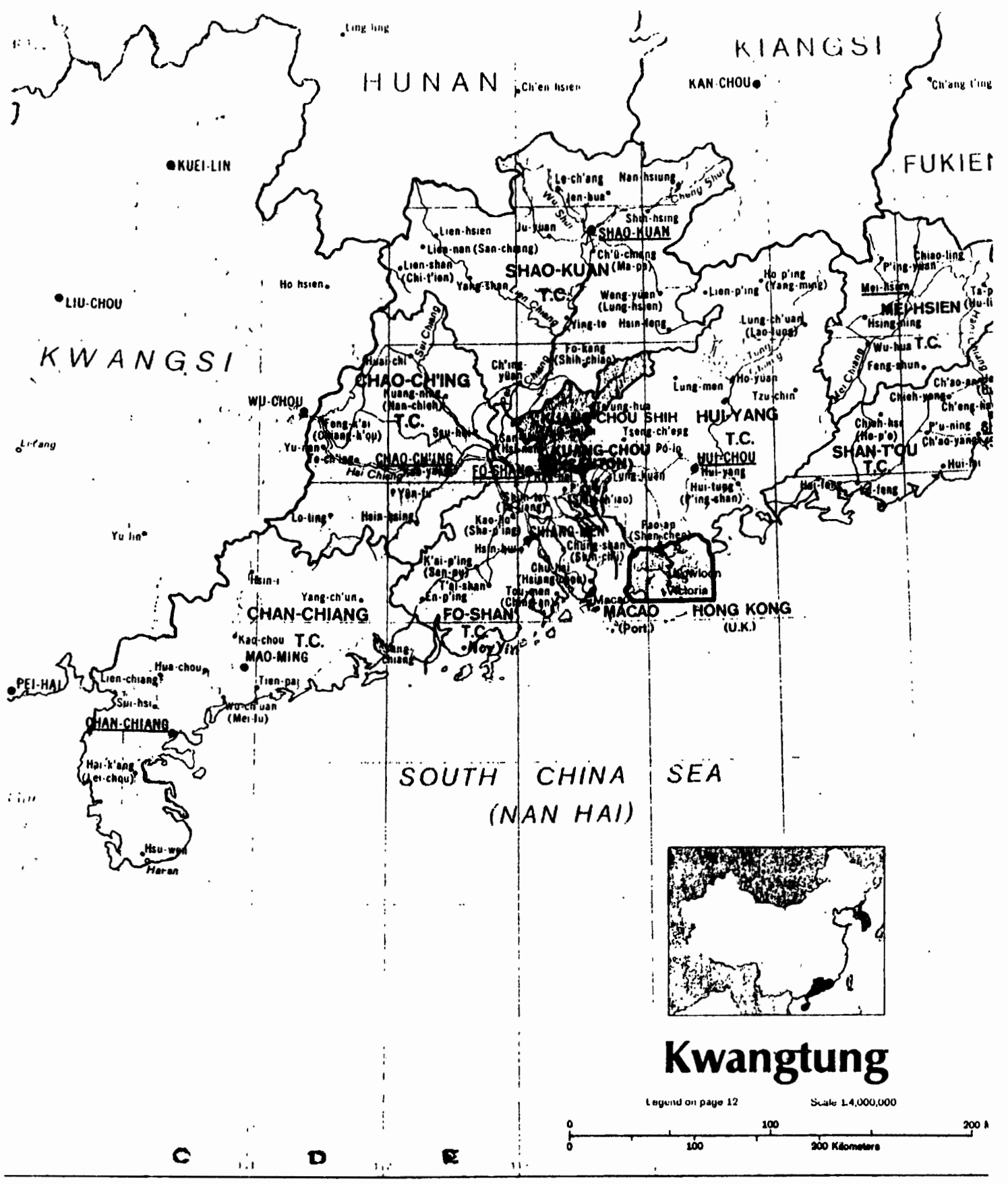

Ficure 2. Map of Kwangtung Province, China. 
Westerners sometimes think of Confucianism as a religion; and in a way it did have religious aspects to it -- there were Confucist temples, rituals, etc. But this was not its central role in Chinese society. Confucianism was in essence a philosophy concerning the ideal social structure; it was a system of ethics, law, government, and family life. One's relationship with and obligations to others was clearly defined. A hierarchal family structure, with rigid role relationships between parent and child, and husband and wife was mirrored by a governmental structure in which the Emperor fulfilled the role of father to the entire nation, and his subjects were expected to react to government with an attitude of filial piety. Melandy states that:

The government was likened to the village family with the Emperor the family leader. All owed a sense of loyalty to the Emperor, particularly his "adopted sons", those civil servants who held office because of him. 2

Confucianism was one leg of a "three-cornered stool" supporting traditional Chinese society, which also included Buddhism and Taoism. Though there was much overlap in the roles of these three philosophical traditions, in general Confucianism governed the social structure, Buddhism fulfilled the religious functions, and Taoism dealt with the relationship of man to nature. ${ }^{3}$

\section{Power Structure}

We have mentioned that the Emperor derived his authority from Confucist doctrine. In addition, we should mention that 
such doctrines also laid the basis for the class structure and bureaucratic organization of Chinese society.

A Confucist society is essentially a technocracy, in that positions of power go to the most learned. Wong observes that "Economic accruement and social status in traditional China were regulated by scholarly attainments." 4 A complex civil service examination system governed the distribution of positions in the bureaucracy. If one could pass one of these exams, which covered all areas of chinese literature and learning, a position in the government was assured. Passage of increasingly higher degrees through such examinations resulted in advancement to more powerful and prestigious positions. This was a meritocracy, and in a sense this was an egalitarian system; for jobs were passed out on the basis of learning, not social status or wealth. But in practice, of course, it was the rich, the nobility, and the land-owning gentry who were best able to educate their sons. There was no system of public education, although in the case of a poor but exceptionally brilliant student education was often provided through public subscription or a grant from one of the village gentry. Thus, while the civil service examination system did provide opportunities for advancement to extraordinary individuals in the lower classes, in general it assured that those already possessing wealth and prestige would be able to pass on their positions to younger generations. 
Such a system also guaranteed a conservatism, conformity, and rigidity of thought among the ruling elites. This was because the examinations were based on the classic Chinese works, which specified in detail the duties of the government bureaucrat, his relationship to his subordinates and his superiors, and even his ways of thinking.

\section{Class Structure}

Chinese society was thus dominated by a more or less strict class structure. Differences in status and life style depended not only on one's wealth, parentage, or scholarly ability, but on whether one was urban or rural. Government officials, gentry, nobility, and the favorites of the court obviously enjoyed the greatest power and benefits. A merchant or shopkeeper in the city did not have a great deal of prestige; but the status of the tenant farmers in the villages was even less; and the Tanka, or "boat people", held the lowest rung in society. There was also a division of status between the native inhabitants of Kwangtung, the "Punti", and the "Hakka", or "guests", who had migrated to South China from the north in the thirteenth century and were looked down upon by the Punti. ${ }^{5}$ It was the people of lower status -- the boat people, farmers, and occasionally, merchants -- who made up the emigrants to the United States.

\section{Family Structure}

But it was the structure of the family that formed the real basis of Chinese society in the nineteenth century. 
Wong states that

As the Confucian scholars demanded academic conformity, the traditional family pattern likewise in revealing its Confucian influences compelled the individual to seek security through conformity. 6

The Chinese family was not nuclear, but extended. Families traced their lineages back for generations, and the confucian ethic of filial piety led to the practice of ancestor worship. In many of the rural villages, the extended family structure had grown so much over the years that virtually the whole village was one family. Thus, many of these villages were organized around a clan structure. ${ }^{7}$ This is an important point, because in America many of these clan organizations were transplanted as "family associations". Portland has three such family associations in existence today; although in China, Hong Kong and Taiwan the clan has long since ceased to be an important social institution.

Besides having important social control functions, the extended family structure in the villages also had an economic function. The Confucian ethic stresses above all things the obligation of each individual to his family. The children support their aged parents, the parents work untiringly for the advancement of their children. Beyond this, because this is an extended family, even distant relatives or, in some cases, even individuals with the same surname, can seek refuge and assistance within the family. In a rural village based on subsistence farming, such a structure allowed a sharing of the work, and a sharing of the crops. 
This family structure also meant that it was essential that a family have sons. ${ }^{8}$ A son could help in the fields more than a daughter. A son could care for his aged parents (an essential consideration in a society where elderly people without sons to care for them might starve): A son could also carry on the family name, a crucial factor in light of the Confucian emphasis on filial piety and ancestor worship discussed above; for without descendents, there would be no one to make offerings in one's memory in centuries to come.

Chinese society was thus highly male-oriented. Women had an extremely low place in this structure. Also, the senior female of the household ruled the other women despotically, so that a woman could not hope for any degree of self-determination or leisure, even in the setting of the home, until reaching old age. A man could dismiss his wife for any reason (often because of his parents' displeasure or because of her failure to bear sons). A woman could not leave the home without her husband; one of her primary duties was waiting on her parents-in-law and raising the children. ${ }^{9}$ This was one reason why men did not bring their wives with them when they emigrated to America; it was socially unacceptable. (There were, of course, other reasons, which will be further discussed later -- lack of money to bring the whole family and, after the advent of exclusion laws, legal prohibitions on bringing one's wife and family to the United States.) 
Social Restraints on Emigration

But there were social and legal restraints on the emigration of men, also. Prior to 1859 , it was illegal, on penalty of death, to emigrate from China. This law had been originally formulated in 1656, at the beginning of the Ch'ing Dynasty, to prevent Ming Dynasty sympathizers from fleeing to Formosa. But by the nineteenth century this law was largely a dead letter. 10

Social expectations were also operative. Chen states that

Except for great natural forces such as famine and death, or some extraordinarily significant plan for education or business, men usually preferred to stay at home. Departure from family and travel outside was considered as the greatest of unhappy events.1.1

Thus, a person sought work abroad only when he could not care for his family at home; fulfilling one's family obligations was the primary consideration. Also, there was a great fear of dying away from home. If one was buried overseas, the family could not care for the grave or make offerings to it on appropriate holidays. This in part explains the desire of most Chinese immigrants to return to China to die, or at least have their bones returned. ${ }^{12}$ Shipping bones of deceased Chinese back to their hometowns was an important function of many Chinese organizations in America. As late as 1948, the Chinese Consolidated Benevolent Association in Portland made such a shipment. 
Conditions in Nineteenth Century China

Despite the social unacceptability of travel, conditions in southern China in the late nineteenth century were such that many individuals had no choice but to emigrate or die. Natural catastrophes resulting in famine occurred every few years. Edson observes that

Although Kwangtung Province is a naturally fertile and prosperous agricultural area, supporting crops of rice, vegetables, and fruit, it was also subject to numerous typhoons, floods, and subsequent famines.13

The root of these problems can probably be found in the extremely high population density of South"China. A family of five needed 1.7 acres to support itself in southern China, but $55 \%$ of the farms were less than one-half acre in size. The population density varied from 980 to 6880 in the village districts. Under such conditions, the land could barely support the population even in a good year, and no food reserves could be collected. Thus, while the immediate cause of the frequent famines in southern China were natural catastrophes, the population problem was the fundamental cause. 14

Political unrest also resulted in much loss of life, destruction of crops, and social disruption in the southern China of the nineteenth century. The Ch'ing Dynasty, which ruled China at that time, was dominated by Manchurians, from northern China. Many of the provincial officials in the south were not natives of the areas they governed, and besides were noblemen with little understanding for the problems of the village peasantry. 
China was in a state of unrest. Barth says that "Secret societies recruited farmers and fought pitched battles for control of the countryside." 15 The most important of these societies was the Triad Society, a revolutionary group dedicated to the overthrow of the Manchus, which for a brief period in the middle of the $1800^{\prime} \mathrm{s}$ controlled Canton. ${ }^{16}$ It resurfaced in America, in a greatly changed form, as the Bing Kung-Bow Leong Tong, the so-called "Chinese Masons". Many of the tongs in America had their roots in such revolutionary secret societies in China. Other secret societies were involved in the traditional animosity, resulting in periodic outbreaks of violence, between the Punti and Hakka. ${ }^{17}$ Several major uprisings occurred in the 1840's and 50's. The Taiping Rebellion, 1850-1864, resulted in the death of twenty million people in southern China. 18

Western encroachments on Chinese sovereignty (to be discussed in more detail in the next chapter) also added to the general atmosphere of social and political upheaval. The Opium Wars of the 1840's were centered mostly around Canton, and resulted in the institution of treaty ports, of which Canton was one, under foreign domination. Hong Kong and Macao, both formerly in Kwangtung Province, were ceded out'right to the Westerners. Canton had been the major trade center of China, and the only port for foreign trade, prior to these foreign interventions. Thus, the reorganization of trade resulting from the Western incursions disrupted the life of the Canton merchantmen. ${ }^{19}$ The Opium Wars also 
resulted in huge indemnities, which were paid largely with the taxes of the peasants.

Thus, as Barth summarizes it,

Dynastic decline, political corruption, inadequate administration, Chinese resentment against the alien Manchu overlords, secret societies, agrarian distress, population pressure, rebellions, and foreign penetration created a dilemma in which defeats in any one area of conflict increased the difficulties in all the others. 20

The stability created by the strong family structure and the Confucist ethic was being battered severely. Only in recent years has life begun to settle down again in southern china. In the nineteenth century, many saw emigration to America as a way out of an impossible situation at home, and a way to provide for their families by making money and sending it back to China.

\section{CHARACTERISTICS OF CHINESE IMMIGRANTS}

We have stated that the chinese immigrants came from the least prestigious classes in China -- primarily farmers and a few merchants. Although they were from the lower classes, it should be emphasized that they were not the vicious, thieving, uneducated rabble that anti-Chinese agitators made them out to be. Most were literate and, in comparison to the general character of the Western frontiersmen at that time, highly civilized and cultured. Coolidge points out that the immigrants, in order to come to America, at least needed security for a ticket, so they were therefore not drawn from "the helpless and vicious", but from "free agricultural 
peasantry". 21

Most of these peasants became laborers in the states, and some merchants also emigrated to continue their trade in America. Tsai says, "It is interesting that the merchants, who ranked near the bottom of the Chinese social scale, were leaders among the Chinese in the United States."22 Many laborers who made some money and, for one reason or another, remained in the United States, eventually were able to open shops or restaurants and become merchants themselves.

\section{The Immigrant as Sojourner}

We have emphasized that these Chinese came as sojourners. They never intended to remain here, and few learned to speak English at all fluently. Fewer still showed any interest in learning about American institutions and culture. They were, in fact, barred from becoming American citizens until 1943.

We have seen that most desired to return home as soon as they could acquire some money, or at least before they died. Their families also applied as much pressure as they could to ensure an early return to China. Chia-lin Chen, in his thesis, "A Gold Dream in the Blue Mountains", about the Chinese miners in the John Day area in the nineteenth century, provides an appendix of his translations of twenty-four letters between these miners and their families in China. ${ }^{23}$ These letters are a valuable and unique source of information, in the words of the Chinese sojourners themselves, 
about their feelings and motivations. Almost every letter from the immigrants' families includes a plaintive plea to return home as soon as possible. A few of these passages are included below:

I hope you will be home and get married while I am alive, so that I might die with my eyes closed and without grievance... You should save some money and should come back at least next year. I know my days are numbered. You won't see me any more; I may already be gone by the time when you come back. Would you feel sorry then?

--from a mother in China, $1898 .^{24}$

Come home as soon as you can. Don't say "no" to me any more. There are too many gossips in our village that make me uneasy. You are my only son. You have no brothers, and your age is near forty but still without a male offspring. You should think carefully. If you neither make a fortune abroad nor have a son at home, your loss is double. So why not come home before it is too late?

--from a father in China, 1899.25

If you have any soul, come home immediately. --from an uncle in China, 1906.26

These excerpts vividy illustrate the strong family feeling that we talked about earlier. But many Chinese were unable to return; and a few built prosperous businesses or became Americanized to the extent that they did not want to return.

Chinese testified before a Congressional committee in 1876 that few of them could save the money necessary for the return trip. 27 And the scott Act in 1888 made it impossible for a laborer to return to the United States after a visit to China. Even many Chinese who were eligible to re-enter 
the U.S. (such as merchants) were submitted to long periods of detention by immigration officials. Thus, visiting one's home was virtually impossible, and returning there permanently was often difficult.

Immigrants as an All-Male Society

In discussing the character of the chinese immigrants, we must remember that they were almost all male. Some had families of their own in China, but most were bachelors. In Eastern Oregon in 1870, there were only forty-three females ( $2 \%$ of the total Chinese population), and in 1880 only fortyseven females $(1 \%)$. Most of these females were prostitutes. 28 In 1910 the male-female ratio for chinese in the United States was $14: 1$, and in 1930 it was still $4: 1 .^{29}$

Portland, which around the turn of the century had the second largest Chinese population of any American city, in 1910 had a male-female ratio for Chinese of 25:1. But by 1930 this fell to $2.3: 1 .^{30}$ Thus, it appears that a more normal family life was made possible earlier. in Portland than elsewhere in America, but that even here a shortage of females continued well into recent times. In any case, the Portland of the 1800's had an only slightly better malefemale ratio than the mining areas in the eastern part of the state. In $1870,92.6 \%$ of the Chinese population in Portland for whom we have data on sex and marital status was male. of 315 males and 25 females, only five of each sex were married. It can be assumed that most of the remaining twenty 
females were prostitutes. By 1880 this situation had improved only slightly. Of 786 Chinese, 724 (92.1\%) were male. 289 were married, most presumedly to women in China, for of the 62 females, only 54 were married. 31

It should be pointed out, however, that there was a shortage of women in the nineteenth century West among the white population as well. The same study cited above shows that the general population of Portland was $64.0 \%$ male in 1870 and $64.4 \%$ male in $1880 . .^{32}$

Restrictions on Having a Family

Many Chinese undoubtedly would have liked to have brought their families to America with them, but several factors restricted their ability to do so.

First, few Chinese had the money to bring their family here. The Nees quote an elderly bachelor Chinese in San Francisco:

In those days, one thing about chinese men in America was you had to be either a merchant or a big gambler, have a lot of side money, to have a family here. A workingman, an ordinary man, just can't!.33

Another factor was the hostile atmosphere in which the Chinese here often lived. Bessie Ying Lee quotes a Portland Chinese:

I did want to bring my wife with me when I made my second trip, but everything was so uncertain here, on account of a strong anti-Chinese movement. 34

Other reasons are implied in the statement of another Chinese man quoted by Lee: 
I couldn't very well bring the whole family along because my wife was obliged to stay at home to take care of my parents. Besides, when I. first came I intended to return in a few years. Now it is too late to bring my wife to this country. 35

One of the reasons it was "too late" was a law passed by the U.S. Congress in 1924 prohibiting Chinese women from entering the United States, even if they had husbands or children who were American-born citizens or legal permanent residents.

Thus, the Chinese community was basically a womanless society well into the twentieth century. This is a key fact in understanding the early history of this community. Lack of a family life, especially to individuals for whom the family was so important, constituted a very severe restraint on the continuation of the familiar life-style and cultural patterns of these Chinese. This social disruption resulted in a proliferation of various vices in the Chinese community, which the whites at the time misinterpreted as being due to Chinese racial characteristics.

Frequenting of prostitutes was one such practice which we have already alluded to. When we consider the circumstances, the widespread prostitution in Chinatown in the nineteenth century seems not only uncensurable, but inevitable and necessary.

Drug use, in the form of opium, was also widespread among American Chinese. Opium had been introduced to China by the British in the 1830's, but we assume that its use was not nearly as widespread there as among the chinese in the 
United States. It was cheap, legal, readily available from any Chinese store (and sometimes provided by employers); and it helped relieve the tension and harshness of the life of the Chinese laborers:

Gambling was another vice almost universal among the early Chinese immigrants. Chen says that it was also endemic in China, and had since early times been "a popular. 'national game'" which "was an antidote to the rigidness of Chinese culture." 36 In America, the chance of sudden wealth offered by gambling, the opportunity to be one's own man, and the chance to relax among friends made gambling an extremely popular pastime among Chinese. Gambling raids were conducted in what used to be the Portland Chinatown as late as 1975,37 but the practice was at its height in the 1800's and early 1900's.

Characteristics of the Immigrants

Chinese were also observed to exhibit certain personality characteristics in the early days of Chinese immigration. They were said to be hard workers, and to be obedient and uncomplaining. They seldom fought back against the frequent insults and physical attacks by whites. But in actuality the Chinese were not really docile; they simply had no choice. Chen summarizes the situation well:

The savagery and the cruelty of the frontiersmen made the Chinese believe that they were living among real barbarians, both whites and reds. Their bodies were smaller. They did not have weapons. Above all, they were unprotected by law. Therefore they were always compelled to submit-- the only alternative available to them! They were cowards as some Americans asserted. 
But viewed from another side, they were the bravest! Breaking all shackles of culture, religion, language and emotion, they came to the Gold Mountains in an attempt to relieve their families of eçonomic difficulty, at the risk of their own lives. ${ }^{3}$

MOTIVATIONS OF THE CHINESE IMMIGRANTS

Migrations and movements of Chinese were not unknown throughout history. Chen cites four large scale movements during the Ming dynasty; and also mentions an annual migration of farmers from Shantung to Manchuria. ${ }^{39}$ He says that Chinese were generally known as a people unwilling to leave their homes for other lands. But on the other hand, when their very existence was jeopardized, Chinese would also throw themselves into dynamic migration movements, and even emigrated to other countries. 40

The nineteenth century was such a time of jeopardy for the Chinese in southern China. We earlier documented the situation in China during this period; the purpose of this section is to review some direct accounts of the motivations of the immigrants in coming to America.

Theories on Motivations of the Immigrants

There are various theories about the motivations of the Chinese immigrants. We have thus far documented the fact that many Chinese had no alternative but to emigrate; internal wars, oppression by foreigners, and frequent famines caused by population pressures created an unbearable situation at home. Chinese were thus motivated to find wealth abroad so that their families at home might survive. Chen presents this as the primary reason for emigration; ${ }^{41}$ and it 
is mentioned as a key motivation by many other writers. But it was certainly not the only factor involved in this movement.

The California gold rush of 1849 marked the start of the migration; and many Chinese came to America as miners. Barth writes:

...the gold fever of the Pearl River Delta stimulated Chinese attempts to learn more about California life. It produced not only a local gold rush into hills around Canton, but also a demand for broadsides and maps describing the chances of success in the California Golden Mountain. 42

Barth, in fact, seems to feel that the Chinese immi-. grants were motivated primarily by greed, raţher than necessity. They wished to get all the money they could, and return to their homes in honor and splendor. ${ }^{4}$ In light of our previous discussions of the situation in China, we must reject this factor as the central motivation, although the hope for advancement was certainly a secondary motivation for many immigrants.

Americans themselves were responsible for motivating and facilitating much Chinese immigration. Tsai cites contemporary historians in the People's Republic of China as saying that the immigration was solely a result of American desire for cheap and docile labor on the West coast. 44 There is evidence that at times Americans were responsible for bringing Chinese in for this purpose. When the transcontinental railroad was being built, arrangements were made to import thousands of Chinese laborers. Also, American shipping 
companies were very involved in promoting Chinese immigration. Chen makes the point that:

Because of the impassable ocean, the adventure of the laborers and peasants would never have come about had not the Americans been interested in employing them. Shipmasters quickly seized upon the situation, distributing placards, maps, and pamphlets concerning the Gold Mountains [America] .45

But to say that this was the sole cause of the Chinese immigration movement is an oversimplification.

There is little evidence that desire for American citizenship or for "the American way of life" motivated many of these early immigrants. They were, as we have said, barred from citizenship, and regarded Americans as a rough and uncultured people. This view has nevertheless been advocated by some writers. Viola Noon Currier, in a passage typical of the ethnocentric and ostentatious tone of her thesis, says :

Ideas of America had probably slumbered for years like larvae in a cocoon, for the mind of China arouses slowly and requires a strong impetus to awake it to action. 46

\section{Accounts by Immigrants of Their Motivations}

Most of the writers cited above based their ideas on records and materials left by white Americans of the period; it is difficult to find an account of chinese immigration written by the Chinese immigrants themselves. Again, the letters found by Chia-1in Chen in the Kam Wah Chung Co. building in John Day provide us with valuable data. In an angry letter dated June 16, 1897 from Ing Wen-teh to Ing 
Pang-chi, accusing Pang-chi of appropriating some of Wenteh's money, the writer says:

I came to America to labor, to suffer, floating from one place to another, persecuted by the whites, for more than twenty years. What is my goal for enduring this kind of pain and hardship? Nothing but trying to earn some money to relieve the poverty of my home. Do you know that both the old and the young at my home are awaiting me to deliver them out of starvation and cold? 47

And from a man who had returned to China from America:

I have been unemployed at home since I left America. To sit and waste food is what I can do now. This is so disastrous that even a mountain of gold would be used up. Therefore, I am planning to go back to the United States again, to see if there is a chance for me. 48

The hope of the immigrants to advance their position is demonstrated in Chen's account of an interview with Charles Leong, who spoke of his father, Leong Hong. Chen paraphrases this statement about the father's reason for coming to America: "Being a son of a second wife, there was not chance nor family privelege for him, so he came to the United states when he was seventeen or eighteen years of age." 49 And the Nees quoted an elderly Chinese in San Francisco as saying: "From one generation to another, everybody tries to send a man overseas. That's the only way you can make things better." 50

\section{METHODS OF IMMIGRATION}

There is some controversy over the way in which the Chinese came to America. While most writers say that this - immigration was a voluntary process, some others claim that 
Chinese were forced to come here, or came under a system of debt servitude.

In any case, the Chinese came on Western ships, usually American, which in the late $1840^{\prime} \mathrm{s}$ and $1850^{\prime} \mathrm{s}$ made the trip in fifty-five to sixty-five days. By the late 1860's; the introduction of steamers cut the time down to thirty or thirty-five days. ${ }^{51}$ The fare in the 1850's was from forty to fifty dollars. 52

The Case for Involuntary Immigration

Of the studies of which we are aware, Barth, in Bitter Strength, makes the most complete case for the idea that Chinese immigration was involuntary. This is, in fact, a major theme of his book. He explains his interpretation of the "credit-ticket system":

Indentured emigrants relied on the credit-ticket system under which they obtained their passage from Chinese merchants [in America] who were reimbursed by relatives of the travelers or by their future employers. In return, the newcomers worked for whoever extended the credit until the debt was paid... The system camouflaged a debt bondage that turned indentured emigrants into slaves of their countrymen who ruled through influences unfamiliar to outside observers. 53

Barth makes it clear that the "Chinese merchants" and "countrymen" that enslaved the immigrants operated through the Six Companies, the major Chinese organization in San Francisco. The analogous organization in Portland is the Chinese Consolidated Benevolent Association. We reject the idea that the primary function of such organizations was the control or enslavement of Chinese labor; and we will discuss 
the functions of these organizations more fully in the chapters to come. What we are concerned with here, however, is the idea that the credit-ticket system (i.e., buying passage to America on credit) was a form of indentured servitude. We feel that this idea, too, is false; although some instances of contract labor undoubtedly occurred among the Chinese in America.

The theory that Chinese labor was kidnapped or forced in some way to come to America is not exclusively Barth's opinion, but is also common among many radical historians. Tsai cites a Communist Chinese historian, Liu Ta-nien, as saying :

America capitalists were aware of the fact that Chinese labor was cheap. Therefore, they used all kinds of fraud and propaganda to bring the chinese laborers to the United States. 5

Also, I Wor Kuen, a revolutionary Asian-American organization in San Francisco, wrote in its newsletter, Getting Together:

The "credit-ticket" system was a modified form of slave trade... What actually resulted was a system of contract labor whereby the broker and the American companies collaborated to exploit the immigrant to the utmost. Passage rates were set so high that the immigrant usually had to work for a few years in order to pay off the broker. 55

\section{The Case Against Forced Immigration}

But we have seen that fares for passage were in the forty to fifty dollar range. Even assuming that unscrupulous shipmasters would find ways of levying extra charges on the Chinese during passage (as Barth claims), and considering the 
wage scales of the time, we believe that most Chinese could pay off this debt in well less than a year. The chinese were undoubtedly victimized by whites in many ways, but we don't think this was the case here:

There is evidence that contract or indentured labor was brought from China in certain instances, though it appears that the great majority of Chinese immigrants were not contract laborers. Melendy says that a contract labor system was briefly attempted around 1850.56 And it is a matter of record that the builders of the transcontinental railroad conducted a campaign to recruit and transport laborers from China, though exactly how many were thus brought to America is unknown. 57

Contract labor was not the general rule on the West coast, however. In fact, the California legislature, in 1852, rejected a law which would have legalized contract labor. 58

It should be pointed out that Americans were involved in what amounted to a "slave trade" in Chinese indentured laborers in South America. Chinese were lured to the boats in Hong Kong or Canton through false promises, forcible kidnapping, gambling, or capture in clan fighting. Conditions aboard these ships, which were mostly American, were horrid. Many Chinese committed suicide during the passage, and there were several cases of mutiny. On arrival in China or Peru, which were the main centers of this "coolie trade", Chinese were brutalized, and were often bought and sold through 
American brokers. Tsai claims that of one hundred and fifty thousand coolies taken to South America before 1865, less than five hundred ever returned to China alive. 59

In 1847 and 1849 laws had been passed preventing such traffic to the United States, but it was not until 1862 that a law was passed prohibiting the involvement of American ships in the "coolie traffic" to South America. 60

Despite Barth's argument, the majority opinion in the literature seems to be that the credit-ticket system of Chinese immigration to America was a form of free immigration.

\section{Specific Inaccuracies in Barth's Thesis}

Barth's argument includes several statements which, while they may not be deliberate falsehoods, at least indicate misrepresentation or ignorance of the facts. For instance, speaking of the credit-ticket system and its relation to indentured labor, he says:

In 1877 , a congressional committee's report furnished evidence about the operations of the system in the $1860^{\prime} \mathrm{s}$ and 1870's. The testimony may have been partisan in interpretation. But neither the defenders nor the foes of indentured immigrants questioned the existence of the pattern. 61

The investigation was undoubtedly partisan, because it was a result of a building anti-Chinese movement in America. But two pamphlets distributed at the time quoted testimony from these hearings favorable to the Chinese, and some of these statements emphasize the voluntary nature of chinese immigration. 
In fact, the minority report of the Committee, written by Senator Oliver P. Morton, says:

The evidence established the fact that Chinese labor in California is as free as any other. They all come as free men and are their own masters absolutely. In many cases they borrow their passage money in China, with an agreement to repay from their earnings in this country with large interest, an agreement which to their credit be it said, they rarely fail to perform. ${ }^{62}$

A California state legislative committee in 1862 reached similar conclusions. ${ }^{63}$ But another state committee in 1876 reported that, of the Chinese laborers, "Ninety-nine onehundredths of them are imported here... to all intents are serfs." 64 This committee was, for political reasons, more hostile to the Chinese than either of the others mentioned. But it still included testimony to the effect that Chinese were free laborers. S. Wells Williams, Secretary of the U.S. Legation to China, said that "I know nothing of the existence of any contracts made in China by which emigrants are shipped to America."65 And Rev. A.W. Loomis, former missionary to China and, at the time of the hearings, home missionary to the Chinese in San Francisco, testified that "There are no coolies brought to California, nor do the six companies import their countrymen at all. All Chinese male emigrants to California are free." 66

In discussing these hearings the question becomes a matter of which witnesses one chooses to believe. It should be noted that the witnesses cited above, with the possible exception of Senator Morton, were among the most knowledgeable white men of the time regarding the Chinese immigrants, 
and had little personal or political self-interest in the question. In any case, Barth is obviously wrong when he bays that "neither the friends nor the foes of indentured immigrants questioned the existence of the pattern."

Methods of Financing Immigration

Most contemporary authors are of the opinion that, as Edson puts it, "The majority of evidence suggests that the Chinese immigrant was a free laborer and not an indentured slave."67 The question remains as to how the Chinese actually financed their voyages to the United States, if not by indenturing themselves. Tsai says:

Chinese emigrants obtained the money to pay their passage in various ways. Some had saved money, others sold their property, including land or hogs to secure passage. Some borrowed money from friends or relatives. Some pledged families as security for the loan. They came at their own option, and when they arrived in California they were free to go where they pleased and engage in any occupation they liked. 68

This writer believes that the evidence is on the side of Tsai's theory; but it is impossible at this late date to get conclusive data on the question. Chen does, again, describe one direct account of how a would-be Chinese emigrant tried to get the money for passage, in this excerpt from a 1903 letter from a man in China to his cousin in John Day:

... I am unable to take any option, for I cannot afford the fare for passage, nor can I find a source from which to borrow. Furthermore, I don't have any brother abroad to render me the needed assistance. There seems no way for me to escape this country. 69

This letter implies that by 1903 indenturing was not thought of as a possible way to get to America, but it of 
course says nothing about conditions that might have existed earlier.

We conclude, however, that most if not all chinese immigrants to the United States in the nineteenth century came of their own free will (although they may have been influenced by the promotions of the American shipping lines); and that they were free upon arrival to choose their area of employment (although they may have been somewhat in debt for their passage fare).

In the next chapter, we look at the diplomatic relations between America and China, and the many ways in which this influenced the treatment of the Chinese in the United States. 
CHAPTER III: FOOTNOTES

${ }^{1}$ Shih-Shan Henry Tsai, "Reaction to Exclusion: Ch'ing Attitudes toward Overseas Chinese in the United States, 18481906" (Ph.D. dissertation in History, University of Oregon, June, 1970) pp. 96-97.

2 H. Brett Melendy, The Oriental Americans, (N.Y.: Twayne Publishers, Inc., 1972) p. 7 .

${ }^{3}$ For more information on the philosophical bases of Chinese society, see Arthur Waley, Three Ways of Thought in Ancient China, (Garden City, N.Y.:Doubleday and Co., Inc., 1939).

${ }^{4}$ James I. Wong, Aspirations and Frustrations of the Chinese Youth in the San Francisco Bay Area: Aspersions Upon the Societal Scheme, (San Francisco:R and E Research Associates, 1977) p. 36 .

${ }^{5}$ Gunther Barth, Bitter Strength: A History of the Chinese in the United States, 1850-1870, (Cambridge, Mass.: Harvard University Press, 1964) pp. 21-25.

${ }^{6}$ Wong, p. 37 .

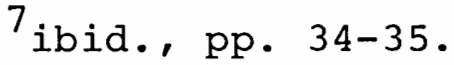

${ }^{8}$ Melendy, p. 5 .

${ }^{9}$ Chia-lin Chen, "A Gold Dream in the Blue Mountains; A Study of the Chinese Immigrants in the John Day Area, Oregon, 1870-1910" (Masters thesis in History, Portland State University, 1972) pp. 3-4.

$10_{\text {Tsai, pp. } 68-71 .}$

$11_{\text {ibid. }}$ p. 7 .

12 ibid. , p. 9.

${ }^{13}$ Christopher Howard Edson, The Chinese in Eastern Oregon, 1860-1890, (San Francisco:R and E Research Associates, 1974) p. 5 . 
${ }^{14}$ Chen, pp. 16-17.

${ }^{15}$ Barth, p. 24 .

16 ibid.

17 ibid., p. 25.

${ }^{18}$ Chen, p. 18; and Edson, p. 6 .

${ }^{19}$ Chen, pp. 22-23; and Edson, p. 5.

20 Barth, p. 27.

${ }^{21}$ Mary Roberts Coolidge, Chinese Immigration, (N.Y.: Henry Holt and Co., 1909; reprint ed., N.Y.:Arno Press and The New York Times, 1969), pp. 19-20.

22 Tsai, p. 101

${ }^{23}$ Chen, Appendix A, pp. 141-168.

24 ibid., p. 144.

$25_{\text {ibid., p. } 145 .}$

26 ibid., p. 148 .

27 Melendy, p. 21.

${ }^{28}$ Edson, pp. 58-60.

${ }^{29}$ Shien Woo Kung, Chinese in American Life, (Seattle: University of Washington Press, 1962), p. 33, Table I.

${ }^{30}$ Bessie Ying Lee, "Perpetuation of Primary Group Patterns Among the Chinese in Portland, Oregon" (Masters thesis in Sociology, University of Oregon, June, 1938); p. 39.

${ }^{31}$ John B. Dalton, "Marriage, Ethnicity and Persistance in Portland, Oregon, 1860-1880", (Bachelor's thesis in American Studies, Reed College, May, 1972), pp. 26-28. Apparently Dalton's statistics only cover those Chinese for whom he could identify marital status, for it certainly does not 
cover the entire Chinese population in Portland for this time period.

32 ibid.

${ }^{33}$ Victor G. and Brett De Bary Nee, Longtime Californ': A Documentary Study of an American Chinatown, (N.Y.:Pantheon Books, 1973) p. 18 .

34 Lee, p. 37.

35 ibid.

${ }^{36}$ Chen, pp. $14-15$.

37 "Tax Agents Seige Books of Three Chinese Tongs", Oregonian, July 11,1975, p. Al8, c. 6-8.

38

Chen, p. 10 .

${ }^{39}$ ibid., p. 134 and p. 71.

40 ibid., p. 134 .

$41_{\text {ibid. }}$ p. 22 .

42 Barth, p. 158 .

43 ibid., p. 1 and pp. 29-30. In future pages we will see that Barth frequently takes viewpoints derogatory to the Chinese character, although he is often cited as an authoritative source on Chinese in the United States. The Nees say of Barth's book, Bitter Strength: "A deliberate obfuscation of the nature of the American response to nineteenth century Chinese immigration makes Barth's work racist history." (Nee, Longtime Californ', p. 5n.): We agree with this assessment and while we will make use of factual data in Barth's book, we will also, where appropriate, point out his misinterpretations.

$$
\begin{aligned}
& 44 \text { Tsai, p. } 93 . \\
& { }^{45} \text { Chen, p. } 25 .
\end{aligned}
$$


${ }^{46}$ Viola Noon Currier, "The Chinese Web in Oregon History", (Masters thesis, University of Oregon, June, 1928), p. 15. Currier provides some useful data in her thesis, but, as Chen observes in his "Selected Bibliography of the Chinese in the West" (p. 10), "Currier maintained a theme that the Chinese were inately different from other men, a difference that connoted inferiority." Also, her thesis is marred by metaphors and syntax that is often ludicrous, as in "Congress and the President were carefully treading along the pitfalls of international abysses..." (Currier, p. 50).

${ }^{47}$ Chia-lin Chen, "The Kam Wah Chung Company Papers. John Day, Oregon", (unpublished manuscript, Oregon Historical Society., 1974), p. 128 .

${ }^{48}$ Chen, "A Gold Dream in the Blue Mountains", p. 152.

${ }^{49}$ Chia-lin Chen, "Interviews with Some Prominent Members of the Portland Chinese Community", (unpublished manuscript, Oregon Historical Society, 1973) p. 18.

50 Nee, p. 17 .

${ }^{51}$ Barth, pp. 58-59.

52 ibid., pp. 61-62.

53 ibid., p. 51 .

54 Shih-Shan H. Tsai, "Chinese Immigration through Communist Chinese Eyes: An Introduction to the Historiography", in The Asian American: The Historical Experience, Norris Hundley, Jr., editor, (Santa Barbara:Clio Press, Inc., 1976), p. 61 .

${ }^{55}$ I Wor Kuen, Chinese-American Workers: Past and Present -- an Anthology of Getting Together, (San Francisco: I Wor Kuen, [1973?]) p. 3.

${ }^{56}$ Melendy, p. 16 .

57 Barth, pp. 117-118; Nee, p. 40; and Alexander Saxton, The Indispensible Enemy; Labor and the Anti-Chinese Movement in California, (Berkeley:University of California Press, 1971), p. 65. 
${ }^{58}$ Melendy, pp. 16-17; and Tsai, "Reaction to Exclusion", p. 48 .

59 Tsai, "Reaction to Exclusion", pp. 52-58. See also Melendy, p. 13; Kung, p. 18; and Coolidge, p. 44.

$60_{\text {Tsai, }}$ Reaction to Exclusion", p. 49 and p. 88.

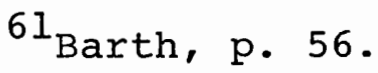

${ }^{62}$ Frederick A. Bee, The Other Side of the Chinese Question - - Testimony of California's Leading Citizens, (San Francisco:Woodward and Co., Printers, 1888; reprint ed., San Francisco:R and E Research Associates, 1971) p. 17.

63 ibid. ; p. 16.

${ }^{64}$ Six Chinese Companies, Memorial; An Address to the Senate and House of Representatives of the United States, (San Francisco: Six Chinese Companies, 1877; reprint e,., San Francisco:R and E Research Associates, 1970), p. 3.

$65_{\text {ibid. }}$

${ }^{66}$ ibid., p. 4.

67 Edson, p. 23.

${ }^{68}$ Tsai, "Reaction to Exclusion", p. 99. See also Coolidge, p. 43.

${ }^{69}$ Chen, "A Gold Dream in the Blue Mountains", p. 163. 
CHAPTER IV

CHINESE-AMERICAN RELATIONS DURING THE PERIOD OF CHINESE IMMIGRATION

\section{INTRODUCTION}

In this chapter, we will review the history of ChineseAmerican diplomatic relations pertaining to Chinese immigration to the United States. We have seen that the greatest portion of Chinese immigration occurred in the nineteenth century, from the 1840's until the imposition of exclusion legislation in the $1880^{\prime} \mathrm{s}$. Much of the current ChineseAmerican population in the United States is derived from this early wave of immigration. Our purpose in this chapter is to show that the relationship between the United States and China during this period affected the condition of the Chinese immigrants here to a great extent. China, especially the coastal areas such as Kwangtung Province, from which most immigrants came, was in an almost colonial relationship vis$a-v i s$ the Western powers in the nineteenth century; and as a result of this the status of the chinese immigrants in the United States can be seen as that of a colonized minority. We have been aided in formulating some criteria to identify and define a "colonized minority group" by Robert Blauner's book, Racial Oppression in America. ${ }^{1}$ A doctoral dissertation by Shih-Shan Henry Tsai, "Reaction to Exclusion: Ch'ing 
Attitudes Toward Overseas Chinese in the United States, 1848$1906^{2}$ was very useful in untangling the many complex aspects of Chinese-American relations during the nineteenth century.

THE DIPLOMATIC STRUCTURE IN CHINA IN THE NINETEENTH CENTURY

Chinese Attitudes Towards Foreigners

The Chinese have traditionally regarded their country as the center of the world. One Chinese name for China, 中國 (chung-kuo), in fact means "central nation or people". (This name for China is often, but imprecisely, translated as "The Middle Kingdom".) The predominance of China in the history of the Far East had in the early nineteenth century led to an attitude that regarded all foreigners as uncultured barbarians, hardly worthy of the attention of the Ch'ing Dynasty. As Coolidge puts it,

The enormous extent and predominance of the chinese Empire in the Orient and the isolation of its population for many centuries has bred an extraordinary and-to the Westerner--insufferable pride in the behavior of the chinese toward foreigners. 3

Therefore, before the Opium Wars the Chinese Empire recognized no foreign power as an equal; and in fact delegated many diplomatic negotiations to provincial authorities. 4

The Opium Wars, and events following, roughly disabused the Chinese of their notions of predominance; but the attitudes towards foreigners based on these notions were at times not so easily discarded. Chinese attitudes towards foreigners at times influenced American treatment of the Chinese immigrants. For instance, in an 1852 debate on Chinese 
contract labor in the California state Senate, Senator Phillip Roach argued that while most countries granted reciprocal rights to Americans, in China "we are not permitted to enter within their walls." 5 and currier is of the opinion that

England has always been censured for the Opium War of 1840 but the underlying cause of this war can be found in the treatment accorded Lord Napier [a British envoy forced to "kowtow" to Imperial officials]..." 6

Bureaucratic Organization of Foreign Affairs

Thus, the Imperial China of the early nineteenth century was not prepared either culturally or organizationally to enter into Western-style diplomatic relations. The government itself was of a feudal, imperial style which the West, with its emerging centralist, bureaucratic, and pluralist structures, had difficulty comprehending. At the head of the Chinese government was the Emperor, ruling by divine right without any written constitution or code of laws. Administering the edicts of the Emperor was a council or cabinet, the Grand Council (Chun-chi-chu), which had responsibility for affairs of state and covert military operations. 7

While the Grand Council was responsible for foreign affairs, for reasons previously noted it generally allowed such matters to be handled by officials of the coastal provinces. It was not until January of 1861 that liberal elements of the Grant Council, led by Prince Kung, petitioned the Emperor to establish a separate foreign office -- the Tsung-li Ko-kuo Shih-wu Ya-men, or Office in General Charge of Affairs 
Concerning All Foreign Nations, generally referred to as the Tsungli Yamen. Two months later, on March 11, 1861, the Tsungli Yamen was officially established, and the Grand Council relieved of all diplomatic duties. This probably represented a major triumph for the liberal, modernist faction in the Imperial Court. ${ }^{8}$ While independent of the Grand Council, the Tsungli Yamen was kept under tight Imperial control by keeping a Prince at all times in the directorship. ${ }^{9}$ The Tsungli Yamen operated until 1901 when, as a condition of the international protocol which followed the Boxer Rebellion, it was replaced by a more Westernized type of Foreign Office, the Wai-wu-pu. 10

Although the establishment of the Tsungli Yamen created for the first time a centralized authority for foreign affairs, other governmental institutions, such as provincial governments, still retained major roles in Chinese diplomacy. Ali provincial officials were appointed by the Emperor, and reported directly to him without any prior review from the Tsungli Yamen. Li Hung-chang, the Governor-General of Chihli Province and the Trade Superintendent in the North from 1870 to 1895 was especially influential dipiomatically, having almost the powers of a Secretary of state. Provincial opposition twice caused China to reject envoys from the United States. 11

Tsai characterizes the Chinese diplomatic structure as "complex, multi-faceted, inconsistent". ${ }^{12}$ It is obvious that the form of this structure, as well as the prejudices of the 
Chinese towards foreign emissaries, made a coherent and unified diplomatic strategy very difficult, and may in part account for some of the awkwardness and misunderstandings in Chinese-U.S. relations which will be detailed below. But if Imperial China was somewhat highhanded in its treatment of Western diplomatic initiatives, the imperialist and colonialist Western powers, including the United States, were even more overbearing in their relations with China. We will review below the attempts made by the Western powers to manipulate and colonize China in the nineteenth century.

THE COLONIZATION OF COASTAL CHINA BY THE WEST

Trade, Treaties, and war

The history of Chinese contact with the West is one of mutual misunderstanding and mistrust. The motivation of the Westerners in their contact with the Chinese was the promotion of trade. Such trade began in earnest in the late 1700's, and at first the chinese profitted from trade with the foreigners. Its traditional exports -- tea, silk, and porcelain -- were in great demand in the West; and markets for Western goods were limited in China both because of governmental control and by traditional preferences for native manufactures. 13

To reverse this trade imbalance, the English in the early 1800's began to import opium into China from India. ${ }^{14}$ Importation of opium was not only contrary to Chinese law, but also was responsible for disruption of the Chinese 
economy. Opium, because it was contraband, could not be exchanged for other goods, but must be bought with silver. While copper was used in China for everyday transactions, silver was the official currency, used to pay taxes and rent. The flow of silver out of the country due to the opium trade thus led to a devaluation of copper; Chen cites one source to the effect that the ratio of the value of silver to copper dropped from $1: 2$ to $2: 3$. Thus, it was the peasants of China -- whose income was received in copper but whose taxes were paid in silver -- who bore the brunt of the economic burden due to the opium trade. ${ }^{15}$ Also, the introduction of opium addiction to China undoubtedly led to some social disruption, again with the poor and the peasants being the most hurt.

The unfavorable balance of trade caused by opium importation and the increasing demands of the Western powers for even more trade opportunities were the major causes of the Opium War between China and Britain in 1839-1842.16 A second war between the Chinese and the British and French occurred in 1856-1860. The loss of these wars by the Chinese resulted in the opening of several Chinese "treaty ports" to Western trade, and a flooding of Chinese markets with Western goods -- particularly textiles. ${ }^{17}$ This resulted in further economic disruption and unemployment in China. The United States, seeing obvious trade advantages in the situation, sent a fleet of warships to China and eventually nogotiated trade privileges and the removal of its ships from Chinese jurisdiction through the Treaty of Wanghia in $1844 .^{18}$ 
America consistently maintained a favorable balance of trade with China. In 1885, exports to China amounted to $\$ 3,567,947$; while imports were almost twice this amount -$\$ 5,961,439.19$ As late as the early 1900's, the balance of U.S.-China trade was still distinctly unfavorable to China, with a deficit in the four years from 1903 to 1906 alone of over $\$ 38$ million. 20

These conflicts also resulted in diplomatic gains for the West. The Treaty of Tientsin in 1858 gave Britain and France the right to station Embassies in Peking, and specifically stated that Ambassadors of the Western powers would be treated as equals by Chinese cabinet-level officials in diplomatic transactions. 21

The Anglo-Chinese wars destroyed China's reputation as a military power, and it would not again be victorious over a foreign nation until the Second World war (and even then only with American assistance). It met disaster in wars with Japan in 1895, and in the Boxer Rebellion of 1900. In each of these military engagements China lost territory and sovereign rights, and was burdened with huge financial indemnities. $^{22}$ In the war with Japan these indemnities amounted to 200 million taels of silver, and the Boxer Rebellion resulted in an indemnity of 450 million taels. These financial burdens fell mainly upon the poor. 23 
Foreign Domination of Chinese Diplomacy

Foreigners, as part of this general pattern of domination, obtained many positions of influence in China's diplomatic structure. The Chinese Inspectorate of Customs (Tsung-shui-wu-ssu), a branch of the Tsungli Yamen, in 1853 included the consuls of Britain, France and the United States on its tariff committee. After the Treaty of Tientsin

(1858), a foreigner always held the position of Inspector General of Customs. 24 Chinese emigration was a profitable enterprise for Western shipping, and Westerners were involved in the determination of Chinese policies towards emigration. Americans helped China to conduct investigations and negotiations regarding the conditions of chinese immigrants in Cuba and Peru in the $1870^{\prime} \mathrm{s} .^{25}$ When China tried to control emigration to America (as a result of U.S. diplomatic pressure), it had to engage British cooperation to accomplish this. 26 The conduct of the negotiations leading to the Burlingame Treaty of 1868 is an especially important example of foreign involvement in the conduct of China's diplomatic affairs, because this treaty was directly concerned with chinese immigration to the United States, and was of predominant importance in the determination of American immigration policies over the next thirty-five years. The United states, through secretary of State Seward, had asked for a Chinese envoy to come to Washington to discuss immigration. The U.S. Consul, Anson Burlingame, volunteered for this position and was appointed by the Tsungli Yamen. Two Chinese officials 
were also assigned to this mission, and their credentials stated in Chinese that they were to be equal to Burlingame, although Burlingame, because he knew English, was to lead the negotiation process. Also, the legation was to have responsibility for negotiating ordinary matters only; important matters were to be referred to the Tsungli Yamen. However, in translating the credentials of the delegation the Secretary of the American Legation, S. Wells Williams, exaggerated Burlingame's powers to the effect that the two Chinese officials were said to be of second rank to Burlingame, and the mission was empowered to negotiate all matters. Despite these discrepancies in the conduct of the negotiations, the Burlingame Treaty was accepted by the Chinese government. 27

Western Attitudes Toward the Chinese

The Opium War also set a precedent of unequal treaties with the West; and while the Chinese had been forced to treat the Westerners as equals, the Westerners began to see the Chinese as distinctly inferior. The Chinese officials, who had been corrupted through the opium trade and then humiliated by defeat in war and the unequal trade treaties that followed, were viewed with contempt by Western diplomats. Lord Charles Beresford spoke of "the entire absence of good faith on the part of China in the observance of her treaty obligations". Sir Henry Norman stated that "Every Chinese official, with the possible exception of one in a thousand, 
is a liar, a thief, and a tyrant". And a well-traveled Californian and anti-Oriental agitator, Bayard Taylor, seemed to sum up the general attitude with his statement that "It is my deliberate opinion that the Chinese are, morally, the most debased people on the face of the earth."28 Articles of the time emphasized that the American motives in China were "humanitarian". Americans wished not only to engage in lucrative trade, but also "civilize" and "Christianize" the "natives". Brooks Adams, a turn of the century writer and historian, wrote:

Our geographical position, our wealth, and our energy preeminently fit us to enter upon the development of eastern Asia, and to reduce it to a part of our economic system. 29

And an article in the 1900 Harper's Bazaar held that: "... the gatling gun must blaze the way, shrapnel and shell must knock civilisation into the most bigoted and stubborn race in the world." 30

\section{China as a Colony of the west}

China was thus put into a position which, while not strictly colonial, was characterized by loss of jurisdiction in some of its own territory; domination by foreigners of its diplomatic affairs; a general colonialist, superior, and racist attitude on the part of foreign agents; and a situation of trade in which Western manufactured goods flooded domestic markets and Chinese raw materials and currency flowed out of the country with an unfavorable balance of trade. This situation vis-a-vis the Western powers was 
combined with an internal atmosphere of oppression, confusion, and political unrest as the Ch'ing Dynasty attempted to retain control over an increasingly dissatisfied and turbulent population.

The Chinese were thus repeatedly forced to back, down to foreign demands. In our discussion of Chinese-American immigration negotiations, we will see that the Chinese, though angered by the treatment of its nationals in the United States, could do nothing because it perceived itself to be in a situation of powerlessness and dominance by foreign powers. Thus, while China was not strictly a colony of the Western powers, its relationship with the West had all the aspects of a colonial relationship, particularly as regards the Western position in the coastal areas of China. This situation, and the attitudes towards the Chinese that were generated by it, could not help but to affect the status and treatment of Chinese immigrants in the United States. Tsai states that:

The characteristics of $\mathrm{Ch}^{\prime}$ ing diplomacy... and the different state systems of East and West partly explain the failure of the Ch'ing management of Overseas Chinese in the United States. Ch'ing political corruption and military weaknesses also help explain why the United States government dared time and again unilaterally to violate its treaties with China and continuously carry out anti-Chinese persecutions:31

THE CONDUCT OF CHINESE-AMERICAN RELATIONS, 1862-1905

Because of internal problems, foreign encroachments on its sovereignty, and the general process of dissolution 
occurring in the Ch'ing Dynasty, Tsai contends that "The United States was not a major problem to the Ch'ing government." 32 But he does feel that immigration was the most serious issue in American-Chinese relations in the nineteenth century •

Even before formal diplomatic relations existed, there was a significant amount of trade between the west coast of the United States and China. The Pacific Northwest, and Portland in particular, was one center of the early trade with China. In the 1840's and 50's, furs were the main export from the Pacific Northwest, ${ }^{33}$ and later there was considerable trade in wheat flour. ${ }^{34}$

The first American envoy to China was Major Samuel Shaw, who in 1786 was appointed U.S. Consul in Canton to oversee America's trading interests. ${ }^{35}$ canton was at that time the only port where foreign trade could be carried on.

The "Coolie Traffic"

One major source of shipping from China became the Chinese immigrants themselves. The British were the first to be involved in the so-called "coolie traffic", after the abolition of slavery in England in 1833. ${ }^{36}$ American shipping became involved in the brutal trade in coolies -- indentured laborers -- to Peru and Cuba shortly after this time, as we outlined in the last chapter.

The coolie traffic by American ships began to be of concern to American trade officials in China in the 1850's. 
These officials attempted to relieve the situation; but Chinese officials were indifferent to the situation, due to the official illegality prior to 1859 of emigration, and the low status of the emigrants. It must be remembered that while the rule against emigration, with its penalty of death, was by the nineteenth century a dead letter, it still acted to restrain Chinese officials from admitting to foreigners that emigration existed, or from cooperating in stopping the coolie traffic. The gentry and officials did attempt to warn the peasantry through the distribution of handbills cautioning them to beware of kidnappers. 37 But many of these ships sailed from areas outside of American influence, such as Hong Kong or Macao, or were chartered by non-American firms. Thus, these efforts by U.S. officials ended in failure. 38 But public reaction to this new form of "slave trade" gradually developed, and in $1862^{\circ}$ Congress prohibited American citizens in American vessels from transporting coolie labor. 39 Tsai concludes that the coolie trade "dominated Sino-American relations between 1850 and 1862."40

\section{Free Immigration}

The transport of free immigrants to the United states was another matter. As early as 1821, John Floyd, a U.S. Congressman from Virginia, made a proposal for the settlement of the Pacific Northwest in a Congressional report on "Occupation of the Columbia River": "It is believed that population could be easily acquired from China, by which the 
arts of peace would at once acquire strength and influence... 41 Nothing came of this novel proposal.

But transportation of Chinese immigrants to the United States through the credit-ticket system did begin in $1848^{42}$ and continued to grow until exclusion became law in the early 1880's. In one two month period in 1882, and from Hong Kong alone, seven British steamers brought 6086 Chinese to Portland. ${ }^{4}$ Barth says that this shipping had an important economic function, for "The traffic afforded employment for shipping at moments of great demand for freight." 44

The Burlingame Treaty

The first official United States legation to Peking arrived in the summer of 1862, and was led by Anson Burlingame. ${ }^{45}$ But American requests that China establish an Embassy in this country to represent its immigrants were ignored for many years, and it was not until 1876 that a Chinese Embassy was established, with a Consultate in San Francisco. 45

The first major treaty between China and the United States concerned with immigration was the Burlingame -or Tientsin -- Treaty of 1868. It gave the countries the right to exchange Ambassadors, disavowed U.S. intervention in Chinese affairs, and gave each country most favored nation privileges of travel and residence in the other country. ${ }^{4}$

But, while it was a treaty in many respects favorable to the Chinese, it was primarily the achievement of Americans. 
Anson Burlingame, the U.S. envoy, returned to the United States in 1865 to consult with Secretary of State Seward. The U.S. wanted to retain, but not increase, the present treaty port territories; increase American commercial and missionary activities in China; and induce more Chinese immigration, because the American Far West was at this time experiencing a labor shortage. Seward also wanted Burlingame to arrange for an envoy to be sent from China to discuss these matters. ${ }^{48}$ As we have seen, this delegation from China was headed by Burlingame himself. Coolidge says that "The Chinese embassy, with Mr. Burlingame at its head, was received in the United States with an almost continuous ovation." 49

The treaty was a highlight of Chinese-American relations, and almost unique in that it gave reciprocal rights to China. It granted rights to the Chinese in the United States that were not again to be gained by Asian-Americans until the 1960's.' The Burlingame Treaty; as approved by both governments, contained eight articles. It confirmed China's rights to its territories; China's rights to control its internal trade and navigation; China's right to appoint consuls to U.S. ports; freedom from religious persecution in either country (primarily aimed at protection of American missionaires); unrestricted immigration between countries; and reciprocal most favored nation rights of travel and residence. 50 
Several years later, with a labor surplus on the West Coast and increasing anti-Chinese agitation, many Americans thought less well of the Burlingame Treaty. But during this time, the executive branch of government maintained the provisions of the treaty against the pressure of both the Congress and the American people, until the passage of the scott Act in 1888 unilaterally repudiated and violated the Burlingame Treaty.

\section{Anti-Chinese Hostility}

Later diplomatic relations and treaties between China and the United States moved increasingly towards exclusion of Chinese from America. The completion of the transcontinental railroad in 1869, which released large numbers of Chinese into other areas of work, corresponded with a situation in which large numbers of white laborers were also unemployed, due in part to the depletion of the gold mines in California. The 1870's thus saw the first great wave of popular hostility against the Chinese.

But this period also saw the arrival of the first emissaries from China to the United States, in 1876. Chen Lanpin was the first Chinese Ambassador to America, and Frederick A. Bee became the Chinese Consul in San Francisco. Chen served until 1881. Because China was not used to sending emissaries to foreign nations, and thus lacked experienced diplomatic personnel, Chen Lan-pin held the posts of Ambassador to Spain (specifically the Spanish colony of Cuba) 
and Peru simultaneous to his American position. We have seen that conditions among the Chinese contract laborers in Cuba and Peru were very bad, and activities and investigations on behalf of Chinese residents of these countries naturally took up much of the time of these emissaries. Thus, insufficient personnel were available to fully take care of the affairs of Chinese residents in the United States. 51

Because of the popular hostility to the Chinese during this period, the new Chinese mission had many occasions to "protest official discrimination against the Chinese, which they saw as clear violations of the Burlingame Treaty. But, because of the powerlessness of China in the international community, these protests often went unheard.

Around this time, the first calls were heard for the abrogation of the Burlingame Treaty. But, as S. Wells Williams, the former U.S. Legation Secretary, pointed out in 1877:

It would furthermore be a strange proposal to make to the court of Peking, to abrogate a treaty almost forced on its acceptance, less than ten years ago, because the Emperor's subjects had acted on its suggestions more extensively than we expected. 52

In 1879 Congress passed the "Fifteen Passengers Bill", which limited to fifteen the number of Chinese that any one ship could bring to the United States. The Chinese emissaries immediately complained to secretary of State william Evarts that the bill was "offensive" and "insulting". S. Wells Williams, who was at this time teaching Chinese language and history at Yale, organized a petition to President 
Hayes opposing the bill, and signed by the entire Yale faculty. President Hayes then vetoed the bill to keep faith with the Burlingame Treaty, and the attempt to overrule the veto failed. 53 Tsai says that "It was, however, primarily a victory for Williams, Evarts and Hayes rather than for Chen and Yang [members of the Chinese delegation]." 54

In 1879 and 1880 the Chinese emissaries also filed many complaints over discriminatory actions by local officials on the West Coast. These complaints were often ignored by the local officials, and gained sympathy but little action from federal officials, who claimed that they had no jurisdiction. 55

\section{The Angell Treaty}

Political pressures due to the popular hostility against the Chinese convinced federal authorities that diplomatic action was necessary to limit Chinese immigration, and the Chinese were meekly acquiescent to these initiatives. In 1879 American Minister to China George F. Seward and Prince Kung, head of the Tsungli Yamen, agreed that "criminals, lewd women, diseased persons, and contract laborers" should be excluded from the United States. ${ }^{56}$ But President Hayes wanted something more than this, and in 1879 Seward was recalled and James B. Angell was made Minister Plenipotentiary to China with the mission of modifying the Burlingame Treaty so as to restrain, but not absolutely prohibit immigration. 57 
The conduct of these negotiations illustrate the ability of the Americans to virtually dictate treaty terms to China. The Americans first asked for the right to restrict or prohibit immigration, knowing that this position would be refused. The Chinese reacted strongly, pointing out that:

The Chinese have given a large amount of their labor to your people, and the benefits of that labor to your country have certainly not been few... Formerly, when there was a demand for these laborers, the only fear was that they would not go thither, and now because of the influence of violent men there exists a desire that they stay away. 58

They proposed that the four restrictions negotiated by Seward be implemented. But while the Chinese had merely made a statement of fact in their communication, the Americans considered it "offensive" and protested that:

You can scarcely mean to say that the Government of the United States is merely speaking the language of "violent men", or that the great nation in whose name it addresses you is "rabble". 59

The Chinese apologized. The Chinese objected to giving the United states total discretion in immigration, and the negotiations almost broke down; but Angell persisted, and on November 17,1880 the treaty was signed. 60

Article I of the Angell Treaty provided that

The Government of the United States may regulate, limit, or suspend such coming or residence, but may not absolutely prohibit it. The limitation or suspension shall be reasonable, and shall apply only to Chinese who may go to the United states as laborers.

And Article IV stated that

If the measures are found to work hardships upon the subjects of China the Chinese minister at Washington may bring the matter to the notice of 
the Secretary of State of the United States... to the end that mutual and unqualified benefit may result. 61

The treaty also stated that Chinese laborers already in the United States would have free rights of movement between China and the U.S., and would enjoy most favored nation privileges within the U.S. 62

Tsai states that "the treaty, as a whole, was favorable to the United States"; and that, although many controversies occurred in the interpretation of the treaty, "in practically every fight the policies of the United States government prevailed, no matter how eloquently and skillfully the Chinese officials argued their cases." 63

The Exclusion Act of 1882

The Angell Treaty was interpreted in America as allowing the United States to prohibit Chinese immigration for long, but defined, periods of time, and thus laid the groundwork for the Exclusion Acts of the 1880's. The first Exclusion Act was passed in 1882; it excluded all immigration of Chinese laborers for twenty years, and called for registration of all Chinese immigrants entering or leaving the United States. The new Chinese Minister to the U.S., Cheng Tso-ju, protested that this was too long a period, and suggested a five year suspension. President Arthur vetoed the bill, but a new bill, excluding the Chinese for ten years, was passed two months later and signed. The Chinese protested this act also. They felt that the registration provisions constituted 
an unfair hardship, because most Chinese laborers could not speak English. The United States finally agreed that registration certificates for those returning to visit China could be obtained from the Chinese Consulate, and that no fee would be charged. 64

The passage of the Exclusion Act was accompanied by anti-Chinese riots in the United States and anti-American riots in China. Riots in Denver in 1880 resulted in one Chinese being killed. Chinese Minister Chen Lan-pin demanded arrests and compensation, but this demand was refused personally by President Hayes on the grounds that the federal government could not interfere in local affairs. ${ }^{65}$ After the legislation was passed, this sort of hostility grew even more intense.

Many people, including Treasury Department officials, were convinced that the Chinese were cheating on the provisions of the act. It was said that entry certificates for teachers, traders, and students were being issued to laborers entering this country from Cuba. The 1882 legislation had given such laborers the right to pass through the U.S. on their way back to China. Due to this agitation, a new bill was passed in 1884 which prohibited Chinese from places other than China to enter the United States, and tightened regulations for issuing certificates. Chinese Minister Cheng protested that this law created undue hardship for those going to or returning from Cuba, but these protests were ignored. 66 Because the Angell Treaty specifically stated that Chinese 
laborers would have the right of transit through the U.S. on their way to other destinations, and would be protected from undue hardships, Tsai concludes that "The United States Congress utterly disregarded international comity and totally repudiated the treaties signed by China and the United states." 67

\section{Anti-Chinese Riots, 1885-1886}

The years 1885 and 1886 saw the most intense wave of anti-Chinese riots in the United States. Twenty-eight Chinese miners were killed in Rock Springs, Wyoming in 1885 . The new Chinese Minister, Chang Yin-hoon, protested the riot, demanded indemnities, and noted that none of the murderers had been punished. ${ }^{68}$ An indemnity bill was passed in 1887 granting $\$ 150,000$ to the survivors of the Rock Springs Massacre. It contained stipulations specifying that indemnity was granted because of generosity, not treaty obligations, and was not to be considered as setting a precedent. 69

The American Minister to China, Charles Denby, had been concerned that if an indemnity bill was not passed Americans in China would be endangered. Three anti-American missionary riots occurred in Chung-king, Szechuan Province; and in Kwei Ping and Tseng. Yuen, Kwangsi Province. No one was injured and there was little property damage, but Denby complained that Chinese officials had done little to stop the riots. The Tsungli Yamen, with magnificent irony, replied that this had also happened "rather too often" in Western countries. 
The Governor-General of Kwangsi, Chang Chi-tung, told American Consul Seymour that "American inhuman oppression of the Chinese was extreme and, compared with the two cases of Kwei Ping and Tseng Yuen, must be one hundred times as severe." 70 S. Wells Williams pointed out in 1885 that the Chinese had paid out $\$ 800,000$ in indemnities for losses to American citizens in its territory, some of which had been caused by British forces, but that America had been extremely lax in protecting the Chinese in its borders. 71

But the Rock Springs Massacre was only the first of a series of riots. The Army was called out to stop anti-Chinese riots in Seattle, and Chinese were expelled from several towns in Washington, including Tacoma and Puyallup. A riot in San Francisco burned down Chinatown and killed thirteen Chinese. The President of the Six Companies telegraphed the Tsungli Yamen asking them to demand that the U.S. President send troops to protect them, but nothing was done. ${ }^{72}$ The Snake River Massacre of 1887, at the Log Cabin Bar on the border of Oregon and Idaho, resulted in ten Chinese deaths. Four of the seven murderers were eventually arrested and tried in Baker, Oregon, but were found not guilty. ${ }^{73}$ Melendy estimates that 50 Chinese lives were lost in the 1885-86 riots, and $\$ 250$ million was lost in property damages. 74 
The Bayard-Chang Treaty

As a result of the 1885-86 riots, China reevaluated its position on emigration to the United States and decided on a policy of voluntary restriction of such emigration. Tsai states that the chinese reasoned that they could not retaliate for the treatment of Chinese in America either through war or through penalization of American residents in China, and therefore acquiesced to the voluntary restriction policy. 75

China expressed an interest in such a self-exclusion treaty in a letter to Denby from the Tsungli Yamen. U.S. Secretary of State Bayard and Ambassador Chang. started negotiations in 1886 for a treaty prohibiting immigration for twenty years; but they broke down in Chang's demand for indemnification for future anti-Chinese riots. ${ }^{76}$ In 1888, however, the Bayard-Chang Treaty was signed. It provided $\$ 276,000$ in indemnities for the Snake River, San Francisco and other riots that had occurred from 1885 to 1887, prohibited immigration of non-laborers, and allowed the return of laborers to the U.S. who had visited China and had families or property in the United States. 77

The treaty was ratified by Congress, but with many ammendments made by Republicans for political reasons. The Chinese government, however, was slow in ratifying the treaty. The treaty was humiliating to them, in that it was an admission that they had no power to aid their nationals in the United States. Chinese in Canton petitioned the 
Tsungli Yamen and held demonstrations against the treaty. Governor-General Chang of Kwangtung memorialized the throne against the treaty. The indications are, however, that the Tsungli Yamen, which had after all proposed the treaty originally, would have approved it. 78

The Scott Bill

But before the Tsungli Yamen could make a statement one way or the other, a rumor appeared in the London Times that the Chinese would reject the Bayard-Chang Treaty. Within a few days the U.S. Congress passed the strongly exclusionist Scott Bill. Immigrants who visited China were denied the right of returning to the United States, and the Burlingame Treaty was repudiated. The Tsungli Yamen was outraged by this bill, because the Bayard-Chang and Angell Treaties were never repudiated. They thus never recognized the scott Bill as valid. 79 But Tsai points out that

China was too weak and "too friendly toward the Americans" to take any retaliatory measures against 80 this one-sided violation of an international treaty.

And Coolidge is of the opinion that

not even the violation of the treaty of 1880 [the Angell Treaty] by the restriction law and the scott Act, could attract much attention from the Imperial Government while it was striving to hold the Empire together and save it from the rapacity of foreign powers. 81

The Chinese emissaries in the United States repeatedly attempted to undue the Scott Bill, but did not even receive a reply from the U.S. Secretary of State, who was a that time the Sinophobe James G. Blaine. 82 
Carey McWilliams says of the scott Bill:

This outrageous bill trapped some 20,000 Chinese who had temporarily left the United States, but who, at the time, had a perfect right of re-entry. In other words, it was tantamount to deporting 20,000 Chinese who had established lawful residence here. 83

\section{The Geary Act}

In 1892 the Geary. Act was passed, extending exclusion as formulated in the $1882 \mathrm{bill}$ for another ten years. It also denied Chinese bail in habeas corpos proceedings, and required registration of all Chinese in the United States. 84 Geary himself argued that the bill was necessary because the Chinese had violated prior treaties, but many senators saw the Geary Act as a way of absolving the U.S. of the bad faith and treaty violations inherent in the scott Bill. The newspapers almost unanimously condemned the Geary Act as racist and politically motivated. 85

The Chinese strongly protested the Geary Act as a violation of the Angell Treaty and the U.S. Constitution. They also complained that Chinese had no appeal from the discretion of the Collector of the Internal Revenue to issue or not issue a residence certificate. These objections were refused, and the chinese did not even receive a reply for six months. 86 The Chinese Six Companies of San Francisco, with the support of Chinese Minister Tsui Kuo-yin, organized resistance to the registration provisions of the Geary Act, and hired attorneys to fight the act in court. But in 1893 Minister Tsui gave up the fight against registration, and asked 
Chinese in the United States to comply with the Geary Act. China began to suspend emigration to America. 87

\section{The Gresham Treaty}

In 1892, Tsui resigned and was replaced by Yang Ju as Chinese Ambassador, who was given the assignment of negotiating a new immigration treaty. ${ }^{88}$ walter $Q$. Gresham was assigned as the U.S. negotiator for this new treaty, and was instructed by President Cleveland to "put an end to any semblance of treaty violation." 89 The Gresham Treaty was signed in 1894 and promptly ratified by both governments. Its provisions were similar to those of the unfortunate Bayard-Chang Treaty. It prohibited immigration of Chinese laborers for ten years, voided conditions of the scott Act preventing return from China of those immigrants with families in the U.S. and gave the right of transit to Cuban laborers. It also gave most favored nation status (except the right to become citizens) to Chinese in America; it accepted registration of Chinese but required registration of Americans in China; and it contained provisions to extend the treaty for an additional ten years if neither government formally terminated it. 90 The Gresham Treaty can be considered favorable to the Chinese, at least in comparison with the Bayard-Chang debacle, the Scott Bill, and the Geary Act. But it was not really a victory for Chinese diplomacy, but rather can be attributed to concern among American liberals for America's reputation in the international community. 
Implementation of the Exclusion Laws

Nevertheless, objections to foreign influence in China, especially among intellectuals, increased dramatically in the 1890's, culminating in the Boxer Rebellion of 1900. In 1892 the U.S. Ambassador to China, Charles Denby, reported that

The more intelligent among her people cite as grievances the importation of opium, the importation of manufactured goods, the introduction of steamers, the loss of Burma and Annam, extraterritoriality, the presence of missionaries and many other things. ${ }^{91}$

In the 1890's the provisions of the Geary Act were extended to the U.S. possessions in Hawaii and the Phillipines. In 1898 and 1900 acts were passed extending registration to Hawaii, although Hawaii had never experienced any "Chinese problem" or any anti-Oriental agitation. In 1899 the military governor, Gen. Elwell S. Otis, extended exclusion and registration to the Phillipines. A Congressional act in 1902, which was amended in 1904, extended Chinese exclusion to Hawaii and the Phillipines. 92

The 1890's and early 1900's also witnessed increased harrassment of Chinese in the United States. In 1902 a police raid in Boston to apprehend illegal aliens resulted in the arrest of 250 Chinese, but only five of these were found to be in this country illegally. One of these illegal aliens, Feng Hsia-wei, was deported to China, wrote a book on his experience, and then in 1905 committed suicide near the American Consulate in Shanghai. Several demonstrations were held in Feng's memory. In 1903 Ying Tan-kim, the 
Chinese military attache in Washington, was beaten by police without provocation. He also committed suicide out of humiliation. Thousands visited his grave. The police involved were not punished. In 1904 the United States invited representatives of all the Chinese provinces to conduct exhibits at the Louisiana Purchase Exhibition in New Orleans. Fifteen provinces sent delegations. These delegations were detained and jailed upon arrival. They therefore became convinced that Americans were a "race of pigs".93

Extension of Exclusion and Chinese Reaction

Following the Boxer Rebellion, the Chinese people became increasingly more militant against both the Ch'ing Dynasty and foreign involvement in Chinese affairs.

In 1904 the Gresham Treaty came up for extension by both governments. Chinese in the coastal provinces demonstrated against renewal of the treaty, and the chinese government eventually terminated the treaty. ${ }^{94}$ The U.S. Congress, however, passed legislation providing for continuation of exclusion even in the absence of Chinese government cooperation. 95

The Chinese people, particularly intellectuals, merchants, students, and labor leaders, were outraged by this action, and organized a boycott of American goods. The Shanghai Chamber of Commerce, led by T'seng Shao-ching, initiated the boycott. It developed into a nationwide movement, and continued into 1906. It was supported by many of the 
Overseas Chinese. 96 Tseng, in organizing the boycott, said that: "When our government proves itself unable to protest, then the people must rise up to do so." 97 A boycott pamphlet distributed in Fuchien in 1905 epxressed the attitude of the Chinese people well:

Who said the Chinese are patriotic? Who said the Chinese are nationalistic?... In order to exclude the Chinese, the United States adopted force, disregarded justice, ignored humanity, and violated international treaties. This was a great insult imposed upon all of we four hundred million Chinese. The reason why they dared to do this while we silently accepted the result was because they were united but we were not; they were strong but we were weak...98

Numerous anti-American demonstrations occurred. In July, 1905 in Amoy, the flag at the U.S. Consulate was torn down and smeared with muck. 99

But the Chinese government was weak, and feared both a popular uprising and the force of the United States. It at first rejected American demands that the boycott be suppressed, on thie grounds that this might lead to open revolt. However, on August 30, 1905 the Emperor Kwang Hsu issued a proclamation forbidding anti-American activities, including a boycott. Meanwhile, President Theodore Roosevelt attempted to remedy the more serious of the official abuses against the Chinese. 100

The boycott ended in failure. It never really affected U.S.-China trade. Samuel Gompers, in a virulently antiChinese pamphlet published by the A.F.L., reassured American business: 
There is not the slightest danger of any trade interruption. Our trade with China has constantly increased, in spite of our restriction policy and in spite of the so-called boycott engineered and fostered by the Japanese assisted by Asiatic-loving Americans. 101

Gompers was right. Trade statistics for the period show that in 1904 China had a trade deficit vis-a-vis the United States of $\$ 5,308,865$. In 1905, when the boycott was at the peak of its intensity, this deficit nevertheless rose to $\$ 25,789,029.102$ American shippers evidently gained dramatic profits from the lack of competition from Chinese exporters.

By this time exclusion of Chinese, which had been United States policy for over twenty years, was accepted, and taken for granted by the American public. It was the "Japanese problem" that held the public eye; the Chinese population was considered more or less harmless and uncontroversial. Following the failure of the boycott, the chinese also came to accept the fact of exclusion. Although many Chinese in the United States continued to struggle against their role as second-class citizens, their status in America ceased to be affected to such great extent by the U.S.-Chinese diplomatic relations.

Relations With the Nationalist Chinese Government

Thus, American diplomatic relations with the Kuomintang government that took power in China in 1911 had little effect on the situation of the Chinese in America. The status of the Chinese in America continued to be affected by the general prestige of China in the world, however. When sun 
Yat-sen visited San Francisco in 1909, many Chinese in America became enthusiastic about his movement. Dr. Sun was in favor of a strong, independent China free of foreign domination. Chinese in America could identify with this ideal. As one Chinese put it:

...people began to understand Dr. Sun Yat-sen because at the same time, they know they've been discriminated against, and pushed around so much...they wanted some way to get themselves a better way to survive.103

But Sun's revolution was not to end the confusion in China and its domination by foreigners. Sun abdicated shortly after taking power, and was replaced by Yuan Shihkai, who briefly attempted to rule as Emperor. Yuan was overthrown, and the new Communist regime in Russia for a time had much influence over the Chinese government. Russian envoy Michael Borodin reorganized the ruling Chinese party, the Kuomintang (KMT), along Soviet lines, and the Chinese Communist Party was founded. Warlords in northern China engaged in a series of revolts against the government, which were not put down until 1927 by Gen. Chiang Kai-shek. Chiang severed the alliance of the KMT with the Communists, and purged the urban workers' movement, making necessary the famous Long March. At this time the foreign treaty ports were still in existance, and an industrialization program was stagnating. Chiang allied himself with foreign and domestic business interests, and foreign influence was felt more than ever. 104 Japan made a series of humiliating demands upon China, and beginning with the Manchurian Crisis in 1931 began a 
program of military conquest. By 1940 the Japanese controlled most of China.

America continued to treat China with contempt. In 1924 a new exclusion law was passed, aimed primarily at the Japanese but also affecting the Chinese. Entrance of students to the United States was made more difficult and it became impossible for Chinese to bring their wives to America. 105 In 1927, U.S. warships shelled nationalist Chinese troops in Nanking, ostensibly in order to protect the Europeans in that city. 106

Repeal of Exclusion and Recent Relations with China

It was not until World War II, when China was seen as an important ally of the U.S. against both Japan and Communism, that the situation of American Chinese began to change. When Japan launched a full-scale invasion of China in 1937, Chinese in America helped to organize an effort to halt the sale of American scrap iron to Japan. ${ }^{107}$ This effort, while not particularly effective, did help to raise the American consciousness as to the situation of the Chinese. In 1943, with China seen as an American ally, a movement began for repeal of the exclusion laws, led by the Citizens Committee to Repeal Chinese Exclusion. ${ }^{108}$ This movement soon gained support from many organizations and many politicians, including President Roosevelt, who said of the repeal bill: "I regard this legislation as important in the cause of winning the war... By the repeal of the Chinese exclusion laws we can 
correct a historic mistake."109. But this bill, which was quickly passed, set a quota for Chinese immigration of only 105 a year. It and the later McCarran-Walter Immigration Act of 1952 simply changed outright exclusion to severe restriction. 110

The establishment of the People's Republic of China in 1948 and the intense anti-Communist paranoia in America during the 1950's again affected the status of the Chinese in the United States. Although most American Chinese, and almost all Chinese organizations were sympathetic to the Kuomintang regime on Taiwan, American authorities nevertheless looked at Chinese in the United States with suspicion. J. Edgar Hoover warned that Chinese in the U.S. "could be susceptible to recruitment through ethnic ties or hostage situations because of relatives in Communist China."111 The McCarran-Walters Act; which not only set very low immigration quotas for Asians, but also provided for detention of suspect aliens in concentration camps in time of emergency, was a product in part of this anti-Communist paranoia. 112

The civil rights atmosphere of the 1960's finally saw some opening up in the situation for Chinese in America. At this time, however, many Chinese had been here for generations and had become more or less assimilated into American culture. Therefore, we cannot see the improvements of the 60 's as entirely a product of United States relations with China or other Third World countries. 
But the increasing power of the People's Republic of China in the world did create more respect for Chinese people. One Chinese interviewed by the Nees says that Mao made China respectable, and that "Before, we used to lower our eyes before the white man. Now we can look straight at them without being afraid."113 The Nixon repproachment with the PRC was greeted with pleasure by most Chinese in America. The Nees said of the San Francisco Chinatown in 1971: "the acute sense of racial tension seemed to be subsiding in the wake of the start of improved relations between the United States and China." 114 The Oregonian interviewed several Portland Chinese about Nixon's trip, all of whom reacted favorably. 115

Comparison of the Chinese and Japanese Experiences

The case of Japanese immigration is an interesting contrast to the situation of the Chinese in America. Immigrants from both countries were racially oriental. Immigrants from China and Japan were both mainly from the lower peasant or farmer classes, motivated to come to America by conditions of rapid economic and political change at home. But Japan in the early 1900's was a strong nation militarily, with an effective central government, and a policy of protecting its overseas nationals from injustice. The status of the Japanese immigrants was thus much higher than that of the Chinese. While the Chinese worked as manual laborers, domestics, or laundrymen, the Japanese, even the recent arrivals, 
were often able to enter traditionally "white" areas of employment. Many owned their own farms or businesses. There were few Japanese ghettoes to compare with the Chinatowns that had sprung up all over the West Coast. Although there was considerable racial hostility against the Japanese, the government and courts were much more active in preserving Japanese rights than they had been in relation to the Chinese.

In 1906, the San Francisco Board of Education ordered the exclusion of Japanese and Korean children from the public schools. Japan protested that this order was in violation of a treaty with the U.S. While the chinese had failed to gain the attention of the U.S: government in similar situations, the Japanese, who had defeated China in the 1894 war and Russia in 1905, got immediate attention from President Roosevelt. 116 Secretary of State Elihu Root drafted a memo stating that "Japan is ready for war... The loss of the Phillipines, Hawaii, and probably the Pacific Coast would occur before we were ready for a real fight." ${ }^{11}$. The school board rescinded its order six months after it had been issued; but the incident led to the formulation of the "Gentlemen's Agreement" between the United States and Japan, which in 1907 allowed for voluntary prohibition by Japan of emigration of laborers. 118

In 1913 California prohibited Japanese from owning land. Again, an international incident resulted as the Japanese government forcefully protested these restrictions. Melendy 
observes, however, that "the land law applied equally to the Chinese, but no one was concerned about their rights since China did not have a strong navy or a good war record."119 This is not to say that the Japanese in the United States were not oppressed. They too were barred from citizenship; and as we have just mentioned they were barred from owning land in California (and later in Oregon and Washington). They suffered racial hostility and discrimination, as the Chinese did. But all these things were mitigated by the strong international standing of their home country, which made it possible for Japan to vigorously defend the rights of its nationals overseas.

It can be seen that much of the oppression and passivity of the Chinese in the United States is a result of the general weakness of the Chinese government, and its domination by foreign powers. It now remains to determine the characteristics that would constitute a "colonized minority" in the United States and, using the data presented above, determine whether the Chinese in America have such characteristics.

THE CHINESE IN AMERICA AS A COLONIZED MINORITY

The problem of this section is: Given the data above, how can we best describe the position of the Chinese people in American life, and their relationship to the majority white society? 
Social activists have promoted the idea that people of color in the United States constitute a Third World group, with common problems and common status in the white society due to this fact. It is said that their position is similar to that of colonial subjects -- they are restricted to manual labor or domestic types of employment; their housing is restricted to segregated ghettoes, and their life is dominated by a system of white control. The Asian American Task Force of the Council on Social Work Education shares this viewpoint:

In particular, Asians share the shift in perspective vis-a-vis the relationship of people of color to American society. Third World people today view themselves as occupying the status of colonial subjects -- a status maintained for power and profit by vested political and economic interests. 120

We wish to examine whether this statement is an accurate one, and if so, what mechanics operate in such a system of racism and internal colonialism. We are limited in these efforts by a lack of material in the literature on the mechanics of racism, or at least on such mechanics as relevant to Asian Americans.

Theories on the Mechanics of Racism

Harry Kitano provides one such system based on Milton Gordon's model of acculturation and assimilation. He basically defines three variables with which to measure a group's degree of assimilation and position in the social structure: ethnicity, social class, and generation (i.e. first generation American, second generation, etc.). ${ }^{121}$ He analyzes 
these variables as they relate to five ethnic groups -black, Jew, Catholic, Puerto Rican, and Japanese -- and concludes that "According to the schema, only the Puerto Rican has not been culturally assimilated (acculturation), that is, has not taken on the values, skills, and behaviors of the host, middle-class American society. " 122

From this statement, we begin to see some of the inadequacies (for our purposes) of Kitano's system. First, we do not believe that taking on the characteristics of the white middle-class is necessarily a beneficial development for an ethnic group. We will discuss this idea further in later chapters; but briefly, we believe that many ethnic groups, and especially the Chinese, wish to retain at least some of the "values, skills, and behaviors" of their ancestral culture. Second, the contention that the black, or even the Jew or Japanese, has been fully assimilated seems on the surface to be highly questionable. Third, this model seems to imply that assimilation is merely a matter of nonwhites taking on white values. In actuality, of course, there are institutional barriers that restrict opportunity and keep the non-white in a subordinate position. We feel that such social; political, and economic factors are crucial to the analysis of the historical position of the chinese in America. Therefore Kitano's system is of little use to our study.

Another theory of the mechanics of racism which we are acquainted is that developed by Kitano and Roger Daniels in 
their book, American Racism. 123 This "two-category system" is much more dependent on the variable of race, and its key idea is stated: "The major projected outcome of the twocategory system is that every white man, no matter how 'low', is above every non-white, no matter how 'high'."124 It defines four stages of racism: 1.) prejudice, avoidance, and stereotyping; 2.) discrimination, legal or structural; 3.) segregation, institution of well-defined racial boundaries; and 4.) exclusion, expulsion, or genocide. ${ }^{125}$ while we can see that the Chinese in the nineteenth century experienced prejudice, legal and structural discrimination, segregation, and exclusion, this schema still strikes us as merely descriptive, rather than being an explanation of the mechanics involved in racism.

An interesting idea in the Daniels and Kitano study is that the degree of prejudice is related to the degree of darkness of the skin, and that in a given area, those with the darkest skin will be the most discriminated against. Thus, in areas with few blacks, Asians and American Indians receive the most racial discrimination and hostility. ${ }^{126}$ We observe that this has been the situation on the West Coast.

Pierre Van den Berghe provides a more structural analysis of the nature of racism. He contends that racism is not only a matter of racial differences, but involves differences in status and culture. In other words, for racism to exist, a situation must exișt in which a clearly dominant and a clearly subordinate group are defined; and these groups must 
be easily identifiable through racial characteristics. Such situations are often a function of the way in. which a given ethnic group entered America, and Van de Berghe says they are most apt to occur in migrations involving military conquest, frontier expansion, and involuntary migration. ${ }^{127} \mathrm{He}$ also says that in the nineteenth century this dominantsubordinate relationship often resulted from colonial expansion, and defines three factors which allowed for the development of racism in this situation:

1. Racism was congruent with prevailing forms of capitalist exploitation... 2. Racism was congruent with the new Darwinian current of thought in the biological sciences... 3. Racism provided a rationalisation for slavery and colonialism in a time of a prevailing egalitarian ideology. 128

These ideas seem applicable to the colonial situation in China in the nineteenth century, and help to explain why anti-Chinese racism came into existence. It remains to determine how racism operated in the context of America's political and economic institutions during this period.

Blauner's Thesis on "Colonized Minorities"

We believe that Robert Blauner provides a comprehensive set of criteria for defining the actual mechanisms of structural racism in America. ${ }^{129}$ we will use this set of criteria to try to determine whether the Chinese in the United States can be characterized as a colonized, Third World people. The basis for our contentions here is the fact that the Chinese nation, as we have shown, was under the domination of foreign powers. Our contention is that this domination was a prime 
determinant of the situation of the Chinese laborers in the United States. Blauner recognizes this factor when he states :

If one looks at the place of the various racial minorities in America's stratified economic and social order, one finds a rough correlation between relative internal status and the international position of the original fatherland.130

Other writers have also commented on this fact. Daniels and Kitano stated: "The permeability of social boundaries for immigrant groups has often been determined by the relationships between their homelands and America."131 And Franklin odo et. al. write:

All ethnic groups in the United States work with the assumption, explicit at some times, implicit at others, that the nature of the relations between the U.S. and the nations from which their ancestors came have much to do with their own fates.132

But Blauner defines other criteria as well. Blauner's thesis is that oppression of Third World peoples is essentially a product of racism. He defines racism in a straightforward sociological:manner, as the "oppression of one group by another" based on race consciousness. ${ }^{133}$ To Blauner, as with Van den Berghe, racial oppression is based on interrelated economic and social factors. Thus, the racially oppressed are kept in low-level labor employment positions, and whites therefore are given a higher social status as a result. 134 In this context, it can be observed that a key objection of racists to having Chinese in traditionally white areas of employment was that this would degrade white labor. 
The concept of a colonized minority is obviously founded on an analogy of the position of natives in European colonies to the situation of people of color in the United States. In an actual colony, the whites are the foreigners and in the minority, and in the United states the situation is obviously the opposite as regards the position of people of color. But the point is that the conditions of domination and oppression remain the same. There is also a relationship between actual colonialism and the situation of Third World peoples in the U.S.:

The economic, social, and political subordination of third world groups in America is a microcosm of the position of all peoples of color in the world order of stratification. 135

odo et. al. also write:

It would be difficult to argue a point by point analogy between neo-colonialism (economic control) abroad and the position of Asian Americans but certain elements are worth noting. In both cases (neo-colonies and Asian Americans) the two distinctive patterns are their relative powerlessness and the systematic exploitative relationships that exist between us and our government. 136

And Stanford Lyman contends that: "In effect, the Chinese community in America is more like a colonial dependency than an immigrant settlement in an open society."137

The Criterion of Involuntary Immigration

Colonized immigrants, Blauner says, do not enter the country in the same way and do not have the same status after their entrance as in the traditional patterns of European immigration to the United States. 
Immigrant groups enter a new territory or society voluntarily, though they may be pushed out of their old country by dire economic or political oppression. Colonized groups become part of a new society through force or violence; they are conquered, enslaved, or pressured into movement. 138

While the Chinese were indeed "shanghaied" by Westerners and brought, in conditions of debt servitude, to many countries, we have little evidence that outright "force or violence" operated in the movement of the Chinese to the United States. But we have seen that China was in a sense "conquered" by the Western powers. Western oppression was certainly a significant contributing factor for Chinese migration to America, and we have seen that such migration was heatedly promoted by western shipping and labor contractors in China, for whom Chinese emigration was an immensely profitable business.

\section{Unfree Labor Conditions}

As important as unfree immigration in Blauner's scheme is unfree labor conditions. 139 In the next chapter we will see that Chinese laborers on the railroads, in the mines, and in many employment situations were strictiy controlled by bosses or labor contractors -- both Chinese and American. They were also restricted to types of employment where they would not compete with whites. It must also be noted that, because of the condition under which they arrived in America, Chinese laborers did not bring their wives or families with them. They were thus laborers only -- not permanent residents or raisers of families. 
Restriction on Freedom of Immigration

Restriction on freedom of immigration is another of Blauner's characteristics of the colonized minority which definitely applies to the Chinese. 140 Exclusion resulted in a situation in which many Chinese were in this country illegally. Also, until 1943 Chinese immigrants were legally prohibited from becoming citizens. Such restrictions obviously served to dominate and oppress the Chinese residents in the United states. Blauner points out that exclusion acted to both define the status of the chinese and to limit their numbers and potential power. ${ }^{141}$

Restricted Mobility

A fourth criterion Blauner suggests for characterizing colonized minorities -- along with forced entry, unfree labor, and restrictions on immigration -- is restricted mobility within the United States. ${ }^{142}$ we do not feel that this restriction applies unconditionally to the chinese. When the Chinese miners were persecuted in California, many of them moved on with no difficulty to Oregon, Washington, and Canada. But there are also examples of Chinese laborers being moved from place to place at the whim of the labor contractors. As we shall see in Chapter. $V$, they were used as strike breakers in several New England towns, and were brought in arbitrarily by the plant managers from California. Most importantly, Chinese were restricted in housing opportunities. Everywhere Chinese lived in the United States, 
there was a Chinatown, or Chinese ghetto. The Chinatown in part represented a voluntary segregation on the part of Chinese; a method of gaining mutual support and protection. But it was also an indication of the racial boundaries imposed on the Chinese by white society. Pei-ngor Chen observes that "Although Chinatowns emerged as evidence of voluntary segregation, they were also the result of external pressure and racial discrimination." 143 while there undoubtedly were some positive aspects to this system, it served to restrict Chinese mobility, physically and socially, in American society.

Restriction to Preindustrial Labor

All of these characteristics are related to what is perhaps the key criterion espoused by Blauner: That colonized peoples are used as an elastic, cheap labor supply; and they are restricted to preindustrial segments of the economy. Blauner states that: "...third world workers fit Marx's conception of an industrial reserve army, which meets the system's need for an elastic labor pool."144 and again:

...the stereotype has long existed that Asians and Indians were not fit for factory work. For the most part then, third world groups have been relegated to labor in preindustrial sectors of the nonagricultural economy. Chinese and Mexicans, for example, were used extensively in mining and building railroads, industries that were essential to the early development of a national capitalist economy, but which were primarily prerequisites of industrial development rather than industries with any dynamic future.145

Other writers concur with this observation. Saxton says of the situation in California in the 1870's: 
Viewing the state as a whole, then, Chinese were found in occupations which reauired little or no skill, in occupations stigmatized as menial, and in manufacturing. In a general way, the divisions between Chinese and non-Chinese corresponded to lines of skill or prestige. 146

Thus, when these colonized people worked in areas of unskilled or semi-skilled labor they were accepted, even welcomed by the whites, but when they attempted to move out of these restricted areas of employment, the white population inevitably reacted with strong hostility. Blauner provides the example of the Japanese, who...

...were viewed as fit only for subservient field employment. When they began to buy land, set up businesses, and enter occupations "reserved" for whites, the outcry led to immigration and exclusion acts.147

The same circumstances also applied to the Chinese. The result was that Chinese labor was said to be unfit for, and "degrading", to whites; and white labor too good for Chinese. Charles A. Crocker, the general manager of the Central Pacific Railroad at the time of the construction of the transcontinental railroad, made the following statements in testimony before a Congressional special committee in 1877:

Question: State what, in your judgment, is the effect upon white labor, whether they (the chinese) have the effect to deprive white men of employment, or have they had that effect at any time?

Answer: I think they afford white men labor. I think that their presence here affords the white man a more elevated class of labor. As I said before, if you should drive those 75,000 Chinamen off you would take 75,000 white men from an elevated class of work and put them down to doing a low class of labor that the Chinamen are now doing, and instead of elevating you would degrade white labor to that extent. 148 [emphasis added] 
And William Hollister, a California farmer, said of the Chinese at the same hearings:

He descends to the lowest employments, and, when properly treated, thinks of no degradation in the lowest labors. In short, he is willing to be the mudsill, and take the very bottom round of the social ladder... They perform the menial labors of our household, and in general do so much of our commonest toil that they pave the way for the higher labors of the better races. 149

An additional example of this point is provided by a table in Coolidge showing that demand for unskilled and semi-skilled laborers in California in 1868-69 was excessive, but there was at the same time a surplus of skilled laborers. ${ }^{150}$ When Chinese around this time began to enter several industries requiring skilled labor, beginning with the cigarmaking industry, agitation against them immediately began. 151 We can also observe that the completion of the railroads and depletion of the mines, which drove many Chinese into traditionally white areas of work, resulted in a wave of antiChinese hostility. The Chinese remained restricted to employment as domestics, field laborers, laundrymen, restaurant workers, etc. well into the middle of the twentieth century:

\section{Cultural Imperialism}

A final characteristic of colonized minorities mentioned by Blauner is cultural imperialism -- the suppression of the colonized immigrant's traditional style of living and mode of social relationships. ${ }^{152}$ We have already mentioned the fact that the Chinese in America in the nineteenth century were separated from their wives and children -- virtually 
without any family life. We saw in the last chapter that this fact amounted to severe social deprivation for the chinese in America, and was responsible for considerable social aberrations in the Chinese community. Coolidge quotes the 1904 statement of a Chinese official, Chang Kiu Sing, concerning the legal prohibitions preventing Chinese from having families in America: "They call it exclusion; but it is not exclusion, it is extermination." 153 Blauner also points out that in California "various aspects of Chinese culture, dress, pigtails, and traditional forms of recreation were outlawed." 154

Chia-lin Chen provides a translation of a 1921 article by a Chinese student in Portland who complains of regulation of Chinese language schools by the state government in California: "I am afraid there will be no more Chinese language schools in the United States; and our rights to learning Chinese will be ruled out eventually."155 And the Nees tell of an interview with Frank Chin, a contemporary Chinese writer, in which he complains of the difficulty he had in publishing literature based on a Chinese-American perspective. He says: "Writing is white, the standards of art and culture are white, and this tyranny of culture by the whites has been an oppressive force on nonwhite arts."156

Thus, many factors -- coerced entry into the United States, unfree labor, immigration restrictions, restricted mobility, restriction to preindustrial areas of labor, cultural imperialism, and the colonization of the home country-- 
all point to the conclusion that the Chinese in America can be considered a colonized minority. The Chinese-American community meets almost all of the criteria proposed by Blauner.

\section{SUMMARY}

In this chapter, we have established that China in the nineteenth century was dominated by the influence of Westerners, who were motivated by trade considerations: Also, the Ch'ing Dynasty was decaying, falling apart during this time; central government was weak. Due to these and other factors, many Chinese sought a better life in the United States, but the Chinese government was powerless to protest on their behalf against the racist discrimination they found there. The Chinese officials were manipulated by the United States into several unequal treaties regarding Chinese immigration, and the U.S. eventually succeeded in altogether excluding Chinese immigration. This weak position of the Chinese government in the international community resulted in a situation of colonialized domination for the Chinese people in America. We used the criteria of Robert Blauner to detail the mechanisms through which this colonialization of the. Chinese Americans operated. We found that the situation of the Chinese in the United States met most of Blauner's criteria. Thus, we conclude that the Chinese in the United States, along with other people of color, are basically a colonized minority, discriminated against and oppressed by 
white society as a result of the weakness and lack of development of their native country; although it should be noticed that both the position of China in the international community and the position of the Chinese in American society are at present becoming more secure. 
${ }^{1}$ Robert Blauner, Racial Oppression in America (N.Y.: Harper and Row, Publishers, 1972).

${ }^{2}$ Shin-Shan Henry Tsai, "Reaction to Exclusion: Ch'ing Attitudes Toward Overseas Chinese in the United States, 18481906", (Ph.D. dissertation in History, University of Oregon, $1970)$.

3 Mary Roberts Coolidge, Chinese Immigration, (N.Y.:Henry Hold and Co., 1909; reprinted., N.Y.:Arno Press and The New. York Times, 1969), p. 11 .

${ }^{4}$ Tsai, p. 8.

${ }^{5}$ Quotation cited in Gunther Barth, Bitter Strength: A History of the Chinese in the United States, 1850-1870, (Cambridge, Mass.: Harvard University Press, 1964), p. 141.

${ }^{6}$ Viola Noon Currier, "The Chinese Web in Oregon History", (Masters thesis, University of Oregon, 1928), pp. 1213.

$$
\begin{aligned}
& 7_{\text {Tsai, pp. } 2-5} \text { passim. } \\
& 8_{\text {ibid., p. } 10} \\
& 9_{\text {ibid., pp. } 14-15} \\
& 10_{\text {ibid. , p. } 19} \\
& 11_{\text {ibid., pp. } 21-29} \\
& 12_{\text {ibid., p. } 333 .}
\end{aligned}
$$

${ }^{13}$ Chia-lin Chen, "A Gold Dream in the Blue Mountains: A Study of the Chinese Immigrants in the John Day Area, Oregon, 1870-1910", (Masters thesis in History, Portland State University, 1972), p. 20 .

14 ibid., p. 20 ; and Barth, p. 26.

${ }^{15}$ Chen, pp. 20-21. 
16ibid., p. 18; and H. Brett Melendy, The Oriental Americans, (N.Y.:Twayne Publishers, Inc., 1972), p. 10.

17 Melendy, pp. 10-11; and Chen, pp. 21-22.

${ }^{18}$ Frederick A. Bee, The Other Side of the Chinese Question -- Testimony of California's Leading Citizens, (San Francisco:Woodward and Co., Printers, 1888; reprint ed., San Francisco: R and E Research Associates, 1970), p. 10; Tsai, pp. 52-58; and Melendy, pp. 10-1l.

${ }^{19}$ Bee, p. 68 .

${ }^{20}$ Coolidge, table on "Exports from the United States", p. 482 .

$21_{\text {Tsai, p. } 9 .}$

${ }^{22}$ Chen, pp. 18-19.

23 ibid., p. $24 \mathrm{n}$; ; and Rose Hum Lee, The Chinese in the United States of America, (Hong Kong:Hong Kong University Press, 1960), p. 11. Lee's book' is frequently cited as a definitive study of the Chinese in America. While it is scholarly and contains impressive statistics, it also contains many errors of fact. For example, Lee claims that registration of Chinese in America was not required until 1939; it was actually instituted in 1888 .

$$
\begin{aligned}
& 24 \text { Tsai, pp. 21-22. } \\
& 25_{\text {ibid., pp. } 127-129 .} \\
& 26_{\text {ibid., p. } 244 .} \\
& 27_{\text {ibid., pp. } 119-123 .}
\end{aligned}
$$

${ }^{28}$ All quotations cited in Samuel Gompers and Herman Gutstadt, Meat vs. Rice: American Manhood Against Asiatic Coolieism: Which Shall Survive?, (San Francisco:American Federation of Labor and the Asiatic Exclusion League, 1908), pp. $29-30$.

29 Robert McClellan, The Heathen Chinese: A Study of American Attitudes Toward China, 1890-1905, (Columbus, Ohio: ohio State University Press, 1971), p. 163. 
${ }^{30}$ ibid., pp. $220-221$.

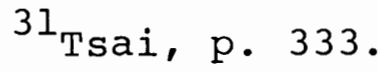

32 ibid., p. 19.

33 Fred Lockley, History of the Columbia River Valley, (Chicago:The S.J. Clarke Publishing Co., 1928), Vol. I, p. 54.4 .

34 ibiä., pp. 546-547.

${ }^{35}$ Lee, p. 7 .

${ }^{36}$ Melendy, p. 13.

37 Tsai, pp. 67-71.

38 ibid., pp. 63-64.

${ }^{39}$ Melendy, p. 13.

$40_{\text {Tsai, p. } 42 .}$

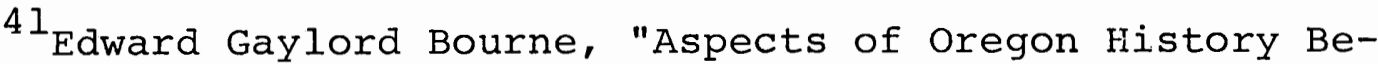
fore 1840", Oregon Historical Quarterly, VI (September 1905), p. 255 .

42 Melendy, p. 13.

${ }^{43}$ Lockley, p. 545 .

44 Barth, p. 59. See also Elmer C. Sandmeyer, The AntiChinese Movement in California, (Urbana, Ill.:University of Illinois Press, 1973), p. 15.

$45_{\text {Tsai, p. }} 31$.

46 ibid., p. 126.

47 Melendy, pp. 10-11.

48 Tsai, pp. 116-119; and Coolidge, pp. 145-167 passim. 
$49_{\text {Tsai, p. } 147 .}$

$50_{\text {ibid., p. } 124 .}$

${ }^{51}$ ibid., pp. 33-39.

52 Six Chinese Companies, Memorial: An Address to the Senate and House of Representatives of the United States, (San Francisco:Six Chinese Companies, 1877; reprint ed., San Francisco:R and E Research Associates, 1970), p. 51.

53 Tsai, pp. 155-159.

54 ibid., p. 159 .

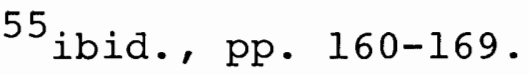

56 ibia., p. 171.

57 ibid., pp. 171-174.

58 ibid., p. 178 .

${ }^{59}$ ibid., p. 179 .

$60_{\text {ibid., pp. } 177-183 .}$

${ }^{61}$ Bee, pp. 13-14.

62 Tsai, pp. 185-186; and Coolidge, pp. 145-167 passim.

$63_{\text {Tsai, p. } 186 .}$

64 ibid., p. 187 and pp. 201-210.

$65_{\text {ibid., p. } 188 .}$

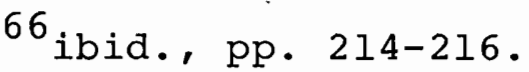

67 ibid., p. 217.

${ }^{68}$ Melendy, p. 40. 
$69_{\text {Tsai, p. } 228 .}$

$70_{\text {ibid., pp. 230-231. }}$

${ }^{71}$ Bee, pp. 11-12.

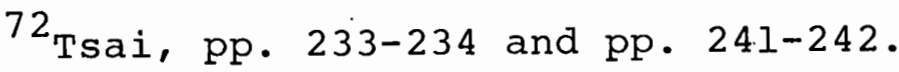

73 ibid., pp. $249-251$.

74 Melendy, p. 237.

75 Tsai, pp. 242-243.

${ }^{76}$ ibid., pp. 245-249.

77 ibia., pp. 245-257.

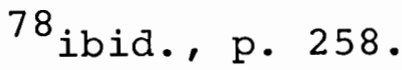

79 ibid., pp. 261-268.

${ }^{80}$ ibid., p. 268.

${ }^{81}$ Coolidge, p. 462 .

${ }^{82}$ Tsai, pp. $271-278$.

${ }^{83}$ Carey McWilliams, Brothers Under the Skin; (Boston: Little, Brown and Co., 1943), p. 89.

$84_{\text {Tsai, p. } 279 .}$

${ }^{85}$ Coolidge, p. 209 and pp. 217-218.

${ }^{86}$ ibid., p. 222; and Tsai, p. 280.

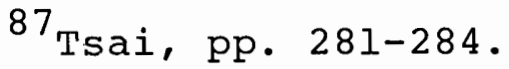

${ }^{88}$ ibid., p. 287.

${ }^{89}$ ibid., p. 288. 
$90_{\text {ibia., pp. } 288-289 .}$

${ }^{91}$ Coolidge, p. 466 .

92 Tsai, pp. 292-293.

93 ibid., pp. 297-300.

${ }^{94}$ Stephen W. Nickerson, "Our Chinese Treaties; and Legislation; and their Enforcement", North American Review, CLXXXI, (September 1905), pp. 370-371.

95 Melendy, p. 60 .

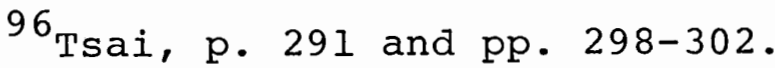

97 ibid., p. 301.

98 ibid., p. 308 .

99 ibid., p. 320 .

100 ibid., pp. 311-324; and Coolidge, pp. 470-474.

$101_{\text {Gompers, p. } 20 .}$

${ }^{102}$ Coolidge, table on "Exports from the United States, p. 482 .

103 Victor G. and Brett De Bary Nee, Longtime Californ': A Documentary Study of an American Chinatown, (N.Y.:Pantheon Books, 1973), p. 79.

104 ibid., pp. 202-204.

${ }^{105}$ Lee, p. 14 .

106 "U.S. Guns Shell Cantonese Mobs", Oregonian, March 25, 1927 , p. I, C. I.

107 Wei Min She Labor Committee, Chinese Working People in America (San Francisco:United Front Press, 1974), p. 40. 
${ }^{108}$ Melendy, p. 64 .

109 ibid., p. 65.

$110_{\text {ibia., p. } 66 .}$

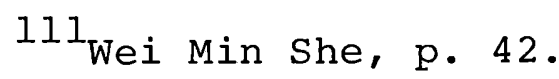

112 ibid., p. 46.

113 Nee, p. 83 .

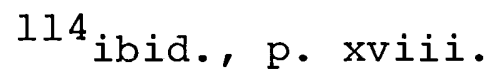

115 "Chinese Community Happy about 'Thaw'", Oregonian, April 17, 1971, p. 17 c. 2-3; and "Portland Chinese Favor Trip of Nixon", Oregonian, August 20, 1971, p. 35 c 1-3.

${ }^{116}$ Melendy, pp. 106-108.

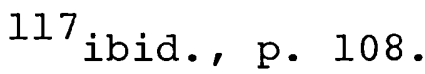

118 ibid., pp. 111-112.

119 ibid., p. 122 .

120 Asian American Task Force, Council on Social Work Education, Asian American Task Force Report: Problems and Issues in Social Work Education, (N.Y.:CSWE, 1973), p. 2 .

$121_{\text {Harry H.L. Kitano, Japanese-Americans: The Evolution }}$ of a subculture (Englewood Cliffs, N.J.:Prentice-Hall, Inc., 1969), pp. 4-5.

122 ibid., p. 6 .

123 Roger Daniels and Harry H.L. Kitano, American Racism: Exploration of the Nature of Prejudice, (Englewood Cliffs, N.J.:Prentice-Hall, Inc., 1970).

124 ibid., p. 6.

125 ibid., p. 12 : 
126 ibid., p. 90.

${ }^{127}$ Pierre Van den Berghe, "Racism in Western Civilisation", in Cracks in the Melting Pot: Racism and Discrimination in American History, Melvin Steinfield, editor (Beverly Hills, Ca.:Glencoe Press, 1970), (pp. 16-23), pp. 18-19.

128 ibid., p. 21 .

129 Blauner, op. cit.

130 ibid., p. 72 .

${ }^{131}$ Daniels and Kitano, p. 92.

132 Franklin Odo with Mary Uyematsu, Ken Hanada, Peggy Li, and Marie Ching, "The U.S. in Asia and Asians in America", in Roots: An Asian American Reader, Amy Tachiki, Eddie Wong, Franklin Odo, and Buck Wong, editors. (Los Angeles:UCLA Asian American Studies Center, 1971), p. 223.

133

Blauner, p. 21 .

134 ibid., p. 27.

135 ibia., p. 72 .

136 odo et al., p. 224 .

137 Stanford M. Lyman, "Conflict and the Web of Group Affiliation in San Francisco's Chinatown", in The Asian American: The Historical Experience, Norris Hundley, Jr., editor, (Santa Barbara:Clio Press, Inc., 1976), (pp. 26-52) p. 29.

138 Blauner, p. 52 .

139 ibid., p. 53.

140 ibid., p. 37.

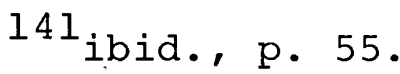

142 ibid., p. 56. 
143 Pei-Ngor Chen, "The Chinese Community in Los Angeles", Social Casework, LI, (December 1970), p. 595.

144 Blauner, p. 23.

$145_{\text {ibid., p. } 63 .}$

146 Alexander Saxton, The Indispensible Enemy: Labor and the Anti-Chinese Movement in California, (Berkeley:University of California Press, 1971), p. 5. See also Herbert Hill, "Anti-Oriental Agitation and the Rise of Working Class Racism", Society, X, (Jan./Feb. 1973), p. 44; and James I. Wong, Aspirations and Frustrations of the Chinese Youth in the San Francisco Bay Area: Aspersions Upon the Societal Scheme, (San Francisco: $R$ and $E$ Research Associates, 1977), pp. 59-60.

\section{Blauner, p. 61 .}

148 Bee, p. 47.

149 ibid., p. 44. See also Bee, pp. $26-27$ and pp. 51-52.

${ }^{150}$ Coolidge, table on "California Labor Exchange (18689)", p. 348 .

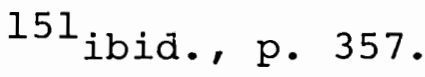

152 Blauner, p. 53 and p. 67 .

${ }^{153}$ Coolidge, p. 302 .

154 Blauner, p. 68 .

${ }^{155}$ Chia-lin Chen, "Chen Chia-lin's Translations (Articles Written by Portland's Chinese)", (unpublished manuscript, Oregon Historical Society, 1973), p. 19. From an article by Ai-hsin Wong in the Chinese Language School Quarterly, I, (August 1921).

$156_{\text {Nee, p. } 385 .}$ 
PART II

THE HISTORICAL EXPERIENCE OF THE CHINESE IN PORTLAND 
CHAPTER V

EARLY YEARS OF TḤE CHINESE IN PORTLAND, 1851-1880

THE ARRIVAL OF THE CHINESE IN PORTLAND

We have mentioned that the Chinese began to come to California around the time of the California gold rush. Evidently the first of these immigrants, two men and a woman, arrived in San Francisco aboard the Eagle from Hong Kong in February of $1848 .^{1}$ Coincidentally, this was just a few weeks after the discovery of gold at Sutter's Mill. Soon, thousands of Chinese were coming to California to mine gold.

The first Chinese in Oregon came here from California, and were miners looking for more fertile claims and less hostility from white miners. They began to appear in Oregon's southern counties in the early 1850's, and many began to arrive after gold was discovered in Jacksonville in $1852 .{ }^{2}$ By 1857, the Oregonian claimed there were one thousand to twelve hundred Chinese gold miners in Josephine County. ${ }^{3}$ In. 1862 gold was discovered in eastern oregon, and many Chinese also traveled from California to this area." By 1870 there was a large Chinese community in John Day, and also communities in Auburn, Granite, Union', and many other cities in eastern oregon. The Chinese miners often outnumbered the ite miners. 5 
Many of the Chinese miners who came to Oregon were fleeing from the hostility they had experienced from white miners in California. Chinese were driven off mining claims, beaten, and sometimes killed. Also, a tax on foreign miners, aimed at the Chinese, was passed in California during the 1850 's. ${ }^{6}$ By the $1860^{\prime} \mathrm{s}$, the mines in California were beginning to run out, and both white and Chinese miners were on the move to the Pacific Northwest.

Chinese also came to Oregon from California to work in the salmon canneries, starting in the 1870 's. ${ }^{7}$ Most of these canneries employed Chinese labor exclusively, because the work was so hard and the pay so poor that whites could not be found for the job. Edson Dow says that many Chinese also found the work too arduous, and left the canneries to become miners. ${ }^{8}$ Many of the cannery workers in Astoria and other areas along the Columbia actually lived in Portland, and worked in the canneries only part of the year, when the salmon were running.

\section{Arrival of Chinese in Portland}

Most sources say that the first Chinese came to Portland in the 1860's. However, an 1851 advertisement in the Oregonian for the Tong Sung Boardinghouse, on Second Street, indicates otherwise:

Mr. /S Sungsung? Tfrom China, would inform the public that he has opened a Boarding House and Restaurant, and, having first rate China cooks, can give good board and lodging to those who may favor him with their patronage. Private rooms for Gentlemen and 

suppers made up to order. A choice variety of
liquers constantly on hand.

Thus, Mr. Sung and several Chinese cooks, at least, were resident in Portland in 1851. The ad implies that his boardinghouse served whites rather than Chinese, so there is no indication that there were any other chinese in town. Mr. Sung is thus almost certainly the first Chinese to arrive in Portland, for Portland's first census, conducted in December of 1850 , indicated 817 white residents, four free blacks, but no Chinese residents. 10

There was also a Chinese named A Long, aged 19, who was a servant of Captain Rufus Ingle at the Vancouver Barracks in 1850.11

By 1857 there was a thriving Chinese community in Portland, most of whom arrived by way of California. Percy Maddux says that many Chinese arrived in that year on the steamer Columbia from San Francisco, and worked as cooks, gardeners and laundrymen. ${ }^{12}$ The Oregonian also records the arrival of Chinese in Portland in that year. ${ }^{13}$ Currier says that many Chinese fled from persecution in California in 1865, and quotes the Oregonian in May, 1866, as saying: "...the mean eyed pests are coming by every steamer, 200 arrived this week." 14

In 1868 the Chinese also began to arrive in Portland directly from China. The first of these evidently arrived in the French ship Jennie Alice, which brought 430 Chinese; 
both merchants and laborers, to Portland in August of that year. ${ }^{15}$ Many other ships followed.

We can assume that the earlier arrivals from California had established a Chinese community in Portland, and wrote their relatives and neighbors in China. Bessie Ying Lee observed that as of $1938,90 \%$ of the Chinese population in Portland was from a single district in China, Toishan. ${ }^{16}$

\section{STATISTICS ON CHINESE IMMIGRATION AND POPULATION}

Figures are available on Chinese immigration and population during this period, but their accuracy is questionable. Tsai observes that in the 1850's three different agencies came up with three different figures for the number of Chinese immigrants. ${ }^{17}$ Figures on Chinese population in the Portland directories invariably differ from those in U.S. census reports. There is also evidently a problem in finding the information. Chen and Currier both state that no Chinese are listed in Oregon in the 860 census. ${ }^{18}$ but such information is listed on page 405 of. the 1860 census.

\section{Chinese Population}

Population estimates often varied according to the point of view of the analyst. ${ }^{20}$ Anti-Chinese sources engaged in gross exaggerations of the number of Chinese in. this country. The chinese, however, were frequenty said to lie to census takers. in order to depreciate their numbers. 21 
Thus, the data which we provide in Table II (below) on the Chinese population in Portland and in Oregon must not be considered definitive. It does indicate, however, that by 1880 Portland already had a thriving Chinese community of 1668 members, which comprised $9.5 \%$ of the total population of Portland at that time.

TABLE II

CHINESE IN PORTLAND AND IN THE STATE OF OREGON, $1860-1970$

\begin{tabular}{|c|c|c|c|c|c|c|}
\hline \multirow[t]{2}{*}{ Year } & \multicolumn{3}{|c|}{ OREGON } & \multicolumn{3}{|c|}{ PORTLAND } \\
\hline & $\begin{array}{l}\text { Total } \\
\text { popula- } \\
\text { tion }\end{array}$ & Chinese & $\begin{array}{l}\text { \% Chinese } \\
\text { in total } \\
\text { population }\end{array}$ & $\begin{array}{l}\text { Total } \\
\text { popula- } \\
\text { tion }\end{array}$ & Chinese & $\begin{array}{l}\text { \% Chinese } \\
\text { in total } \\
\text { population }\end{array}$ \\
\hline 1860 & 52,465 & 425 & $0.8 \%$ & 2,874 & 22 * & $0.8 \%$ \\
\hline 1870 & 90,923 & 3,330 & $3.7 \%$ & 8,293 & 456 & $5.5 \%$ \\
\hline 1880 & 174,768 & 9,510 & $5.4 \%$ & 17,578 & $i, 668$ & $9 ळ \%$ \\
\hline 1890 & 317,704 & 9,540 & $3.0 \%$ & 46,385 & 4,539 & $9.8 \%$ \\
\hline 1900 & 413,536 & $5 \quad 10,397$ & $2.5 \%$ & 90,426 & 7,841 & $8.7 \%$ \\
\hline 1910 & 672,765 & 7,363 & $1.1 \%$ & $207,2 \cdot 14$ & 5,699 & $2.8 \%$ \\
\hline 1920 & 783,389 & 3,090 & $0.4 \%$ & $258,28.8$ & 1,846 & $0.7 \%$ \\
\hline 1930 & 953,786 & 2,075 & $0.2 \%$ & 301,815 & $\cdot 1,416$ & $0.5 \%$ \\
\hline 1940 & $1,089,684$ & 2,086 & $0.2 \%$ & $30: 5 \div 394$ & 69 & $-0.5 \%$ \\
\hline 1950 & $1,521,341$ & 2,102 & $0.1 \%$ & $373 ; 628$ & 467 & $0.4 \%$ \\
\hline 1960 & $1,768,687$ & 2,995 & $.0 \%$ & I & & \\
\hline 1970 & $2,091,385$ & 4,814 & $0.2 \%$ & 382,619 & 4.62 & $0.6 \%$ \\
\hline
\end{tabular}


Still, throughout the early history of the Chinese community in America, almost all Chinese lived in California, and the biggest single Chinese community was in San Francisco. Chen observes that in 1880, there were 105,465 Chinese in the United States. Of this number, 75,132 were in California; only 9,510 were in Oregon, which still made Oregon the state with the second largest Chinese population in America. 22

We can see from Table II that from 1860 to 1880 only a small percentage of all the Chinese in Oregon lived in Portland (5.2\% in $1860,13.7 \%$ in 1870 , and $17.5 \%$ in 1880). In 1890, however, the population of Chinese in the state changed hardly at all (from 9,510 in 1880 to 9,540 in 1890); while the Chinese population in Portland rose from 1,668 to 4,539 , so that nearly half $(47.6 \%)$ of the Chinese in the state lived in Portland. Thus, the Chinese in Oregon from 1860 to 1880 were mainly rural -- reflecting their activities in mining, and other occupations to be discussed later. After the mines ran out, and the railroads were finished, Chinese evidently congregated mọe in Portland.

\section{Chinese Immigration}

Figures on immigration are as contradictory as those for population. Melendy states that immigration of Chinese through San Francisco was high in the 1850's, leveled off in the 1860's, and then rose dramatically beginning in $1869^{23}$ (presumably due to the start of railroad construction). 
Currier states that from 1850 to $1869,138,586$ Chinese entered the country. (This figure is probably too high. Tsai's figures from the Bureau of Immigration say only 89,958 Chinese came here during this period. ${ }^{24}$ ) of these, 37,323 returned to China, and 10,420 died. ${ }^{25}$ Thus, not all the immigrants stayed in America, although most did. From 1869 through the imposition of the first exclusion law in 1882, Chinese arrivals in the United States totalled 203,283, according to Bureau of Immigration figures provided by Tsai. 26 We were unable to obtain any comprehensive information on Chinese immigration through Portalnd. Ben Maxwell provies data on six ships which arriving in 1869 and "within a few years thereafter," which brought 1,955 Chinese to Portland. 27 Fred Lockley states that in 1882 (just prior to the imposition of exclusion legislation), fifteen ships brought in a total of 9,351 Chinese. 28

\section{OCCUPATIONS OF EARLY CHINESE IMMIGRANTS}

We have mentioned that most of the Chinese immigrants were laborers. A few were merchants. Many. Chinese merchants in America arrived as laborers, but after years of working and saving were able to become merchants, shopkeepers or restauranteurs. ${ }^{29}$ (We are using the term "merchant" as a designation of social class, including any person who engages in business, as opposed to labor.) 
Tsai says that only one-eighth of the Chinese in America were merchants, ${ }^{30}$ but we shall see that they were the elite of the Chinese community. They had the money, and they had prestige and knowledge of American 1ife, as well as contacts with white Americans, which enabled them to make arrangements between the Chinese laborers and American employers, immigration officials, etc.

We have seen that probably the first Chinese in the city of Portland -- Mr. Sung, the boardinghouse operator -was a merchant. By 1873, Samuel's Portland Directory lists sixty-three Chinese businesses, all but one of which were in the Chinatown which was rapidly growing up along Southwest Second Street. Many of these businesses were aimed at Chinese, rather than white, clientele. Shopowners, Chinese druggists, and doctors, etc., which accounted for eighteen of the businesses listed presumably dealt mainly with supplying the needs of the Chinese community itself.

Other businesses dealt with the white community. There were thirty-seven Chinese laundries, a tailor, a clothing manufacturer, and a cigar factory. These businesses also provided employment for many of the Chinese laborers in the community. In addition, there were two labor contractors listed, who negotiated with whites who needed Chinese laborers, and then located workers to fit their clients'. needs. 32

Most of the Chinese were laborers. Their jobs were unskilled, menial, and usually in areas where they would not 
compete with whites. That is, Chinese cooks might work in

Chinese restaurants or in American homes, but not in Americanstyle restaurants that habitually employed white labor. ${ }^{32}$

Use of a labor contractor, who was usually a Chinese merchant who knew English, was a common way of employing Chinese. This was not a form of indenture or forced labor. The contractor had a great deal of power in the community, for he could decide who got what job; and could negotiate with the whites about pay, length of the contract, provision of room and board, etc. But he could not force a chinese to take a job he didn't want, and usually the contracts were not so rigid that a chinese could not quit if he didn't like the job. The labor contractor was really an agent of the laborers -- he found them work, and made sure that they were paid adequately for it. Many contractors did, however, make a lot of money for themselves out of these efforts.

Mr. George Roberts, a Californian who utilized Chinese labor in his business of reclaiming marshlands, testified before a Congressional committee in 1877 as follows:

Q. It is alleged that these men came under contract of service, voluntary contracts, but a species of slavery. The question I desire to ask is, whether, because they come like that, and that they work in droves, and contract through one man, does not account for the efficiency of their labor? -- A. I think that is a mistake; that there is nothing of that kind at all. I find my Chinamen entirely independent of the boss... If the boss does not pay them any wages they tie him up and call on us. That has been the case is several instances. I find that each man has his account, and he holds the boss responsible.

Q. Are these bosses Chinese? -- A. They are Chinese. 
We have seen that from 1850 to the 1880's most Chinese in Oregon lived in the rural areas. Even many Chinese who lived in Portland would at times take contract jobs in the canneries or on the railroads that would take them away from Portland for months at a time.

Tsai says that as of 1868 , two-thirds of the Chinese in America worked in either the railroads or in mining. ${ }^{34}$ Ping Chiu lists the two most common occupations of Chinese in 1880 as "common labor" and "miners." 35 Edson lists occupations for Chinese in five eastern counties of oregon in 1870 and 1880. Miners were predominant, being $49.8 \%$ of the labor force in 1880. There were no railroad workers in 1870 in this area, but by 1880 construction was going on in Wasco County, and railroad workers constituted $33.7 \%$ of the labor force. $^{36}$ These two occupations thus accounted for $83.5 \%$ of the labor force in eastern Oregon in 1880.

Both these occupations involved hard and unrewarding work. The Chinese miners were subject to special "foreign miners" taxes beginning in 1860 in Oregon, and after 1866 were prohibited from owning mining claims in this state. 37 The Chinese were able to get around these laws often enough, but because of the laws and the hostility of white miners, generally worked only the poorer claims and even the discarded tailings from white men's claims. ${ }^{38}$

Work on the Railroads 
Chinese were first used to build the railroads during the construction of the transcontinental railroad through California and Nevada from 1863 to 1868. The first Chinese were hired in 1865 after work had stalled and no white laborers could be found. They were at first paid twenty-five dollars a month (a dollar a day), which was the standard of the time for all unskilled labor, white and Chinese. After a time this was raised to thirty, and then thirty-five dollars. But the Chinese were required to work long hours, do the most dangerous work, and were still paid five dollars less than white workers.

In 1867, in the High Sierras, they struck for forty dollars a. month and an eight hour day, using the slogan "Eight hours a day good for white man, all the same good for Chinaman!" The strike failed when the construction superintendent cut off food to the Chinese, but the incident is significant because it was the first strike by Chinese workers, and an indication that Chinese were not quite as docile and uncomplaining as they were made out to be. 40

Chinese were involved in railroad construction work in Oregon from 1868 to 1888, on eight different lines: Around 15,000 Chinese in all were employed in these projects. ${ }^{41}$ These workers also worked under poor conditions: Chauncey Del French records an incident in which one of the white foremen on the construction of the Northern Pacific line was mobbed by his Chinese workers because food supplies had been 
late in arriving. ${ }^{42}$ Willis Nash, an Englishman who visited Oregon in 1880, writes of observing Chinese working on an Oregon Railway and Navigation Company line near the Dalles:

... we passed them hard at work, spread in a long line on the face of terrible rock, which looked as if five thousand Chinamen might work at it in vain for a year to make a fit passage for the train. But without them how would these great works get done. 43

Other Areas of Employment for Chinese

We have also mentioned that many Chinese worked in salmon canneries in Oregon. Many Portland Chinese worked in the Astoria canneries during the canning season, and there was also a sizable Chinese community in Astoria itself. Gordon Dodds says that George Hume introduced Chinese labor to the canneries in 1871, and calls this "an economic advance for employers because the Chinese were more reliable workers than Americans and were less prone to join labor unions. " 44

Dorothy Johansen says that by 1881 some thirty canneries on the Columbia employed about four thousand Chinese, who were paid a dollar to a dollar and fifty cents per day. 45 Corbett says that by $1880,31.4 \%$ of the Chinese were employed in the canneries. 46 The chinese were never allowed the more prestigious job of fishing: they only canned. 47 They worked long hours making the cans and packing the fish, and many employers cheated the Chinese by selling them bedding or supplies at inflated prices from company stores. 48 
Chinese in rural areas also worked in ranching, as seasonal farm laborers, and at clearing land.

Urban Employment of the Chinese

Chinese in the cities also worked at arduous and menial labor. Daniels and Kitano say:

Jobs that are generally regarded as women's work were among the earliest points of entry into the labor market for the Chinese...49

Daniel Feller provides information on the occupations of 1,435 Chinese in Portland in 1880. This presumably represents nearly the entire Chinese work force in the city at that time, for the total Chinese population was only 1,668 (see Table II). According to these statistics, $55.8 \%$ of the -Chinese were employed as laborers, 15.7\% as laundrymen, 12.5\% as cooks, $7.2 \%$ as domestics; and the remaining $8.7 \%$ in mercantile employment. ${ }^{50}$ Feller also provides some interesting figures on the penetration of Chinese into various occupations. According to these statistics, in Portland in 1880, $99 \%$ of the laundrymen were Chinese, $76 \%$ of the domestics were chinese, $74 \%$ of the cooks were Chinese, and Chinese held $45 \%$ of the positions in the occupations "laborer" and "tailor." 51

Generally, Chinese did not compete with whites; doing menial jobs that supposedly were below the dignity of white Americans. One white immigrant group, however -- the Irish -did engage in some of the same occupations as the Chinese. 
For example, 56\% of the Chinese were laborers, and $40 \%$ of the Irish were also laborers, 52 Dorothy Johansen says that:

A perennial shortage of domestic help plagued Portland housewives when even their Irish maids deserted them to marry. In the seventies the Irish comprised the largest foreign-born group in Portland; but within a decade, "China boys" became the laundrymen, ghardeners, houseboys, and chefs for the well-to-do. 53

We have little information on Chinese being employed in manufacturing in Portland, although we know that in California Chinese were often employed in cigar factories, woolen mills, and clothing factories. ${ }^{54}$ We have seen that many Chinese in Portland were tailors, and that there was a Chinese-operated cigar factory in Chinatown as of 1873. Some Chinese were also employed in woolen mills in Oregon City as early as 1868.55

In general, however, the Chinese in Portland and in Oregon were employed in the "preindustrial" sectors of the economy (as defined in the last chapter). They worked long hours, under poor conditions, and for low wages. They were not paid less than whites doing similar work. ${ }^{56}$ When they were, they complained vigorously, as we saw in the case of the strike on the transcontinental railroad. But they worked in areas of employment which were generally unattractive or demeaning to. white Americans.

REACTION OF THE WHITE POPULATION TO CHINESE IMMIGRATION

We have seen that Chinese laborers were initially welcomed and encouraged to come to América's West coast because 
of the need for cheap labor. The Asian American Task Force of the Council on Social Work Education states that:

Historically, America has tolerated and in some instances even welcomed minorities to the country during times of special need. Generally, this has consisted of a need for cheap labor... Yet, when these needs were met and the minorities began to compete for work with whites, individual and institutional acts of racism came out in the open. 57

In Oregon, there was perhaps less of a "Chinese problem" than in California, because oregon developed industrially later than California and thus had a need for its Chinese preindustrial labor well into the 1880's and $90^{\prime} \mathrm{s}$, which was the period of greatest anti-Chinese hostility. Also, oregon had a smaller body of white laborers and immigrants than California or Washington; and it was this population of floating wage earners that formed the anti-Chinese mobs of the 1880 's. 58 Also, many leaders in this state, most notably Harvey $W$. Scott, editor of the Oregonian, continuously spoke out against anti-Chinese agitation. 59

This is not to say, however, that there was no hostility against the Chinese in Oregon; such hostility existed from the first arrival of the Chinese. But it took place at a lower level, and with less outright violence, than was the case in neighboring states.

Even in California, which became the area of the most intense anti-Chinese agitation, the Chinese were originally welcomed. The Alta California editorialized in 1850 that the Chinese were "very useful, quiet, good citizens...deserving 
of the respect of all."60 And California's first two governors both referred favorably to the chinese in their annual messages. 61 Daniels and Kitano say of the Chinese, upon their first arrival in California:

The Chinese were naturally objects of curiosity, but since they were willing to provide supplementary rather than competitive economic seryices, there was little or no objection to themb

The Beginnings of Hostility Towards Chinese

This situation changed when Chinese were seen as competing with whites in the mine fields. We have seen that restrictive legislation, in the form of foreign miners taxes and prohibitions on owning mining claims were instituted in California; and that in 1860 and 1866 similar provisions were passed in Oregon. Hostility against the Chinese in both California and Oregon first appeared in the mining districts. When the Canyon City, Oregon, Chinatown burned down in 1885, for instance, the Chinese were not allowed to rebuild and were forced to move to John Day. ${ }^{6}$ And Peters and Powers write of Powers, Oregon, in Coos County, that

There were Chinese mining here when the settlers came... The settlers were more afraid of the chinese than they were of the Indians. Finally they decided they could get along very well without the Chinese who were very superstitious, so it was an easy task for the settlers to scare them out. 64

The Situation in Urban Areas

Life was somewhat better for the Chinese in urban areas, but still there was hostility against them. David 
Colton, vice-president of the Southern Pácific Railroad, testified at the 1877 Congressional hearings that:

I have seen quiet, peaceful Chinamen going through the street, when grown men would hit them in the face, knock off their hats, and do all those things which, if done to an American in China, the whole American nation would be in favor of war...65

Colton referred to the situation in California, but similar incidents occurred in Portland. Judge Matthew Deady observed in his diary that, at a fire in Chinatown in 1872,

The poor chinamen were cruelly abused by the Fenian Guards /D̄eady's term for the Emmett Guard, an allIrish guard of the Oregon militia7 and the street Arabs upon pretense of making them work the engines. 66

And Percy. Maddux oberved that in Portland:

Boys and even grown men threw stones at the Chinese and called them names. There are Portlanders still living who can remember when boys threw snowballs at the Chinese or tailed after them hooting, "Chink, Chink, Chinaman!" There were times when lone Chinese feared to stray very far, especially at night, from the Chinatown that was growing up on second Street. 67

Anti-Chinese Organizations

The strongest anti-Chinese sentiments arose when the Chinese were seen as entering white areas of employment. In the 1860's, anti-Chinese agitation began to take on an organized form. In April of 1867, a mass meeting in Lake Oswego passed a resolution against Chinese being employed by the Oregon Iron Company. ${ }^{88}$ In Oregon City a mass meeting passed a resolution in January of 1869 condemning the employment of Chinese by the Oregon City Woolen Manufacturing Company. White workers struck the plant in July of the same 
year to protest Chinese employment, but were merely replaced by Chinese. 69

In June of 1873 the Oregon Anti-Chinese Association, also called the American Protective Alliance, was formed in Portland, and soon had over a hundred members and a branch in Oregon City. A fire in the Portland business section was blamed on this organization; employers received threatening letters warning them not to hire Chinese; and the Oregonian claimed the organization was linked to the Ku Klux Klan. 70

Political and Legal Discrimination

Politicians began to support the anti-Chinese elements. LaFayette Grover, in his successful campaign for Governor of Oregon in 1870, made "Chinese cheap labor" an issue, and claimed that the Chinese "add nothing to the wealth of the country." 71

Anti-Chinese legislation began to be popular; Currier says that during the late 1860's "The whites crammed their statute books with restrictive acts planned to make life in America impossible for the Mongolians."72 But most of these laws were struck down as a violation of the Burlingame Treaty in 1868 .

Judge Deady wrote in his diary of several court cases during this time. One 1875 case dealt with two Chinese accused of selling liquor to Indians, and Deady says:

Verdict of guilty. Chinamen guilty I have no doubt but I do doubt whether the jury would have found a white man guilty on the same evidence...73 
In 1879 Deady struck down a Portland ordinance prohibiting Chinese labor on public works and streets. ${ }^{74}$ In both California and Oregon, state constitutions prohibited Chinese from testisying in court against whites. Mark Twain commented:

Ours is "the land of the free"-- nobody denies that-- nobody challenges it. (Maybe it is because we won't let other people testify.) $75^{1}$

Some whites in Portland did speak up for the Chinese, however. We have already mentioned that the oregonian consistently condemned anti-Chinese agitation, and defended Chinese labor as an essential element in the development of Oregon. Rev. J. A. Gruzan of the Congregational Church in Portland published a sermon in the 1870's advocating application of the Golden Rule to the Chinese and defending them against allegations of immorality. He said:

Morally John /i.e. the Chinese 7 is not a saint. He is very black indeed. But he finds plenty of 76 company among our native and foreign population. 76

A letter in the Oregonian in 1861 by "A. Boston" supported the presence of the Chinese. 77 And another letter from a Chinese merchant, Tong Duck Ching, said: "Don't want to infringe on any of your laws, only want equality before the law." 78

THE CHINESE COMMUNITY IN PORTLAND.

We do not have much information on the early days of the Chinatown in Portland. We do know that the original 
Chinatown took up the first four blocks on Southwest second as far as Oak. 79 This was the "Old Chinatown." A new Chinatown grew up in Northwest Portland around 1900. Sidney Warren says that:

Portland's Chinatown in the early eighties contained about twelve thousand Orientals /census figures say less than two thousand 7 wo were employed as seasonal workers in the canneries and mills, on the railroads, as laundrymen, barbers, and domestics. It was crowded with exotic shops and bazaars, laundries, fish markets, and restaurants over which wooden awnings had been built as protection from the rain. The streets were constantly filled with loitering Chinese males, gossiping or shopping while the smoke from their tiny-bowled, enormously long-stemmed pipes hung overhead. 80

Figures 2 and 3 are the earliest photos we were able to locate of the old Chinatown, but neither of them was taken prior to 1880. We have no comprehensive data on the life style of the Chinese from 1850. to 1880 , or on their community organizations.

The Formation of "Chinatowns"

We have alluded to the fact that. Chinatowns formed as a result of both white hostility and discrimination, and the desire of the Chinese for the mutual support offered by an enclosed community. Chia-lin Chen says that:

"Chinamen" in this land were known for their clannishness and gregariousness; for wherever there were. considerable numbers of Chinese there existed also a Chinatown. It was quite true that they were clannish... But it was not necessarily true that they were gre-garious. In fact, a Chinatown was a product of segregation caused largely by whites. 81 

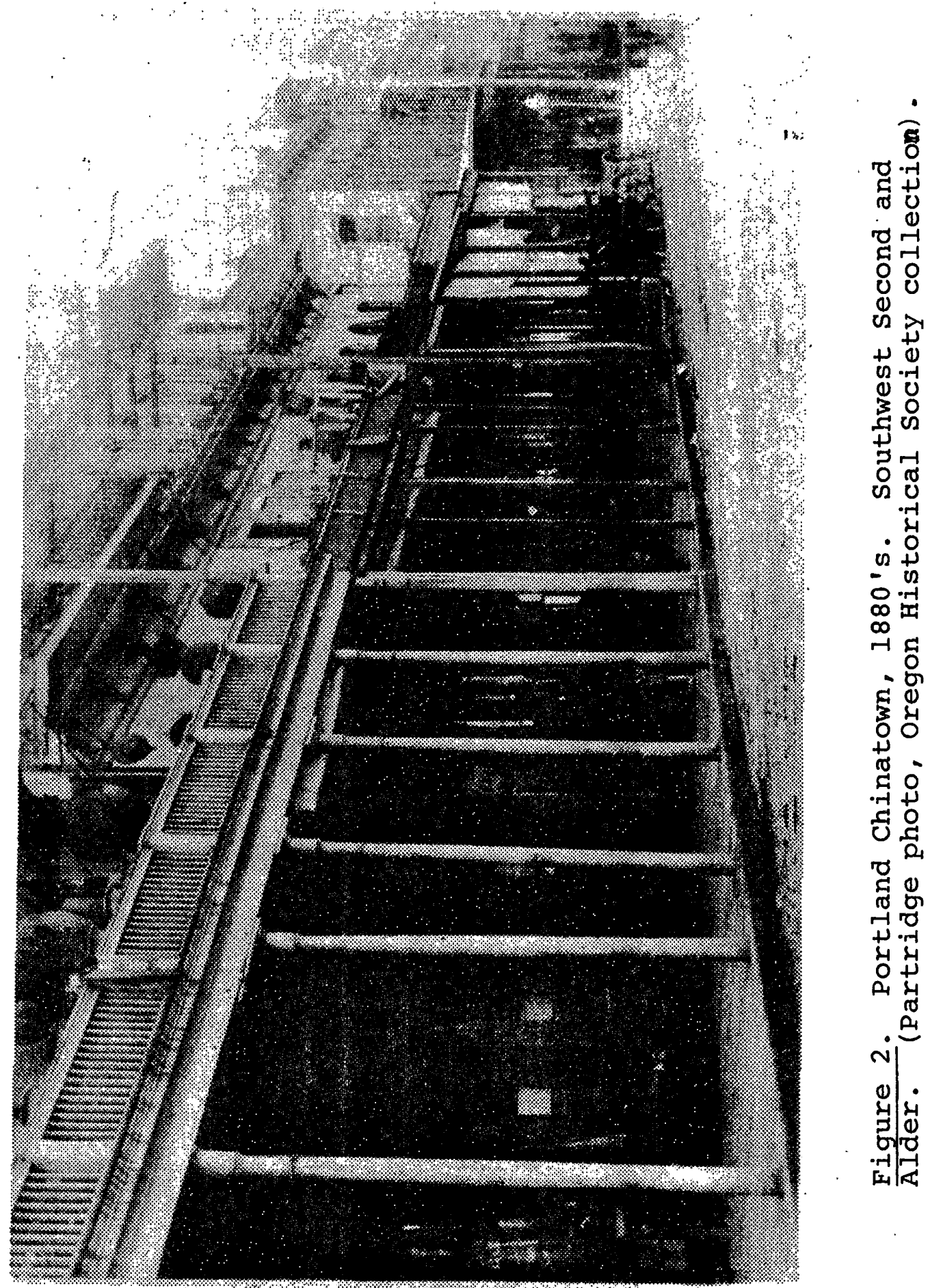


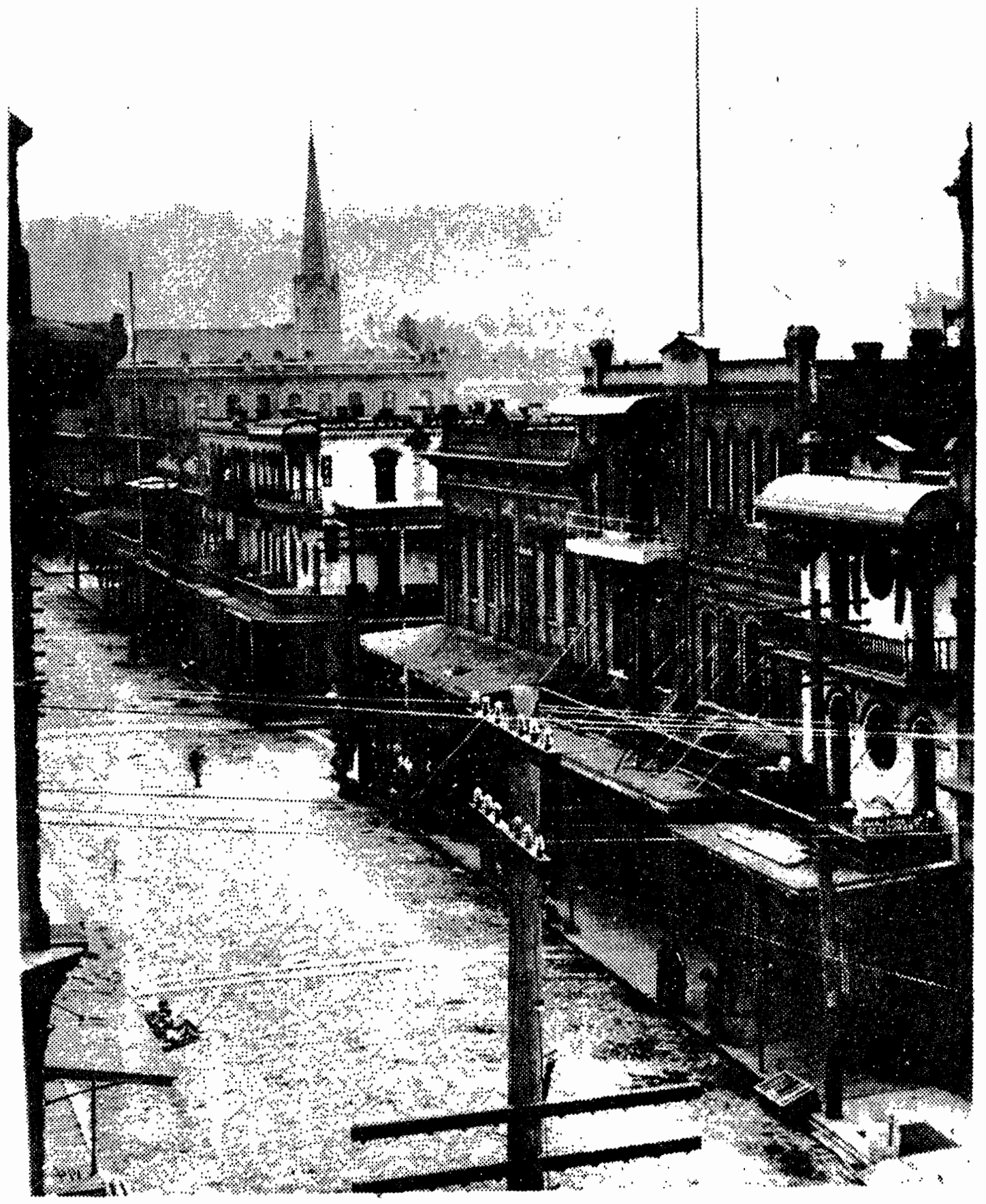

Figure 3. Portland Chinatown, c. 1890. Second Street, looking south to Washington (Oregon Historical Society collection). 
But Chen also notes that "The segregation from whites was accepted tacitly by Chinese, for it also served their needs, particularly the need of safety." 82 chen lists a number of factors which contributed to the existence of Chinese communities; we feel that Chen's analysis is quite useful and comprehensive.

First, Chen points out that in any given community, many Chinese were likely to come from the same family or the same district in china. ${ }^{83}$ The first arrivals in a town in America would write to their family and friends back home, and others would follow, naturally looking for a place to locate in America where there were already familiar faces and a common dialect. We have seen that most chinese in Portland came from the area around Toishan and Hoy Yin; and many Chinese in Portland also came from the same clan, the Wongs being the most common.

second, the all-male society contributed to a need for togetherness. Chen says that "Restlessness and fear of being alone are great forces that drive bachelors to seek company. " 84

Third, the Chinese laborer, being a sojourner with intentions of eventually returning to China, had no desire to amalgamate with American society. He wished to live, as nearly as possible, the way he had lived in China. ${ }^{85}$ Chinatown offered a place with familiar food, language, and customs; and sanctuary from the confusing habits of the Americans. 
Also, Chinatown afforded job opportunities to the Chinese. There were jobs within Chinatown itself-- in the restaurants, laundries, cigar factories, etc. And there was the labor contracting system which provided jobs outside the community-- in the canneries, on the railroads, as domestics, and so forth. Chen says:

...the confusion of Chinese laborers upon their arrival and stay here must have been tremendous... All they could do was stay and wait in Chinese communities, and let their fellow countrymen, who had been here earlier and had gained much experience, help them and furnish them with news about job opportunities. 86

There were also disadvantages to the "Chinatown" system. The isolation of the Chinese in segregated areas made them seem mysterious and aloof, made their numbers seem larger, and added to white hostility. Their job opportunities were restricted to those jobs traditionally open to Chinese. Vice, in the form of opium, prostitution, and gambling, was able to flourish in the enclosed atmosphere of Chinatown. Competition between Chinese, was made more noticeable and more intense. ${ }^{87}$

\section{Chinese Organizations}

From the time of the arrival of the first Chinese in America, organizations began to spring up in the larger Chinese communities; notably San Francisco. We unfortunately have only a little data on Chinese organizations in Portland before the turn of the century. We have seen that many whites of the time saw such organizations as having absolute control 
over Chinese labor through debt bondage and through quasigovernmental control structures in Chinatown. In actuality, these organizations did have some social control functions, particularly in the area of employment; but their primary purposes were protection and mutual support.

Stanford Lyman has observed that:

Chinese communities in the United States have enjoyed a measure of isolation and communal selfgovernment far exceeding that of other ethnic communities. One reason for the unusual separation of Chinatowns from regular public municipal controls was their long period of electoral irrelevance to American politics. 88

Various types of organizations developed in these Chinese communities, most of them modeled on community organizations; e.g. organizations of people coming from the same town or district. Melendy says that such organizations of sojourners from other areas existed in many cities in China. ${ }^{89}$ Other organizations that existed in China and were transferred to the United States include clan associations, trade guilds, and secret societies. 90 we have mentioned earlier the functions of clans and the secret societies in China. Trade guilds had functions similar to both unions and owner's associations in America, and were made up of both employers and employees belonging to a particular trade. The first Chinese organizations in America were district associations formed in San Francisco. In November, 1849, less than two years after the first arrival of Chinese in California, the first meeting of San Francisco's Chinese 
residents was held, and an organization formed. 91 soon, this split into several factions as the number of Chinese in San Francisco increased dramatically. By 1854 there were five district associations, or "companies," in San Francisco. In 1867 they were joined by a sixth company. In 1862 the companies joined together to form an arbitration and coordinating council of all these groups, which came to be known as the "Chinese Six Companies," but was officially called the Chinese Consolidated Benevolent Association (CCBA). 92 This organization served as the model for Chinese organizations in other cities.

These companies had various functions. As we have mentioned, one such function was social control. First, the CCBA was the arbitrator of differences between the various Chinese organizations which made up its membership. For a time, the California district association had many disputes, sometimes violent, among themselves. ${ }^{93}$ The CCBA provided a structure for peaceful resolution of such disputes, and also enabled the Chinese community to speak to white America, through the CCBA, with a united voice. ${ }^{94}$ The companies also arbitrated disputes between individuals.

The companies made sure that the Chinese laborers paid their debts, such as those incurred through the credit-ticket system, or through loans from other Chinese, etc. ${ }^{95}$ But we believe they were not engaged in the control and enslavement of Chinese labor, as Barth and others have claimed. 
Coolidge stated that:

...all the reputable Chinese and Americans who knew either the language or the Chinese population in the United States intimately, unite in testifying that the Six Companies are benevolent organizations, 96 exercising extensive advisory but no coercive powers. 96

Testimony at the 1877. Congressional hearings supported this, 97 and the Six Companies themselves issued a statement to this effect in a memorial to Congress in 1877.98 There is little evidence to favor Barth's point of view. But anti-Chinese elements persisted in insisting that the CCBA enslaved the Chinese, and most white Americans during this period believed such propaganda.

The Chinese organizations also had various protective functions. They attempted to intercede with white authorities on behalf of chinese whenever they could. The Six Companies memorialized Congress several times. They also arbitrated disputes between Chinese organizations and individuals, as we have seen.

But the Six Companies were controlled by wealthy Chinese merchants, and some of the laborers were at times unhappy with such arbitration. The tongs, which (as we saw in chapter III) were in China secret revolutionary societies, in America were originally laborers' organizations which protected these people from arbitrary exercises of power by the Six Companies. ${ }^{99}$ The tongs also soon gained control of the Chinatown vices-- drugs, prostitution and, most of all, gambling. 
Most importantly, however, all Chinese organizations provided mutual support to their membership in the form of various social and benevolent services. The district and clan associations cared for the indigent and unemployed; acted as an employment agency and bank for Chinese laborers; forwarded letters to isolated miners; provided cheap temporary room and board; shipped bones of the dead back to China; and put up rewards for murderers or thieves who victimized their members. 100

\section{Organizations in Portland}

We have no record of district or clan associations in the early days of Portland's Chinese community. There is an account in the 1861 Oregonian of Chinese filing court cases against each other, which states:

It seems as though the ancient feuds existing between the rival Chinese houses, the Cantons and Hong Kongs, have spread among their representatives in this city. 101

We cannot say whether this somewhat cryptic comment means there were district associations in Portland at this time. In the 1870's there was evidently some tong activity in Portland. Another note in the Oregonian tells of a Chinese man who helped a prostitute in Astoria escape and then married her. The "May Look" and "Fay Young" companies in Portland attempted to regain the girl, and had the man arrested; but he was acquitted. 102 
A. Chinese theater was opened in $1873 ;^{103}$ and there is a record of the incorporation of a "Gee Tong Kong Society" in Portland in 1879. ${ }^{104}$ We have no idea what this latter society was.

\section{Chinese Missions and Temples}

Most Chinese organizations of this period, however, seem to have been religious in nature. There were several Chinese temples, or "Joss Houses," as they were called. Two were opened in Portland in 1867. 105

Several Chinese missions and schools also began activities. The expressed purpose of these missions was to convert the Chinese to Christianity; but actually their primary effect was to provide English lessons to many Chinese. Forty Chinese attended English classes in the basement of the Methodist Church in 1869, 106 and the YMCA opened a Chinese school that same year. ${ }^{107}$ In 1873 a Chinese School was opened at St. Helen's Hall with seven teachers and an enrollment of thirty-five. ${ }^{108}$. At the same time, the American Missionary Association opened a Chinese mission at Main and Fifth, run by Miss M. P. Stewart. 109 And shortly thereafter, the Taylor Street Methodist Episcopal Mission opened a Chinese Sunday School under the management of J.F. Jones, with an average attendance of thirty-five. 110

None of these missions were to last too long, but in 1874 the Portland Chinese Mission School was opened by the First Baptist Church. The next year Dong Gong, a Chinese 
minister from San Francisco, came to Portland and was ordained as the pastor of the Chinese Baptist Mission in Portland. In 1879 a Chinese Chapel was dedicated at Fifth and Alder by Revs. Dong. Gong and Quin Chew. The Chinese Baptist Church is still in existence today, and is the fargest and oldest of four Chinese churches currently operating in Portland. 111

Leadership of the Portland Chinese Community

We will speak more of these missions in the next chapter. But before closing this chapter, we would like to emphasize that, as in San Francisco, merchants were the most prominent leaders in the Portland Chinese community. Two of the richest and most influential of these leaders began their careers in the 1850's and 60's. May Back Hin came to Portland in 1857 as a laborer, and by the turn of the century was a rich man and a community leader who was made the chinese Consul in Portland in 1906. 112 seid Back, Sr., was an important leader, grocery owner, and labor contractor in the Chinatown of the nineteenth century, and came to Portland in 1868. His son was also influential in the Chinese community in the early 1900's, and formed the first organizations of second generation Chinese in Portland. 113.

We have now reviewed the history of the arrival of the first Chinese in Portland, their occupations, and something of their lifestyle. In Chapter VI we will turn to the period 
of intense anti-Chinese agitation and exclusion, from 1880 to 1905. 


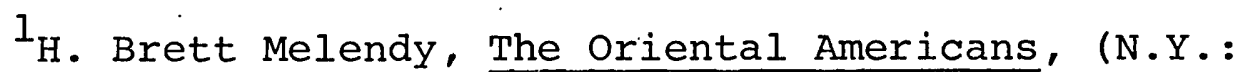
Twayne Publishers, Inc., 1972), p. 13; and Gunther Barth, Bitter Strength: A History of the Chinese in the United States, 1850-1870 (Cambridge, Mass.: Harvard University Press, 1962), p. 48 .

2 Viola Noon Currier, "The Chinese Web in oregon History," (Masters thesis, University of Oregon, 1928) p. 23 .

p. 2 c. 3 .

3"From Southern Oregon," Oregonian, Oct. 31, 1857,

4 Melendy, p. 44; and Chia-lin Chen, "A Gold Dream in the Blue Mountains; a Study of the Chinese Immigrants in the John Day Area, Oregon, 1870-1910," (Masters thesis in History, Portland State University, 1972), p. 75.

${ }^{5}$ Christopher Howard Edson, The Chinese in Eastern Oregon, 1860-1890, (San Francisco: $\mathrm{R}$ and E Research Associates, 1974), Table.2, "Proportion of Chinese Miners to White Miners in the Eastern Counties of Oregon, 1870," pp. 34-35.

${ }^{6}$ ibid., p. 8 .

${ }^{7}$ Currier, p. 42; and Edson Dow, Passes to the North: History of the Wenatchee Mountains (Wenatchee, Wash.: Outdoor Publishing Co., 1963), p. 50.

${ }^{8}$ Dow, p. 50 .

${ }^{9}$ Advertisement, Oregonian, Dec. 6,1851, p. 3.c. 4.

${ }^{10}$ Henry E. Reed, "Portland's First Census," (unpublished manuscript, Oregon Historical Society, MSS 383, Box 3).

${ }^{11}$ Karen $C$. Wong, Chinese History in the Pacific NorthWest, (privately printed, LSeattle? 1972 ), p. 29.

12 Percy Maddux, City on the Willamette: The Story of Portland, Oregon, (Portland: Binfords and Mort, Publishers, 1952), p. 78 .

13"Celestials," Oregonian, March 14, 1857, p. 2 c. 2. ${ }^{14}$ Currier, p.:28. 
${ }^{15}$ Fred Lockley, History of the Columbia River Valley, (Chicago: S.J. Clarke Publishing Co., 1928), Volume I, p. 544; and Ben Maxwell, "The Chinese in Salem," Marion County History, VII, (December 1961), p. 9.

16 Bessie Ying Lee, "Perpetuation of Primary Group Patterns Among the Chinese in Portland, Oregon." (Masters thesis in Sociology, University of Oregon, 1938), p. 35.

${ }^{17}$ Shih-Shan Henry Rsai, "Reaction to Exclusion: Ch'ing Attitudes Toward Overseas Chinese in the United States, 18481906," (Ph.D. dissertation in History, University of Oregon, $1970)$, p. 104 .

${ }^{18}$ Chen, p. 34; and Currier, p. 22.

${ }^{19}$ U.S. Department of Commerce, Bureau of the Census, Population of the United States in 1860. Eighth Census, (Washington: Department of Commerce, 1860), p. 405.

${ }^{20}$ Chen, p. 49.

${ }^{21}$ oregonian, City Column, Oct. 7,1865, p. 3 c. 1 . p. 57.

${ }^{22}$ Chen, Table I, "The Chinese in the United States,"

23 Melendy, p. 22.

24 Tsai, Table I, "Chinese Arrivals in the United States, 1852-1884," p. 105.

25

Currier, p. 21 .

26 Tsai, p. 105.

27 Maxwell, pp. 9-10.

28 Lockley, p. 545.

29 Tsai, p. 100.

${ }^{30}$ ibid., p. 106.

${ }^{31}$ Samuel's Portland Directory, (Portland: Geo. H. Himes and Co., Printers, 1873), pp. 341-342.

${ }^{32}$ Chen, p. 53.

${ }^{33}$ Frederick A. Bee, The Other Side of the Chinese Question-- Testimony of California's Leading Citizens, (San FranCisco: Woodward and Co., Printers, 1888; reprint ed., San Francisco: R and E Research Associates, 1970), p. 27. 
34 Tsai, p. 106.

${ }^{35}$ Ping Chiu, Chinese Labor in California, 1850-1880, (Madison, Wisc.: University of Wisconsin, 1963), Table 18, "Major Occupations of Chinese in 1880," p. 65.

${ }^{36}$ Edson, p. 54, and Table 4, "Occupations of Non-Mining Chinese in the Eastern Counties of Oregon, 1870 and 1880," p. 56. Edson's percentages of miners to total work force on p. 54 do not include figures for Wasco County. We have included these figures in our calcuations, and therefore our percentages are different than those in the table cited.

37 ibid., pp. 45-46.

38 ibid., p. 19 ; and D. W. Meining, The Great Columbia Plain, (Seattle: University of Washington Press, 1968), p. 234 .

${ }^{39}$ Melendy, pp. 44-46.

40 ibid., p. 46; and Wei Min She Labor Committee, Chinese Working People in America, .(San Francisco: United Front Dress, 1974), p. 15.

${ }^{41}$ Currier, p. 31. See also Dorothy O. Johansen, Empire of the Columbia, (N.Y.: Harper and Row, Publishers, 1967), p. 311 .

42 Chauncey Del French, Railroadman, (N.Y.: MacMillan and Co., 1938) pp. 94-95.

43 Willis Nash, Two Years in Oregon, (N.Y.: D. Appleton and Co., 1882), p. 204 .

44 Gordon B. Dodds, The Salmon King of Oregon, (Chapel Hill, N.C.: University of North Carolina Press, 1959) p. 6.

45 Johansen, p: 406 .

${ }^{46} \mathrm{P}$. Scott Corbett and Nancy Parker Corbett, "The Chinese in Oregon, c. 1870-1880,", Oregon Historical Quarterly, LXXVIII (March 1977), p. 82 .

47 Johansen, p. 46; and Steward A. Holbrook, The Columbia, (N.Y.: Rinehart and Co., Inc., 1956) p. $23 \overline{9}$

48 Dodds, p. 29.

49 Roger Daniels and Harry H. L. Kitano, American Racism: Exploration of the Nature of Prejudice, (Englewood Cliffs, N.J.: Prentice-Hall, Inc., 1970) p. 36.' 
${ }^{50}$ Daniel M. Feller, "Get a Job: Occupational Structure and Social Mobility in Portland, Oregon, 1960-1880," (Bachelors thesis in American Studies, Reed College, 1972), Table IV, "Chinese Males in Eight Selected Occupations, 1880." p. 76. See also Corbett, p. 77.

${ }^{51}$ Feller, Table $\mathrm{V}$, "Males in 40 selected occupations by Ethnic Groups, 1880," pp. 78-79.

52 ibid., p. 88 .

53 Johansen, p: 285.

54 Wei Min She; pp. 19-21.

55 Alfred L. Lomax, Pioneer Woolen Mills in Oregon, (Portland; Binfords and Mort, Publishers, 1941), p. 237.

${ }^{56}$ Bee, p. 70 .

57 Asian American Task Force, Council on Social. Work Education, Asian American fask Force Report: Problems and Issues in Social Work Education, (N.Y.: CSWE, 1973), pp. $6-7$.

${ }^{58}$ Chen, p. 37; and F. G. Young, "Why Oregon Has Not Had an Oriental Problem," Annals of the American Academy of Political and Social Science, XXXIV (July-December, 1909), pp. 307-308.

59

${ }^{9}$ Chen, p. 37.

${ }^{60}$ Victor G. and Brett De Bary Nee, Longtime Californ': A Documentary Study of an American Chinatown, (N.Y.: Pantheon Books, 1973), p. 33.

${ }^{61}$ Chen, p. 26 ; and Barth, p. 136.

62 Daniels and Kitano; p. 35. See also Mary Roberts Coolidge, Chinese Immigration, (N.Y.: Henry Holt and Co., 1909; reprint ed., N.Y.: Arno Press and The New York Times 1969), p. 22 .

\section{${ }^{63}$ Currier, p. 66 .}

64 Emil R. Peterson and Alfred Powers, A Century of Coos and Curry, (Portland: Binfords and Mor $\overline{t,}$ Publishers, 1952), pp. 127-128.

${ }^{65}$ Bee, p. 46 . 
${ }^{66}$ Malcolm Clark, Jr., Pharisee Among Philistines: The Diary of Judge Matthew Deady, (Portland: Oregon Historical Society, 1975), Vol. 1, p. 104.

67 Maddux, pp. 78-79.

68 Oregonian, April 10, 1867, "Protest Against Chinese Labor," p. 2 c. 3 and City Column, p. 3 .c. 1.

${ }^{69}$ Lomax, pp. 236-240

${ }^{70}$ Currier, pp. $43-45$.

${ }^{71}$ Leslie M. Scott, History of the Oregon Country, (Cambridge, Mass.: Riverside Press, 1924), Vol. 1, p. 81.

${ }^{72}$ Currier, pp. 41-42.

73 Clark, p. 190.

74 ibid., p. 283.

${ }^{75}$ Cheng-tsu Wu, editor, "Chink!", (N.Y.: World Publishing, 1972), p. 4. Wu documents prejudice against the Chinese by providing texts of discriminatory legislation; excerpts from books, speeches, memoirs, and grammar school textbooks; accounts of violent acts against the Chinese; and evidence of the continuation of discrimination today.

76 J. A. Gruza, "John Chinaman, How Did He Get Here?-What Kind of an Animal Is He?-- What Shall We. Do With Him?", (Oregon Historical Society Scrapbook, SB 80, p. 58, c. 1870's). c. 3 .

77 A. Boston, letter in Oregonian, March 25,1861, p. 2

${ }^{78}$ Tong Duck Ching, letter in Oregonian, July 24, 1869, p. 3 c. 1 .

${ }^{79}$ Bessie Ying Lee, p. 39.

${ }^{80}$ Sianey Warren, Farthest Frontier, (N.Y.: MacMillan and Co., 1949), p. 149 .
${ }^{81}$ Chen, p. 66 .
82 ibid., p. 68.
83 ibid., p. 69.
84 ibid., p. 70. 


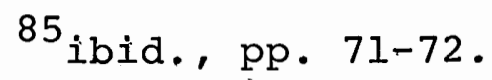

86 ibid., pp. $72-73$.

87 ibid., p. 74 .

${ }^{88}$ Stanford M. Lyman, "Conflict and the Web of Group Affiliation in San Francisco's Chinatown, 1850-1910," in The Asian American: The Historical Experience, Norris Hundley, Jr., editor, (Santa Barbara: Clio Press, Inc., 1976; pp. 26-52), pp. 28-29.

${ }^{89}$ Melendy, p. 71.

${ }^{90}$ Coolidge, p: 403. See also Nee, pp. 63-66; and Lee, pp. 9-13.

91

${ }^{1}$ Barth, p. 87 .

92 ibid., p. 97; and Melendy, pp. 73-74.

93 Barth, pp. 93-96.

94 Melendy, p. 74.

95 ibid., p. 73 .

${ }^{96}$ Coolidge, p. 406 .

97 Bee, pp. 20-22.

${ }^{98}$ Six Chinese Companies, Memorial; An Address to the Senate and House of Representatives of the United States, (San Francisco: Six Chinese Companies, 1877; reprint ed., San Francisco: $R$ and $E$ Research Associates, 1971), pp. 12-13.

${ }^{99}$ Lyman, pp. 39-40.

${ }^{100}$ Currier, pp. 18-19; Melendy pp. 72-73; and William Speer, "Democracy of the Chinese," Harper's New Monthly Magazine, XXXVII (November 1868), pp. 845-847.

p. 3 c. 1 .

101 "The Chinese and the Courts," Oregonian, Dec. 9, 1961,

102 oregonian, City Column, Nov. 7, 1877, p. 3 c. 1 . 103 oregonian, City Column, Jan. 23, 1873, p. 3 c. 3. 104 Samuel's Portland Directory, 1880, p. 52. 
${ }^{105}$ Oregonian, City Column, July 27,1867, p. 3 c. 1; and City Column, Sept. 24, 1867, p. 3 c. 2 .

106 oregonian, City Column, p. 3 c. 1, Oct. 12, 1869.

107 "The Fact Is," by Fred Lockley, Oregon Journal,

March 5, 1935, p. 6 c. 4-5.

108 oregonian, City Column, Feb. 11, 1873, p. 3 c. 1. ${ }^{109}$ Oregonian, City Column, Feb. 13, 1873, p. 3 c. 1. 110 oregonian, City Column, March 21, 1873, p. 3 c. 2 .

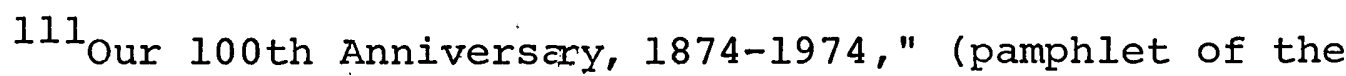
Chinese Baptist Church, Portland, 1974). See also the following articles in the Oregonian: "Ordination of Chinese Minister," June 23,.1875, p. 3c. 2; and "Chinese Chapel Dedication," Sept 16, 1879, p. 3 c. 3.

112 Chia-lin Chen, "Interviews with some Prominent Members of the Portland Chinese Community," (unpublished manuscript, Oregon Historical Society, 1973), p. 17.

113 Joseph Gaston, Portland, Oregon: Its History and 1 Builders, (Portland: S. J. Clarke, 1911), Vol. III, pp. 347348 . 
CHAPTER VI

EXCLUSION AND PERSECUTION OF CHINESE, 1880-1905

THE CAUSES OF ANTI-CHINESE HOSTILITY

We have seen that there was some agitation against the Chinese even from the time they first arrived in the United States; and such activities intensified in the 1870's. But the 1880's was the time of most extreme anti-Chinese hostility. The first exclusion laws were passed, and riots killed many Chinese, destroyed much property, and drove Chinese away from their homes all over the west.

\section{Social and Economic Factors}

Such extreme examples of racism were a result of several economic and social factors in the West of the 1880's. There was a lack of a stable citizenry, especially in the mining districts. Many people, white and Chinese, were constantly moving from place to place and from job to job.

But at the same time, the $1880^{\prime}$ 's was a period of rapid change and economic disruption. The gold was running out and the railroads were being completed. Manufacturing was becoming more important. ${ }^{1}$ As people moved from the mines and railroads into the cities and factory work, a skilled labor glut developed, and there was high unemployment. Two depressions developed in the $1870 \mathrm{s.}^{2}$ 
With the depletion of the mines and the end of railroad work, more and more chinese began to move into manufacturing work, which had previously been dominated by whites. ${ }^{3}$ Coolidge says that as early as 1862 there were complaints from whites about competition from.Chinese labor in the cigar-making industry. ${ }^{4}$ Daniels and Kitano say that in the 1870's Chinese shoemakers outnumbered whites four to one, and Chinese also dominated the textile industry. ${ }^{5}$ we pointed out in Chapter IV that Chinese were seen as unskilled labor, and the more skilled and dignified factory work had been seen as the province of whites only. ${ }^{6}$ winther describes the result of these circumstances in the Portland of the $1870^{\prime} \mathrm{s}$ :

When the Central Pacific line was completed in 1869 many of the unemployed Chinese drifted north, principally to Portland where they competed with white workers for jobs. Anti-Chinese sentiment arose at once, and this was heightened by the financial panic of 1873. In Portland... demonstrations were made against the Chinese which resulted in many acts of violence. 7

The Racist Nature of Anti-Chinese Hostility

Basically, such agitation was racially motivated, and its rhetoric was racist. Chinese were used as scapegoats for depressed economic conditions, for which they had no more responsibility than the white workers. The racist system of employment in America had, as we have seen, uplifted white workers, and kept the chinese in a lower position. ${ }^{8}$ when white workers saw their positions threatened, they turned on the Chinese. 
White Americans were also at this time still engaged in the establishment of their way of life on the West coast. The presence of the Chinese, who had a vastly different way of life, was seen as threatening. Many whites had left the East to escape from the racial problems involved in the slave question. They wanted an exclusively white society in the West to avoid such difficulties here. ${ }^{9}$

A racist, sterotype of the Chinese evolved, which bore only a tenuous relationship to the facts. Agitators promoted ideas such as:

...the women... are the most degraded prostitutes,

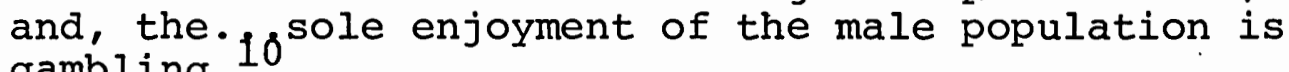
gambling. 10

In 1876, John H. Mitchell, U.S. Senator from Oregon, referred to the Chinese in a speech on the floor of the Senate as:

...this festering sore which, like a plague-spot had fastened itself upon the very vitals of our western civilization and which today threatens to destroy it. II

He accused the Chinese of degrading white labor, corrupting trade, having no interest in American culture or institutions, and debauching and defiling American youth. ${ }^{12}$ The most racist tract we have come across is a pamphlet written in 1902 by Samuel Gompers, the organizer of the AFL. It is filled with statements that would today seem laughable if they were not so filled with hatred; but it gives us some idea of the feelings of the time. Just one example is this statement, about how the Chinese supposedly made opium addicts of white young people: 
They have become what is known in the parlance of the street as "dope heads"--opium fiends in the ordinary language. In some manner, by some wily method they were induced by the Chinese to use the drug. Time was when little girls no older than 12 years were found in Chinese laundries under the influence of opium. What other crimes were committed in those dark and fetid places when these little innocent victims of the Chinaman's wiles were under the influence of the drug are almost too horrid to imagine. 13

\section{"Cheap Chinese Labor"}

We referred in the last chapter to the fact that antiChinese agitators claimed the Chinese were in essence slave laborers, under the despotic control of the Six Companies. We believe that this idea is inaccurate; but it should be emphasized that it was a widely held belief in the 1880's, and contributed greatly to the cause of the anti-Chinese racists. 14

The most important argument of the agitators was not Chinese slave labor, however, but cheap Chinese labor. There is considerable question about whether Chinese labor was actually cheap; and there is a great deal of uncertainty about whether this in any way caused white wages to be depressed. Daniels and Kitano state that when the Chinese entered the shoe industry in the 1870's, wages fell from twenty-five to nine dollars a week. ${ }^{15}$ and a nautical cords factory proprietor testified in 1876 that white males received between $\$ 2.25$ and $\$ 5.00$ a day, white children received $\$ 1.00$ and "Chinamen" ninety cents. 16 But whether such instances were the rule or merely isolated incidents is open to question. 
The opinion of most researchers seems to be that Chinese never remained cheap labor for long in any industry because, as Coolidge puts it, "The Chinese were thoroughly organized into tongs, i.e., trade unions, long before white laborers."17 A Chinese spokesman in 1901 said that the Chinese were less skilled and less productive than white factory workers, and therefore paid less. ${ }^{18}$ Ping Chiu says Chinese labor did not depress white wages:

The presence and availability of a large Chinese labor force had, in a few instances, "prevented" strikes on the part of white workers from being successful. However, the overall effect on wage levels was probably negligible. Low wage rates had been established, in most cases, before the entry of the Chinese.

And Carey McWilliams says of the idea that the Chinese were in some way responsible for the economic depressions of the 1870 's :

Although the argument seemed plausible, there would have been a depression in California in the 1870's if the entire populations had beem made up of lineal descendants of George Washington.

Other Arguments Against the Chinese

Other arguments against the Chinese presence in America can be dismissed more easily. The Chinese were said to be immoral and degraded. We have discussed the reason for prostitution, gambling and drug use in the Chinatowns (see Chapter III). One California newspaper, Argus, pointed out in 1886 that:

The Chinaman has many vices-- smokes opium; plays "tan," buys lottery tickets, and does a great many 
other things that he should not do-- but he is industrious, frugal, temperate, peaceful, and pays his debts and "washes his slate" at the close of the year. His white brother had all his vices and but few of his virtues. 21

The Chinese were also accused of being thieves and criminals; ${ }^{22}$ and inflated figures on the number of Chinese in jail were published by the anti-Chinese elements. But statistics show that the percentage of Chinese in the jail population was much less than their percentage in the general population. 23

There were fears that the Chinese would soon increase in numbers so much that they would dominate the region. But there were at most times almost as many Chinese leaving the country as there were entering, ${ }^{24}$ and in any case the exclusion laws beginning in 1882 put a stop to this supposed threat.

Chinese were said to be unassimilable. Even the oregonian claimed in 1880 that:

He begins as a Chinaman and as a Chinaman he ends. Useful as he is for so many purposes, yet so far as the experience of a quarter of a century enables us to judge, he has not the making of American citizenry about him. 25

And yet it was the whites who would not let the Chinese become citizens, attend American schools, live in American neighborhoods, etc.

It was also said that Chinese sent most of their money out of the country. There were many wild estimates of the millions of dollars in gold that the Chinese had supposedly 
removed from the United States. But others attempted to point out that the Chinese paid for their money in labor, the benefit of which remained in America; and also that they bought many products here. 26 Coolidge is of the opinion that the Chinese sent less money home than most immigrants, and provides a table showing the Chinese paid millions of dollars in taxes into local governments in America. 27

McWilliams concludes that "The arguments...pro and con on the Chinese question were a hodgepodge of irrelevant nonsense and pseudo-anthropological theorizing."28

The end result of all this anti-Chinese propaganda and agitation was that in the 1880's the call went up for removal of the chinese. In town after town, mobs formed under the slogan, "The Chinese must go!"

THE ANTI-CHINESE RIOTS, 1885-1887

In Chapters III and IV we covered much of the background to the anti-Chinese riots of the 1880's. AntiOriental agitation became an important issue in oregon in the 1870's, and was a political issue during LaFayette Grover's successful campaign for governor in 1872 .

The Workingmen's Party

Anti-Chinese organizations began to spring up on the West Coast. In California, some such groups were started as early as the 1850 's, ${ }^{29}$ but in oregon they did not begin to appear until the $1870^{\prime} \mathrm{s}$. The most important of these 
organizations, and the model for the others, was the Workingmen's Party in California, under the leadership of an Irish immigrant, Dennis Kearney. It was organized in 1877.30 It was Kearney who coined the slogan, "The Chinese must go!" The evolving labor movement was at the center of the anti-Chinese agitation. This appears at first paradoxical, for egalitarianism was perhaps the central ethic of the labor movement. And yet the early labor leaders were vehement racists. They favored an egalitarian, classless society; but for whites only. Saxton believes that "...two psychological factors-- frustration and consciousness of nonChineseness-- welded the non-Chinese labor force into a bloc..." ${ }^{31}$

Kearney in fact worked against the Chinese more than he worked for the rights of workers, and this resulted in some disagreement in his Workingmen's Party. His chief rival for the party's leadership, Frank Roney, wrote:

It was essentially an anti-Chinese party as was indicated by the motto, "The Chinese must go." However, I never warmed to that feature of the agitation. I realized that the cry was superficial, but agreed to sail under the flag so emblazoned in order that I might in time have other and real subjects considered by the people, which I deemed to be of far greater importance to their permanent well-being $\underline{1}$ i.e., trade unionism issues $T .32$

Most other well-known socialists and unionists of the time were also blatantly racist. We have already mentioned Gompers. Jack London is another example of this phenomenon, as Daniels and Kitano observe: 
Jack London probably spoke for most of his supposedly. revolutionary brethren when he declared, "I am first of all a white man and only then a socialist." 33

The Utility of Anti-Chinese Racism to Labor Organizers

The fact was that, while most of the vile allegations leveled against the Chinese were totally false, the white workers did have some viable arguments against Chinese workers. We have seen that there did exist some industries where Chinese labor was used to the exclusion of white workers-- such as the salmon-canning and cigar-making businesses. Chinese were also occasionally used as strike breakers. We mentioned in Chapter $\mathrm{V}$ the case of the oregon City woolen mill strike of 1869. Chinese from California were also used to break strikes by the Knights of St. Crispin in North Adams, Massachusetts, Belleville, New Jersey, and Beaver Falls, Pennsylvania, from 1870 to $1872 .^{34}$

Anti-Chinese agitation also served several useful functions for labor organizers. The issue was useful as a rallying point, and as a political issue which could be manipulated by labor. 35 This racist element in labor continued to exist until recent times, and has been an important factor in the development of the labor movement. Herbert Hill observes:

The choice made by labor organizations--their vigorous participation and leadership in the antiOriental agitation and their use of racial distinction to keep categories of workers outside their organizations-- was an important factor in setting a pattern for the establishment of a racial labor caste system which was to develop into a major characteristic of the American labor movement. 36 
The Workingmen's Party obtained considerable power and political influence in California through its stand on the Chinese question. It sent 50 of 149 delegates to the California constitutional convention in 1878, and influenced state elections for years to come. ${ }^{37}$ Ironically, Kearney himself was not a "workingman" at all, but a dray operator and employer of several draymen. 38

The Pattern of Anti-Chinese Hostility

The atmosphere for the 1885-1887 riots was thus set by a pattern of anti-Chinese hostility that had evolved over the previous decades. The pattern began with violence of white miners against Chinese miners in the 1850's. A state investigating commission in California in 1862 documented eighty-eight cases of Chinese miners murdered by whites, and claimed that this was only a "very small proportion" of the total. 39 In 1871 rioters burned down the Los Angeles Chinatown, killing twenty-one Chinese (fifteen by lynching.) 40 Similar riots, on a lesser scale, occurred all along the West Coast in the 1870's-- in Antioch, Truckee, Vallejo, Madeira, and elsewhere. 41 In 1877 , a mob attending a Workingmen's Party rally rioted, and burned down several Chinese washhouses in San Francisco. 42

Politicians jumped on the anti-Chinese bandwagon. Leland stanford, who had loved the Chinese when they built his railroad, was forced to change his stand when he ran for the Senate from California in 1876. Both the Democrats and 
and the Republicans included anti-Chinese planks in their national platforms in 1876 , but the Democrats were more vehement. 43

In Portland, a Chinese was killed by a policeman in 1871, and the Chinese protested stongly. ${ }^{44}$ But by 1873 , it was the whites who were doing the protesting, and the Chinese began to cower in their homes. We wrote in the last chapter of the formation of the Oregon Anti-Coolie Association in that year. In 1879 several anti-Chinese rallies occurred, and an effigy of President Hayes shaking hands with a Chinese was burned. ${ }^{45}$ Around this time the "Chinese problem" also became an important political issue in oregon. 46

Anti-Chinese Riots on the West Coast

But in 1885, three years after the first exclusion act supposedly solved the Chinese problem, the most serious wave of riots occurred. They grew out of the racist atmosphere engendered by the events outlined above, and by the knowledge on the part of the rioters that, public opinion being what it was, they were unlikely to be punished whatever atrocities they committed. As Blauner says:

It is a general law of colonial racial systems that the oppressing group has a license to kill members of the "inferigr" race without serious likelihood of punishment.

The result was a general atmosphere of lawlessness all along the West Coast. 
In September of 1885, twenty-eight Chinese miners were murdered, their homes burned, and all chinese expelled from Rock Springs, Wyoming, by the Knights of Labor, when the Chinese refused to join a strike. No one was arrested. ${ }^{48}$ The same month, at Squaw Valley, Washington, two or three Chinese hop pickers were killed. Four days later, the quarters of Chinese miners at Coal Creek were burned. 49 In November, 1885, the Chinese were expelled from many Washington towns, including Tacoma and Puyallup, and the Chinese were shipped to Portland. ${ }^{50}$ A riot in San Francisco resulted in Chinatown being burned down and thirteen chinese killed. 51

\section{Anti-Chinese Riots in Seattle}

A long, drawn out struggle to expel the Chinese took place in Seattle, beginning in september of 1885. A series of mass meetings and marches took place, aimed at both the Chinese and civil authorities. All seattle newspapers, except the Chronicle, called for the expulsion of the Chinese.

In October, the rallies were replaced by threats and bomb scares, and concern developed among civic officials over their ability to keep order. The white community became highly factionalized. On November 3, Governor Watson Squire issued a proclamation calling for order, and the next day civic officials and some anti-Chinese leaders met with Chinese community leaders, explained the situation, and advised them to leave town. Over 150 Chinese did so. 
On November 7, Governor Squire and 350 soldiers from the Vancouver Barracks arrived to keep order; the reyenue cutter Wolcott entered Seattle harbor with guns exposed, and the home guard was called out. The soldiers did not really help matters, however; in fact, there were incidents of soldiers beating and robbing Chinese.

In December, the state legislature passed several pieces of anti-Chinese legislation. In January, agitation leaders who had been arrested on riot charges were tried and found not guilty.

On February 7, 1886, a mob entered Chinatown and escorted 350 Chinese to the dock to be taken to San Francisco. Fares for passage were raised for only 196 of these, however, and the next daythey departed. But the return of the remaining 150 Chinese to their quarters enraged the mob, and a fight with police developed in which one man was killed. On February 9, on the request of Governor. Squire, President Cleveland sent federal troops to Seattle, and martial law was declared. Most of the remaining Chinese left town within the week. The troops remained until July, but the trouble was over. 52

In 1887, the last of the serious anti-Chinese incidents occurred at the Log Cabin Bar, on the Snake River at the border of Oregon and Idaho. Seven white men killed ten Chinese. Four of the murderers were eventually captured after a search for them was initiated by the Cinese consulate in San Francisco, but none were convicted. 53 
For all of these murders and destruction of property, the Congress provided only $\$ 424,368.49$ in indemnities. 54 Several cities in Washington were faced with wholesale closures of factories after the departure of Chinese laborers. 55 Events in Portland.

Compared to the incidents outlined above, the events in Portland were not nearly as severe; but there was still considerable anti-Chinese agitation here. On February 13, 1886, an "Anti-Chinese Congress" was held, with 173 delegates in attendance, and resolutions were passed demanding that the Chinese leave town within forty days. The resolution opened: Whereas, the Mongolian race in the state of Oregon and the territory of Washington are as a class of people, constant violators of all health and police laws, are immoral, degraded and undesirable in every sense of the word, as well as a constant menace to free institutions, to house and family...56

The congress also resolved to boycott the Oregonian, to which the Oregonian replied: "The Oregonian does not depend for its business upon the vile, vicious, riotous and criminal classes." 57 Two local newspapers, however, supported the anti-Chinese element. The city officials and businessmen were in favor of the Chinese presence in the city; and, viewing the example of seattle above all wished to keep order. The city militia was mobilized. The "Emmett Guard," an Irish unit of the Oregon Militia (Company B, First Regiment, Second Brigade), was disarmed and disbanded when fifteen of its twenty-five members refused to take an oath of: allegiance. 58 
Brunette G. Haskell; an anti-Chinese agitator from San Francisco, arrived in Portland on February 16 and was escorted to his hotel by a torchlight parade. 59

On February 21, a committee of fifteen was appointed by the agitators to notify the chinese to leave. The next night another torchlight procession was held, and in oregon City the Chinese were driven from the woolen mills and sent to Portland, and the factory closed down. Two men were later arrested for this act. 60

On February 26, the oregonian reprinted a letter by Rev. Trumbell Lee, which had previously been printed in another newspaper. Lee said that the Chinese must go because they were unassimilable, unclean and immoral; and Chinese labor worked at the expense of white labor. The oregonian also printed a reply by Chan Han Fan, a Chinese leader, which accused Lee of trying to incite riot. Chan argued that civilized men were kind to strangers; and Americans could not say they were more civilized than the Chinese if they acted violently toward them. 61

On February 28 masked men drove the Chinese from Albina, and on March 4 at 4,30 a.m., fifty masked men drove 125 Chinese from Mt. Tabor to Portland. On March 12, the Chinese homes at Guild's Lake were raided, a building fired, and the Chinese expelled. On the same night, an attempt was made to dynamite a Chinese house in North Portland. 62 
Portland citizens met with Mayor John Gates on March 13, and Gates called a meeting for March 16 to consider how to keep order. The meeting was supposed to have been held in the circuit courtroom of the County Court House, but the anti-Chinese faction arrived early with one thousand supporters, and began a meeting of their own, chaired by sylvester Pennoyer. The Mayor and his supporters met in the county courtroom, and this meeting was also well attended. Mayor Gates appointed a committee of fifteen to keep order. 63 On March 23, an attempt was made to blow up a wash house in Chinatown, and the next day a Chinese house in East Portland burned down. March 24, was the date the agitators had set for the removal of the Chinese from Portland, and two additional militia companies had been organized, but by this time the violence seemed to have spent itself. 64

Scattered indidents occurred for some time thereafter. A dynamiting incident occurred in East Portland in July, and Chinese in a laundry in East Portland were attacked in August. A Chinese camp at Mt. Tabor was dynamited in September. ${ }^{65}$

But Portland had escaped the loss of life, mass expulsion of Chinese, and serious civil disorders that other West Coast cities had experienced. What violence there was had been largely confined to the outlying areas of the city. 
Sylvester Pennoyer, one of the leaders of the agitation, capitalized on the riots and became governor in 1887. His opponents continued to think of him as a somewhat unbalanced rabble-rouser, but Robert Clark says: "Despite his somewhat irregular conduct in office, Pennoyer was one of the outstanding chief executives of the state." 66

But he never lost his anti-Chinese attitudes. He was responsible for the passage of anti-Chinese legislation (to be discussed in the next section). When President cleveland had W. Q. Gresham wire Pennoyer in 1888 concerning possible violence to the Chinese, and suggested that Pennoyer "employ all lawful means for their protection in Oregon," Pennoyer wired back: "I will attend to my business. Let the President attend to his." 67

In summary, there were intense feelings against the Chinese in Portland in the 1880's, and considerable agitation against them. But, as James Robertson put it, "Such conflicts have been less frequent and of a milder nature than in the history of both California and Washington. 68

\section{ANTT-CHTNESE LEGISLATION}

We have talked about American treaties with China and about some of the federal legislation. It remains to review anti-Chinese legislation on the local level, and the impact of such laws on the lives of the Chinese in America. We have mentioned the miner's taxes and prohibitions against owning mining claims in both California and oregon. 
Early Legislation in California

In 1850, the California Supreme Court ruled that chinese could not give testimony or bring suit against whites. Chief Justice Hugh C. Murray based his decision on an 1849 statute that provided that no "black or mulatto person or Indian" could give evidence against a white and ruled that Chinese were legally Indians, because both were racially Mongolian. 69

An 1855 statute in California required ship owners to pay $\$ 450$ for each passenger ineligible for citizenship. (e.g. Chinese). An 1862 law required non-mining Chinese to pay $\$ 2.50$ a month in special taxes. Both of these laws were invalidated by the Burlingame Treaty of 1868.70

In 1863 Chinese were denied the right to attend public schools in California. This law was not declared unconstitutional until 1885. 71 In 1870, a "cubic air ordinance" aimed at the Chinese was passed in San Francisco, requiring five hundred cubic feet of air per person in living quarters. Hill says that "So many Chinese were arrested that the jails were violating the law."72 In 1873 a law was passed against the Chinese practice of carrying baskets at the ends of long poles. In 1876 a "queue ordinance" was passed requiring the cutting of queues of Chinese who entered jail. These ordinances were declared unconstitutional by a U.S. Circuit Court. 73

In 1878 a new California state constitution, written by a convention dominated by members of the Workingmen's 
Party, prohibited Chinese corporations, employment of Chinese by any corporation, and employment of Chinese for public works. These provisions were also declared unconstitutional by a U.S. Circuit Court. 74

In 1873, a referendum in California showed 154,658 voters (95.8\%) against Chinese immigration, 833 for, and 5,884 with no opinion. But the ballots said only "Against Chinese Immigration," and to vote "for" one would have had to cross out the word "Against" and substitute the word "For." 75

\section{Legislation in Oregon}

Oregon modeled many of its anti-Chinese laws on the California legislation. The 1857 Oregon state constitution provided that Chinese who arrived in the state after the adoption of the constitution could not hold real estate or work mining claims. Chinese were also denied suffrage. Some of these provisions were declared void on the adoption of the Burlingame Treaty. 76 In 1862, poll taxes and miners taxes for Chinese were passed. 77

Portland also passed several anti-Chinese ordinances, In 1863 a twenty-five dollar per quarter tax on laundries was passed but ruled unconstitutional two weeks later. ${ }^{78}$ In 1865 two additional ordinances were passed. One prohibited Chinese from using any building for a residence; the other placed a ten dollar per quarter tax on washhouses. ${ }^{79}$ In 1873 Portland passed its own cubic air ordinance, requiring 
five hundred fifty cubic feet per person. ${ }^{80}$ In 1874, an ordinance was passed against loitering on the sidewalks, and was enforced only against the Chinese. ${ }^{81}$ In 1878, the City Council prohibited the hiring of Chinese for work on streets or public works. ${ }^{82} \mathrm{All}$ of these ordinances were eventually voided by the courts.

In 1887, after the Burlingame Treaty had been repudiated, Governor Pennoyer again proposed a bill to make owning mining claims illegal, and the bill passed. ${ }^{83}$

\section{Federal Legislation}

Nationally, the most important anti-Chinese legislation involved the various exclusion acts-- the act of 1882 , the Scott Act of 1888, the Geary Act of 1892, the Gresham Treaty of 1894, and the bill unilaterally renewing the Gresham Treaty in 1904. We reviewed the provision of these acts and treaties, and the reaction of the chinese government to them, in Chapter IV.

Another important piece of national legislation was a 1970 statute that provided that only free white persons were eligible for citizenship, but Chinese immigrants were denied naturalization rights until 1943.

Much of the federal legislation was challenged by the Chinese in the courts, but was upheld. The Geary. Act, rer quiring registration of all Chinese in America, was strongly resisted, but to no avail. It was upheld by the supreme Court in 1893.85 
The boycott of American goods to China in 1904 also aroused interest and activity in America, Various business leaders came out in favor of limited Chinese immigration in order to protect our trade with China. William D. Wheelwright, president of the Portland Chamber of Commerce, wrote a memorial to President Roosevelt favoring Chinese immigration. 86 Newspapers all over the contry, including the oregonian, vehemently opposed this idea. 87

Effect of Exclusion on the Chinese

Harrassment of Chinese entering this country continued in the 1890's and early 1900's. The Nees say that between 1890 and 1900, twenty thousand Chinese were refused admittance for spurious reasons--they lacked American-style marraiges (although they might be married to U.S. residents according to Chinese custom); they were said to have diseases; they refused to offer bribes; or there was no translator available for their dialect. 89 In 1892, the steamer Haytien Republic, with sixty-seven Chinese on board, was seized in Portland, and the passengers held without food. ${ }^{90}$ Portland Chinese in 1905 protested against their treatment by U.S. Immigration Inspector Charles Alisky. 91

\section{Changing Attitudes. Towards the Chinese}

The Chinese still suffered much prejudice during this period. Chinese were expelled from LaGrande in $1893 ;^{92}$ and there was an attempt to expel the Chinese from John Day in 
1905. 93 The labor unions, and especially the AFL, continued their extreme anti-Chinese attitude. But Chinese were beginning to be more accepted as a part of everyday life. A woman who was a young girl at this time observed to oregon Historical Society interviewer Charles DiGregorio that "Everybody's cook was Chinese, and everybody had a cook." 94 she also indicated the reason for this new attitude of acceptance toward the Chinese: The Japanese had replaced the Chinese as the new "Yellow Peril."

Chinese were now regarded as hard workers, straightforward and honest, while it was the Japanese who were immoral, criminal, and dangerous to the white American lifestyle. In 1908 Gompers reprinted an anti-Chinese pamphlet originally published in 1902, and in the introduction stated:

If in the following pages the reader were to scratch out the word Chinese wherever: it appears, and insert Japanese, the pamphlet would-- with perhaps the exception of a few figures-- be a fair portrayal of the conditions now existing...95

\section{THE CHINESE COMMUNITY IN PORTLAND}

Life was obviously hard for the Chinese during this period (1880-1905). But by the turn of the century, the Chinese had been in Portland nearly fifty years. Their community was well-established, and a second generation, American born, was developing. The Portland Chinatown grew in size in the 1890 's, and by 1900 was the second largest 
Chinatown in America, next to San Francisco, It had a population of 7,841 (see Table TT).

Chinatown Lifestyle

We have much more information on the lifestyle and organizations among the Chinese in Portland during this period than we had for earlier times. Harvey Scott wrote in 1890 :

To strangers, there is nothing more attractive than the Chinese quarter... The main fact to notice is their presence, and Portland's tolerance of them. They are not a particularly desirable people. 96

Seid Back, Jr., one of the leaders of the Chinese Community, put together a souvenir pamphlet on Portland's Chinatown for the Lewis and Clark Exposition in 1905.97 This pamphlet provides both a description and a defense of the Chinese way of life. Back wrote:

With an approximate population of two thousand, Chinatown occupies a distance of about a third of a mile along second street, in the very heart of the city... The buildings, which are of brick, average three stories in height, but often have two floors to the normal story. The rooms are exceedingly small. The stairways are very narrow and, like the rooms, void of light and air.98

Back continues with descriptions of various Chinese shops and temples, and information about chinese customs.

Percy Maddux provides much the same description: ...hundreds of Chinese would transact their affairs in a single building, many of the buildings being rented from white people at enormous rates, Others conducted their business on the sidewalks, with their fruit stands, vegetable stalls, meat shops, chicken coops, and other paraphernalia.99 
Of the enormous rents charged, Louise Arden, in an article in the Oregon Journal, wrote that a two-story building with a forty foot frontage rented for eight hundred to one thousand dollars a month. Twenty-by-twelve foot rooms sometimes slept twenty Chinese. 100

Crowded conditions led to bad health conditions, which were blamed on the habits of the Chinese rather than on the white landlords. Ben Maxwell describes conditions in the Salem chinatown (and we can assume that conditions were similar in Portland):

The trickling streams of wash house slime, the decomposing refuse from Chinese kitchens and the stinking remains of the fish and poultry combined to render these places nuisances of a deadly character.101

There were frequently voiced concerns among the white community about disease in the Chinese quarter; when a Chinese leper was found in 1903, the city was nearly in a panic. 102 Mental health was also a problem among the Chinese of this time; and still is a problem for many elderly Chinese today, although the Chinese don't like to talk about it. There appears to be some evidence of a direct relationship between the discrimination experienced by the Chinese and their mental health difficulties. A 1973 study of California mental hospital records by Berk and Hirata disclosed that there was a sharp increase in the diagnosis "paranoia" in the years 1886 to 1896, which was the period immediately following the imposition of the exclusion legislation and the most extreme incidents of anti-Chinese hostility. 103 
Chinese to a large extent retained their traditional life style into the first decade of the twentieth century. Maddux speaks of the consternation caused by the sight of a wealthy Chinese merchant who appeared in Chinatown in 1905 in Western clothes. 104 An account written in 1899, however, says that

A small percentage of the Chinese in Portland have become thoroughly Americanized, having adopted the American style of clothing, and living in private residences in the residence portion of the city... 1995

Chinese holidays were still celebrated in a big way. Many people have written of how the workers in the rural areas would flock to town for the Chinese New Year's celebration. The district and family associations would throw feasts for their members, and Chinese house-servants would pass out gifts to the families of their employers. 106

At the turn of the century, the Chinatown was in the process of changing its location from Southwest Portland around Second Street to Northwest Portland, around Fourth Street near Everett. 106

\section{Chinese Organizations}

The Chinese organizations were all-important to the Chinese during this period. As an older Chinese man told us:

Being an alien group there's got to be some sort of banding together; if for nothing else just the social reasons... Chinese organizations played

a very important part of our life.

The earliest accounts of traditional Chinese organizations (i.e., those having their roots in chinese culture) of 
which we have records are unfortunately not too flattering to the Chinese. The "tongs," protective organizations of laborers which also controlled the vice in Chinatown, were evidently among the first Chinese groups to be organized in Portland.

Evidently the Bow Leong Tong was the first to arrive in Portland, from San Francisco. But in 1889 the Hop Sing Tong and others moved in, and tensions over this invasion of Bow Leong territory immediately ensued. On December 5 the first "tong war" in Portland occurred at Second and Alder, in which a number of Bow Leongs and Hop Sings fought with hatchets and guns. Three men were killed and two wounded. The Hop Sings were the victors in this battle, but the Bow Leongs continued to be the most powerful tong in Portland for some years to come. 108

Two days after this first tong "war" the police made the first of many attempts to crack down on tongs in Portland, by raiding the headquarters of several Chinatown organizations.

Family and district associations were also organized in Portland about this time. Karen Wong says that the largest family association was the Lee; ${ }^{109}$ and Bessie Ying Lee says that around 1900 the Hoy Yin District Association had several thousand members in Portland, 110

The Chinese Consolidated Benevolent Association (CCBA) in Portland, which arbitrated matters between Chinese groups 
and individuals and acts as the spokesman of the Chinese community, also evidently started in the 1890 's, although the exact details of its beginning are lost. ${ }^{111}$ Its headquarters was originally on the second floor of a building at Second and Pine. Bessie Ying Lee says that:

When the Association was first organized, Chinese stores were taken as units; for at that time every Chinese was associated with a store in one way or another. Owners of each store elected a person to act on the Board of Directors...112

This system was changed in 1910, but it demonstrates the degree of influence exercised by merchants in the Chinese community.

The Chinese in Portland did not have their own consulate at this time, and had to refer their problems to the Chinese Consul in Seattle. As early as 1883, former President U. S. Grant wrote to Chinese Ambassador Cheng Tso Ju requesting that the Chinese consider sending a consul to Portland, 113 but it was not until 1906 that one was appointed, and even then the position was an honorary one for many years. It is assumed that other Chinese organizations and particularly the CCBA, helped the Chinese with their immigration problems and other matters in lieu of a consulate.

As in the period discussed in the last chapter, religious organizations seem to be the most numerous type of association among the Chinese, though perhaps not the most popular. Several Chinese temples existed, the most important of which was located at $641 / 2$ Second street (see Figure 4). 114 


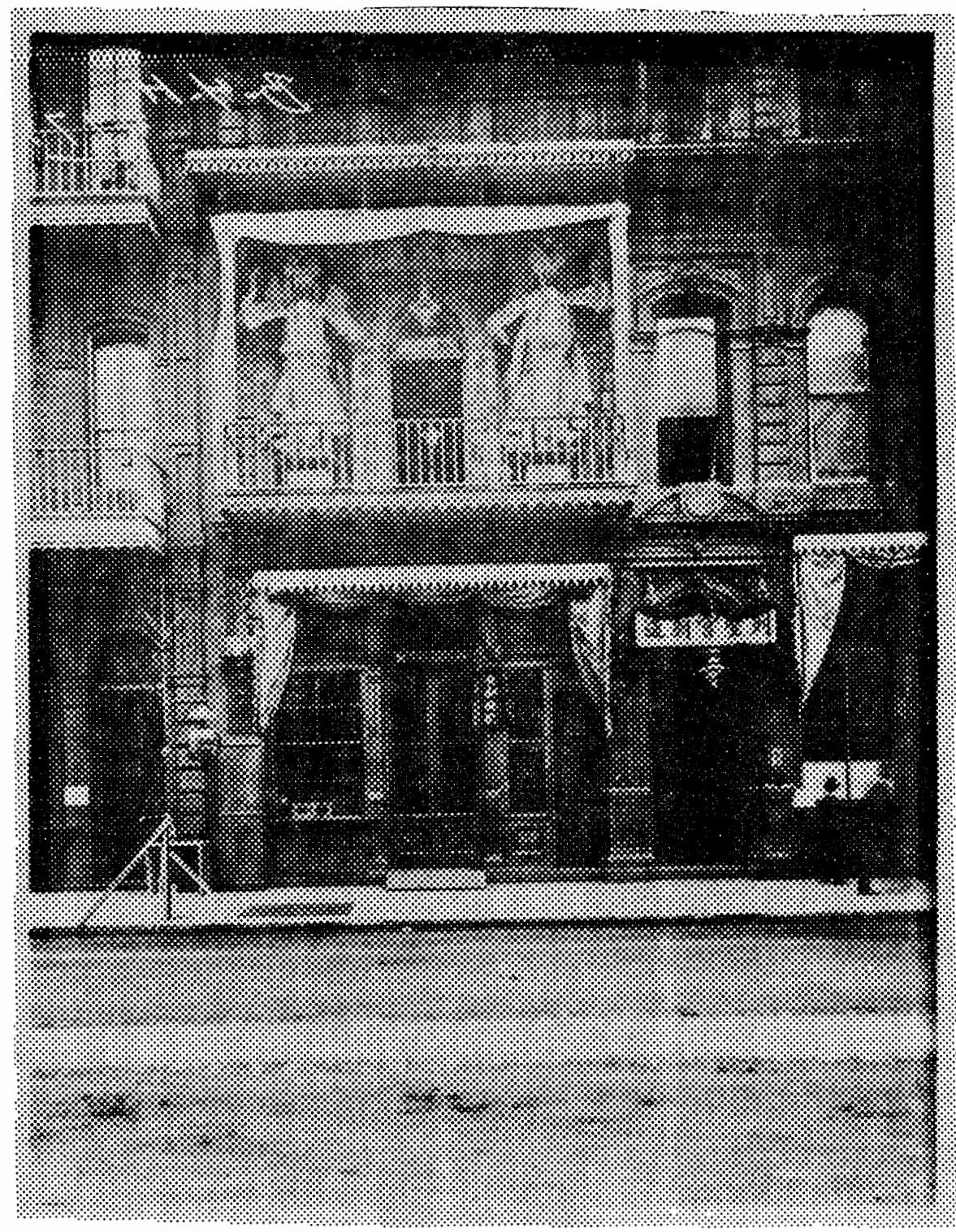

Figure 4. Chinese temple, 64 1/2 S.W. Second Street, c. 1900

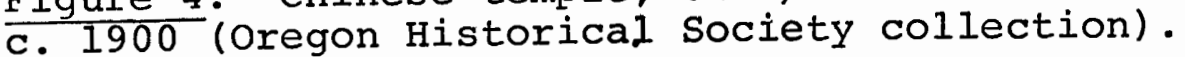




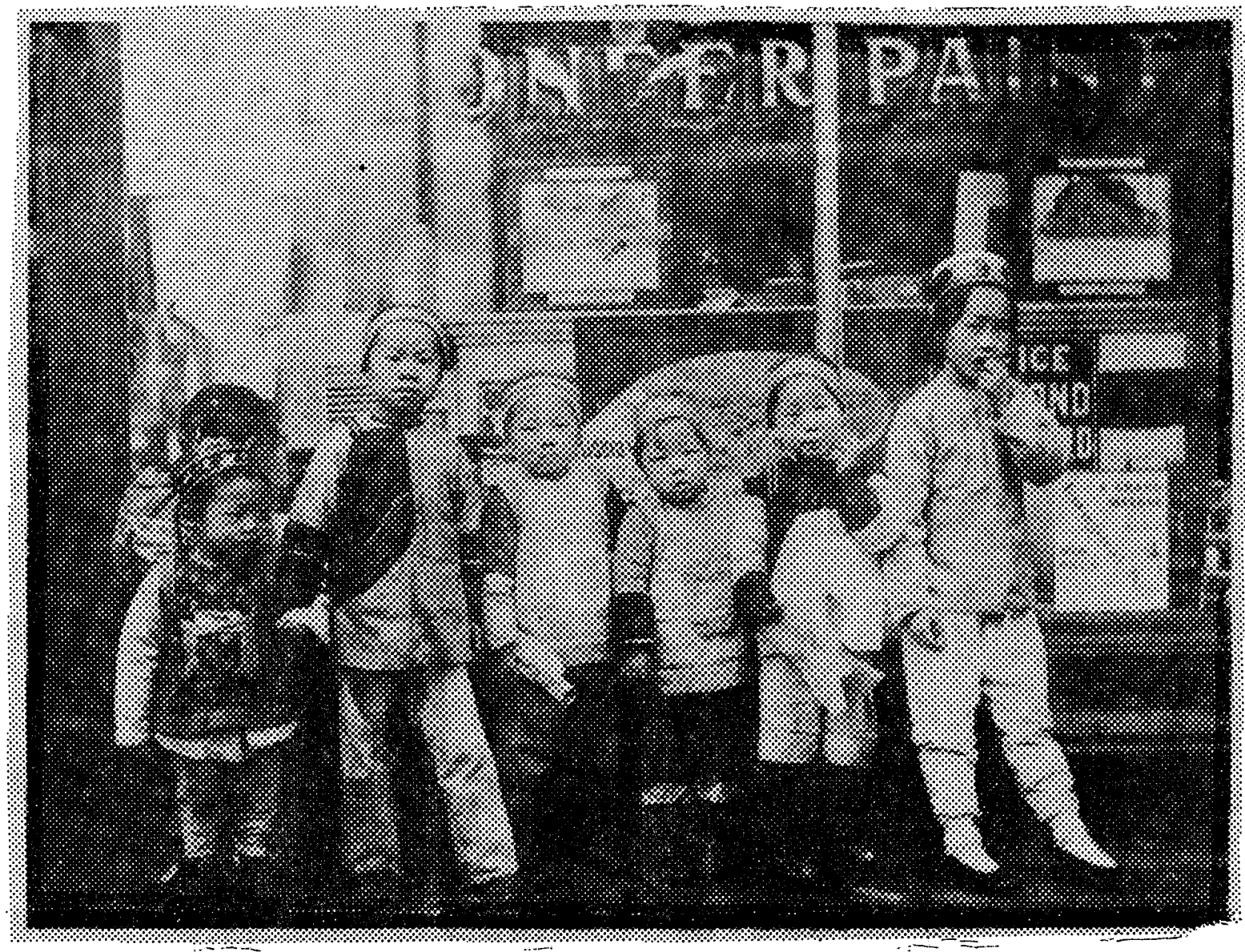

Figure 5. Chinese children on S.W. Second Street, c. 1900 (Oregon Historical society collection). 
Many of the mission schools discussed in the last chapter lasted only a few years, but a few continued operations. The National Editorial Association, in a brochure issued for their 1899 national convention, mentions five such missions: the Methodist Episcopal, Christian, United Brethren, Presbyterian, and Baptist. 115

Two of these churches continue today. We mentioned the Chinese Baptist Church in Chapter V. The other is the Chinese Presbyterian Church, founded by Dr. and Mrs. William S. Holt in 1885, and from 1913 called the Holt Chinese Church. The Holts had been missionaries in Canton and Shanghai. The Portland church was originally located on Southwest Yamhill. By 1889 a night school had an attendance of ninety-seven Chinese. 116

The Chinese did not originally approve of the Christian missions; in 1878 a Chinese who had attended the Baptist mission English classes was killed in a Chinese temple because he was mistakenly thought to be a Christian. 117 There were rumors of a plot to murder Dong Gong, the pastor of the Baptist mission. But this situation soon changed, and by 1899 the Chinese community included about four hundred Christian converts. 118

The missions acted as an Americanizing and acculturating influence on the Chinese, in addition to their religious functions. They taught the Chinese English and provided them with contact with white Americans and their values that would otherwise not have been available. 
One of the wealthiest men in the Chinese community was Seid Back; and his son, Seid Back, Jr., was responsible for organizing two organizations of second generation Chinese in Portland. In June, 1898, the American-born Chinese Brigade was formed with Back as Captain. It had thirty-five members, and used the armory of the Bishop Scott Academy for weekly drills. 119 It was said to be the only Chinese military unit in the United States.

In 1900, Back organized an organization called the American-Born Chinese Association, with sixty-six members. The total number of native born Chinese in Portland at this time was estimated at two hundred. ${ }^{120}$ Back explained the purpose of this organization in a letter to the Oregonian:

It is not in any sense a political body. Our articles of incorporation show that we are banded together for mutual benefitt, mental improvement, social intercourse, etc. 121

The organization also sought to inform its members about American institutions. This group eventually developed into the Oregon chapter of the Chinese-American Citizens Alliance, one of the more prominent groups in the Chinese community today.

\section{SUMMARY}

The life of the Chinese in Portland around the turn of the century was thus difficult, and permeated with reminders of white discrimination. But the community was growing and becoming more stable. Mutual support organizations of ail 
sorts were developing. The Chinese still lived largely in the way they did in China; but a generation of American born Chinese was growing up, and there were indications that family life was becoming more common among at least some Chinese.

The next chapter will explore the history of the Portland Chinese community in the first half of the twentieth century. This period is within the memory of many Chinese living today, and is, except for recent times, the period of the most dynamic change in the chinese community. 
${ }^{1}$ Ping Chiu, Chinese Labor in California, 1850-1880, (Madison, Wisc.: University of Wisconsin, 1963), p. 52.

${ }^{2}$ Victor G. and Brett De Bary Nee, Longtime Californ': A Documentary Study of an American Chinatown, (N.Y.: Pantheon Books, 1973), pp. 43-47.

3 ibid., pp. 43-44; and Charles Henry Carey, History of Oregon, (Chicago-Portland: Pioneer Historical Publishing Co., 1922), Vol. I, p. 838 .

${ }^{4}$ Mary Roberts Coolidge, Chinese Immigration, (N.Y.: Henry Holt and Co., 1909; reprint ed., N.Y.: Arno Press and The New York Times, 1969), p. 357.

${ }^{5}$ Roger Daniels and Harry H. L. Kitano, American Racism: Exploration of the Nature of Prejudice, (Englewood Cliffs, N.J.: PrenticeHall, Inc., 1970), p. 39 .

6 Robert Blauner, Racial Oppression in America, (N.Y.: Harper and Row, Publishers, 1972), p. 63 .

${ }^{7}$ Oscar Osburn Winther, The Great Northwest, (N.Y.: Alfred Knopf, 1950), p. 330 .

8 Blauner, pp. 22-23.

${ }^{9}$ Gunther Barth, Bitter Strength: A History of the Chinese in the United states, 1850-1870, (Cambridge, Mass.: Harvard University Press, 1964), p. 42; and Herbert Hill, "Anti-Oriental Agitation and the Rise of Working-Class Racism," Society, X (Jan./Feb. 1973) p. 43.

10 Barth; p. 153. Quoted from a report of the San Francisco Board of Assistant Alderman, c. 1854 .

${ }^{11}$ John H. Mitchell, "Immigration of Chinese: Speech of Hon. John H. Mitchell of Oregon in the Senate of the United States, May 16, 1876" (Washington: Judd and Detweiler, Printers, 1876) p. 4.

12 ibid. , pp. 4-10.

${ }^{13}$ Samuel Gompers and Herman Gutstadt, Meat vs. Rice: American Manhood Against Asiatic Coolieism: Which Shall Survive?, (San Francisco: American Federation of Labor and the Asiatic Exclusion League, 1908), pp. 19-20. 
14 Barth, p, 131; and Christopher Howard Edson, The Chinese in Eastern Oregon, 1860-1890," (San Francisco: $\mathrm{R}$ and E Research Associates, 1974l, p. 41.

${ }^{15}$ Daniels and Kitano, p. 39'.

${ }^{16}$ Nee, p. 45 .

17. Coolidge, p. 389. See also, Frederick A. Bee, The Other Side of the Chinese Question-- Testimony of California's Leading Citizens, (San Francisco: Woodward and Co., Printers, 1888; reprint ed., San Francisco: R. and E. Research Associates, 1970), p. 70; and Alexander Saxton, The Indispensible Enemy: Labor and the Anti-Chinese Movement in California (Berkeley; University of California Press, 1971), p. 215.

${ }^{18}$ Ho Yow, "Chinese Exclusion, A Benefit or a Harm?", North American Review, CLXXIII (Sept. 1901) p. 318.

19 ${ }^{9}$ Chiu, p. 12 .

${ }^{20}$ Carey McWilliams, "slavery and the Chinese Question," in Cracks in the Melting Pot; Racism and Discrimination in American History, Melvin Steinfield, editor, (Beverly Hills, Cal.: Glencoe Press, 1970; pp. 117-123), p. 121.

$21_{\text {Bee, p. } 4 .}$

22 Edson, p. 43 .

${ }^{23}$ Coolidge, p. 450 .

24 James I. Wong, Aspirations and Frustrations of the Chinese Youth in the San Francisco Bay Area: Aspersions upon the Societal Scheme, (San Francisco: $R$ and $E$ Research Associates, 1977), p. 4 .

25 "The Real Objective," editorial, Oregonian, Nov. 11, 1880, p. 2 c. 1.

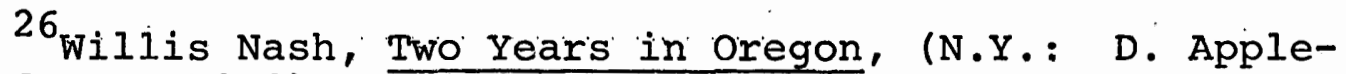
ton and Co., 1882), P. 204. See also "Money Sent out of the Country," Oregonian, Feb. 26, 1886, p. 4 c. 1 .

27 Coolidge, Table 1, "Foreign Miners' License Taxes, 1850-1870," p. 37; and pp. 430-431. See also, Six Chinese Companies, Memorial; An Address to the Senate and House of Representatives of the United States, (San Francisco: Six Chinese Companies, 1887; reprint, ed., San Francisco: $R$ and E Research Associates, 1971), pp. 6-7. 
${ }^{28}$ Carey McWilliams, Brothers Under the Skin, (Boston: Little, Brown and Co., 1943), p. 96,

${ }^{29}$ Chia-lin Chen, "A Gold Dream in the Blue Mountains; A Study of the Chinese Immigrants in the John Day Area, Oregon, 1970-1910," (Masters thesis in History, Portland State University, 1972), p. 28.

30 ibid., p. 29.

${ }^{31}$ Saxton, p. 258 .

32 ibid., p. 122 .

${ }^{33}$ Daniels and Kitano, $p, 48$.

34 Barth, pp. 197-198.

${ }^{35}$ Hill, p. 46; and Saxton, pp. 263-264.

${ }^{36}$ Hill, p. 44. See also Daniels and Kitano, p. 45; and Saxton, p. 269.

${ }^{37}$ Isabella Black, "American Labour and Chinese Immigration." Past and Present, (July 1963) p. 64.

38 ibid.; and Saxton, p. 117 .

${ }^{39}$ Nee, p. 38 .

40 Chen, p. 29; and H. Brett Melendy, The Oriental Americans, (N.Y.: Twayne Publishers, Inc., 1972), pp. 32-39.

${ }^{41}$ Chen, pp. 29-30; and Melendy, pp. 32-39.

42 Melendy, pp. 32-39.

${ }^{43}$ Shih-Shan Henry Tsai, "Reaction to Exclusion: Ch'ing Attitudes Toward Overseas Chinese in the United States, 18481906," (Ph.D. dissertation in History, University of Oregon, 1970), pp. 144-146.

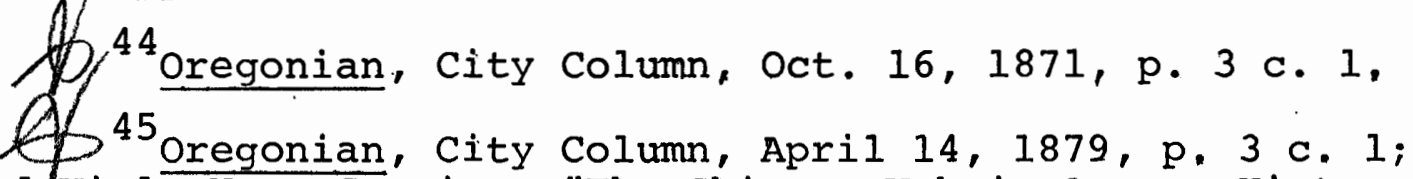
and Viola Noon Currier, "The Chinese Web in Oregon History," (Masters thesis, University of Oregon, 1928), p. 47.

${ }^{46}$ Chen, p. 29.

47 Blauner, p. 39.

${ }^{48}$ Chen, pp. 31-32, and Tsai, pp. 218-220. 
49. Dorothy O, Johansen, Empire of the Columbia, (N.Y.: Harper and Row, Publishers, 1967), p. 348.

${ }^{50}$ Sianey Warren, Farthest Frontier, (N.Y.: MacMillan and Co., 1949), pp. 149-140; and Chen, p. 32.

$51_{\text {Tsai, }}$, 241 .

52 Jules Alexander Karlin, "The Anti-Chinese Outbreaks in Seattle, 1885-1886," Pacific Northwest Quarterly, XXXIX (April 1948) pp. 103-130.

53Edson, p. 51; and Tsai, pp. 249-251.

${ }^{54}$ Tsai, p. 232 and pp. 256-257.

${ }^{55}$ Currier, p. 63 .

56 "They Met. The Anti-Chinese 'Congress' in Session Yesterday," Oregonian, Feb., 14, 1886, p. 5 c. 3-4.

57 "The Manifesto of Riot," Vregonian, Feb. 14, 1886, p. 4 c. 1 .

58 "Was there Danger of Riot?," Oregonian, Feb. 17, 1886,

$\gamma_{\mathrm{p}} \cdot 3 \mathrm{c} \cdot 4$

59 ibia.

${ }^{60}$ Leslie M. Scott, History of the Oregon Country, (Cambridge, Mass.: Riverside Press, 1924), Vol. ITI, p. 225; and "The Oregon City Outrage," Oregonian, Feb. 23, 1886, p. 2 c. 1 .

W p. 3 c. 4 ; and "A Chinaman's Letter," Oregonian, Feb. 26, 1886 , p. 5 c. 5 .

62 "Another Chinese Outrage," Oregonian, March 5, 1886 , p. 3 c. 3; and Scott, Vol. III, p. 225 .

63 "The Proceedings of Yesterday," Oregonian, March 17, 1886, p. 2 c. 1 ; and scott, Vol. III, p. 225 .

${ }^{64}$ scott, Vo. III, p. 225.

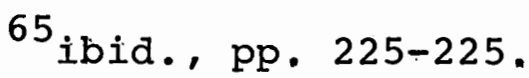

${ }^{66}$ Robert Carlton Clark, History of the Willamette Valley, Oregon, (Portland-Chicago: S.J. Clarke Publishing Co., 1927), Vol I, p. 689. 
${ }^{67}$ Originals of both telegrams in the Oregon Historical Society, Portland; MSS 1521, "Ethnology-- misc.., Chinese."

${ }^{68}$ James R. Robertson, "The Social Evolution of Oregon," oregon Historical Quarterly, III (March, 1902), p. 28.

${ }^{69}$ Wong, p. 2 .

70 Tsai, pp. 147-149.

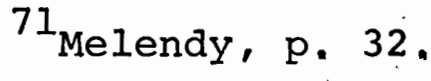

72 Hill, p. 48; and Tsai, pp. 147-149.

73 Melendy, pp. 32-35; and Tsai, pp. 147-149.

74 Daniels and Kitano, pp. 133-134; and Tsai, pp. 147149 .

$75_{\text {Melendy, p. } 38 .}$

76 Edson, pp. 44-48; and currịer, p. 25.

77Edson, pp. 44-45; and Currier, p. 26.

${ }^{78}$ oregonian, City Column, June 13, 1863, p. 3 c. 1; and "Opinion of Judge Shattuck," July 1, 1863, p. 2, c. 3-4.

79 oregonian, City Column, sept. 16, 1865, p. 3. c. 1.

${ }^{80}$ Oregonian, City Column, June 28,1873, p. 3 c. 1.

${ }^{81}$ Oregonian, City Column, Feb. 6, 1874, p. 3 c. 2.

${ }^{82}$ Currier, p. 46.

83 "Munger's Anti-Chinese Bill," Jan. 22, 1887, p. 2

c. 1-2; and Currier, p. 64 .

84 Melendy, p. 30 .

${ }^{85}$ Tsai, p. 282.

86 "Sends Letter to President," Oregonian, July 13, 1905, p. 9 c. 3 .

87 Oregon Historical Society Scrapbook, SB 61, p. 198. ${ }^{88}$ Nee, p. 60 .

${ }^{89}$ Coolidge, p. 311. 
$90_{\text {Tsai, p. } 284 .}$

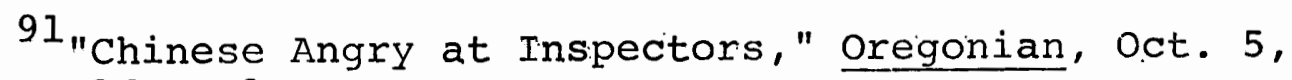
1905, p. 16 c. 1 .

9.2 An Illustrated History of Union and Wallowa Counties, (Western Historical Publishing Co., 1902), p. 183.

${ }^{93}$ Chen, pp. 111-112.

94 Ellen MacVeigh, interview conducted by Charles DiGregorio, in Portland, February 20, 1976. Tape cassette. oregon Historical Society.

${ }^{95}$ Gompers, p. 4.

96 Harvey w. Scott, editor, History of Portland, (Syracuse, N.Y.: D. Mason and Co., Publishers, 1890), pp. 437438 .

${ }^{97}$ R. W. Steel and seid Back, Jr., Chinese Souvenir of the Lewis and Clark Centennial Exposition, (Portland: R. W. Steel and Seid Back, Jr., 1905).

98 ibid.

${ }^{99}$ Percy Maddux, City on the Willamette; The story of Portland, Oregon, (Portłand: Binfords and Mort, Publishers, 1952), p. 84 .

100 "This Was Portland," by Louise Arden, Oregon Journal, oct. 28,1956, p. A9, c. 1-4.

${ }^{101_{B e n}}$ Maxwel1, "The Chinese in Salem," Marion County History, VII (Dec. 1961) p. 13.

102 "'Leper's Grave' Has New Marker," by Ann Reynolds Leo, Oregon Journal, May 29, 1955 p. IlM; and Howard M. Corning, Dictionary of Oregon History, (Portland: Binfords and Mort, Publishers, 1956), p. 53.

10.3 Cited by Alex C. N. Leung, "Mental Illness Among Chinese in the United States: Myth or Reality?", (Masters thesis in Psychology, Portland State University, 1976), p. 18.

104 Maddux, pp. 84-85.

105 National Editorial Association, Portland, Oregon, 1899, (Portland: National Editorial Association, 1899), p. 2.

${ }^{106}$ Nash, p. 207; Chen, pp. 105-106; and Fred Lockley, History of the Columbia River Valley, (Chicago: S. J. Clarke Publishing Co., 1928), Vol. I, p. 545. 
107 Bessie Ying Lee, "Perpetuation of Primary Group Patterns Among the Chinese in Portland, Oregon," (Masters thesis in Sociology, University of Oregon, 1938), p. 39.

${ }^{108}$ Maddux, pp. 92-94; Currier, p. 65; and Karen $C$. Wong, Chinese History in the Pacific Northwest, (privately printed, /Seattle?/, 1972), pp, 90-91.

${ }^{109}$ Karen Wong, P. 91.

110 Bessie Ying Lee, p. 71.

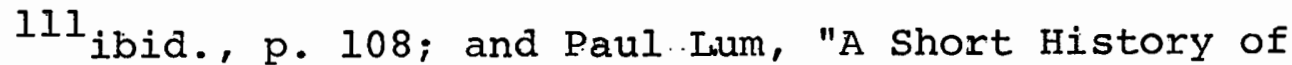
the Portland CCBA," Oregon Chinese News, No. 46, (March/Apri] 1975), pp. 6-7.

112 Bessie Ying Lee, p. 108.

113 Letter from Cheng Tso Ju to U.S. Grant, April 17, 1883, (Oregon Historical Society manuscript; MSS 1521,

"Ethology-- misc.., Chinese").

114 National Editorial Association, p. 2.

$115_{\text {ibid., p. } 3 .}$

${ }^{116}$ Helen Ruth Montague, "Chinese Missions in Portland, Oregon," (unpublished manuscript,. Oregon Historical Society, MSS 1147; and Paul Cheng, "Pastor's Report in the Congregation Meeting" (unpublished manuscript, Chinese Presbyterian Church, Portland, Dec. 4, 1977).

117 "Sanguinary Affair," Oregonian, Oct. 4, 1878, p. 3 c. 2; and "Death of Chin Su Ying," Oregonian, Oct. 7, 1878, p. 3 c. 5 .

118 National Editorial Association, p. 3.

119 ibid., p. 1 and p. 3.

120 "Getting Ready to Vote," Oregonian, April 29, 1900, p. 24, c. 1 .

121 "Not a Political Society," letter from Seid Back, Jr., Oregonian, April.30, 1900, p. 5 c. 5. 
CHAPTER VIT

THE AMERTCANTZATION OF THE CHINESE, 1905-1943

In Chapter VI, we reviewed records of eleven Chinese organizations existing in Portland at the turn of the century-- the CCBA, the Hoy Yin District Accociation, the Lee Family Association, two tongs, two organizations of native born Chinese, and four missions. From 1905 to 1943, many more organizations came into existence, but paradoxically the Chinese population in Portland dropped from nearly 8,000 to only 1,500 persons.

As with our previous chapters, we will begin our account of this period with some historical background information on the Chinese experience in America at this time.

\section{CONTINUED RESTRTCTION ON TMMIGRATION}

Exclusion of Chinese laborers from the United States, and laws against naturalization of Chinese continued until 1943. Even then, an extremely low quota of 104 per year was set for Chinese immigration. Additional restrictive legislation was passed during this period.

Anti-Chinese racism and derogatory stereotyping of the Chinese was still very prevalent in America, and American public opinion supported exclusion. Helen Givens cites 
a 1928 survey that showed 22.4\% of the public in favor of exclusion of Chinese, $13.8 \%$ in favor of excluding Koreans, and $2.5 \%$ who would exclude Japanese. 1 Frank Jordon, the California Secretary of State, proposed the import of Chinese labor in 1919, but received vigorous opposition. ${ }^{2}$ In. 1907, the Oregonian, quoted a New York newspaper which was in favor of Chinese immigration:

"The patriotic pride of China is still only in the process of being awakened," says the $/ \overline{\mathrm{N}} . \mathrm{Y} .7$ Journal of Commerce7, "China will, in due time, make it necessary for us to readjust our treaty relations with her on a basis conformable to her new place among the nations." 3

But the Oregonian went on to state that the people of the East did not understand the "race problem" in the West; Chinese immigration was out of the question.

The Chinese problem continued to be an election issue in Oregon. In 1922 Walter M. Pierce, a Democrat who was alleged to have ties to the $\mathrm{Ku} \mathrm{Klux} \mathrm{Klan}$ and who favored exclusion of Asians, was elected governor of oregon by the largest vote ever given a gubernatorial candidate, ${ }^{4}$

Anti-Chinese Legislation

In 1913, California passed an "Alien Land Bill" which prohibited Asians from owning land, 5 Although aimed at the Japanese, this bill also applied to the Chinese, In 1923, after years of controversy over the question, Oregon passed a similar law. 6 
In 1917, the U.S. Congress established a "barred zone," including most of Asia, from which all immigration would be excluded. In 1921, a law was passed which prevented Chinese from becoming U.S.' citizens by marriage. A 1924 immigration act further restricted immigration. Combined with the 1921 legislation, it effectively barred Chinese women from the United States, It also redefined the "student" category to allow admission only of those Chinese working for post-graduate degrees. 7 Daniels and Kitano say that because of this legislation:

If one were forced to choose a year in which racism and xenophobia seemed most triumphant, 1924 would be a good year to pick. ${ }^{8}$

In 1930, this legislation was amended in regard to the admission of wives of Chinese, but only those married prior to 1924 were allowed in the country. ${ }^{9}$

\section{Application of the Exclusion Laws}

Many injustices accurred as a result of the way the exclusion laws were applied. A 1923 letter from a Chinese businessman in Vancouver, British Columbia, complained of restrictions in Canada on immigration and business:

Our people are badly discriminated against, almost unbearably so... The conditions are improved but not much because we don"t have a stable and even recognized government to support us.10

Chinese were still often detained at entry points for months at a time, even if they were legally entitled to enter the United States. Chen provided letters recording many 
such instances. The detention center at Port Townsend, Washington, was well known to the Chinese, and was called the "wooden house." One man was incarcerated for two and a half months on his return from a visit to China. The son of another Chinese immigrant was held for two months while immigration officials demanded a one thousand dollar deposit to insure that he was a legal immigrant. ${ }^{11}$

In 1933, immigration officials in Portland delayed the entry of representatives of the Canton Merchants League, who were bringing exhibits of Chinese goods to the Century of Progress Exhibition In Chicago. Chinese community leaders and the Portland Chamber of Commerce delayed a banquet for the visitors and "tried to achieve their release, but they were told that the merchants needed either a certification from the Chinese government that they would not overstay their visa, or bonds of five hundred dollars each. Eventually the steamship company provided the bonds. ${ }^{12}$

In 1916, a Chinese who had Iived in Portland since age seven, and was engaged to marry a local girl, was deported by immigration officials despite protests from both the white and the Chinese communities in Portland. ${ }^{13}$ As late as 1964, Chinese still experienced troubles with immigration officials. A cook who had lived in Portland for several years was deported when it was claimed he fabricated a marriage to his sister to gain entry to the United States, 14 
Such difficulties were not universal; our interviews and those of Chia-lin Chen disclose many cases of Chinese who say they had no problems entering the United States.

\section{Illegal Immigration}

The strictness of the immigration laws, however, did create a situation in which many Chinese entered the United Stated illegally.

The "paper son" scheme was the most prevalent form of illegal immigration. Sons of American born Chinese who were born in China were legally entitled to U.S. citizenship and entry into America. Thus, many American born Chinese who visited China would falsely report the birth of a child upon their reentry to the United States. This created a "slot" for an illegal immigrant which could be sold. 15

Many Chinese were also smuggled into America by way of British Columiba. ${ }^{16}$ others bribed ship captains in Hong Kong to be made a part of the crew, and then would jump ship upon arrival in America.

The Portland Chinatown was subjected to frequent raids by immigration officials, and many newspaper articles were devoted to the exposure of real or supposed smuggling conspiracies. In 1910, the tongs were accused of running an "underground railroad" of illegal Chinese laborers. Immigration officials established a policy of holding suspected illegal aliens without bail and incommunicado, on the assumption that otherwise they would be coached on how to answer 
the questions of the officials. 17 In 1931, another tactic was tried. Immigration officials told Chinatown residents that the legality of their residence would not be investigated if they voluntarily turned in new arrivals. This scheme was at least partially successful. 18

In 1957 the Refugee Escape Act included provisions for an amnesty for "paper sons" and eight thousand Chinese confessed to being illegal aliens between 1959 and 1969 in order to legitimize their status. 19

Illegal immigration existed from the very beginnings of Chinese immigration and has continued until recent times; but the Chinese we interviewed were understandably reluctant to talk about it. It was another situation imposed on the Chinese by the discriminatory laws of the United States.

The Repeal of Chinese Exclusion

With the advent of the Second World War, China became an ally of the United States against the Japanese. Japan took advantage of the continued existence of Chinese exclusion in its anti-American propaganda.

Pressure for repeal of exclusion developed in the United States. A Citizens" Committee to Repeal Chinese Exclusion was formed in May of 1943. It was opposed by a variety of historically racist groups-- the AFL, the VFW, the American Legion, and the Native Sons of the Golden West. All of the old anti_Chinese arguments were revived. But the repeal forces prevailed, and on December 13, 1943, the 
repeal bill was signed into law. Chinese were for the first time permitted to become naturalized American citizens, and an immigration quota of 105 per year was instituted. 20

Additional legislation, both national and local, followed. (In 1946, Article XV of the Oregon constitution, which prohibited Chinese from holding real estate or mining claims, was repealed. PI $^{1}$ This provision had, however, been a dead letter for many years.

The Displaced Persons Act of 1948 granted permanent residency status to 3,465 Chinese stranded'in the United States following the success of the Commint revolution in China. This was followed by the Refugee Act of 1953 which allowed 2,777 Chinese refugees to enter the U.S., together with two thousand Chinese from Taiwan. The Presidential Directive of May 25, 1962, allowed refugees in Hong Kong to enter America as "parollees," and 15,111 persons took advantage of these provisions. 22

But restrictive legislation continued to be enacted. The McCarron-Walters Act of 1952 confirmed the quota for Chinese immigration at 105, defined anyone with over $50 \%$ Chinese ancestry as Chinese, and reserved $50 \%$ of the quota for professionals. This Act also provided for detention of enemy aliens or subversives in case of national emergency. ${ }^{23}$ In the 1960's Asian immigration was finally treated the same as European immigration. On October 3, 1965; President Johnson signed a bill repealing the national origins 
quota system of immigration. Each nation outside the Western Hemisphere was allowed twenty thousand immigrants per year, The new system was based on the country of birth, rather than on ancestry or race. The number of immigrants from east and southeast Asian countries has since increased over five times. 24

This legislation was passed after years of lobbying by two Chinese civil rights organizations- The Chinese-American Citizens Alliance and the National Chinese Welfare Council.

\section{EMPLOYMENT OPPORTUNITIES FOR CHINESE}

From 1905 until the Second World War, Chinese continued to be subjected to a great deal of discrimination in employment. They were restricted to the same sort of menial, unskilled labor that they had engaged in in the nineteenth century •

Rose Hum Lee provides information on the occupations of Chinese in 1940 and 1950. The major occupations of Chinese in 1940 were service workers (30.48); operatives (22.68); proprietors; managers and officials (20.6\%); and clerical and sales workers $(11.48) .^{25}$ Thus, in 1940,538 of the Chinese workers were engaged in line-level factory or service work. It is significant that one-fifth of the Chinese were at this time "proprietors, managers and officials," for this indicates a distinct improvement over the number of merchants reported in 1880. But most Chinese were still working in more or less menial positions. 
Rortland's Chinese population had aropped from 7,841 in 1900 to 1,416 by 1930, and economic conditions in Chinatown were poor, especially during the depression. An article by Ta-kuei in the magazine of one of Portland's Chinese youth groups, Sing Shar, stated that too many Chinese engaged in bad occupations-- gambling, etc. Businessmen found it impossible to make money from whites. The article cited the Japanese as an example of successful independent entrepeneurs. 26

Continuation of Traditional Employment Patterns

often the traditionatly Chinese areas of employment-restaurants, laundries, etc-were the only ones in which the Chinese could find jobs. Migrant farming and salmon canning continued to be major occupations for Chinese. 27 And Melendy says that:

Chinese restaurants scattered through the cities have provided economic success and security for Chinese of the second and third generation. They have also furnished a financial base for younger Chinese to move into other professions and occur pations. 28

We found the latter observation to be particularly applicable to the Portland Chinese community. Both our interviews and those of Chia-lin Chen found many Chinese who are successful professionals today, but whose first job was in a Chinese restaurant or store.

Employment Discrimination

Barriers continued to exist that made it difficult for the Chinese to move out of their traditional employment areas. 
Chen's and our interviews indicate the prevalence of job discrimination against Chinese in the first half of the twentieth century.

One of Chen's interviewees related the story of his cousin, a stanford graduate with a degree in aeronautical engineering who attempted to get a job with Pan American Airlines. His application was never answered. His uncle, however, was influential in Taiwan, and made a complaint to the Chinese ambassador in Washington, to the effect that the man should be hired by China National Airlines, which was being operated by Pan American. The ambassador wrote the company a letter, and the man got the job. 29

Another of Chen's interviewees was unemployed after graduating from high school, because whites would not hire Chinese, and the Chinese would not hire him because he was from a small and uninfluential family. He eventually found work through the tongs, a traditional refuge for those chinese rejected by both the whites and their own community. 30 Thus, Chinese businesses provided most of the employment for Chinese, even those who were highly trained. It was difficult to get a job in white society.

\section{Labor Unions}

The white labor unions also continued their discrimination against all non-whites. In 1905 California labor organizations joined together to form an Asiatic Exclusion League. 31 The AFL, still under Samuel Gompers, refused 
requests for help from a Mexican and Japanese migrant workers union in 1903. ${ }^{32}$ At its 1913 convention in seattle, the AFL passed a resolution favoring exclusion of Asians. 33

The Sailors. Union consistently protested any hiring of Chinese by shipping lines. The Laundry Wagon Drivers' Union organized a boycott of Chinese laundries in 1909.34 The 1910 Socialist Party Congress in Chicago passed a resolution favoring Asian exclusion, despite serious opposition. ${ }^{35}$

In the 1930's the newly-formed Congress of Industrial Organizations (Cro) showed more tolerance of non-white workers, and several Chinese labor unions, both independent and affiliated with the CIO, sprang up in San Francisco. There was a surge of radicalism among the Chinese community during this time, and many of these developing labor organizations were of an avowedly socialist nature. ${ }^{36}$

There is a myth that Chinese workers had no desire in organizing themselves, but this is only partially true. Chinese were less militant and more compliant than white workers, but they wre certainly not completely docile. From the beginning of the Chinese presence in America there were trade guilds which protected Chinese workers in various industries, such as the laundries, restaurants, cigar factories and shoe factories. These were not strictly labor unions, for Chinese proprietors and managers also joined, and frequently led, such trade guilds. 37 
Chinese workers in Portland, however, were neyer yery well organized. There was a labor organization of Chinese cannery workers, which struck in Astoria in 1205 for withheld pay. 38 In the $1940^{\prime} s$, a union attempted to organize Chinese restaurant workers in Portland, but met.with little success due to opposition from both the owners and the workers. 39 The president of the Portland CCBA told us that while some individual Chinese are members of unions, there are no Chinese unions in Portland, because Chinese are not interested in demonstrating and are happy in their work.

Opening Up of Employment Opportunities for Chinese

The advent of World War II, which created a huge shortage of labor at home, created the first real opportunity for Chinese to enter the labor market. The Nees state that:

It was not until the Second World War that the rapid expansion of the American economy and a new prestige. which accrued to the American Chinese from America's alliance with Nationalist China brought the first major entrance of the American-born generation into white and blue collar occupations. 40

One of the people we interviewed also commented on this phenomenon. He received a job in 1943 with the civil Service Commission just three weeks after graduating from college. He says his ease in finding a job cannot be entirely attributed to the war, but he "..had an edge. In one way you can say I was fortunate."

Today, many Chinese hold white collar and professional jobs; but, as we shall see in Chapter VII, they are still 
under-represented in top managerial posittons. While conditions for Chinese have improved immensely in the last thirty or forty years, a subtle form of employment discrimination continues to exist.

THE PORTLAND CHINESE COMMUNTTY

The Lifestyle in Chinatown

Descriptions of the Portiand Chinatown during the period from 1905 to 1943 indicate that it changed very little from its appearance around the turn of the century. Bessie Ying Lee says:

The buildings... are mainly two or three stories of solid brick. They were built by the white people and leased on long terms to a few Chinese merchants, Many parts of these buildings have been modified to meet the needs of the chinese, The second and third floors are occupied by stores and club houses.' In the windows of the residential places many flower pots are seen. At the front of each store and club the name is inscribed in gold or red Chinese characters on a black board. In the windows there is a display of Chinese foods and other goods imported from China. The new quarter of the chinatown is located in the midst of the Japanese community. 41

Living conditions were not good for the people in Chinatown. One man we spoke to referred to "Those old depressing days, those tough old days." Another of our interviewees who lived in Chinatown during this period described it as a series of tenements above storefronts, with very crowded living conditions; but he said it was also colorful and homey. Another former resident of Chinatown said that 
in the tenements, large rooms were partitioned into tiny apartments. He described the room where he lived:

Cold water, one faucet coming out of the wall, one toilet in the corner somewhere... And of course the electric socket hanging from the ceiling.

The family would go over to a neighbor's house to bathe every Saturday night; the neighbor had a bath tub in the corner of his living room, set off by a screen. But this interviewee also spoke of the advantages of Chinatown life: "It was a much more sociable life, a more colorful life... It was kind of a tough life, but it taught you a lot of things."

As in previous times, Chinatown in this period was a center of illegal activities, One chinese woman interviewed in 1929 by the Oregonian said:

I admit there are many chinese who make their living in lotteries... but do you suppose they want to be lawbreakers or do not have the ability to do other work? No, decidely no. Lotteries are the outcome of the economic struggle of existence. These people can find nothing to do, because institutions and firms do not employ Chinese...42

Retention of Culture, Assimilation, and Integration

The Chinese retained many of their traditional customs, holidays, etc. in the Portländ Chinatown of this period, And yet they also became increasingly more acculturated to American life, and more integrated into the white community.

Bessie Ying Lee spoke in 1938 of intense pressure within the community to conform to traditional chinese norms and values: 
Anyone wishing to avoid disapprobation for his actions in the Portland Chinese community leaves. the city; Some have resorted to this method of escape, 43

Traditional Chinese holidays, notably the Lunar New Year's celebration, were always observed in Chinatown,

But Lee also observed that:

Many American-born Chinese divorce themselves from everything that is Chinese... When they become truly Americanized they find that the Americans do not want them. 44

The development of this new American born generation was a matter of continual concern to the older chinese, A newspaper article in 1921 commented on the concerns of these Chinese that their children had picked up bad habits from American culture. 45

$\underline{\text { Housing }}$

Many. Chinese families were beginning to move out of Chinatown to Southeast Portland and especially to the area around Ladd's Addition. We talked to one man who said that his family was one of the first to move into this area, in 1924 .

Bessie Ying Lee made a survey in 1938 of the location of the Chinese in Portland, the results of which are displayed in Figure 6. Lee says that 408 of the Chinese population consisted of bachelor men, most of whom lived in Chinatown. Only 39\% of the 176 families lived in Chinatown; $45 \%$ Iived east of the Willamette River; and 198 on the west side. Nineteen percent of these families owned homes in 


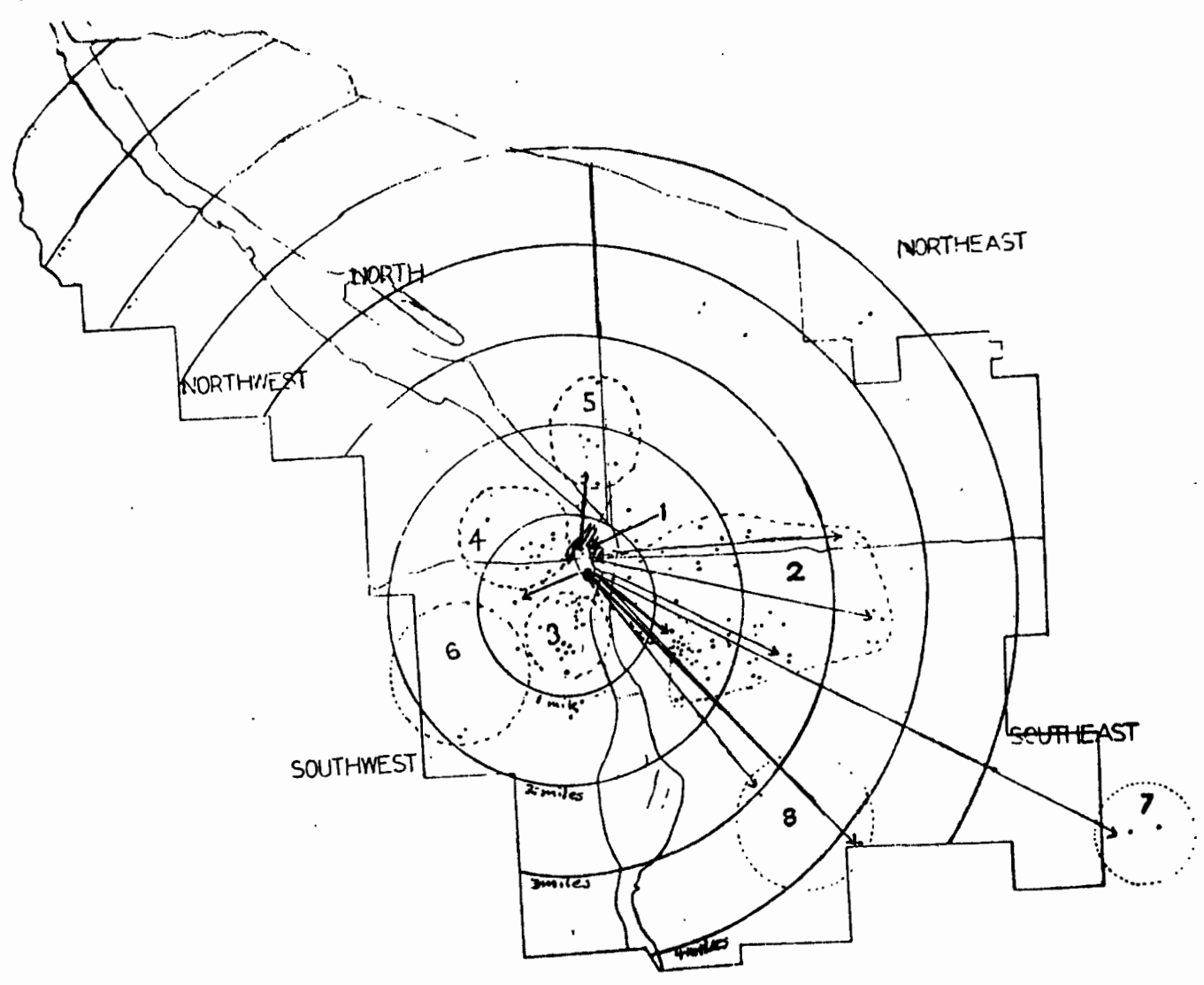

Figure 6. Distribution of the Chinese population in Portland, Oregon, 1938 (from Bessie Ying Lee, "Perpetuation of Primary Group Patterns among the Chinese in Portland, Oregon," p, 43),

Key:

- Dots within the broken line circles represent the number of Chinese families living in these sections of the city.

1 Center of the Chinese community; north end is the New Chinatown, where 43 Chinese families live; south end is the old Chinatown, with 26 Chinese families.

2 American middle-class residential districts.

3 Working class residential districts and Jewish neighborhood,

4 Working class residential districts.

5 Working class and black neighborhoods.

6 and 8 Upper class residential districts,

7 Truck garden district.

(III) Japanese community. 
middle-class neighborhoods (defined as areas where homes were worth more than $\$ 5,000) ; 6 \%$ lived in working class areas (homes worth less thain $\$ 5,000$ ); and $2 \%$ lived in exclusive neighborhoods (homes worth $\$ 10,000$ or more). The remaining $73 \%$ of Chinese families rented homes or apartments, mostly in working class areas or in Chinatown. 46

There are two notable points to be made from these statistics. The first is that it is surprising that any large number of Chinese lived outside of Chinatown, As Lee observes: "The middle-class American whites tend to tolerate the idea of having Chinese living among them..."47 To our knowledge, this situation was unique among large Chinese communities in America at this time; most Chinese in the United States lived in strictly segregated conditions.

The second point, which in part accounts for the integration of Chinese and whites in Portland, is that most Chinese lived in families. This was also an aspect of the Portland Chinese community that was unusual for the time. We saw in Chapter III that the male-female ratio in Portland by 1930 was much more favorable than that for the Chinese in the United States as a whole $(2,3: 1$ for Portland; $4: 1$ for all Chinese in America ${ }^{48}$ ). This probably indicates two things; First, that the Portland Chinese may have had more money, or a greater percentage of merchants, than most Chinese communities; thus enabling men to bring their families over from China or find wives in other cities. Second, there was 
evidently less discrimination by whites in Portland, setting a better climate for family life, and attracting more respectable women from other areas.

\section{Family Structure}

Most Chinese families at this time were very traditional. Chinese was spoken in the home, they ate Chinese food exclusively, respect was demanded from children, etc. One of the Chinese men we interviewed observed that in those days "We knew very little about what our parents were thinking or doing."

Women still held a definitely inferior and protected position in the Chinese community. One of the women we spoke to mentioned constant chaperoning and parental supervision of her activities. Arranged marriages, restriction of women to the home, and similar customs were still observed, but by the $1930^{\prime}$ s were becoming less prevalent.

The old families continued to disapprove of the American born families. Many tried to arrange marriages for their sons in China, rather than with Portland girls, Despite the male-female ratio, Lee found that $30 \%$ of the American born women over 25 were single, 50

Ancestor worship was still practiced by most of the immigrant chinese, but was rejected by their children. 51

The traditional chinese patterns of the extended family were not very strictly observed in the Portland community. Housing and work patterns in America, as well as the 
fact that many immigrants came alone, leaving the family in China, contributed to this situation. Lee observed that only twenty-four of the 176 families she surveyed had three or more generations living in the same household. Most families were small, and similar to most American families. But mutual support among relatives, respect for the elderly, and similar Chinese traditions were still strictly observed. 52 The main problem in Chinese families at this time was the severe generation gap that existed between the Chinese immigrant parents and their American born children. Lee observed that:

It is not surprising that some of those boys and girls should jump to the conclusion that because they have more knowledge of the English language they are more intelligent than their parents. Besides, having a tremendous advantage within the family council, they at times look down upon their parents with scornful superiority. 53

\section{Education}

The Chinese were allowed to attend public schools in Portland, but these schools were segregated. There were certain schools in Portland that were largely or almost entirely Asian.

Atkinson was a nearly all-Asian elementary school located in Chinatown, and even Chinese who did not live in Chinatown often attended this school. None of the teachers knew Chinese. 54 High schools with large Chinese enrollment included Benson, Washington, and Lincoln. 
Several of the Chinese we spoke with were also sent to China to be educated. Almost all of the Chinese we interviewed who had been brought up in Portland attended one of several Chinese language schools. We will discuss these schools later in this chapter.

White Attitudes Towards Chinese

We have observed indications that discrimination against Chinese in Portland was less severe than elsewhere. But in the 1920's and 30's, derogatory stereotypes of Chinese were still widespread in America, and the Portland Chinese were still subjected to many overt forms of discrimination.

Rose Hum Lee cites a 1933 West Coast study of the social distance of white Americans from twenty-three racial and national groups. The Chinese ranked eighteenth. A similar study in the Midwest in 1935 ranked Chinese eighteenth on a list of twenty-one. 55

A Portland Chinese wrote in 1921:

In order to make a living here, we have to endure all year around the drudgery and all kinds of hardship. We are in a state of seeking shelter under another person's fence, at the threat of being driven away at any moment. We have to swallow all the insults hurled at us. Why? All because we are people of a weak nation...

We are as round-headed and square-toed as the Americans are. Why then are they so aristocratic and we so enslaved?

Our interviews and Chen's interviews both elicited numerous incidents of discrimination experienced by the Chinese in these days. Chinese were not allowed in many 
theaters, barberships, and restaurants. We have mentioned job discrimination against even educated Chinese. Although homes were open to Chinese in Southeast Portland, there were many neighborhoods where deed restrictions prohibited the entry of non-whites.

In matters of importance, such as immigration, housing, or employment, Chinese often strugged for equal opportunities. But in more trivial areas of discrimination, such as name-calling or being refused service in restaurants, many of the Chinese we talked to took a very fatalistic and accepting attitude, thinking of it as inconvenient, but not really all that important. One of our interviewees said that he himself was taught not to mix with people of a different race or social class. He said he never received any help from white society, and never asked for any: "I was always on my own...I like it on my own."

CHINESE ORGANIZATIONS IN PORTLAND, 1905-1943

During this period, many different kinds of organizations developed. Some of the old traditional groups, such as the family and district associations, lost membership and became less influential, but most continued to exist. Many new organizations, modeled on American forms, were created, and represent the increasing Americanization of the Chinese community. This was also the period of "tong wars," and Portland, like other West Coast cities, did not escape from the rivalries of these protective organizations. 
Tongs and Tong Wars in Portland

Despite their reputation for inscrutable secretiveness, the tongs were the only Chinese organizations most Americans ever heard about during this time. Numerous sensational newspaper stories were written. Tong wars, while they did occur, were blown out of proportion. Any violence of one Chinese towards another was immediately heralded by lurid headlines telling of a new tong massacre. The newspapers also tended to call any Chinese organization a "tong," whether it was or not.

While we cannot ignore tong violence or the illegal activities in which the tongs engaged, we wish to emphasize the protective and mutual support functions discharged by the tongs.

It is often difficult to trace the history of the tongs, because many of the tongs had more than one name; and because newspapers and other writings would often transliterate the same Chinese name with widely divergent spellings from one article to the next.

We mentioned in Chapter VI that tongs began to move into Portland, by way of San Francisco, in the late 1880's and 1890's. Percy Maddux cites five early tongs: the Hip Sing, Hop Sing, Suey Sing, Bow Leong, and Hung Sing. 57 We do not have any further record of a "Hung sing" tong, but the others became the major tongs in the Portland area and continue to exist today. In 1914 the Bow Leong Tong merged 
with the Bing Kung, and was then known as the Bing KungBow Leong Tong. We have also found reference to the Bow on Tong and on Yick Tong. The Bow on Tong was evidently a minor tong in Portland, though it was important in other cities. The "On Yick" Tong may not have been a tong at all, but another type of organization (e.g., district association). We have few references to it.

We have few records of how many members these tongs had. Today, few of them have over a hundred members in Portland, but in the old days they were large organizations engaged in a variety of activities. Also, although we were able to interview a couple of people who are currently tong members, we were unable to interview anyone who was a member in the halcyon days of the tongs. (Chen does provide a summary of one such interview.)

The purposes and functions of the tongs were multiple. Barth says that:

Behind the facade of social clubs and benevolent associations, the secret societies linked together revolutionary groups, fraternities bent on righting alleged or real injustices suffered by its members, and gangs of criminals which controlled gambling, prostitution, and opium smuggling. 58

Our interviewees emphasized the social and benevolent functions of the tongs. Tong members could meet at their headquarters for social activities, get their mail, and find jobs through the tong. The tongs provided wanted, though illegal, forms of recreation to its members in the form of gambling, women, and drugs. 
But the most important function of the tongs was protective. The bachelor chinese laborers, far from their families and villages, and with few resources, had both a psychological and a practical need for some group which would stand up for them against injustices. The CCBA, being dominated by the merchants and labor contractors, was seen by many laborers as inadequate for such purposes. The district and family associations were only useful if one came from a large or influential family or district, which had many members in the area. One of the people we talked to put it: "The larger the group, the greater the protection; and the larger the group, the more power you had." Chen cites one of the people he interviewed, a long time member of the suey Sing Tong: "In the old days, the tong would protect its members-- no matter whether they were right or wrong, but now, the tong will make an investigation first, then try to settle the dispute through peaceful and reasonable ways." 59

Tongs provided legal aid for members who were jailed, and pensions for those who were wounded in fights or for families of those killed. They attempted to right injustices, or at least obtain retribution. 60

When the long time president of the Bing Kung-Bow Leong Tong, Bing Kee, died in 1933, the oregonian ran a sympathetic article titled "Chinese Mourn Departure of Friend and Benefactor." He was portrayed as "the 'godfather' of 
the aged, infirm and indigent. Not alone the members of his tong. " 61

The Oregonian also covered some colorful legal functions of the tongs, such as several national conventions by various tongs held in Portland, or the openings of new buildings, accompanied by lion dances and firecrackers in the streets of Chinatown. It is interesting that when such events were covered, the tongs were referred to not as "tongs" but as "benevolent associations" or, in the case of the Bing Kungs, "Chinese masons."

But, at least until the 1940's, the Portland tongs were also engaged in many kinds of illegal activities. Another of Chen's interviewees tells of his activities in prostitution, narcotics, and gambling as a Hop Sing operative. 62 In 1920, the Oregonian carried an expose of drug peddling in Chinatown. 63 There were infrequently other reports of drug busts and prostitution. But the major concern in Portland seems to have been the gambling activities of the tongs.

One of Chen's interviewees says that at one time there were about eighty Chinese gambling houses in Portland. 64 And the Suey Sing member referred to earlier said that there were over two thousand Chinese in Portland who made their living from gambling. ${ }^{65}$ (This figure is obviously exagerrated, because in the 1920's and 30's there were less than two thousand Chinese in all in Portland.) 
From the early 1900's until the 1940's, every few years would see a concerted police attempt to wipe out gambling in Chinatown, but their success was never more than temporary. All sorts of tactics were devised. In 1910, the police were not concerned about the Chinese gambling, but about whites gambling in the Chinese houses. They attempted to reach an agreement with the tongs to restrict gambling only to chinese, but this failed. ${ }^{66}$ In 1919 , city officials passed ordinances prohibiting barred doors and secret passageways, also in an attempt to prevent gambling. But this ordinance was struck down by the courts, which said the ordinance "would divide the people of Portland into two classes"-- well-to-do whites who could have heavy doors with big bolts; and Chinese, who could not. ${ }^{68}$ In 1922 , the police, under a tough new district attorney, began a practice of smashing all gambling equipment they found. In 1924 the Municipal Court Judge announced he would impose maximum sentences on Chinese who were caught gambling, most of whom had previously gotten off with light fines. But the judge ended up throwing out cases from the ensuing arrests because the police had failed to obtain search warrants prior to their raids. ${ }^{69}$ When the Chinese were consistently able to successfully appeal their cases to higher courts, the City Attorney began to charge the Chinese on numerous small charges, each with a fine of less than twenty dollars, so that the cases could not be appealed. 70 
Despite all of these ingenious schemes, gambling in Chinatown continued well into the 1940's.

"Tong wars" also occurred in Portland, due to jurisdictional disputes between the tongs. Often these wars were a result of actions that had taken place in California or elsewhere, and the Portland tongs would be obliged to join the war on the orders of their headquarters in San Francisco. In Portland, these wars occurred from 1912 through 1922, and at least twenty men were killed. In other cities, the wars continued to occur well into the 1930's, and resulted in much more loss of life. The dates of individual wars, along with other events in the history of the Portland Chinese community, are provided in Appendix B, "Chronology of the Portland Chinese Community."

The newspapers continuously overplayed the seriousness of the tong wars. An article by a perceptive reporter in 1913 commented: "Tong wars are frequent or infrequent according to the degree in which the police reporters are impressionable." 71

The Peace Society

The police made many attempts to stop tong wars, and had about as much success as they had had with gambling. In 1914, however, six Chinese associations combined efforts in arbitrating a tong war, with the result that a Chinese Peace Society was formed, with Lee Mee Gun as president. This group was generally involved in negotiating the end of tong 
wars. It called together all relevent tong officials (sometimes bringing in national officers from San Francisco), city officials, and Chinese community leaders.

At times it met with failure. In 1917, during the worst of the tong wars in Portland, Lee Mee Gun reșigned in frustration after the failure of two Peace Society-arranged truces.

Subsequent presidents, however, were instrumental in bringing about an early. end to tong wars in Portland. Moe Chog Wai, president of the Society from 1926 until the 1950's, became one of the most respected and influential leaders in the Chinese community.

The Peace Society was finally disbanded in the early 1960 's. 72 Today, the tongs in Portland are no more than social clubs where older men can get together to play cards and discuss the old days.

The Portland Chinese Consulate and Other Chinese Government organizations

The Chinese in Portland were still very interested in affairs in China. It should be remembered that the immigrants were not allowed to become American citizens; they therefore retained their Chinese citizenship.

In 1906, May Back Hin, a wealthy Portland Chinese merchant, was made honorary Chinese Consul for Oregon, Idaho, Washington, and Montana. ${ }^{73}$. This gave him a mandate to work for the interests of the Chinese citizens in Portland. In 
1908, he was reappointed. In 1933 May Back Hin was made the official consul in Portland. ${ }^{74}$

During World War II, the Portland Consul, Silwig P. C. $\mathrm{Au}$, implemented a plan to help whites tell the difference between the Chinese, who were America's allies; and the Japanese. Certificates and identity tags were issued by Au to all Chinese residents of Portland. 75

The Consulate was closed in 1950, and jurisdiction was passed to the Seattle Consulate. 76

Another organization that had connections with the Chinese government was the Portland branch of the Kuomintang, Nationalist China's ruling political party. The KMT had an office in Portland from 1914 until the 1950's, and in the 50 's its office was on the third floor of the Portland CCBA building. The KMT was active in organizing the support of Portland Chinese, and in organizing efforts against both the Japanese and the Communists. 77

Chinese during this period were always active in following Chinese internal affairs. We spoke in Chapter IV about the support Sun Yat-sen received on his visit to America in 1910. Newspaper articles indicate that the Chinese in Portland also supported Sun's revolution, and later opposed the government of Yuan Shi-kai. 78

In 1931 the CCBA helped develop an American Chinese Aeronautics Association. This group raised money to train Portland Chinese men to be pilots in China, and to buy planes 
for China's fight against the Japanese. About thirty pilots were eventually trained and sent to China. In 1937, a China Society was formed to support the Chinese efforts against Japan. 79

In the 1950's, there was concern that the Chinese in Portland who had families in China would be blackmailed by the Communist government, and some Chinese said they had received letters attempting to extort money from them. ${ }^{80}$

Thus, the Chinese community in Portland has continuously demonstrated concern for Chinese affairs, and organizations expressing such concern have developed.

The Chinese Consolidated Benevolent Association

The CCBA was, and continues to be, the most important of the Chinese organizations in Portland, for it coordinates the activities of all the other groups, and sets the goals and priorities for the community as a whole.

From 1905 to 1943, the CCBA continued to perform mutual support and protective functions, as defined in preceding chapters; but the activities developed to fulfill these functions were different than they had been previously. It continued its coordinating functions in the community, and developed many types of services for Chinese.

In 1910, the CCBA obtained a four-story building on Northwest Davis, which it continues to use today. Until the late 1960's, the top floor of the building was used to house young bachelors and students. 
In 1915, the CCBA attempted to raise funds for a medical clinic, but we are not sure if such a clinic was ever established. 81

During the depression, the CCBA provided some relief to poor and unemployed Chinese in Portland. Bessie Ying Lee says that in 1937 forty-six persons were on the CCBA's relief list, and received five pounds of rice every sunday. ${ }^{82}$ Ivan Light says that Chinese organizations throughout the country provided such relief, and provides statistics showing that the percentage of Chinese on government relief roles in 1933 was less than half that for the white population. 83 The CCBA also supplied fares for the return of indigents to China.

The CCBA continued such traditional activities as shipping the bones of the dead back to China. In 1928, the Chinese section of a cemetary in Portland, which had been maintained by the CCBA, was cleared out; and 615 bodies were sent back to China. ${ }^{84}$ In 1948, the CCBA arranged to send bones of 260 Chinese back, but the man entrusted with making the arrangements absconded with the money, and the bones languished on a dock in Hong Kong for several years. ${ }^{85}$ This was the last shipment of bones from Portland to China. In addition to such service programs, the CCBA also organized many social activities for the Chinese community. New Year's celebrations, celebrations of the Chinese national 
day, movies, and picnics were all frequently provided through the CCBA.

The organization of the CCBA changed considerably over the years. We mentioned that in the 1890 's, representation was given to each Chinese store. In 1910, the organization was incorporated in the state of oregon, and a new constitution was written. In addition to representation by stores, every Chinese organization was also given representation on the executive committee. 86

During the 1930's, many stores closed due to the depression and to the shrinking Chinese population in Portland. In 1932 a new system was instituted, in which members of the CCBA's general committee were elected by ballot at a mass meeting of the Chinese community. 87

In recent years (to be covered in the next chapter), this system has again been changed to allow for both at large members and representation of all Chinese organizations on the CCBA's executive committee.

The Chinese Language School

One of the most important activities of the CCBA is the Chinese Language School, located in the CCBA building. Parents can send their American born children to this school to learn the Chinese language and customs. Many people in the Chinese community consider this program to be very important in their efforts to retain and pass on Chinese culture to their children. Nearly all of the people we have 
interviewed who had been brought up in Portland attended the language school as children, and most have sent their own children to the school. The present president of the CCBA commented to us, on the role of the language school, "The Chinese as a whole have a great desire to preserve and perpetuate their culture and their language." Bessie Ying Lee says:

At first the function of the Chinese Language School was to prevent the rapid acculturation of the American-born Chinese youths.... and also to act as an interceding force to reconcile the children who were becoming Americanized in the public schools...88

The Chinese Language School was created in 1908. Eight thousand dollars was raised in one month to initiate the school, and May Back Hin was the first chairman of the school board. It opened with an enrollment of 102 students. In the 1930's, it reached an enrollment of over 160, but attendance declined after World War II, and the school was closed in 1955. In 1959, however, it. was reopened by CCBA president Leland Chin, and continues to the present day with an enrollment of over one hundred students. 89

In the 1920's and 30's, the school operated five days a week from 5:00 to 8:00, and on Saturdays from 9:00 to 11:00. Children often resented having to attend Chinese school after all day in regular school; as one of our interviewees said, "It was quite a grind." But it also afforded the children an opportunity to socialize with their Chinese peers. 
Most of the people we talked with are today glad that they attended the school, and proud that they have retained something of their language and culture.

Family and District Associations

From 1905 to 1943 , the old traditional Chinese organizations such as the family and district associations continued to operate, but lost some membership. Groups organized around more American structures were becoming increasingly influential.

The purpose of the family and district association was to identify people in the community to whom one could always turn for help. During this time period, these organizations helped people find jobs, or housing, or other needed services. They continued to exercise social control functions, as Bessie Ying Lee observed:

...these surname clan organizations often attempt to supervise their members rather closely. They volunteer to mediate minor private affairs without waiting for an individual request as is customary in China.90

They also continued in their protective functions. For instance, in 1934 the Gee How Oak Tan Society, which is the Chin family association, offered a reward for the capture of a murderer of one of its members. 91

Like the CCBA, these associations also provided social activities-- banquets, movies, a society lounge for meeting and talking, etc. In recent years, these social functions 
have become practically the only area of activity of these societies.

Bessie Ying Lee says that family associations were originally formed for the benefit of single men. As of the time of her writing, in 1938, the development of families in the Chinatown had resulted in the associations decreasing in membership and importance. 92

An Oregonian article in 1922 lists eleven family associations: Chin, Wong, Lee, Eng, Lowie-Fong-Fong, Seid, Leong, Lum, Lum Yee, Tim Yee and the Four Brothers fan association including four different surnames). 93 By 1938 . Lee lists only five family associations. 94 . Today there are three family associations-- Lee, Wong, and Chin.

The largest, and for most of this time the only, district association was the Hoy Yin District Association. Lee says that around the turn of the century it had several thousand members, but that by 1938 it had only about one hundred members who were active. ${ }^{95}$ This society continues to exist today. In 1928 a new district association, the Ning young Society, was formed. 96 This society is also mentioned by Lee in 1938, but has disappeared today.

\section{Civil Rights Organizations}

We have mentioned that American-style organizations began to be developed during this period. Considering the history of the Chinese in America, it is natural that the first such organizations to develop worked for civil rights for Chinese and better relations with the white community. 
One of the current stereotypes of the Chinese is that they are a "model minority"-- they don't try to gain opportunities by rioting or demonstrating, but by educating their children and working within the traditional American institutions. This is in fact the attitude of many leaders in the Portland Chinese community. But on the other hand, when clearly defined institutional barriers to advancement have existed, the Chinese have always organized to fight such barriers .

The organization that has been most important in working for the rights of the Chinese is the Chinese-American Citizens Alliance ( $C A C A$ ), a national organization with a chapter in Portland. This group has over the years been instrumental in working against the unjust immigration laws, through lobbying, petitioning, etc. It worked for the repeal of exclusion in 1943 and for the repeal of the national origins quota system in 1965. Today it continues to act as a lobbying group on behalf of Chinese, as an anti-defamation watchdog, and as a coordinator of moderate Chinese civil rights activities.

But the CACA is not only a civil rights organization. It is also an important social organization of the American born Chinese. In Portland, the social functions of the group have been more important than its political functions.

We have seen that an American Born Chinese Association was founded in 1900 by Seid Back, Jr. A similar group, 
called the Native Sons of the Golden State, was formed in 1904 in San Francisco. Its purposes were to protect the citizenship rights of the American born Chinese, and to provide an alternative to the traditional Chinatown organizations. 97 (The "Native Sons of the Golden State" must not be confused with the "Native Sons of the Golden West." The latter group was an anti-Chinese, white supremist or- . ganization existing in California during the same period.)

In 1915, the American Born Chinese Association combined with the Native Sons of the Golden State to form CACA. In 1921 the Portland chapter received its charter. It at that time had a membership of one hundred fifty, and its president was Lee Hing. 98

The Portland chapter, as we have said, was primarily a social club of American born Chinese. They got together to play cards, had banquets, etc. ${ }^{99}$ The civil rights functions were primarily the responsibility of the national organization.

But there were Chinese in Portland who actively worked for civil rights. In 1922, Chinese leaders in Portland protested against the stereotyping of Chinese in movies. One man said:

Chinese try to live right and do right...but in the films we are always represented as trying to steal white girls or as drug smugglers.100

In 1926 W. I. Sun, a Portland Chinese leader, testified before the U.S. House Immigration Committee, protesting 
the ban on the immigration of wives of Chinese. Unfortunately, this effort brought no results, and the Oregonian made light of the importance of the issue with an article called "Chinese Urge Uncle Sam to Give Cupid Fair Show." The article attempted to prove that the male-female ratio was as bad in China as it was in America, because of ancestor worship and the desire of Chinese for male heirs. ${ }^{101}$

In the late 1940's some Chinese in Portland went to court to gain the right to live in white neighborhoods, but this struggle will be covered more fully in chapter VIII.

The Chinese Women's Club

Another American-style Chinese organization was the Chinese Women's Club, organized in 1931 to raise relief funds for the Red Cross in China, and still in existence today. 102 Bessie Ying Lee describes the club as a social, recreational, and charitable group of "emancipated Chinese women."103 The fact that an organization of Chinese women existed at all is an indication that mores and values were changing in the Chinese community; women were no longer strictly tied down to their role as homemaker.

\section{Student and Youth Groups}

During this time there were many Chinese students, both residents and foreign, studying at oregon colleges. The United States had used its share of the indemnity from the Boxer Rebellion to provide scholarships for Chinese 
students, and the immigration laws for students had been relaxed somewhat.

The major organization for Chinese students in Oregon was a national group called the Chinese Students Alliance of America. In 1916 and 1929 the Western Section of this group held its annual conventions in Portland, at Reed College. ${ }^{104}$ This organization still exists, and there are Chinese student groups at Portland State University and at the University of Portland.

In the 1930's, there was a proliferation of Chinese youth groups in Portland, none of which lasted very long. Such groups included a Boys' Activities Club, organized in 1936 by young working bachelors; a Chinese Girls' Club, organized in 1925 for older girls; and the Chinese Girls' Reserves, a social club for high school girls. These groups held dances, organized sports and music activities, and raised funds for charity. There was some controversy among the older, conservative elements of the community about the morality of holding dances. 105

Probably the most significant of these youth groups was the Sing Shar Club, organized by Chung Sing Chow in 1930 "For the purpose of keeping young chinese boys off the streets." This group held discussions on art, literature, and social issues; and published a magazine, the Sing Shar Monthly, in which issues concerning the Chinese community were discussed. 106 
Cultural Organizations

At least two groups organized around Chinese cultural activities also came into being in the 1930's. A woman we talked to told us about a group she had belonged to which practiced kung foo and held lion dances. It was formed in the 1930's and had about fifty members. In 1940 the Yat Sing Music Club, which still exists, was formed. It puts on a Chinese opera annually, and gives performances of Chinese music all over Portland. It has also done charitable work; in 1940 it raised money for the renovation of the CCBA hall. ${ }^{107}$

\section{Chinese Churches}

Another indicator of the increasing Americanization - of the Chinese community is the increasing influence of the Chinese churches. By the 1930's and 40's, most Chinese in Portland were Christian, and almost all the shrines and joss houses that had proliferated in Chinatown were gone. On the other hand, the fact that the churches were Chinese, and the services generally given in both Chinese and English, is an indicator of the continuing sense of identity of the Chinese in Portland.

We have seen that the Chinese churches started as missions, not independent churches. This was still the fact during the period covered by this chapter. The Chinese Baptist Church had white pastors throughout this period, as did several of the smaller missions. The Holt Presbyterian Church and the M. E. Mission, however, had Chinese pastors. 
We have seen that there was a proliferation of Chinese home missions in Portland around the turn of the century. Few of these churches lasted past 1910. Presumedly, a combination of factors accounted for this fact. By 1910, the Chinese population in Portland was on the decline. Interest in the white community in "Christianizing" the Chinese was dropping off. The primary benefit of the missions-- that of teaching English to the Chinese-- was becoming less necessary as most Chinese by this time had lived in America for many years.

A 1909 article in the Oregonian mentions two missions-the Church of the United Brethren and the Christian (Cambellite) Church-- which had been abandoned. ${ }^{108}$ The last record we have of the Methodist Episcopal mission is in 1910.109 And we find no mention of the Portland Chinese Mission after its twenty-fifth anniversary in 1916:110 The remaining Chinese churches, both of which continue today, are the Baptist and Presbyterian.

In 1909, there was some outright hostility on the part of whites toward the Chinese missions. The Oregonian ran an exposé which spoke of "horrible developments in connection with these schools in New York," based on the belief that the Chinese were using the mission schools to seduce the young white teachers. The article speaks of "...the insidious danger that lurks in this association between white girls and Chinamen," and says: 
Who can doubt that it is the sex principle instead of religious zeal that binds these misguided young women to this literal body of death-- the Chinese mission schools of a great city-- until beaten off by the police? 111

An article the next day reviewed the situation of the missions in Portland, and concluded that twenty years of effort had proven futile to Christianize the Chinese; "Oriental peoples cannot be 'converted' to Christianity."112

Chinese churches continued to exist, however, and the Presbyterian and Baptist churches prospered. Around 1916 the Chinese Baptist Church moved from its old location at Fifth and Alder into the "new" Chinatown in Northwest Portland, at Sixth and Couch. 113 In the 1920's, it ran a sunday school, and in 1934 established a Chinese scout troop. It also ran a kindergarten for Chinese children. In 1944, the Chinese Baptist Church was made independent of the home mission board, and was incorporated in 1945, and in the same year bought a lot for a new building at S.E. Ladd. In 1949 the new building was completed, and the Chinese Baptist Church is still located there.

The Holt Chinese Presbyterian Church also operated in Chinatown during this period. It was located first at Fourth and Burnside, on the top floor of a place called the Men's Resort. It later moved to an old building near second and Alder, then to a storefront on Third between Couch and Davis. For many years it shared facilities with a white Presbyterian church at Twenty-eighth and Stevens, but in 1976 it obtained 
its own building at $7604 \mathrm{s.E}$. Clinton. It became an independent church in 1973.

In 1924 a program including Chinese and English classes, a kindergarten, and a sunday school was initiated. ${ }^{114}$ In 1947 this kindergarten was still operating, behind a high board fence on N.W. Fourth between Couch and Davis. An article stated that:

Big plans are afoot right now for a combination church and community center, established in cooperation with all social agencies having interests in the district. 115

We have no record, however, that such a center was ever established.

One of the men we interviewed, who provided much of the information above, attended both the Baptist and Presbyterian kindergartens as a child, and told of being collected by white women each morning and taken to school. He said he received much benefit from the people at these missions, in the form of social and educational activities, and informal counseling, which was helpful because his parents were not equipped to guide and counsel him regarding life in America.

\section{SUMMARY}

In this chapter, we have seen that the Portland Chinese community from 1905 to 1943 changed from a bachelor society to a society of families. The Chinese became more familiar with American customs, and an American born generation developed which rejected some of the old Chinese ways. 
Organizations of an American form began to develop, and the traditional Chinese organizations lost membership and became less influential. But the community continued to retain a strong sense of identity with the Chinese heritage. Affairs in China were closely followed, and traditional holidays continued to be observed. Integration with the white community was partially accomplished, but social activities and organizations continued to be limited to activities among the Chinese themselves.

In Part III, we will examine the structure of the contemporary Chinese community in Portland, and attempt to define the goals and the problems of this community. We will also look at the implications of our findings for the design of social services for ethnic and racial minority groups. 
CHAPTER VII: FOOTNOTES

$1_{\text {Helen Lewis Givens, The Korean Community in Los }}$ Angeles County, (San Francisco: R and E Research Associates, 1974; from a thesis written in 1939), p. 24.

p. 21 c. 4 .

2 "Chinese Labor Opposed," Oregonian, Nov. 23, 1919,

3 "The Misunderstood Race Problem," editorial, Oregonian, Feb. 11, 1907, p. 6 c. 3 .

${ }^{4}$ Dorothy O. Johansen, Empire of the Columbia, (N.Y.: Harper and Row, Publishers, 1967), p. 496.

5 Harry H. L. Kitano, Japanese Americans: The Evolution of a Subculture, (Englewood Cliffs, N.J.: Prentice Hall, Inc., 1969), p. 17 .

${ }^{6}$ Marjorie R. Stearns, The History of the Japanese People in Oregon, (San Francisco: $\bar{R}$ and E Research Associates, 1974; from a thesis written in 1937), p. 79 .

7H. Brett Melendy, The Oriental Americans, (N.Y.: Twayne Publishers, Inc., 1972), p. 63; James I. Wong, Aspirations and Frustrations of the Chinese Youth in the San Francisco Bay Area: Aspersions upon the Societal Scheme, (San Francisco: $R$ and $E$ Research Associates, 1977), $\mathrm{p} .14$; and Rose Hum Lee, The Chinese in the United States of America, (Hong Kong: Hong Kong University Press, 1960), p. 14.

${ }^{8}$ Roger Daniels and Harry H. L. Kitano, American Racism: Exploration of the Nature of Prejudice, (Englewood Cliffs, N.J.: Prentice-Hall, Inc., 1970), p. 54 .

9 Melendy, p. 63.

${ }^{10}$ Chia-lin Chen, "The Kam Wah Chung Company Papers. John Day, Oregon," (unpublished manuscript, Oregon Historical Society, Portland, 1974), p. 21l. Translation of a letter dated sept. 16, 1923.

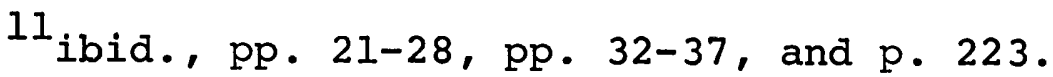

12 "Portland Banquet to Chinese Guests Delayed by U.S. Immigration Rules," Oregonian, May 19, 1933, p. I c. 4-5.

13"Chinese Reared in America is Exiled," by C. H. Williams, Oregonian, April 12, 1916, p. I c. 7.

14 "Government Charges Chinese Cook Weds Sister to Gain Entry Into U.S.," Oregonian, April 25, 1964, p. 1 c. 5-7. 
${ }^{15}$ Melendy, p. 64.

${ }^{16}$ Karen $C$. Wong, Chinese History in the Pacific Northwest, (privately printed, [Seattle?/, 1972), p. 57 .

17 "Chinese Prisoner Cannot Get Bail," Oregonian, Oct. 5, 1910, p. 9 c. 1 .

18 "Smuggled Men Exposed," Oregonian, April 23, 1931, p. 13 c. 2 .

${ }^{19}$ Melendy, p. 64 .

20 ibid. , pp. 65-66.

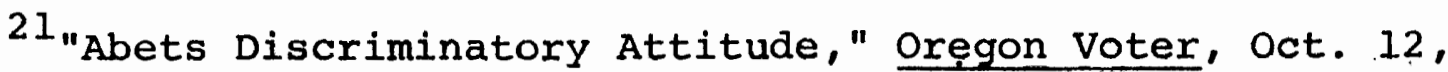
1946, pp. 8-9.

${ }^{22}$ Victor G. and Brett De Bary Nee, Longtime Californ': A Documentary Study of an American Chinatown, (N.Y,: Pantheon Books, 1973), p. 41.

23 Melendy, pp. 65-66.

24 ibid., p. 67; and Bok-Lim C. Kim, "An Appraisal of Korean Immigrant Service Needs," Social Casework, LVII, (March 1976), p. 139.

${ }^{25}$ Rose Hum Lee, Table 10, "Major Occupations of Chinese by Sex, 1940 and 1950," p. 48.

${ }^{26}$ Chia-lin Chen, "Chen Chia-lin's Translations (Articles Written by Portland's Chinese)," (unpublished manuscript, Oregon Historical Society, 1973), pp. 31-33. Translated from an article by Ta-kuei, "My Impressions of Portland's Chinatown," in Sing Shar Monthly, Vol. 1, Nos. 4 and 5, April and May, 1931.

27 Nee, pp. $22-23$.

28 Melendy, p. 56 .

${ }^{29}$ Chia-lin Chen, "Interviews with Some Prominent Members of the Portland Chinese Community," (unpublished manuscript, Oregon Historical Society, 1973), p. 17.

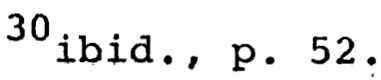

${ }^{31}$ Herbert Hill, "Anti-Oriental Agitation and the Rise of Working-Class Racism," Society, X (Jan./Feb. 1973) p. 52. 
32 ibid., p. 53.

33"Labor Men Demand Asiatic Exclusion," Oregonian, Nov. 19, 1913, p. 6 c. 3.

34 "Sailors' Union of the Pacific Minutes, 1907-1910," (Oregon Historical Society microfilm \#59), Vol. I.

${ }^{35}$ Isabella Black, "American Labour and Chinese Immigration," Past and Present, No. 25, (July 1963), p. 70.

${ }^{36}$ Wei Min She Labor Committee, Chinese Working People in America, (San Francisco: United Front Press, 1974), pp. 29-59.

${ }^{37}$ Ivan H. Light, Ethnic Enterprise in America: Business and Welfare Among Chinese, Japanese, and Blacks, (Berkeley: University of California Press, 1972), pp. 91-92.

p. 5 c. 3.

38 "Chinese Union Rises Up," Oregonian, Sept. 2, 1905,

${ }^{39}$ Chen, "Interviews...", p. 5.

40 Nee, p. 154. See also Melendy, p. 170.

$41_{\text {Bessie Ying Lee, "Perpetuation of Primary Group }}$ Patterns Among the Chinese in Portland, Oregon," (Masters thesis in Sociology, University of Oregon, 1938), pp. 39 and 41 .

42 "Fair Treatment Urged for Chinese Born in America," Oregonian, Jan. 20, 1929, S. 1 p. 12 c. 5-6.

43 Bessie Ying Lee, p. 57.

44 ibid., p. 77.

45 "Chinese Worry Over Vices of Their Boys," Oregonian, June 19, 1921, p. 12 c. 5 .

${ }^{46}$ Bessie Ying Lee, p. 41 .

47 ibia.

${ }^{48}$ Portland figures from Bessie Ying Lee, p. 39 ; United States figures from Shien Woo Kung, Chinese in American Life, (Seattle: University of Washington Press, 1962), p. 33 .

${ }^{49}$ Bessie Ying Lee, pp. 51-52.

$50_{\text {ibid., pp. 91-92. }}$ 
$51_{\text {ibid., pp. } 62-65}$.

52 ibid., pp. 46-49.

53 ibid., p. 59.

54 "Chinese Students Like Volleyball," Oregon Journal, April 24, 1927, S. 1 p. 6 c. 2-3.

55 Rose Hum Lee, p. 355.

${ }^{56}$ Chen, "Translations...", p. 13. Translated from "What I hope for the Chinese Community in Portland," by Chen Ming-tai, in Chinese Language School Quarterly I (June 1921).

57 Percy Maddux, City on the Willamette: The Story of Portland, Oregon, (Portland: Binfords and Mort, Publishers, 1952), pp. 91-92.

${ }^{58}$ Gunther Barth, Bitter Strength: A History of the Chinese in the United States, 1850-1870, TCambridge, Mass.: Harvard University Press, 1964), p. 107.

${ }^{59}$ Chen, "Interviews...," p. 16.

60 ibid., pp. 20-23, Appendix, "The Revised Basic Rules and Regulations of Hop Sing Tong of U.S.A."

61 "Chinese Mourn Departure of Friend and Benefactor," Oregonian, Oct. 14,1933, p. 8 c. 2-3.

62

Chen, "Interviews...", p. 23.

63 "Secrets of Chinese Dives are Exposed," Oregonian, May 22, 1920, p. 21 c. 1.

64

Chen, "Interviews...", p. 3.

$65_{\text {ibid., p. } 23 .}$

66 "Cox Stops Gaming", Oregonian, Oct. 9, 1910, s. 2 p. 18 c. 3.

67 "City Officials Visit Mystic Chinatown," Oregonian, Feb. 5, 1919, p. 18 c. 3.

68 "'Barred-Door' Law Gets Knockout Blow," Oregonian, May 21,1919, p. 5 c. 1.

69 "Four Lottery Cases Dropped as Illegal," Oregonian, August 14, 1924, p. 1 c. 4 . 
70 "Raids Net 11 Chinese," Oregonian, July 23, 1925 , p. 9 c. 2 .

71"'Tong' Wars Mainly Fakes," Oregonian, March 30, 1913, s. 6, p. 3 c. 6-7.

${ }^{72}$ Paul Lum, "A Short History of the Portland CCBA," Oregon Chinese News, No. 46, (March/April 1975), pp. 6-7.

73 "Chinese Consul Given Portland," Oregonian, Oct. 2, 1906, p. 11 c. 3-4. p. 6 c. 6 .

74"China Opens Consulate," Oregonian, Oct. 17, 1933,

75 "Chinese Wear Identity Tags," Oregonian, Dec. 20, 1941, p. 6 c. 6.

${ }^{76}$ Chen, "Translations...", p. 7. Translated from "A Century of Chinese in Oregon," by Chi Fung Wong.

77 "CCBA Papers, 1908-1930" (Manuscript, Oregon Historical Society; MSS 1459), 2. "KMT Papers."

78 "Speakers Urge Revolt," Oregonian, Dec. 14, 1914, p. 4 c. 3; and "Portland Chinese Fight Concessions," Oregonian, Apri 10, 1915, p. 12 c. 1.

${ }^{79}$ Lum.

80 "Red Chinese Fraud. Traps Portlanders," Oregon Journal, Nov. 12, 1951, p. 1 c. 3-6.

$81_{\text {Lum. }}$.

82 Bessie Ying Lee, p. 112 .

${ }^{83}$ Light, p. 88 .

${ }^{84}$ Lum.

85 "Bodies of 260 Chinese Being Exhumed for Trip," Oregonian, July 8, 1948, S. 2, p. 1; and "Bones Stay on Dock; Jail Holds Chinese, Oregonian, May 8, 1951, p. 1 c. 2-3.

${ }^{86}$ Bessie Ying Lee, p. 109.

87 ibid., pp. 109-110; and Appendix, "Translation of the Amendments and By-Laws of the Chinese Benevolent Association of 1932," pp. 127-130.

${ }^{88}$ Bessie Ying Lee, p. 76. 
${ }^{89}$ Chen, "Translations...", p. 7. Translated from Chi Fung Wong, op cit.

90 Bessie Ying Lee, pp. 54-55.

91"Tong offers Reward for Chin's Slayer," Oregon Journal, sept. 10, 1934, p. 2 c. 2 .

92 Bessie Ying Lee, p. 53.

93 "Portland Chinese Sign Peace Treaty," Oregonian, Nov. 3, 1922, p. 6 c. 1.

94 Bessie Ying Lee, p. 58.

95 ibid., p. 71 .

96 "Unique Celebration Held by Chinese in Portland," Oregonian, Dec. 18, 1928, p. 4 c. 2-3.

97 Melendy, p. 81 .

98 "Portland Chinese Unite",Oregonian, Feb. 25, 1921, p. 4 c. 6 .

${ }^{99}$ Bessie Ying Lee, p. 99.

100 "Chinese Are Indignant," Oregonian, Sept. 24, 1922, S. 1 p. $18 \mathrm{c} .1$.

101 "Chinese Urge Uncle Sam to Give Cupid Fair Show," Oregonian, Feb. 22, 1926, p. 5 c. 2-3.

102 Bessie Ying Lee, pp. 99-100.

$103_{\text {ibid., p. } 83 .}$

104 "Chinese Meet Here," Oregonian, June 15, 1926, p. 2 c. 4-5; and "Chinese Students of Coast Meet in Portland Friday," Oregon Journal, June 13, 1929, p. I c. 3.

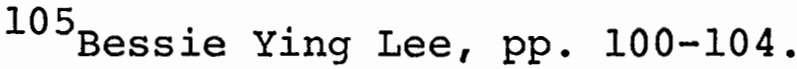

106."Is Chinatown in Portland Going Occidental?," by Mary Patricia Moore, Oregon Journal, Nov. 29, 1931, Magazine Section, p. 5; and "C $\overline{\mathrm{CBA}}$ Papers."

107 Lum.

108 "Our Chinese 'Missions," " Oregonian, June 30, 1909, p. 8 c. 1-2. 
109 "Three Ministers Tie Knot," Oregonian, Jan. 12, 1910 , p. 5 c. 2 .

110 "Twenty-Fifth Anniversary Celebration of Chinese Mission in Portland Will Be Held Friday," Oregonian, Feb. 16,1916, p. 4 c. 2-3.

111 "Where Our Women Do Not Belong," editorial, Oregonian, June 29,1909, p. 8 c. 2 .

112 our Chinese 'Missions,'" Oregonian, June 30, 1909, p. 8 c. 1-2.

113 "Magic, Miracles Key Services," by Ray Wolf, oregonian, July 30, 1950, Magazine Section, pp. 6-7.

114 Chen, "Translations...," P. 6. Translated from Chi Fong Wong, op cit.

115 "High Board Fence Hides Kindergarten Operated by Chinese Presbyterians," Oregonian, Sept. 28, 1947, p. 16 c. 1-5. 
PART III

THE CONTEMPORARY COMMUNITY 
CHAPTER VIII

THE CONTEMPORARY CHINESE COMMUNITY

IN PORTLAND, 1943 TO THE PRESENT

\section{INTRODUCTION}

The present Chinese community in Portland is multifaceted; fragmented, but still cohesive. At present, Chinese community leaders estimate that the Chinese population in Portland is between five and seven thousand persons. This population estimate, if correct, would represent a significant increase since the 1970 census, which indicated 2,462 Chinese in Portland (see Table II). This increase is primarily due to the large number of immigrants who are constantly arriving from hong Kong and Taiwan.

Thus, there are two major divisions of the Chinese community in Portland: the recent imigrants and the longtime residents. The latter are primarily people who were born in Portland; second generation Chinese for the most part, although there is a younger third generation. These people are mainly the children and grandchildren of merchants who came to Portland in the early years of this century. Very few of the old immigrant laborers are left. 
Many of the older members of the community still have a strong sense of identity with their Chinese heritage. It is these older, longtime residents of Portland who are most active in the Chinese organizations.

The younger generation of Portland-born Chinese is less interested in Chinese culture and the Chinese organizations. This group has generally grown up with white, middle-class American culture, most of their friends and schoolmates have been white Americans. There is a tendency among many of the younger Chinese to deny their ethnic heritage; to purposely have as little as possible to do with the Chinese community. But there are other individuals who, while they at first rejected their Chinese-ness, are beginning to gain a sense of pride and interest in their ethnic background.

Another important group within the present Chinese community consists of recent immigrants. This group has grown dramatically since the liberalization of the immigration laws in 1965, but it is still unorganized, and integrated into neither the white nor the Chinese communties in Portland.

There are also' quite a few students from Hong Kong, Taiwan, and other areas who are studying in Portland-area colleges and universities.

We thus see great diversity and many contrasting features in the make-up of the contemporary Chinese $_{n}$ community. 
The Chinatown is gone; the Chinese live throughout Portland, primarily in white middle-class neighborhoods. A variety of life styles, occupations, and attitudes exist. The community is less coherent than it once was. And yet a genuine community is still existent. There are still many organizations, all kinds of projects dealing with mutual support among the Chinese, and, among many Chinese, a real sense of identity with Chinese culture and values. In the following pages, we hope to define and untangle some of these contradictory features of the contemporary Chinese community in Portland.

\section{THE DECLINE OP THE PORTIAND CHINATOWN}

Throughout the years discussed in previous chapters, there was a Chinatown in Portland, which acted as a residence for many Chinese, and as a center for social and other activities for nearly all Chinese. Today, there is little left of the former Chinese presence in Northwest Portland. Many Chinese organizations, including the CCBA, still have their headquarters in this area. There are also a few Chinese restaurants and grocery stores. But the Chinese, except for a few old men, have moved to other areas.

According to a computer print-out based on the 1970 census, only eighty-one Chinese lived in the census tract which included what used to be Chinatown. ${ }^{1}$ It is our observation that even fewer Chinese are still there today. 
Beginning in the late 1940s, and continuing through the 1950s, the old tenements and shops that had made up Chinatown were torn down, and the area began to be developed by white business interests.

\section{The Importance of Chinatown to the Chinese Community}

Writers who have studied the dynamics of the Chinatown phenomenon--how Chinatowns come into being and what causes their decline--seem to agree that a physical center for Chinese residency and activities is necessary if a town is to have a viable Chinese community.

Rose Hum Lee writes of several factors which account for the disappearance of Chinatowns in many cities in the late 1940s. Based on an analysis of demographic data for twelve cities, she concludes that in order for a Chinatown to continue to exist several conditions must be met, and also defines some conditions under which Chinatowns tend to disperse. For instance. Lee says that as the sex ratio becomes more equalized, the Chinese begin to disperse, and Chinatowns disintegrate. ${ }^{2}$ We have seen that in Portland, the Chinese did begin to move away from Chinatown when the sex ratio became more equalized, and families began to form.

Rose Hum Lee also says that the economic structure of Chinatowns can be undermined as a result of war or depression. 3 The Depression affected the Portland Chinatown in this way; many businesses closed, and the area ceased to perform its function of providing jobs for the Chinese. 
A third factor mentioned by Lee, and applicable to Portland, is invasion of the Chinatown by business interests or new population. 4

All of these factors many have been involved in the dispersion of the Chinese in Portland; but there is an assumption made by Rose Hum Lee and others that does not apply here. This is the idea that the decline of a Chinatown will also result in the disappearance of Chinese community institutions and organizations. As Rose Hum Lee puts it: "The decline of a community is manifested in the disintegration and a disappearance of its cultural and social institutions...".5 And Bessie Ying Lee predicted in 1938,

When the Chinese are allowed to enter into the general current of American life freely, the primary group patterns of the Chinese will have no function to perform: therefore they will die a natural death.6

To a certain extent, the end of the Chinatown in Portland has had the effect of making contact between Chinese difficult. One man told us: "We're all separated today. This is the thing about Portland. We'ce so scattered we don't even know each other hardly anymore."

But in Portland, the end of Chinatown and the integration of the Chinese into American society has not meant the complete end of the Chinese community, its institutions and organizations, or its identity. It is 
our contention that this continuation of a Chinese community, even in the absence of a physical center for that community, is in large part due to the efforts of the various Chinese organizations in Portland. This idea will be discussed further in the sections of this" chapter devoted to Chinese organizations. The Dissolution of the Portland Chinatown

The dissolution of the Portland Chinatown was a process that took place over a long period of time. We saw in the last chapter that this process began in the 1930s, when many families moved away. The process accelerated with the new job and housing opportunities available to Chinese after the Second World War. Our interviewees have told us that by the 1950s, there were still many Chinese in Chinatown, but they were mostly the old, bachelor men.?

As we shall see, Chinese organizations such as the CCBA have been continually interested in a revival of the Chinatown as a tourist sight or business district. There was also a proposal in 1961 for a housing project for the old Chinese men. At the present time, none of these ideas have proved viable, although planning by Chinese leaders continues.

The end of the Chinatown as a residential center came in the early 1960s, when the last of the old buildings was torn down to make way for a parking lot. 8 
Present Conditions in the Chinatown Area

Today, some Chinese organizations continue to own buildings and have headquarters in this area. There are also a few Chinese restaurants and grocery stores there. But very little of the old district is left. "They all moved away," said one of our informants, "Uhinatown is really not like it used to be. Hardly any Chinatown left."

The area north of Burnside is now Portland's equivalent of a skid row, and is dominated by cheap hotels, bars, rescue missions, and social service agencies. It also contains a small row of new shops and restaurants designated nuld Town". Parking lots and gas stations have replaced many of the old buildings.

The buildings still owned or operated by Chinese, such as the CCBA building at 315 Northwest Davis, the Hop Sing Tong building at Fourth and Flanders, and others, were built around the turn of the century and are now in very poor shape.

But in a diminished way, the presence of the few stores and organizations continues to make the Burnside area a meeting ground for Chinese. Many Chinese still shop at the grocery stores in this area, for instance. Banquets and parties are held in the restaurants. And on Saturday mormings, the Chinese Ianguage School on the second and third floors of the CCBA building is crowded with people--both children going to the classes, and 
their parents, who often linger in the hallways talking to friends.

LIVING CONDITIONS AND EXTENT OF CONTINUED

\section{DISCRIMINATION}

Due to an unavailability of demographic data on the Chinese, it was impossible to obtain precise data on income, employment, and education levels of the Chinese in Portland. As demonstrated by Figure 7. most Chinese in Portland now live in the Southeast, and there is a large concentration in the area around Iadd Circle. This is a predominantly white, middle-class district of large but older homes. Of the Chinese with whom we have had contact, all--including immigrants and students--lived in adequate homes or apartments.

Many of the Portland Chinese--perhaps most--are college educated. There are many professionals. Several organizations of Chinese professionals exist, designed primarily for mutual support among the recent immigrant professional group. In general, it appears that Chinese in Portland have been welcomed into the white middle-class. But on further investigation, it becomes necessary to qualify this impression somewhat.

Continuation of discrimination

Numerous success stories of Chinese who have made it in white society are available. Portland-area colleges and universities include several Chinese professors. There 


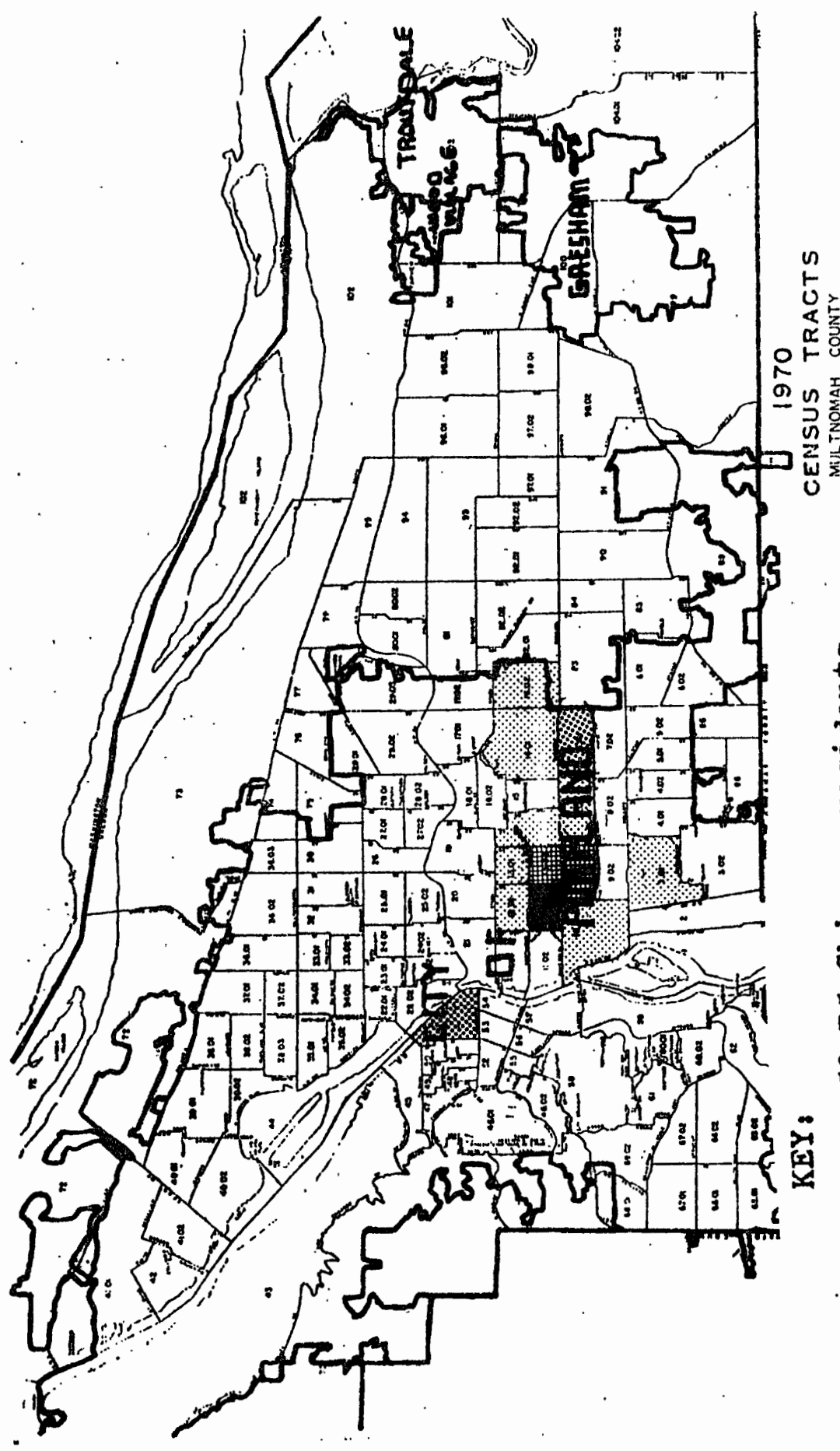

要

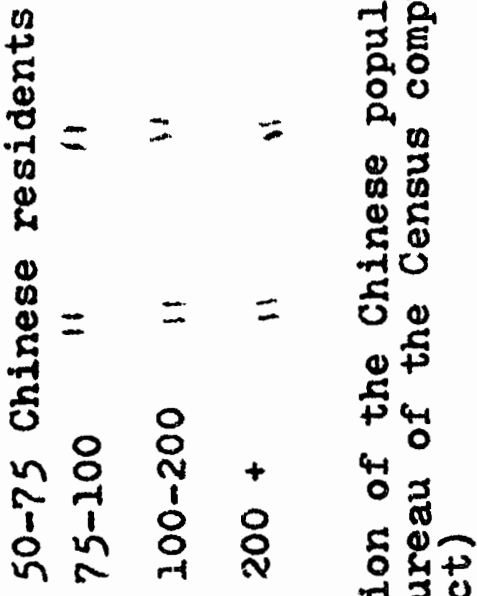
†ु है 4रि सक के of a مै 
are Chinese engineers. lawyers, ingurance agents, and doctors in Portland. Both our own and Chia-lin Chen!s interviews with prominent Chinese in Portland provide. several stories of men who worked their way to successful careers after much adversity.

But most, although not all, of our interviewees agreed that discrimination, in a subtle form, continues to exist today. "Some of it can be very silent and subtle"" said one man, "It's not as open as it used to be." An interesting phenomenon that we observed in our interviews was that some people would openly speak of discrimination against Chinese, while others were surprised that we would even ask about the subject, and some were openly hostile to the very idea that discrimination might still exist. Investigatory panels in both Washington State and California have concluded that "racism has and still does exist against Asians. $n 9$

There is also a continuation of race consciousness in American society: people continue to act differently towards non-whites than towards whites. One of the successful professional Chinese we talked with pointed out that this fact has both advantages and disadvantages. In business, in meetings and so forth, a Chinese person stands out. Our informant observed, for instance, that at Rotary Club meetings he is thought of by others as the "Chinese member". Such attention because of race may be a disadvantage at times, but our informant also 
pointed out that because of this he may be remembered by potential clients.

Another man told us that the CCBA frequently gets calls from employers looking for minority workers to satisfy affirmative action requirements. Continued distrust of blacks by some white Americans, and the old stereotype of Chinese as hard and obediant workers probably gives Chinese an advantage in such situations.

There continues to be a racial stereotype of Chinese, but most of these stereotypes today are of a positive nature. Asians are thought of a bright, studious, professional people. One of our informants thought this had a negative aspect in that it put great pressure on children for academic achievement. But while some Chinese children undoubtedly do experience pressure to study hard, this is not only a result of trying to live up to stereotypes; but also a result of the traditional high value placed on scholarly achievement by chinese culture.

Discrimination in Employment

Daniels and Kitano provide some interesting statistics on Chinese income levels. They say that a college degree is $24 \%$ more frequent among Chinese than among whites, but that for every $\$ 51$ a white Californian makes, a Chinese makes only $\$ 38$. 10 The belief has been widely held that minorities can advance their status through better education. The Chinese have capitalized on this 
idea, and have placed great stress on providing education for their children. But according to the above statistics, these efforts have had only limited success.

An observation made by several writers is that Chinese can obtain high-level staff positions, but are blocked from top executive or leadership positions. 11 Dean Lan says that this is because,

...the older stereotype that Chinese could not assume positions that had public contact because of English difficulties has been followed by the notion that chinese could not supervise the work of others.12

One of the men we interviewed, who is a public employee, said that the Chinese in Portland are well trained and have no difficulty finding good jobs.

But it's my observation that you don't go very far... In the upper positions, they're all held for whites; not even women... It's my impression that you don't have to be competant as long as you're white.

The Washington state investigatory panel referred to above cites many instances of outright job discrimination against Asians, and continued discrimination by labor unions. 13 We did not discover any such instances in Portland, but neither can we say that job discrimination does not exist.

One employment pattern which is conspicuously lacking in Portland today is the restriction of chinese labor to pre-industrial and menial segments of the economy. Although we have no statistics on the matter, it appears from our observations that only a small 
percentage of Chinese in Portland work at menial jobs. There are still Chinese working in the salmon canneries along the Columbia; there are Chinese, mostly young people, who work in the many Chinese restaurants in Portland; and there are some women textile workers. But such work is no longer a major area of employment for Chinese, even the recent immigrants.

In the Chinatowns of San Francisco and New York, this situation is very different. The Chinatown structure allows for greater control of employment by business elites; and a system of internal colonialism continues to exist. The garment shops of San Francisco are a notorious example of continued exploitation of Chinese labor. The Nees document a system which includes poor working conditions, long hours, and pay levels below the minimum wage, controlled by white-owned textile concerns outside Chinatown. 14

Housing

Recent years have also seen the end of housing discrimination against Chinese; and this, combined with the opening up of employment opportunities, has allowed the Chinese in Portland to move into white middle-class neighborhoods.

Chinese in Portland waged a successful struggle against housing discrimination in the late 1940s. In 1948. deed restrictions aimed at keeping out people of 
color still existed in many Portland neighborhoods. One man told us of his attempts in that year to buy the house he now owns in Northeast Portland. He was prevented from buying in his own name, but was able to buy in trust. He describes this instance as "The one and only time I really felt injustice and discrimination." Other people also told us of problems in buying houses in Northeast Portland.

A woman told us of her brother, who fought in World War II. Upon his return, he tried to buy a house in Iake 0swego, but the neighbors petitioned against him and he was not allowed in. Because he was a recentlyretumed veteran, however, his case got public support in the newspapers and from the general population, and the neighbors backed down.

In December of 1948, the US Supreme Court ruled that deed restrictions based on race were unconstitutional, and Chinese had less trouble buying houses wherever they wanted after this time.

There is evidence that discrimination in housing against Asians still exists in some areas. 15 Education

We have mentioned several times the high value placed on education by the Chinese. It is seen as the best way of achieving social mobility. The poor, immigrant laborers who came to America accepted that they would 
probably never have a good job or a nice home. But they attempted to ensure that their children would be better off, and they did this through sactifieing all they could to educate their children. This characteristic has obvious roots in traditional Chinese cultural values--the high status accorded to the scholar, and the emphasis on devotion to family over the individual.

Department of Health, Education and Welfare data on population characteristics of ethnic minoritieg in Region X (the study unfortunately inciudes data on the Chinese only for the Seattle SMSA), shows $71 \%$ of the Chinese aged 18 to 24 in school. presumedly mostly at the college leval. This compares to a figure of $34 \%$ for the general population. 16

We have seen that there used to be segregated schools for Chinese in Portland. The Chinese apparently had little trouble getting into oregon colleges and universities, but one of Cheris interviewees tells of discrimination in the granting of scholarships and in the assignment of Masters theais topics at a university he attended in the late 1940s. 17

Schools in Portland are no longer segregated, and there is little or no discrimination against Asians in education. Children of immigrants do have problems with English, but the Portland school system has an Asian Bilingual Education program that helps such children. 
The project is neither well-staffed nor well-funded, but there is a teacher and a teacherts aid with knowledge of Cantonese, the dialect of the Hong Kong immigrants; and another teacher's aid who knows Mandarin, which is the dialect spoken in Taiwan. There are currently fifty to sixty Chinese students being served by this project. Thus, the living situation of the Chinese in Portland has greatly improved over the past thirty years. Most Chinese are well-educated, have good jobs, and good housing. Some forms of discrimination still exist. but they are of a subtle form and are discounted by many Chinese. The conditions of exploitation and hostility against Chinese that formerly existed are now almost entirely gone in Portland, although they continue to exist in some of the larger Chinatowns.

SOCIAL PROBLEMS OF SEVERAL GROUPS IN THE

CHINESE COMDUNITY

Problems in other Cities

Partly because of the integration of the Portland Chinese into the broader society, and the lack of a Chinese ghetto in Portland, this city is without many of the problems existing in Chinese communities in other cities. An examination of such problems will give us a basis for comparison with the situation in Portland.

It should be noted that Chinatowns still exist in many cities, the largest being in San Prancisco and New York. 
Iiving conditions and opportunities are poor in these ghettoes. In the San Francisco Chinatown, the population density is 885.1 persons per acre. 18 One-third of the population in 1970 was below the poverty level in income, 12.8\% were unemployed; $67 \%$ lived in substandard housing. 19 Health care is inadequate; there is only one sixty-bed hospital in Chinatown to serve a population of 40,000.20 The San Francisco Chinatown has one of the highest rates of tuberculosis and of suicide in the nation. 21

Mental health is also a problem in Chinese communities. Reluctance among many traditionally-oriented Chinese to take problems outside of the family; distrust of services dominated by the majority culture, and a lack of culturally sensitive services compound these problems. 22 Availability of mental health services in the Chinatowns is also a problem. The Nees state that as of 1969. there were only two Chinese-speaking psychiatrists in San Francisco. 23

The Chinatowns in San Francisco and New York act as clearinghouses for recent immigrants; and the rate of immigration has risen dramaticaliy in recent years. Some of these individuals are skilled professionals. Others are unskilled workers. Because of lack of knowledge of English, lack of professional accreditation recognized in the United States, and other reasons, many of these 
immigrants rely on the traditional areas of employment offered by Chinatowns--restaurants, laundries, garment shops. It is estimated that less than $40 \%$ of the Chinese in California can speak fluent English. 24

The oppression and frustration inherent in such living conditions has resulted in some violence and criminal activity. The youth gang wars in the fall of 1977 in San Francisco are a well-publicized example of such violence, but youth gangs, some oriented towards street violence and petty crime, others towards social action, have existed since the early 19608 in Chinatowns in both San Francisco and New York. 25 There also continue to be allegations that the tongs in these Chinatowns are still involved in illegal activities. 26 The Aged

Problems in the Chinese community in Portland are few, but not non-existent or unimportant. One of the major problem areas for Asians, not only in Portland but throughout America, is the problems of the elderly.

The traditional pattern through which Chinese cared for their aged parents has to some extent broken down. Pei-ngor Chen observes that:

In the past, the collective efforts of nuclear and extended family systems cared for the Chinese aged. At the present time, both the old and the young Chinese people feel morg, comfortable when they live in separate households. 27

In Portland, many of the recent immigrant families include parents of the head of household; but most of the 
long-term and Portland-born residents do not. Many elderly

Chinese live alone. Some are in nursing homes.

Pei-ngor Chen reviews some of the problems common

to elderly Chinese:

Having lived in Chinatown all their lives, the elderly Chinese have not learned the English language. In addition to loneliness, ill-health, and the deep sense of hopelessness common to most old people, their problems are intensified by the language barrier. 28

They are also subject to problems with health, housing, and income. They are reluctant to apply to public agencies for aid; and because of lack of knowledge of local social services and lack of knowledge of English, they find it difficult to obtain services even when they want to receive them.

A service of the CCBA, which is now organized officially as the Chinese Information Service but which has always existed informally, provides information and referral to Chinese, mostly senior citizens and immigrants, who ask for help. They also accompany Chinese to public agencies to help them apply for services.

Two groups of the aged Chinese in Portland experience special problems, Those in nursing homes, and the few older Chinese who still live in tenements in the Burnside area. The Chinese in nursing homes have problems because of poor knowledge of English and because of food. They do not communicate well with other residents or with 
staff, and they find it hard to get used to Western food.

The CCBA has attempted to provide some services for these elderly Chinese. In 1972, the CCBA's Welfare Committee instituted a program of visiting Chinese in nursing homes, and looked into the idea of sponsering a Chinese nursing home in Portland. They were told, however, that such a nursing home would not be eligible for federal funding if it was restricted only to Chinese. The Chinese Womeris Club also makes a yearly visit to the Chinese in nursing homes. One woman told us that she and her sister used to go by themselves on visits to the Chinese in nursing homes between 1972 and 1974. They brought them Chinese food, and talked to them in Chinese. She said they would never visit any Chinese who had families, because Chinese culture would see this as intruding. She also says that today there are only a few Chinese left in Portland-area nursing homes. There are also very few elderly Chinese still living in the Burnside area, but these people are in a destitute situation. We contacted several social service agencies in the Burnside area. They told us that there are still some aged Chinese living in the Foster Hotel. Some of these people know little or no English. Some have problems with alcoholism or mental health. All have little money, and no family in Portland. 
The same woman mentioned above told us of a 1972 visit to a man close to 90 years old who llved at the top of the stairs in a tenement building that was torn down in 1977. She salds

When I went into his room. I was really surprised. It was a room, and there was a ladder where you climbed into the loft, his bed was up above. And he had a urinal still in his bedroom. He had a lot of apple boxes; thats what he ate on.

She was shocked by these conditions, and felt that the Chinese community should do something to help these people. But she says that now most of these people have moved to better areas, or into nursing homes. Immigrants

In the large Chinatowns that still remain, recent immigrants constitute the group with the most social problems. The children join youth gangs; the adults know little English and have trouble finding work. Portland has had a big influx of Chinese immigrants over recent years; but to our knowledge the immigrants here have been much better prepared for life in America. Many, although certainly not all, are well-oducated professional people. They have little trouble finding jobs or housing. although they inevitably have problems with the English language.

We have mentioned that the liberaliration of the immigration laws have led to a huge increase in the number of Chinese and other Asian immigrants coming to the 
United States. The number of Chinese immigrants with permanent residency status in the United States increased from 4,057 in 1965 to 17,339 in 1972, an increase of $327 \% .29$

This group of immigrants is much different than those who came to this country in the nineteenth century. They enter as families, rather than as single men. They are primarily urban Chinese, rather than rural. They are generally well-trained (it is easier to get a visa if one has training and education). In $1970,3,715$ of the Chinese immigrants to Califormia were professionals, compared to 2,098 service workers. 30 It is our impression that the percentage of immigrants to Portland who are professional is even higher. The president of the CCBA says that most of the immigrants in Portland are from Hong Kong, the Chinese from Taiwan are mostly students, businessmen, and govermment representatives, not permanent residents.

The motivations and expectations of these immigrants are varied. Many arrive with an unrealistic picture of the possibilities for success in America. A San Francisco Chinese immigrant interviewed by a radical Chinese newspaper stated it this way,

Q. What did you think of the US when you were in Hong Kong?

As I thought that the US must be ten times better than Hong Kong. I saw movies and heard what people said. They all said it was a free, democratic, prosperous country. So everyone in Hong Kong dreamed of coming to the US to make a living. 31 
Some of the people from hong Kong who we interviewed said much the same thing. One person told us:

In the persons imagination, everything will be fine, everything will be good; but when you go to the United States, you may be disappointed... Take my father as an example. He doesit know English, and almost the only job is working in a Chinese restaurant.

Thus, hope for a better life, at times based on unrealistic expectations of the conditions in America. is probably the primary motive of these immigrants. There are, however, a variety of other motivations. One of these is reunion with relatives who previously came to the United States. One can observe a pattern of immigration whereby one person will come to America, and a few years later will bring over others of his family, until a whole extended family group of children, parents, grandparents, uncles, and aunts is living in the same town.

The first wave of immigrants coming to America in the 1950s, after the lifting of exclusion, were refugees from the Communist takeover of China. There is still a trickle of immigrants motivated by political conditions to come to America. One man we talked to left Burma after a takeover by a socialist military government there in 1962. He went to Taiwan in 1968, and spent six years there until his visa was approved to come to Portland.

We have mentioned that most of the recent immigrants are highly educated, but this does not guarantee that they 
will find a job easily. Many times professional certifications or degrees received overseas are not accepted in America. As one writer puts it,

Without American degrees, it is difficult for persons with a Chinese college education in social sciences and humanities to find professional jobs in the United States....32

We have encountered some instances of immigrants in Portland who had difficulty finding jobs, such as the family mentioned above whose father worked in a Chinese restaurant. One of the volunteers for the Chinese Information Service said that she knows of many immigrants who have had trouble finding work, and told us of recently helping a young girl apply and interview for a job. The girl was rejected because of poor knowledge of English.

In general, however, most immigrants in Portland do find good employment. The Chinese Consul in Portland, Patrick P.C. Cheng, said that the recent immigrants are well-educated, well-equipped with skills, and "get into different things other than restaurants."

One of the immigrants we interviewed said that he thought there were many employment opportunities. He was laid off for one short period during his three years in Portland, but has otherwise found employment in his field (engineering). His wife works as a seam-stitcher. Several of his neighbors are also Chinese immigrants, and they have all found jobs. 
There are many problem areas for these recent immigrants, however. The most serious of these problems is of course, knowledge of English. There are some organizations in the community that teach English to the immigrants, and most have studied English before their arrival in America. But English is a very difficult language for a Chinese-speaking person to learn (and vice versa).

Lack of good English-speaking ability is not only a liability in seeking employment, but also a cause for some discrimination. Some Americans react with incomprehension or even hostility to foreigners with even slight accents, perhaps from inability to understand less than perfect English, and perhaps from prejudice. Several of the immigrants and foreign students who we talked to said that they felt Americans were unfriendly to foreigners.

English classes are provided to Chinese immigrants by Portland Community College, by several of the Chinese churches, and by the CCBA. One of our interviewees spoke of the advantages of having English instruction provided by the Chinese community, rather than by outside agencies:

We will have a lot of people who may be very excellent in one area, but because of lack of English they need to find jobs... So in that area we find it's necessary for them to come to an association like us /within the Chinese community , because they are very shy about going out.

Culture shock is a serious problem for some of the immigrants, although others seem to have few difficulties. In any case, difficulty in adaptation to 
a strange and at times frightening new environment is to a greater or lesser extent present for all the immigrants we talked with. They mentioned problems in getting used to the food, the weather, the life style, the people-all aspects of American life.

These problems are to some extent mitigated by the fact that most of the recent immigrants come here with their families, or meet relatives already resident in Portland. Most of these families still speak Chinese in the home, eat Chinese food, and observe Chinese values and culture. The mutual support present in the family situation is undoubtedly very helpful in coping with living in America.

There is a minimal amount of contact between the established Chinese community and the recent immigrants. In fact, the two groups have less in common than one might expect. The China from which the recent immigrants come is very different from the China which formed the cultural traditions of the long-term residents; and the latter group has of course been Americanized to a great extent. Few of the long-term residents we talked with had had much contact with the recent immigrants.

But the established Chinese community has provided some programs of service to the new arrivals. One such service is the Chinese Information Service, which we have 
mentioned earlier. Several volunteers at the CCBA have always provided information and referral services, and have accompanied people to apply for jobs or social services. In June, 1977, the Chinese Information Service received six months of funding from the federal Comprehensive Employment Training Act (CETA). Two full-time staff people were hired to work on a directory of local services appropriate to the Chinese. A needs assessment survey distributed through the Chinese churches was done in December and January of 1977-78 to determine the contents of this directory. The phones for the information and referral services are only manned four hours a week currently, because of lack of manpower, but phone recorders are used and checked several times a week .

Although these services are raluable, lack of resources severely limit the number of clients that can be served. Only a few people a month can be accompanied to agencies by Information Service staff or volunteers.

Another source of aid and mutual support for new immigrants comes from several Chinese professional organizations, which will be further discussed later. The first of these groups is the Chinese Scientists and Engineers Association, founded in 1972 by a Chinese 
consulting engineer who was then the president of the CCBA. He said he observed that many of the recent immigrants were engineers, and "I felt they had no common point of communication." He wanted to bring them into the Chinese community. A Chinese Physicians Dentists Association was formed in 1977.33 The membership of these groups consists mainly of recent immigrants who are professionals, and the organizations serve as support groups and provide social activities for these people.

Some of the Chinese churches in town also provide some services, primarily in the form of English classes, for the new immigrants. The services offered by these churches will also be discussed more later.

The Chinese Consulate in Portland exists specifically to look after the needs of Chinese nationals from Taiwan. It cooperates closely with the CCBA, helps immigrants find English classes, and provides aid in resolving problems of immigration and residency status. Students

There are several hundred Chinese foreign students in colleges and universities in the Portland area. Their problems are similar to those of the recent immigrants; but their situation differs from that of the immigrants in several important respects. First, they are students, 
not permanent residents. They are young. They are also for the most part alone, whereas most immigrants come with their families.

We talked with several of these students, and they expressed many reasons for coming to the United States to study. As with the immigrants, the students can be divided into those who come from Hong Kong--the majority--and those from Taiwan. Characteristics and motivations are different for these groups.

The students from Taiwan who we talked to felt that they could get a better education in America than they could in Taiwan. An American degree carries great prestige in Nationalist China, and ensures a good job and rapid advancement. One student from Taiwan said that she came to the US because she enjoys the freedom here, both socially and politically. She felt that she was unusual in this respect, but a 1976 study of Chinese students at Portland State University by Kim Bik Au shows that twenty-five of thirty students surveyed mentioned freedom and independence as one of the positive experiences they had had in America. 34

Students from Hong Kong also mentioned the prestige of an American education as an important motivation. But unlike Taiwan, there are universities in Hong Kong that are as good as the best universities in America-- 
Hong Kong University, for instance. Graduates of the Hong Kong schools have priority in getting government and other jobs there. But competition is heavy for the few spots in the universities in Hong Kong. The alternative is an education in America. Going to college here is thus not the most prestigious form of education for the student from Hong Kong; it does not ensure the graduate the best jobs. But an American education does guarantee prestige, and good employment opportunities.

Most of the Chinese students, from both Hong Kong and Taiwan, come from middle or upper class families. They are thus not typical Chinese; and their families are Iikely to be already Westernized to a certain extent. Due to the status of their families few Chinese students have financial difficulties in the United States. Many of these students also receive financial aid or work part time. 35

As with the immigrants, the main problem for Chinese students is language. All foreign applicants to American universities must make an acceptable score on a standard test of their English ability. This generally ensures that they know enough English to understand lectures and read textbooks, although writing papers is often difficult for them. But most Chinese students find it difficult to speak English well enough to $\mathrm{mix}$ socially 
with Americans. In the Au study, language was the most frequently mentioned frustration of living in America. 36

Culture shock and adjustment problems were also frequently mentioned as difficulties by our interviewees; although, as with the immigrants, a few students said they had had few adjustment problems.

Lack of a social life is another frequently mentioned problem. Several people told us they felt they were ignored by their American classmates. One person says:

They think that I don't understand at all and talking to me is nonsense. So I am sometimes very mad in class, but I don't have a chance to tell anybody.

Most of the students we interviewed said their friends were mostly Chinese. They said they felt more comfortable among their fellow Chinese students, and could gain support from them.

Despite these problems, nearly all of these students would like to stay in the United States after graduation. One person we talked with said she knows of only one Chinese student who did not want to stay in the US. Another student said he felt that $75 \%$ of the Chinese students want to stay here. Because they came to America on temporary student visas, this desire to remain is a major problem. Students must line up a sponsor or an employer if they are to have any chance of getting a permanent residency visa. There is little 
help available to students who want to remain in America; they have to find their own ways of staying.

There are three organizations of Chinese students in Portland--two at Portland State University and one at the University of Portland. The Chine Students Association at PSU was: formed some years ago, perhaps in 1966, if we correctly interpret a note in the Oregon Chinese News in that year. 37 In September of 1976, the Hong Kong students separated from this group and formed a separate Hong Kong Chinese Students Association. The primary reason for the separation was language. The Hong Kong students speak Cantonese, while the Taiwan students speak Mandarin. An additional reason was differences in culture. The Hong Kong students are more liberal; they like to hold dances and informal parties. The Taiwan students are more formal and traditional.

The Hong Kong Chinese Students Association currently has about seventy active members. The Chinese Students Association at PSU (the Taiwan group) has about twenty members. The organization at the University of Portland has about thirty members.

The purpose of all of these groups is similar--to provide a support group for the Chinese foreign students 
and to organize social activities. The president of the Hong Kong Chinese Students said: "Our main purpose is to help the new students from Hong Kong to adjust to the environment." They try to help these students register, find housing, etc.

But the major activities of these groups are social, consisting of movies, dinners, parties, etc. Both PSU organizations held Iunar New Year's celebrations in 1978. That of the Taiwan group was a lavish party, with over six hundred people in attendence, including many of the leaders of the Chinese community in Portland. There was a banquet and a program of Chinese songs and dances. The Hong Kong group held a dinner and dance party, with few people outside the association in attendence. The difference in these affairs points up the differences between the two groups. The Hong Kong group is more informal and more Westernized.

Youth

We saw in the last chapter that always, from the time an American-born generation first developed, the Chinese in Portland have been concerned that their young people might drift away from Chinese culture and identity. Thus far, the Portland Chinese community has managed to retain its sense of identity through several generations. 
But today, with the increasing integration of Chinese into the broader society, fears of the traditional Chinese about the rejection of traditional culture by the younger generation seem well justified,

In the Chinatowns of San Francisco and New York, there are major problems with youth gangs and juvenile delinquency. This is in part due to a breakdown in the traditional Chinese family structure and loss of traditional values--a process that has occurred in Chinese communities everywhere in America. But it is also due to the oppressing big-city ghetto conditions present in these Chinatowns and lacking in communities such as Portland. 38

Portland has therefore escaped the problems with juvenile delinquency present in some of the large Chinatowns. An article in the Oregonian cited a Portland police claim that the Wah Ching youth gang attempted to set up a branch in Portland around 1974 and 1975. It also quoted Bruce Wong, one of the leaders of the Portland Chinese community, as saying:

The guys who were causing problems either moved or found work. Portland simply doesnt have the socio-economic problems that you see in San Francisco. 39

Some of the people we interviewed said there are some Chinese juvenile delinquents in Portland, but "not to a large or significant degree."

There are problems with the immigrant youth due to difficulties in adjusting to American schools, and a 
growing lack of communication with their parents.

But the primary characteristic of the Chinese young people in Portland--whether or not it is a problem is a matter of opinion-wis their identification of themselves as Americans rather than Chinese. James Wong refers to this as an "increasing identity crisis among the young people." 40 Many of the Chinese youth seem to feel uncomfortable with their Chinese heritage, but also not completely comfortable or accepted as Americans. This has been referred to as the "marginal man" phenomenon. Wong describes it thus:

The marginal man arises in a bi-cultural or multicultural situation with a natural desire to advance toward the dominant group occupying the higher status. 41

And the Nees quote Frank Chin, a Chinese writer and teacher:

The either-or thing is right in the scientific name we go by. "Chinese". hyphen, "American". At San Francisco State.... I asked the students if they could divide themselves into what they thought were their American and Chinese qualities. Fold a piece of paper in half, the right half would be American, the left half chinese. Everything that was interesting, adventurous, original, creative, fun, sexy, daring, artistic, was American. Everything old-fashioned, inhibiting, restraining, dull, repressive, uncreative, stultifying, was Chinese. 42

Some of the older Chinese we saw were concerned about this phenomenon among the youth in Portland. One man told us: "Most of our young people today see themselves as American Chinese. I see myself as a Chinese American. Theres a difference." Several of the older 
people complained that their children could not speak Chinese, or did not respect them.

We observed an ambiguity of attitude, and a drawing away from all things Chinese, in several of the young people we talked to. One young woman, borm in Hong Kong, said she felt out of place around other Chinese. "I was pretty reluctant to make friends with Chinese--I don't know why." She also said she does not like to tell people where she's from. "Maybe Im ashamed." Another Chinese woman spoke of serious problems due to this sort of "marginality". She left her home in Oakland to go to school in Portland in a conscious attempt to get away from her family, and for a time received counseling from a psychiatric social worker. She sajds "Very frankly, In not altogether comfortable when I talk to Chinese." But she also regrets her lack of understanding of Chinese culture. "I don't have that kind of roots and it's kind of strange." She is thus consciously attempting to regain contact with her heritage. which she feels necessary in order "to be the most whole person I could be."

It is interesting, and perhaps illustrative of the conditions outlined above, that there are no Chinese youth gxoups currently existing in Portland. This can be compared to the profusion of youth groups we discussed in Chapter. VII. There have evidently been a couple of 
attempts in recent years by the CCBA to organize youth activities, but to our knowledge these groups have not lasted long. A Chinese Executive Youth Council operated over the summer of 1966, and organized dances and various service projects, such as waxing the CCBA hall. 43 In December of 1973, a Wah Ching Youth Club was formed. We are unsure whether this group was connected with the youth gang in San Francisco. The reference to it in the Oregon Chinese News implies that it was simply a social group. 44

CONTINUING SENSE OF COMMUNITY AMONG THE CHINESE

As we have seen above, there appears to be a breakdown in the traditional Chinese culture, norms, and values in the Portland Chinese community. And yet, at least among the older Chinese, there is a continuing sense of community, and the retention of their culture is still highly valued.

A 1974 study by Linda Fong of the Chinese in the San Francisco area shows that while $90 \%$ of her sample were not members of Chinese organizations, $90 \%$ thought that Chinese people should learn the Chinese language, 90\% celebrated the Chinese New Year, $90 \%$ said they ate Chinese food often, and $59 \%$ were sympathetic or highly sympathetic to Chinese values. 45 Fong's sample was small and perhaps not representative, and in any case refers to San Francisco, a Chinese community very different 
from Portland. But the very high percentages recorded are at least suggestive, and the indication that $90 \%$ of the sample were not active in Chinese organizations suggests that such activity is not an essential condition for the retention of a Chinese identity.

Many of the people we interviewed were brought up by immigrant parents, attended the Chinese Language School, and while being highly Americanized themselves, still value their heritage as Chinese. One man said, "I am very proud that In Chinese... I think its a disgrace for someone whds Chinese to not speak Chinese." He pointed out with pride that the Chinese are now an important nation in the world. Another man saids "In spite of my leaving the ghetto... I have never broken my ties with Chinatown." He feels closer to the people he knew in the old days than to the white people he knows now through business or socially. A woman told us that Chinese today are getting more Westernized, but "In the back of your mind you still want that Chinese culture." Another woman told about her daughter, who was asked if she didn't think it was strange to go to Chinese language school. She replied, "No, In proud to be of Chinese heritage, because I know what I am. You don't know what you are, do you?"

Some people spoke of the advantages of being bicultural--taking advantage of American culture while retaining an identity as Chinese. "A double culture 
is a double blessing," said one man. Several people described themselves as "half Chinese and half American". Other people spoke of their fears that Chinese cultural traditions would eventually be lost. Most people said they had both Chinese and American friends; some said they mixed socially with Chinese more than with Americans.

Only two of our interviewees felt that Chinese should become completely assimilated into American culture. One was a young person, the other a recent immigrant.

Chinese customs and holidays are still observed in many Chinese homes. Although there is no longer a big Iunar New Years parade through the streets of Chinatown, with tons of fireworks, several Chinese organizations hold well-attended dinners and celebrations. The CCBA holds an annual celebration of Double Ten, the Nationalist Chinese national day on October 10 (the tenth day of the tenth month).

Several of our interviewees have visited Hong Kong or Taiwan in an attempt to regain contact with their ancestral culture.

Intermarriage has been suggested by some writers as a criterion for determining whether a group has been assimilated. 46 Although inter-racial marriages among Chinese are becoming more common than they used to be, most existing Chinese marriages are to other Chinese, and there is often pressure on young people 
not to marry a non-Chinese. But this situation is changing. In Oregon, two-thirds of the Chinese and Japanese men who married in 1976 were married to white women. 47 We assume, however, that Japanese, being generally more assimilated than the Chinese, accounted for many of these inter-racial marriages.

The Chinese in Portland continue to place a high value on helping each other, as indicated by the programs and services reviewed earlier in this chapter. There are several indicators of the continuation of a sense of community among the Chinese in Portland. The first is the continued existence of a Chinese Language School (actually, there are several such schools, as some of the Chinese churches also have classes in Chinese). In many cities, Chinese language schools have suffered from decreased enroliments. 48 In Portland, the CCBA school currently has an enrollment of 110, which is about the same enrollment it had in the 1930s, and is up from an enroliment of eighty students in 1975.49 The school has many problems due to lack of staff and lack of funding. The teachers are all volunteers, and there are only five of them. Funding comes from the tuition--which is only two dollars a quarter--and from contributions. The CCBA holds various types of fundraising activities for the school--dinners, rummage sales, etc. 
The school now includes two levels of instruction for children adult classes in Cantonese, Mandarin, and English; and a Chinese culture and dance class. The latter program was initiated in 1972 with the help of a grant from the National Endowment for the Humanities. 50 Another program in the Chinese community is the community newsletter, the Oregon Chinese News, which has a circulation of about eight hundred, and appears four times a year. It also has funding difficulties, and is supported by CCBA fund-raising activities.

There is also a recently-funded CETA project to collect Chinese oral history. Only one person has been hired so far for this project, which is still just getting started. The CCBA has had trouble finding people who both meet CEPA requirements and are the sort of people the elderly Chinese could talk to easily. One measure of the extent of interest among the Chinese in the community organizations is the number of people voting in the annual general elections of the CCBA. In December of 1977, an estimated two thousand ballots were distributed for these elections. POWER STRUCTURE OF THE CHINESE COMMUNITY

There are many different viewpoints in the Chinese community today; many ideologies; many attitudes towards being Chinese; and many strategies concerning the direction in which the Chinese community should go. It 
is the purpose of this section to explore some of these various ideas and factions, and determine the characteristics of the leadership of the Chinese community in Portland.

\section{Political Activism}

In general, the political experience of the Chinese in the United States has been one of accomodation rather than activism. But different groups within the Chinese population have radically different orientations in their attitudes toward the Chinese community.

Most of the Chinese we talked with, and especially those in leadership positions, showed no interest in political or social activism. Some of the younger Chinese, however, expressed favorable attitudes towards activism. One person said, "I think its a valid way of getting what you want...Playing the stereotype of sitting back and taking it is not going to work."

In Portland, one sees little political activity of any kind in the Chinese community; but in the large Chinatowns in California and in New York City, there has been a great deal of radical political activity. James Wong conducted a survey which showed that $40 \%$ of Chinese youth in San Francisco felt Mao Tse-tung to be the real leader of the Chinese people, while only $21 \%$ felt that Chiang Kai-shek was the real Chinese leader. 51 The older 
generation, on the other hand, has traditionally been highly supportive of the Kuomintang government.

There have been a profusion of radically oriented groups organized in these Chinatowns during the 19608 and 70s--politically-oriented youth gangs such as the Hwa Chings and the Leways; student groups such as the Inter-collegiate Chinese for Social Action, the Free University of Chinatown Kids, Unincorporated, and the Asian-American Political Alliances and radical groups such as the Red Guards and I Wor Kuen.

Many of the groups were influenced by the black power movement of the late $60 \mathrm{~s}$. As one writer saids

A yellow movement has been set into motion by the black power movement. Addressing itself to the unique problems of Asian Americans, this "yellow power" movement is relevent to the black power movement in that both are part of the Third World struggle to liberate all colored people. .52

We have seen that there have been radical and socialist organizations in the San Francisco Chinatom since the 1930s. But they have never succeeded in displacing the traditional, conservative leadership of the community (represented by the Six Companies, the tongs, etc.).

The success of this movement in organizing the Chinese community, and becoming a viable force in the leadership of the community, was extremely limited. There were some impressive accomplishments. Kuramoto 
says that at least fifteen Asian studies programs have been instituted in various Califormia universities. 53 In San Francisco, radicals were able to save the Intemational Hotel, a tenement which provided housing for many poor Chinese and Filipinos. 54 one group formed a Chinatown Cooperative Garment Factory in the basement of the hotel in an attempt to demonstrate that the control of the white business interests over the Chinese garment workers could be broken. 55 Also, in 1969 an Asian Community Center was organized in the San Francisco Chinatown, and attempted to deal with problems of employment, housing, medical care, etc. 56 so radical groups have had some success in providing services and leadership to Chinese communities; but their impact has not been very great.

In Portland, we have found no radical Chinese organizations although some of the younger Chinese are sympathetic to radical ideology. The Traditional Conservatiom of Chinese Leaderghip

The radicals have been vigorously opposed by the traditional Chinatown ruling elites, who have traditionally been politically conservative, anti-Communist, and supportive of the Nationalist Chinese.

We have seen that the Chinese community in Portland has historically been very much in support of the Nation- 
alist Chinese government-pilots were trained for service in World War II, fund-raising drives were held, and the Kuomintang branch in Portland was given space in the CCBA building. The $1950 \mathrm{~s}$ was the time of the most intense anti-Communism in the Chinese community. Americans were nervous about possible attempts by the Red Chinese to influence Chinese in America. F.B.I. Director J. Edgar Hoover expressed concern that many Chinatowns sheltered Communist agents. The memory of the internment of West Coast Japanese during World War II was still strong, and the McCarran-Walters Act made such actions legal in future national emergencies. The Chinese community thus felt a need to demonstrate its loyalty to America. An Anti-Communist League was founded in Portland by Bong Wai Chen in the early 1950s. 57

Today, the Chinese community leaders are still mostly conservative ideologically. But they refrain from any political activities or statements. Many of the people we interviewed expressly stated that they had no interest in political affairs.

Attitudes of Community Leadership Concerning the Chinese Community

The leaders of the Chinese community obviously owe their positions to the fact that they are dedicated to a continuation of the Chinese community and its organizations, values, and traditions. But there are many different 
attitudes among the Chinese leadership about their identity as Chinese.

Dean Ian has done a study of the attitudes of Chinese elites in San Francisco, and his classiflcation of the most common outlooks of these people seems to be very applicable to the leadership of the Portland community. Ian delineates three basic attitudes, accomodating, benevolent, and suspicious. 58

By "accomodating", Ian means that the person is in favor of total integration of Chinese into white society. Such an individual asserts that the Chinese are a model minority and have no problems. He denies that any form of discrimination against Chinese still exists.

We observed such attitudes in several of the Chinese leaders we interviewed. One man told us of the Chineses "They want to earn their right to be a citizen...We want to progress generation by generation." He asserted that demonstrating was not the way to earn rights; if one behaved well, he would be rewarded. He said Chinese are no longer stereotyped or discriminated against; they are middle-class, professional people who live like everyone else.

Lans description of the "benevolent" individual is one who is inter-racially tolerant. He is concerned with 
the problems of the Chinese, but accepts the American middle-class culture. His business associates are mainly American, but his friends are mostly Chinese. This is the most common sort of outlook we encountered in our interviews of Chinese leaders, in Portland. Lans description fits the orientation of one man who told us: "Therels no wide open doors for me to reach the top... But there's no closed doors like there were before." He is very active in working for the good of the Chinese community, and freely criticized Portland political leaders for their lack of sensitivity concerning the Chinese community. But he himself is very Americanized, fairly well-to-do, and is a partner in an engineering consulting firm.

The "suspicious" orientation is described by Ian as avowedly pro-Asian. Such an individual perceived a pattern of institutional racism in American society. and sees the "model minority" stereotype of Chinese as a white strategy in the racial struggle between whites and people of color. This is an activist, conflictoriented attitude towards the Chinese community. We found no representatives of this attitude among the leadership of the Portland community.

There are thus various attitudes present among the leadership of the Chinese community. People feel differently about their status as Chinese, and about the directions in which the Chinese community should go. 
Factionalism and Cooperation in the Portland Community

In general, however, the leadership of the Portland community has much in common. There is a basic agreement on goals, a consensus on the importance of retaining their heritage, and a similarity of personal characteristics-most of these leaders are male, middle-aged, upper-middle-class professionals.

Some people indicated to us that disagreements did exist-- "Not so much disagreement as a differing of opinion," said one woman. But the formal leadership. such as the members of the CCBA couneil, can generally reach a majority decision, which is then supported by all council members.

Thus, there is little factionalism among the community leaders; and as far as we have seen, generally there is support of the decisions of the leadership by the community as a whole.

THE PRESENT STATE OF CHINESE ORGANIZATIONS

At present, there are nineteen different Chinese organizations in Portland, all of which are constituent members of the CCBA (which constitutes a twentieth Chinese organization). The traditional organizations have declined in membership, influence, and in their level of activity, but continue to exist. The American-type organizations discussed in the last chapter continue to exist, and several new organizations based on American forms have 
groups (as we discussed earlier) seem to have died out. The Chinese churches have gained a great deal of importance in the Chinese community, and in addition been organized in recent years. Some cultural organizations continue to exist, although others, such as youth to the Baptist and Presbyterian churches, two new churches are now in existence.

The Chinese Consolidated Benevolent Association

The CCBA continues to be the coordinator of all community activities, and the CCBA president is by consensus regarded as the legitimate spokesman for the whole Chinese community. The actual degree of influence of the CCBA on the Chinese in Portland is open to a great deal of question.

Chia-in Chen writess

Who are they, the president, ex-president, and the ex-ex-president of the CCBA? Whom do they influence? I think they may have some influence on a very small number of poople. 59

One important question is: of the five to seven thousand Chinese in the Portland area, how many have any interest in these Chinese organizations? Because of the increasing integration of the Chinese into the broader society, and the large number of recent immigrants with few contacts with the established community, we believe that the percentage of Chinese with an interest in the Chinese community is probably not large: perhaps only a quarter or a third of the 
total community. In a survey by James Wons, conducted in San Francisco, only $35 \%$ of the respondents were interested in participating in an Asian organization. 60 We know that few people are really active in planning and organizing CCBA activities; one person estimated this number at about forty. But on the other hand, the Oregon Chinese News has a circulation of close to a thousand, and two thousand ballots were distributed for the last CCBA election.

Many of the functions of the CCBA have changed over the years. Several people we talked with emphasized that today the CCBA's functions are more in the area of social service than protective, as they once were. A former CCBA president said,

The activity today is different than it was before. The purpose is different: the function is different. It's more social-serving now than it was for specific causes than. At that time, it was more a defensive operation for protection against this, protection against that. Today were serving our Chinese community.

But the CCBA is limited in resources. The property that it and the district associations once owned in Chinatown has deteriorated. Fund-raising within the community does not raise all the money needed for desired programs. And the Chinese, as a small minority group, have difficulty getting any support through govermment or foundation funding.

We have mentioned in previous pages many of the current projects of the CCBA--the Chinese Information Service, the Oregon Chinese News, the Chinese Ianguage 
School, the program of English classes to new immigrants, the oral history project, and the work of the CCBA's Welfare Committee with the Chinese who are confined to nursing homes. All of these projects address a definite need in the community, but they are all extremely limited in the number of people they can serve, and the extent of services they can provide. The only support that has been received from outside the community has been in the form of CETA grants for two of these programs. In addition to the projects already mentioned, the CCBA has a scholarship fund for local Chinese students. In the early 1960s, Dr. Y.T. Iam donated generously to this fund, providing nearly ten thousand dollars. A yearly fund-raising drive is also conducted. But this fund is also small, and serves more as an incentive to worthy students than a real financial aid.

Some of the traditional activities of the CCBA continue, though in an attenuated form. In 1975. a one thousand dollar reward was offered in the case of a robbing and shooting at a Chinese social center, demonstrating continuation of protective functions. 61 The CCBA still maintains a cemetary fund, for burial of poor Chinese, though the fund contains less than four hundred dollars. The CCBA also maintains plots at the Lincoln Memorial Cemetary. 62 And, as we have previously noted, the CCBA continues to conduct celebrations of Chinese holidays. 
We mentioned the changes in the organization of the CCBA that occurred in the 1930s. In 1961, a new constitution was approved. 63 This constitution is included as Appendix $C$ of this paper. The current constitution provides for representation on the Executive Committee of each Chinese organization in Portland, and seventeen at large members, who are to be "elected from among thirty candidates, nominated by the Executive Committee and any Chinese business establishment." These at-large committeemen, as well as the president and vice-president, are elected annualiy by a general ballot in which any Chinese person in Oregon may participate. The CCBA is thus organized so as to represent all factions and groups in the Chinese community.

We have included much of the information we have on the history of the CCBA--its constitutional revisions, important activities, etc.--in Appendix B, "A Chronology of the Portland Chinese Community". Family and District Associations

The traditional-type Chinese organizations, modelled on institutions common to the China of the nineteenth century, still exist in Portland. But their role in the community has greatly diminished over the years. In other communities, they are evidently still influential. The Nees say of the San Francisco Chinatown: 
...prestige, accumulated resources, and continuing appeal to significant segments of the community have managed to sustain the influence of the clans as basic units in Chinatowns traditional institutional structure. 64

There are three family associations still existent in Portland today--the Lee association (Lee on Dong Benevolent Association); the Chin association (Gee How Oak Tan Society), and the Wong Family Association. of these, the wong Association is the largest. All of these groups theoretically include all chinese with the appropriate surname in their membership, but actually their active membership is today very small.

There is also one district association, the Hoy Yin District Association. Its active membership is also very omall. Today, these groups are primarily social--they hold annual picnics, support charitable causes, etc. In some cases, they may be helpful to people in finding jobs, or provide useful business contacts; but this is no longer their primary function. Their principle role in recent years has been to help retain the traditional Chinese customs in the face of the dissolution of the Chinese community. For instance, the last Chinese shrine, or joss house, in Portland, was still existent in the 1950s in the Chin Association building. 65 
Tongs

The four big tongs which have existed in Portland since the $1890 \mathrm{~s}$ still exist today. These are the Bing Kung-Bow Ieong Tong, the Suey Sing Tong, the Hip Sing Tong, and the Hop Sing Tong. Today, however, these organizations are no longer large and powerful. Their illegal activities ended long ago. These days, they are merely social clubs for old men. One man, a member of the Hop Sing Tong, said,

The tongs are nothing more than just a social organization... You join it because some friends of yours are in it, and that's about it. I joined it at the urging of my family... It's part of my own desire to keep up the Chinese in myself.

The membership of these tongs is fairly small, the Suey Sing Tong had a membership of about fifty a few years ago.66 They are also in poor shape financially. The tongs used to own much property in Chinatown, but now the remaining tong buildings are in very poor condition, and no resources are available for improving them.

The activities of the tongs are limited to social events such as parties, banquets, and celebrations of the Lunar New Year.

The Chinese-American Citizens Alliance

Some of the American-type Chinese organizations have also recently lost membership and influence. CACA, as we have seen, originally started as an organiza- 
tion of American-born Chinese at a time when most

Chinese in Portland were single, immigrant males. It later became involved in some civil rights activities, but the Portland chapter has always been primarily a social club. Now that most Chinese are American-born, and the Chinese have become more accepted by white Americans, the support group functions of CACA are no longer necessary.

Today, said one CACA member, "It really doesn't represent any significant number of people." The active membership of the Portland chapter is only twenty or thirty. It conducts several activities, such as an annual essay contest for high school students, organizing of youth activities, and charitable contributions. It also conducts social activities for its members. The national organization continues to do some lobbying in Congress, acts as an anti-defamation watchdog, and publishes a newsletter. It has recently tried to push for more funding of services for the chinese in America. 67

Although CACA is a social action organization, it is in many ways conservative. It is an old, established organization, and its membership consists of the older, middle-class, business and professional element of the Chinese community. At the 1975 biennial convention, which was held in Portland, CACA for the first time voted to 
allow women to become full members. 68

Professional Associations

We have mentioned the two Chinese professional associations in Portland--the Chinese Scientists and Engineers Association, and the Chinese Physicians and Dentists Association. These groups recognize the increasing number of professional people within both the established community, and in the recent immigrant population; and they provide a support group for such individuals.

There is also a Chinese Acupuncture Association. We know Iittle about this group, other than that it exists.

The Chinese Chamber of Commerce

The Chinese Chamber of Commerce is another recentlyformed organization. We are not sure exactly when it was founded, but the first mention of it in the oregon Chinese News comes in January of 1972.69

Our interviewees have said that the Chamber of Commerce is made up mostly of the owners of Chinese restaurants. Chinese restaurants are numerous in Portlandi one source says there are over fifty of them. 70 There are also several Chinese grocery stores, such as Fong Chong Grocery and Tuck Lung Grocery in the Burnside area.

An interesting thing about some of the older shops and restaurants is that they operate almost like a 
collective. The Fong Chong Grocery, at 301 Northwest Fourth, is an example of this phenomenon. It is an old style Chinese grocery, where we interviewed one of our respondents. There is always a group of Chinese men there working, waiting on customers, or just talking. The ownership of the store is elusive. An Oregonian reporter wrote: "Evidently it is owned by so many people, and so many nebulous people, that nobody knows." "l Few who work in such a shop are salaried, but everyone shares in the earnings. The Chinese Women's Club

The Chinese Women's Club, which was mentioned in Chapter VII, continues to exist, and is still a social and charitable organization. Its activities remain essentially the same as they were in the 1930s. We have mentioned their periodic visits to the elderly Chinese in nursing homes.

\section{Cultural Organizations}

The Yat Sing Music Club also continues to exist today. It is the only Chinese organization currently existing which is entirely for the purpose of conducting Chinese cultural activities. Beginning in 1956, it has annually given a performance of a Chinese opera.72 It has its office and practice room in the CCBA building. 
The Chinese Consulate

In the last chapter, we saw that the old Chinese Consulate in Portland was closed in 1950. In 1968, the Portland Chamber of Commerce proposed a re-opening of the Consulate.73 In 1972, Leland Chin, a highly respected community leader who had held many positions in Chinese organizations, was made Honorary Chinese Consul for the State of Oregon.74 In July of 1974, an official Consul, Henry C.Y. Wong, was appointed by Nationalist China, together with two Vice-Consuls. 75 There have been two other Consuls since that time, and the current Chinese Consul in Portland is Patrick P.C. Cheng, who arrived here in 1977.

The Consulate was re-opened for two reasons, apparently. First, trade between Portland and Taiwan has continued; secondly, increasing numbers of Chinese have been immigrating to Portland. The Consulate looks after the affairs of the immigrants from Taiwan, and cooperates closely with the CCBA.

\section{Chinese Churches}

There are currently four Chinese churches in Portland, with a total combined membership of around three hundred and fifty persons. The churches have become very important to the maintenance of a sense of 
community, for they are one of the few places where Chinese regularly get together and meet one another. Chia-lin Chen observes:

Ironically, the only opportunity for Chinese to gather together, not only in the Chinese community in the U.S. but in other places 36 including Taiwan, is in the Christian churches.76

The pastor of one of the churches concurred with this, and saids "If you want to contact the Chinese community, in my opinion, you contact the church."

The churches also provide some social services to the Chinese community. The minister of the Chinese Presbyterian Church explains his goals by saying: "We try to have gospel preaching and social service." As we saw in the last chapter, this church has historically provided various services to the Chinese community-English classes, a kindergarten, and an attempt at a community center.

Today, the church has about seventy active members, most of whom are immigrants from Hong Kong. The church holds English classes for about twenty students twice a week, and provides some services informally, such as interpreting, and information and referral. The church still has a social service center as a long range goal, but for the present such comprehensive services are financially unfeasible. The Chinese Baptist Church, which is the other old, established church in the 
community, does less in the way of provision of services. Its membership, which totals one hundred sixty persons; of whom about one hundred are active, includes more American-born Chinese than any of the other churches, though it also has many immigrant members. Up until six years ago, the Baptist Church had a Chinese language school, but now it has allowed this service to be taken over entirely by the CCBA.

There are also two newer Chinese churches in Portland. The Chinese Christian and Missionary Alliance Church was founded in 1974 from a Bible study group, which for a while had met in a garage. After the arrival of a pastor, it shared facilities with a white church for a while, and in June of 1976 moved into a used church building at Southeast 84th and Morrison. Its membership is only fifty-five or fifty-8ix, but nearly twice that many people come to the Sunday services and Sunday school. About $95 \%$ of the membership are young immigrants and Chinese foreign students; the average age of the membership is only 22.

This church also provides English Classes twice a week, at which the nighest attendance has been more than eighty people. Transportation is provided to bring people to these classes. Six classes on two levels are taught, and there is also a recently-started class in Chinese language and culture. 
The pastor of the Chinese Christian and Missionary

Alliance Church says of the English classes:

I know the community college provides that kind of classes, what they call English as a second language. But the Chinese folk dare not to attend because they know nothing, they're so:scared,

His attitude about these services is:

Our church emphasizes Bible teaching, but besides that we try to take a look around... In whatever area we can help we take the initiative:

The other church currently existing in Portland

is the Chinese Evangelical Church, sometimes called the Mandarin Church because many of its members are immigrants from Taiwan, and its services are given in English and Mandarin. Its membership is currently sixty-three persons. The church started in 1973 with six people who had met for three years as a Bible study group. The pastor is currently a student at Westerm Evangelical Seminary as well as minister to the church, so he has not had time to organize English classes or other services, but says he plans to do so when he is ordained.

These churches cooperate both with each other and with the CCBA. They all have representatives on the CCBA executive oommittee. Also, in February of 1977 a Fellowship of Portland Chinese Christian Churches was established by representatives of all four churches. This group coordinates activities between the churches 
and holds several joint services each year.

THE FUTURE OF THE CHINESE COMMUNITY IN PORTIAND

We have seen signs in the previous pages that the Chinese community in Portland is failing, assimilating, losing its traditions. At the same time, we could interpret what we have seen as not an end of the community, but an adaptation of the Chinese to new circumstances. There is evidence that retention of the traditional culture is still highly valued. The mere fact that there is still a sense of community among the Chinese today, although Chinatown is gone, is an indication that the community might continue. We can't say whether it will continue; and the Chinese we talked with have various opinions on the matter. We can say that after a history of over 125 years in Portland, the Chinese continue to have a sense of their heritage and their traditional values. Few other ethnic groups can say the same.

Community Goals

The immediate goals of the community leadership are to continue and increase the present activities and services in the community. But the community organizations have few resources with which to do this, and outside funding seems difficult to obtain. We discuss the issues involved in providing services to a small ethnic group in Chapter $X$. 
One project mentioned by nearly all Chinese leaders when asked about their goals was the New Chinatown. This idea has been discussed and planned for in the community for thirty-five years, but it seems questionable whether it will ever be realised. The idea essentially involves the renovation of the CCBA building, and the building of a Chinese business or tourist district in the Chinatown area in Northwest Portland.

As early as 1943, Chinese businessmen discussed the possibility of building a modern business center in Chinatown with the Portland Retail Trade Bureau. 77

It was not until 1961, however, that serious plans were proposed for such a center. Gene W. Rossman, director of the Portland Housing Authority, made a proposal for a Chinese center one block wide and three blocks long in the location of the Old Chinatown around Southwest Second Street. The center was to have Chinese shops and restaurants, underground parking, and a housing project for the elderly Chinese who still lived in Chinatown at that time. 78

The project was never implemented. It met with opposition from various sources. The Oregonian editorialized:

... any effort to revive the old Chinatown as a residential quarter for Portlanders of Chinese ancestry would be contrary to the desires of many of these people and to public policy which calis for integration, rather than segregation, of minority groups. 
When it was found that the housing in the project had to be open to all residents of the area if federal funding was to be received, the Chinese also became opposed to the plan. They did not want the Chinese senior citizens to have to live with the skid row elements.

But several months thereafter, the Chinese community leadership was enthusiastic about the possibility of building a Chinese business district. Leland Chin, the chairman of the committee assigned by the CCBA to the project, said in 1961, "This development will create tourist attractions, encourage better business, and create better relationships." 80

After a while, the enthusiasm died down. In 1964, Chin observed that "the promotion of the New Chinatown in Portland a couple of years ago seemed to have been forgotten." 81

The next year, however, a New Chinatown committee was again formed. ${ }^{82}$ Such a committee continues to exist today, but most Chinese leaders seem skeptical about the idea. One man said, "I think the idea is good. I think it's unsound, in that they didnt do any work."

The idea is still to revitalize the Chinatown area, but an additional goal is to build a new CCBA building, to replace the old one which has been used since 1910. The old building is now too small to house all the 
activities needed, and is in poor physical shape.

The problem with such ideas is to obtain funding. In addition, the city govermments plans for the Burnside area district are different from those of the Chinese community. The Oregonian quoted Bruce Wong, a Chinese community leader, as saying that,

If Portland's Chinatown isn't "saved"soon, all remnants may varmish, swept aside by the old Town development... Wong said he felt that in order to get enough support for new Chinese cultural center "we will need a new city administration"... He said the time is a long way off when federal funds will be used for a Chinese cultural project in much the same way as money has been uged for cultural efforts of blacks and Chicanos. 83

We also heard this opinion in our interviews. The city government was accused of going after the big business interests in development of the Burnside area, and ignoring the Chinese and Japanese people who had originally lived there.

Continuation of the Chinese Community

We encountered many opinions on the question of whether a sense of identity in the Chinese community would continue, and whether Chinese organizations would continue to exist.

Many people were pessimistic. Chia-lin Chen quoted one mans

We are fighting a losing battle...People scatter all around. The young people feel no need to learn the Chinese language and culture, and the parents cannot force their youngsters to do that. I an sure there will not be any Chinese community within twenty years' time.84 
Another person told us that he felt the community would deteriorate because "Chinese in Portland have it too good. They don't need each other."

But other people said they did not think the Chinese would ever become completely assimilated. One of our interviewees said he thought the organizations would continue! "Theyll be around for years to come." He didn't know about the attitudes of the third and fourth generation, "But the second generation will keep them going... There's enough community spirit." One woman told us: "We will always have a atrong Chinese community even if we live far apart." Others observed that the arrival of new immigrants meant that there would constantly be a need to be served by Chinese organizations. The president of the CCBA said of his organization:

I look for it to be viable, to render a service. Because there's constantly a new influx of Chinese immigrants coming from Hong Kong.

There are also differing opinions both in the Chinese community and in the Iiterature about whether or not the Chinese should assimilate. Rose Hum Lee makes a strong plea for assimilation:

...the conditions favoring total integration are at hand. The Chinese who waiver between partial or total integration should assess their emotional. psychological and social tendencies, and make their own adjustments to the realities of the times. The China which their parents or elders held up to them is no more. Those who are not backward. 85 should be helped to look forward, 
A few of our interviewees agreed with this, but most felt that, while an ability to blend into white American society was necessary, it was also very important to retain one's identification with Chinese society.

\section{SUMMARY}

At present, the living conditions of the Chinese in Portland put them under great pressure to assimilate. They are no longer subject to overt discrimination, although subtle forms of prejudice still exist. They no longer live in a segregated ghetto. Opportunities in professional and middle-class areas of employment have become available to them.

And yet, a strong system of community organizations still exists, which carries on the traditions of the Chinese culture. A desire to retain Chinese culture, language, and values continues to exist.

The Chinese organizations are still functional, because there remains a need for mutual support in the Chinese community. Various problems still exist-adjustment problems of new immigrants, problems with youth and with the elderly.

Despite continuous predictions over the years that the Chinese community would disintegrate, it has continued to exist in. Portland. 
In the next chapter, we will compare the experience of the Portland Chinese community to that of other Asian groups. 


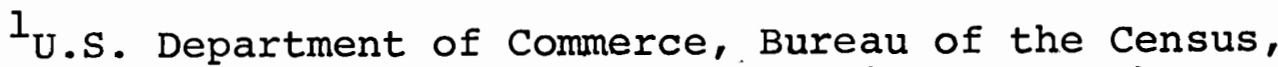
compilation of population of selected Asian groups by sex and census tract, (unpublished, 1970).

2 Rose Hum Lee, "The Decline of Chinatowns in the United States," American Journal of Sociology, LIV, (March $1949)$, p. 426 .

3 ibid., p. 430 .

4 ibid., p. 431.

5 ibid.; see also Melford S. Weiss, Valley City: A Chinese Community in America, (Cambridge, Mass.: Schenkman Publishing Co., 1974), p. 7 .

6 Bessie Ying Lee, "Perpetuation of Primary Group Patterns Among the Chinese in Portland, Oregon", (Masters thesis in Sociology, University of Oregon, 1938), p. 118.

${ }^{7}$ See also Paul Lum, "A Short History of the Portland CCBA", Oregon Chinese News, No. 46, (March/April 1975), pp. 6-7.

8 "Transaction Involving Oak street Building Drops Curtain on Area's Old Chinatown", Oregonian, August 20, 1964, p.33 c. 5-8; and "Nearly Last of City's Chinatown Buildings Will Be Razed for Downtown Parking Lot", Oregonian, July 15, 1965, S. 2 p. 2 c. 1-8.

${ }^{9}$ Asian-American Advisory Council to the Governor of the State of Washington, Report to the Governor on Discrimination Against Asians, (Seat tle: Asian-American Advisory Council, 1973), p. vi. See also, California Advisory Committee to the U.S. Commision on Civil Rights, Asian Americans and Pacific Peoples: A Case of Mistaken Identity, (Washington: U.S. Commission on Civil Rights, 1975).

${ }^{10}$ Roger Daniels and Harry H. L. Kitano, American Racism: Exploration of the Nature of Prejudice, (Englewood Cliffs, N.J.: Prentice-Hall, Inc., 1970), p. 80. See also Dean Lan, Prestige with Limitations: Realities of the Chinese American Elite, (San Francisco: $R$ and E Research Associates, 1976), p. vii.

${ }^{11}$ Lan, p. 49.

12 ibid., p. 12 .

13 Asian-American Advisory Council to the Governor of the State of Washington, pp. 20-74. 
${ }^{14}$ Victor G. and Brett De Bary Nee, Longtime Californ': A Documentary Study of An American Chinatown, (N.Y.: Pantheon Books, 1973), pp. 290-302.

${ }^{15}$ See Asian-American Advisory Council to the Governor of the State of Washington, pp. 75-78; and Lan, pp. 50-51:

${ }^{16}$ Urban Associates, Inc., A study of selected SocioEconomic Characteristics of Ethnic Minorites Based on the 1970 Census, Vol. IV, "HEW Regional Data", (Washington: Department of Health, Education, and Welfare, 1974), Table $\mathrm{X}-\mathrm{b}$, "Population Characteristics of Ethnic Minorities in Region X, 1970", pp. 40-41.

17 Chia-1in Chen, "Interviews with some Prominent Members of the Portland Chinese Community", (unpublished manuscript, Oregon Historical Society, 1973), p. 19.

${ }^{18}$ James I. Wong, Aspirations and Frustrations of the Chinese Youth in the san Francisco Bay Area: Aspersions Upon the Societal Scheme, (San Francisco: $\mathrm{R}$ and $\mathrm{E}$ Research Associates, 1977), p. 47 .

${ }^{19}$ H. Brett Melendy, The Oriental Americans, (N.Y.: Twayne Publishers, Inc., 1972), p. 82 .

${ }^{20}$ Nee, . pp. 258-259.

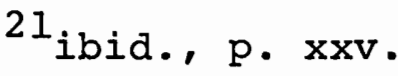

22 See Alex C. N. Leung, "Mental IIlness Among Chinese in the United States: Myth or Reality?", (Masters thesis in Psychology, Portland State University, 1976); and Stanley Sue and Derald S. Sue, "Chinese American Personality and Mental Health", from Roots: An Asian American Reader, Amy Tachiki, Eddie Wong, Franklin Odo, and Buck Wong, editors, (Los Angeles: UCLA Asian American Studies Center, 1971), p. 80.

$$
\begin{aligned}
& 23 \text { Nee, p. } 259 . \\
& 24 \text { Wong, p. } 65 .
\end{aligned}
$$

25 See Berkeley Rice, "The New Gangs of Chinatown", Psychology Today, $X$, (May 1977), Tom Wolfe, "The New Yellow Peril", Esquire, LXXIII, (December 1969); and Stanford M. Lyman, "Red Guard on Grant Avenue", Trans-action, VII, (April 1970).

${ }^{26}$ California Advisory Committee to the U.S. Commission on Civil Rights, pp. 5-6.

${ }^{27}$ Pei-ngor Chen, "The Chinese Community in Los Angeles", 
Social Casework, X, (December 1970), p. 592 .

28 ibid.

${ }^{29}$ California Advisory Committee to the U.S. Commission on Civil Rights, p. 11 .

${ }^{30}$ Nee, pp. $255-256$.

${ }^{31_{I}}$ Wor Kuen, Chinese-American Workers, Past and Present-An Anthology of Getting Together, (San Francisco: I Wor Kuen, Z1973?/), p. 77 .

${ }^{32}$ D. Y. Yuan, "Division of Labor Between Native-Born and Foreign-Born Chinese in the United States: A Study of Their Traditional Employments", Phylon, XXX, (Summer 1969), p. 164. See also Council on Social Work Education, Asian American Task Force, Asian American Task Force Report: Problems and Issues in Social Work Education, (N.Y.: CSWE, 1973), p. 7 .

33 "Chinese Physicians and Dentists Association Formed", Oregon Chinese News, No. 52 (Spring 1977).

${ }^{34}$ Kim Bik Au, "Economic Coping Patterns of Chinese Foreign Students in Portland State University", (Master of Social Work practicum, Portland State University, 1976), p. 24.

35 ibid., p. 14 .

36 ibid., p. 25.

37 Oregon Chinese News, No. 20, (June 1966).

${ }^{38}$ For an analysis of juvenile delinquency in these Chinatowns, see Wong, pp. 42-49; Lyman, op. cit.; and Rice, op. cit.

39 "Portland's Chinese Gang Problems Low Level", Oregonian, October 9, 1977, p. El c. 2-5.

$40_{\text {Wong, p. } 78 .}$

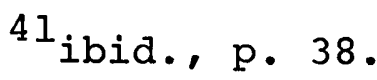

42 Nee, p. 384 .

43 Oregon Chinese News, No. 21, (October 1966).

44 Oregon Chinese News, No. 42, (December, 1973), p. 2.

${ }^{45}$ Linda Fong, "Occupational Prestige Among Chinese in 
the San Francisco Area", (Master of Social Work practicum, Portland State University, 1974), Table B, "Overview of Respondent Attitudes Concerning Chinese Practices", pp. 30-33.

${ }^{46}$ Wong, p. 65 .

${ }^{47}$ Vital Statistics Section, Oregon State Health Division, Oregon Public Health Statistics Report for Calendar Year 1976, (Portland: Oregon State Health Division, 1977), p. 82 .

${ }^{48}$ Wong, p. 63.

49 Oregon Chinese News, No. 46, (March/April 1975).

50 Lum, op. cit.

$5 I_{\text {Wong, p. }} 72$.

52 Amy Uyematsu, "The Emergence of Yellow Power in America", in Tachiki et. al., op. cit., p. 9.

53 Ford A. Kuramoto, "What Do Asians Want? An Examination of Issues in Social Work Education", Journal of Education for Social Work, VII, (Fall 1971), p. 12.

54 Nee, p. 390.

55 ibid., pp. 360-371.

${ }^{56}$ Rodan editorial staff, "Asian Community Center", in Tachiki et. al., op. cit., pp. 273-275.

57 James Doyle, "The Year of the Serpent", Portland Magazine, I, (Feb./March 1965), p. 12 .

${ }^{58}$ Lan, pp. $44-45$.

${ }^{59}$ Chia-lin Chen, private correspondence with the author, November 4, 1977.

${ }^{60}$ Wong, p. 81 .

${ }^{61}$ Oregon Chinese News, No. 46, (March/April 1975).

62 Oregon Chinese News, No. 52, (Spring 1977), p. 3.

63 Oregon Chinese News, No. 4, (September 1961).

${ }^{64}$ Nee, p. 183.

65 "Portland Chinatown Ignores Tourist Appeal; Idols 
Gathering Dust", Oregonian, Feb. 15, 1953, p. A8 c. 1-5. ${ }^{66}$ Chen, "Interviews...", p. 15.

67 "Chinese Feel Overlooked in Minority Funding," Oregonian, Aug. 7, 1975, p. B9 c. 4-8.

68 "Chinese-American Women Make Organizational Gains", Oregonian, Aug. 10, 1975, p. D2 c. 6-8.

69 Oregon Chinese News, No. 36 (January 1972).

${ }^{70}$ Chen, "Interviews...", p. 5.

${ }^{71}$ Ralph Friedman, "A Stroll Through old Chinatown", Oregonian, Dec. 25, 1966, Northwest Magazine, pp. 6-7ff.

72 Lum, op. cit.

73 Oregon Chinese News, No. 28 (November 1968).

74 Oregon Chinese News, No. 38, (August 1972).

${ }^{75}$ Oregon Chinese News, No. 44, (August 1974).

${ }^{76}$ Chia-lin Chen, private correspondence with the author, November 4, 1977.

77 "Chinese Center Discussed; Co-Operation Assured", Oregon Journal, Dec. 16,1943, p. 8 c. 6-7.

78 "New Chinatown Creation Urged; Plans Offered", Oregon Journal, March 23, 1961, Part 1, p. 16, c. 2-8.

79 "Revived Chinatown", editorial, Oregonian, March 9, 1961, p. 1 c. 1 .

${ }^{80}$ Oregon Chinese News, No. 4, (September 1961).

${ }^{81}$ Leland Chin, "President's Message", Oregon Chinese News, No. 13, (July 1964).

82 oregon Chinese News, No. 17, (July 1965).

83 Robert Owens, "Chinatown Preservation Sought", Oregonian, Feb. 22, 1976, p. C1 c. 1-2.

${ }^{84}$ Chen, "Interviews...", p. 14.

${ }^{85}$ Rose Hum Lee, The Chinese in the United states of America, (Hong Kong: Hong Kong University Press, 1960), p. 2. 
CHAPTER IX

DIFFERENCES IN THE EXPERIENCES OF

VARIOUS ASIAN GROUPS

In this chapter we wish to address the question of the extent to which our findings about the Chinese experience in Portland--history, current problems, degree of assimilation, and so forth--can be generalized. In many ways, the Portland Chinese community is unique and different from other Chinese communities in the United States. The Chinese people in general, as an ethnic group, are also different in important respects from other Asian groups.

Because of these considerations, the information recorded in this paper must be considered as illustrating the experience of one particular group only--the Portland Chinese community. The data here provides us with an understanding of this groupts experience which can help us understand the experiences of all Asians in America. But there are also factors-attitudes, conditions, and problems-mich are unique to this community.

This chapter is intended to point out both the similarities and the differences between the Portland Chinese community and other Asian communities.

THE PORTIAND CHINESE COMMUNITY COMPARED WITH OTHER CHINESE COMMUNITIES 
In previous chapters, we have already pointed out similarities and differences in the experience of the Portland Chinese and other Chinese communities on the West Coast and elsewhere. In this section, we wish to review these observations.

Population

We have seen that around the turn of the century, the Portland Chinatown was the second largest in the United States, next to San Francisco. After 1910, nowever, the population decreased rapidly. Today, it is increasing again, due to the new wave of immigration. But because of the large number of immigrants who have arrived in all areas of the United States since the 1970 census, it is impossible to know how the Portland Chinese community ranks in size with other Chinese communities. We presume that it is medium-sized--amaller than the communities in some cities in California and in New York City, but larger than most Chinese communities. The Portland community therefore does not have the same extent of problems as communities with large numbers of recently-arrived, unskilled immigrants (such as New York and San Francisco). But on the other hand, it does have some problems because of the influx of immigrants. It is a large enough community to support a wide range of organizations, activities, and services; but it is not large enough to have too many resources, or too many social problems. 


\section{Lack of Hostility}

We have seen that Portland had a lesser level of anti-Chinese hostility during the nineteenth century than most West Coast towns. As Chia-lin Chen wrote: "Oregon might be generally looked at as a refuge for the suffering Chinese:" 1

The Chinese miners originally came to Oregon in the $1850 \mathrm{~s}$ and 60 s to get away from the hostility they experienced in California. During the anti-Chinese riots of the 1880s, Portland took in Chinese expelled from towns in outlying areas, and even from some towns in Washington. While Portland had its own period of anti-Chinese agitation during this time, it was generally milder than what other cities had experienced; no one was killed, and the Chinese were not expelled.

This comparative lack of hostility had an effect on the development of the community. In the first half of this century, the male-female ratio became equalized much more quickly in Portland than in other areas. This allowed for a more rapid development of a family life, and a larger American-born population.

Also, the Portland Chinese began to move into white neighborhoods in Portland much earlier than was possible elsewhere. By the late 1940s, there was hardly any Chinatown left in Portland. 
Portland as an Urban Community

The fact that Portland is an urban community makes the experience of the Chinese here different than that of the Chinese in rural areas. In Chapter $V$, we compared the different types of employment in which rural and urban Chinese were engaged in the nineteenth century; but it should be noted that there were large numbers of Chinese engaged in migrant farming and other rural pursuits up until recent times. There are still many Chinese living in rural areas in Oregon, although as of 1970. 51.1\% of the Chinese population in this state lived in Portland.

The conditions of life for the Chinese in rural areas can be assumed to be very different from the conditions we described in Portland. Present Status of the Portland Chinese

We emphasized in Chapter VIII that Portland, although it has no Chinatown, does have a coherent Chinese community. This makes the Portland community practically unique, as far as we know.

The fact that a city with as large a Chinese community as Portland has no Chinatown is also to our knowledge u\$usual.

It is also our impression, although we have no statistics, that the Portland Chinese community has a 
higher percentage of professionals and businessmen, both within the established community and among the recent immigrants, than other communities of comparable size.

There is also apparently a smaller percentage of recent immigrants in the Pacific Northwest than in other areas of the United States. 2

THE EXPERIENCE OF OTHER ASIAN GROUPS

There is a tendency among white Americans to think of all Asian groups as alike--having the same attitudes, the same culture, the same problems. This is not true. A11 Asian cultures are different; and different Asian populations in the United States are also different.

We wish to look at some of the Asian groups, briefly outlining their experiences in America, and comparing this experience to that of the Chinese.

\section{The Japanese}

The Japanese form the largest Asian ethnic group in the United States, with the Chinese second largest. In many ways, their experience in America has been similar to that of the Chinese, but the two cultures are very different.

The immigration of Japanese to America began later than Chinese immigration, and followed a somewhat different pattern. As Daniels and Kitano observe, "Japanese immigration...adhered much more closely to the patterns created by immigrants from Europe." 3 
Like the Chinese, the Japanese immigrants were primarily male farmers, motivated by population pressure, rapid social change, and desire for advancement to seek a Iife overseas. 4 But the status of farmers in Japan was higher than that of farmers in China, and living conditions were much better than those in Southern China. The Japanese were thus wealthier, and of a higher social class, than the Chinese immigrants. Kitano says: "... in Japanese terms, these immigrants represented an educated, middle-class population." 5

It was not until 1885 that immigration was made legal in Japan, so it was not until this year, three years after the passage of the first Chinese exclusion law, that large numbers of Japanese immigrants began to arrive in America. 6

The employment of recent arrivals was similar to that of the Chinese immigrants. They worked in canneries, on the railroads, in lumber mills, and as house cleaners.? Many Japanese, however, were able to enter into independent businesses soon after their arrival. The most common such occupation was truck gardening. Melendy says that "Few Chinese became independent farmers, but the Japanese moved quickly to a status of independence." 8 By 1905, 35\% of the Japanese in Oregon were independent farmers. 9 Japanese farmers dominated berry farming and truck gardening in East Multnomah County in the early 19008.10 
The unions were as opposed to the Japanese in the early 1900 s as they had been to the Chinese in the 1880s and 90s. The United Mine Workers in Denver accepted Japanese as members in 1907, but most unions excluded them. Iike the Chinese, however, the Japanese formed their own unions. 11

Living conditions for Japanese, however, were much more favorable than for Chinese. In many towns along the West Coast there were Japanese ghettos-- "Little Tokyos"--but because so many Japanese worked as farmers, these ghettos were less common and smaller than the Chinatowns. 12

More importantly, however, the Japanese did not remain bachelors as the Chinese had; they were able to bring wives into this country through the "picture bride" system, in which a bride was selected from a photograph, and brought to America. ${ }^{13}$ Melendy says:

The first Japanese immigrants, like the Chinese and some European immigrants, were mostly single males. When the picture brides arrived, the Japanese did what most Chinese neyer could--they began to lead normal family lives.

The Japanese were subject to a great deal of hostility, but it never reached the level of violence reached against the Chinese. The same sort of racist arguments were brought forth against the Japanese as had served in the anti-Chinese agitation. Again, it appears that the root of the hostility can be found in a perceived competition 
of Japanese with whites for jobs and opportunities. One California newspaper writer wrote in 1910 .

Now the Jap is a wily an crafty individual--more so than the Chink,....they try to buy in the neighborhoods where there are nothing but white folks.15

In Oregon, the areas where the Japanese farmers were the most prominent and most competitive were the areas of the most anti-Japanese hostility. The Hood River Valley was one such area. An Anti-Alien Ieague aimed against the Japanese was organized there in 1919.16 When Japanese tried to buy farm land in Crook County in 1920, the farmers organized and kept them out. 17 In 1925, the Japanese were expelled from Toledo, oregon. 18

Anti-Japanese legislation was also passed in all the West Coast states and by the federal government around this time. The Japanese, like the Chinese, were not allowed to become naturalized citizens in the United States. We mentioned in Chapter IV the attempt to exclude Japanese students from the public schools in California in 1906, which was eventually given up at the urging of the United States government.

But because of the anti-Japanese hostility in the West, the federal government in 1907 pressured Japan to voluntarily restrict immigration. These proposals resulted in the "Gentlemerls Agreement", which allowed for exclusion of Japanese laborers from the United States. 19 
In 1913, Califormia passed an Alien Land Law, preventing Japanese from owning land. In 1923, after several unsuccessful efforts, Oregon also passed a law excluding Japanese and most other Asians. 21

The most serious action taken against the Japanese in America, however, was their intermment during World War II. On February 13, 1942, President Roosevelt signed Executive Order No. 9066, which allowed for the removal of all Japanese from the West Coast. Over 112,000 Japanese were confined in ten "Relocation Centers", which were in actuality concentration camps. Few, if any, of these people were in any way disloyal to the United States. Seventy thousand of them were native-born American citizens. Property of these people was supposed to have been held for them, but much of it was actually confiscated or destroyed. After the war, the Japanese filed claims for over 130 million dollars in losses, but were only reimbursed thirteen million dollars. 22 The Japanese, like the Chinese, formed many community organizations, but these groups were never as important in maintaining culture or providing mutual support as were the Chinese groups.

The Japanese Associations were the first such groups to be formed. Michinari Fujita describes them as "a group of social, political, economical, and educational 
organizations extending throughout the United States, but chiefly on the Pacific Coast." 23 These organizations are somewhat analogous in function to the Chinese Six Companies, but were not as all-encompassing or influential. One of the four "central associations" (i.e. regional headquarters) was in Portland.

The most important organization for American-borm Japanese is the Japanese-American Citizens League (JACL), which is very similar in type of membership (second generation), and activities (civil rights and social) to CACA. The names of the two groups are even similar. JACL was founded in 1930 in Seattle. 24

Japanese language schools were successful in some areas of the country, but never really got started in Portland. 25

Missions also operated among the Japanese, conducting the same activities--teaching English, "Christianizing", etc.--as had been the case with the Chinese. 26

Thus, there are many similarities between the experiences of the Japanese and the Chinese in America. There are, however, significant differences. As pointed out in Chapter IV, the Japanese government was much more successful in protecting the rights of its overseas citizens than had been the Chinese government. Also, the Japanese were not confined to ghettos to the same extent as the Chinese, got into independent business 
sooner, and generally have become more assimilated and Americanized than the Chinese.

\section{Filipinos}

The Filipinos also form a large Asian group in the American population. The key factor about the Filipinos today, however, is that they are still for the most part restricted to menial and "preindustrial" areas of employment, such as migrant farming.

An important consideration about their immigration is that they came from an actual colony--not a pseudocolony, such as Chinese; or a free and powerful nation, like Japan. The Phillipines had been under control of Spain for over three hundred years (from 1571), and then passed into the hands of the United States in 1898. While the Chinese in America could draw strength and support from their traditional culture and values, the Filipinos had been under Western control for so long that by the time they began to immigrate to America, their traditional culture had virtually ceased to exist. Even their native language had been replaced by Pilipino, a sort of pidgin Spanish.

Juanita Tamayo Lott comments on effect of these circumstances on the Filipino immigrants:

The Pillipino community in the United States has been and continues to be shaped by the influences of a mentality that had its origins in the

Phillipines--the colonial mentality. This mentality is carried over with each immigrant and is gustained in the environment of intemal colonialism. 2 ? 
The Filipinos began to immigrate to America in the 1920s. By 1930, there were 45,000 Filipinos in the mainland United States, 30,000 of whom were in California. They followed the pattern of immigration we have previousiy seen--they came as single men, and they worked as migrant agricultural laborers. When they did live in the cities, they were employed in menial jobs. 28

Their numbers were not large enough to threaten white laborers, but they became the victims of hostility and prejudice because they attempted to go out with white women. Dance halls for Filipinos had sprung up in California, charging ten cents a minute and staffed by white hostesses. Anti-Filipino agitators condemned these establishments as hotbeds of sin. The anti-miscegenation statute in Califormia, which had included blacks, Chinese, and Japanese, was quickly amended to include Filipinos. 29

It was difficult to exclude Filipinos from America, because they were native-borm residents of U.S. territory. A 1925 law made them ineligible for citizenship unless they served in the Navy for three years. 30 Exclusion laws were proposed, but not passed, in 1929 and 1930. But in 1935, a law was passed allowing for independence of the Phillipines by 1945. The independence was delayed, but a quota on immigration of fifty per year was immediately imposed. 31 From this time until the relax- 
ation of the immigration laws in the 1960s, there was very iittle Filipino immigration.

The Filipinos in America today still occupy a very low status. Daniels and Kitano say that, "In short, an unhappy Filipino stay in California can be summed up in an aphorism: 'last imported, least upwardly mobile. 132 Most Filipinos are still employed in unskilled labor. 33 Koreans

Since the early 1900s, there has always been a small Korean population in the United States, but in recent years this population has grown dramatically with the arrival of thousands of new immigrants. In the Portland metropolitan area, for instance, there were only 435 Koreans in 1970,34 but today the population is estimated at around five thousand.

Korea is a small country between two great powers-China and Japan--and has been heavily influenced by both nations throughout its history. But Korea is still racially, linguistically, and culturally very distinct from China and Japan.

The first Korean immigrants to come to the United States began arriving in the 1870 s and 1880s. The early immigrants included both students and laborers. But there were never large numbers of immigrants. As of 1930, the total Korean population in the United States was only 1860, 1097 of whom lived in California. 35 In 1923, there were only about forty Koreans in Oregon. 36 
When Japan took over control of Korea in 1910, Koreans became subject to the same immigration restrictions as the Japanese; Korean passports were no longer recognized. But the Japanese did not devote as much effort to looking after the interests of Koreans in America as they did their own nationals. 37

The occupations of the Koreans were similar to those of other Asian groups, but the focus of their organizations was very different. First, most of the Korean immigrants were Christian. A's we have seen, the Chinese churches have recently become centers of the Chinese community in Portland; but for the Koreans in America, this was always the case. 38

Secondly, these immigrants were dedicated to Korean nationalism and the overthrow of Japanese colonialism. Bok-Lim Kim says:

...all of their energy, talents, and attention were focused on overthrowing the Japanese rule and regain-

Their organizations reflect this fact. One Korean nationalist group was the Taohan Kukminhae (당 aly), Whish translates as Korean National Association. This group was formed in 1909 as a congress of all Korean organizations. It was in this respect similar in organization to the CCBA. In 1910, however, it began a program of political activism against the Japanese, and essentially took on the form of a Korean government-in-exile. 40 In fact, one of the organizers of the Taehan Kukminhae, Syngman Rhee, 
became President of the Korean Provisional Government in Shanghai in 1919, and the first President of South Korea in 1948.41

Today, the number of Koreans in America has increased dramatically. Kim says that an increase of 1300 percent occurred between 1965 and 1974.42

Figures from the U.S. Immigration Service in Portland show that the number of Koreans with permanent residency status increased $130 \%$ between 1972 and 1976.

Thus, the great majority of Koreans in the United States are recent immigrants. Many of them are educated or professional people, fairly well prepared for life in America. But there are still problems in the Korean community similar to those we observed among the recent Chinese immigrants. Many well-educated Koreans are forced to take low status jobs due to language, cultural barriers, and lack of professional certificates recognized in America. 43 There is also a need for services to Korean senior citizens.

The Korean community, having existed only a short time, is not very well organized, and has few resources. In Portland, there are four Korean churches, a Korean Society of Oregon, and a Korean-American Senior Citizens' Society. The latter group provides services to elderly Koreans, but has very few resources and cannot provide all the services needed. 
Indochinese

Indochinese groups in America--Vietnamese, Laotian, Thai, and Cambodian--are also made up primarily of recent immigrants. The 130,000 Vietnamese brought to this country after the end of the Vietnam War constitutes the largest such group.

These immigrants and refugees contend with the same difficulties of employment, language, etc., as other Asian immigrants. But the U.S. Congress did provide some funding for services to the Vietnamese immigrants. Service centers were established in many American cities. An Indochinese Cultural and Service Center in Portland, at 1607 Northeast 4lst, provides medical, job counseling. language training, and other services to Indochinese in the Portland area. The federal program of assistance to these groups was contracted to several church-affiliated welfare organizations, and these groups operate the center. Recently, however, federal funding was cut off, and the center is operating now with extremely limited resources.

Gregory. Ying-nien Tsang criticizes the government's handling of the resettlement of the Indochinese refugees by saying that programs were initiated without adequate planning, and few service centers have any Indochinese staff members. 44

Pacisic Islanders

Pacific island peoples, like the Filipinos, have a long history of colonial domination by the United States 
and other Western nations. The traditional culture ois many of these islands has been totally destroyed by the colonialists.

Increasing numbers of immigrants from islands such as Guam and Samoa have recently been arriving in the United States. They have an overly-idealized picture of their chances in America; and have problems finding adequate: housing and employment. 45

COMMON INTERESTS AND EFFORTS OF ASIAN GROUPS

It is evident that there are many similarities in the historical experiences of the various Asian ethnic populations in America. But each group has its own outlook, its own concerns, and its own heritage, often very different from that of other Asian groups. We can say that the patterns of white racism imposed on all Asian people have been the same; but the people themselves are different.

Because Asian people have similar experiences in America and similar problems, and because individual groups of Asians are rather small; there would appear to be definite advantages to coalition-forming between various Asian populations. Ford Kuramoto is an advocate of this strategy; he argues that unity is necessary to obtain the support of government and private funding agencies for Asian programs. 46 
But there are many difficulties with this idea. Asian-Americans, if they identify with their heritage at all, will identify with their own particular ethnic or national group, not with all Asian groups. Also, the languages of these groups are different. If, for instance, an Asian coalition organized a multi-ethnic multi-service center, there would be a need for bi-lingual staff in not just one language, but for several languages. Also, decisions as to which group would control such a center may be a problem.

In addition, all Asian populations do not necessarily get along with each other, even if one assumes that they have the same basic interests. Koreans, for instance, generally dislike the Japanese, because of a stereotype of Japanese built up over the many years of Japanese oppression in Korea.

The Council on Social Work Education's Asian American Task Force concludes:

An obvious danger is to look upon all Asian American communities as being the same...

The various Asian communities are not only different in culture and language but also different in terms of number, group cohesiveness, stability, level of development and achievement in education, professional manpower, economic and political atatus, etc., within the larger American society.4?

Examples of Inter-Asian Cooperation

There are, however, indications that Asian population groups are beginning to form coalitions. 
The largest such organization is the Pacific-Asian Coalition (PAC), formed in 1972. It grew out of contacts made and discussions held during a National Asian American Mental Health Conference held in San Francisco in that year. PAC is a national coalition of Asian organizations, organized into nine geographical regions, and works to develop services, conduct research, and train workers to meet the needs of Asian communities. ${ }^{48}$ There is also a Council of Oriental Organizations in Los Angeles, 49 and several coalitions of radical Asian groups.

\section{Inter-Asian Cooperation in Portland}

There have been several attempts at cooperation and coalition-forming between Asian groups in Portland. None of these efforts, however, have been successful.

The Chinese leaders we interviewed seemed to have generally negative attitudes about such cooperation. The CCBA president told us that there was at one time talk of an Asian Society, but his attitude is: "I'm just content to take care of Chinese because I am Chinese." The CCBA did send a representative to a Northwest Asian Conference held in Seattle in 1974.50 There was also an attempt in 1972 to set up a nursing home with the Japanese and Filipino communities, but this plan did not get far. One person told us, "Everybody has a different idea." 
One of the leaders of the Chinese community proposed in 1975 that Chinese families sponsor some of the vietnamese refugees, 51 but this idea was also abandoned.

Thus, regardless of the advantages apparent in unity among different Asian groups, it seems unlikely that such coalitions will become a significant force in the Portland community.

An article by Kushida et. al. points out that, These two unique factors--the characterization as the "model minority" with the absence of concomitant rewards, and the diverse, multiethnic character of the group--place special demands on programs designed to meet the needs of Asian Americans. 52

In the next chapter we will examine the options for social services to the Chinese community, and make a case for community-designed services, operated through traditional community organizations. 
CHAPTER IX: FOOTNOTES

${ }^{1}$ Chia-lin Chen, "A Gold Dream in the Blue Mountains; A Study of the Chinese Immigrants in the John Day Area, Oregon, 1870-1910", (Masters thesis in History, Portland State University, 1972), p. 36 .

${ }^{2}$ Lemuel F. Ignacio, "The Pacific-Asian Coalition: Origin, Structure, and Program", Social Casework, LVII, (March 1976), p. 133.

${ }^{3}$ Roger Daniels and Harry H. I. Kitano, American Racism: Exploration of the Nature of Prejudice, (Englewood Cliffs, N.J.: Prentice-Ha1, Inc., 1969), p. 10.

${ }^{4}$ H. Brett Melendy, The Oriental Americans, (N.Y.: Twayne Publishers, Inc., 1972), pp. 89-90.

${ }^{5}$ Harry H. I. Kitano, Japanese-Americans: The Evolution of a Sub-Culture, (Englewood Cliffs, N.J.: Prentice-Hall, Inc., 1969), p. 10 .

6 ibid., p. 12 .

7 Melendy, pp. 140-141.

$8_{\text {ibid., p. } 133 .}$

${ }^{9}$ Marjorie R. Stearns, The History of the Japanese People in Oregon, (San Francisco: R and E Research Associates, 1974; from a thesi written in 1937), p. 2 .

$10_{\text {ibid., p. } 3 .}$

${ }^{11}$ Melendy, pp. 141-143.

$12 \mathrm{Jim}$ H. Matsuoka, "Iittle Tokyo; Searching the Past and Analyzing the Future", in Roots: An Asian American Reader, Amy Tachiki, Eddie Wong, Franklin Odo, and Buck Wong, editors, (Los Angeles: UCLA Asian American Studies Center, 1971), pp. $322-324$.

13 Stearns, p. 2 .

14 Melendy, p. 146.

${ }^{15}$ Kitano, p. 26.

${ }^{16}$ Stearns, p. 11 .

17 ibid., p. 15. 
$18_{\text {ibid., pp. } 19-20 .}$

${ }^{19}$ Melendy, p. 111 .

${ }^{20}$ Stearns, pp. 22 and 79.

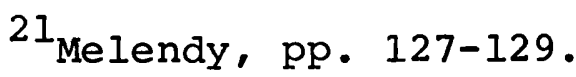

22 ibid., pp. 156-164.

23 Michinari Fujita, "The Japanese Associations in America", Sociology and Social Research, XIII, (1929), p. 211.

${ }^{24}$ Melendy, p. 148.

${ }^{25}$ Stearns, p. 93.

26 ibid., pp. 95-96.

27 Juanita Tamayo Lott, "Migration of a Mentality: The Pilipino Community", Social Casework, LVII, (March 1976), p. 166 .

28 Daniels and Kitano, pp. 66-67; and H. Brett Melendy, "Filipinos in the United States", in The Asian American: The Historical Experience, Norris Hundley, Jr., editor, (Santa Barbara: Clio Press, Inc., 1976), pp. 104-11l.

29 Daniels and Kitano, pp. 67-68.

${ }^{30}$ Violet Rabaya, "Filipino Immigration: The Creation of a New Social Problem", in Tachiki et. al., op. cit., p. 190.

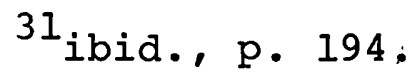

32 Daniels and Kitano, p. 68.

33 Melendy, "Filipinos in the United States", p. 1ll; and Lott, op. cit.

${ }^{34}$ U.S. Department of Commerce, Bureau of the Census, compilation of population of selected Asian groups by sex and census tract, (unpublished, 1970).

${ }^{35}$ Helen L. Givens, The Korean Community in Los Angeles, (San Francisco: $R$ and $E$ Research Associates, 1974; from a thesis written in 1939), pp. 16-17.

${ }^{36}$ Fred Lockley, "Impressions and Observations of the Journal Man", Oregon Journal, November 5, 1923, p. 4 c. 6-7.

${ }^{37}$ Lee and Chang-su Houchins, "The Korean Experience in 
America, 1903-1924", in Hundley, op. cit., pp. 130-132.

38 ibid., p. 129; and Bok-Lim C. Kim, "An Appraisal of Korean Immigrant Service Needs", Social Casework, LVII, (March, 1976), p. 173.

39 Kim, p. 14 .

40 Houchins, pp. 140-147.

$4 I_{\text {ibid. , p. } 148 .}$

$42_{\text {Kim, p. } 139 .}$

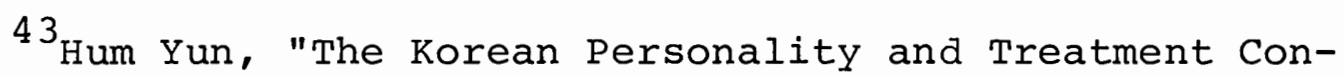
siderations", Social Casework, LVII, (March 1976), p. 173.

44 Gregory Ying-nien Tsang, "Editorial Notes", Social Casework, LVII, (March 1976), p. 220.

45 Faye Untalon Munoz, "Pacific Islanders-- A Perplexed, Neglected Minority", Social Casework, LVII, (March 1976), pp. 179-184.

46 Ford A. Kuramoto, "Lessons Learned in the Federal Funding Game", Social Casework, LVII, (March 1976), p. 213.

${ }^{47}$ Council on Social Work Education, Asian American Task Force, Asian American Task Force Report: Problems and Issues in Social Work Education, (N.Y.: CSWE, 1973), pp. 5 and 6 .

${ }^{48}$ Ignacio, op. cit.

${ }^{49}$ Daniels and Kitano, p. 115.

50 Oregon Chinese News, No. 44, (August 1974).

51 Oregon Chinese News, No. 48, (Dec. 1975/Jan. 1976).

52 Arlene Hori Kushida, Marilyn Montenegro, Paul Chikahisa, and Royal F. Morales, "A Training Program for Asian and Pacific Islander Americans", Social Casework, LVII, (March 1976), p. 186. 
CHAPTER X

SOCIAL SERVICES FOR ASIAN COMMUNITIES

Are social services designed for specific ethnic minority groups necessary, or even justifiable? The prevailing American tradition calls for a "Melting Pot", in which immigrant groups are supposedly able to mix with the predominant American society, eventually taking on its culture and values. In such a scheme, immigrant groups would be encouraged to give up their distinct characteristics and conform to the way of life of the white middle-class.

To proponents of the "Melting Pot", social services designed for a particular ethnic group, perhaps involving bilingual workers, culture-specific methods of practice, etc., would seem undesirable; for they might merely serve to delay the eventual, hoped-for assimilation in the main-stream. Programs specifically intended to help maintain the traditional culture--such as the Chinese Language School--would be seen as completely unwarranted. Racial minorities, however, have rarely been given the same opportunities in America as the white middle class, and can thus hardly be expected to take on its life-style immediately and without difficulty. Besides, even if everybody could live like white Americans, not 
everybody wants to. Popular American culture is not universally attractive, and much can be said for many of the values and ways of life inherent in other cultures.

There are also some unique needs and problems common to ethnic minorities--and especially to immigrant groups -which are not present in the white society; and are not addressed by the traditional white-oriented social. service system. Language is one such problem. Disability due to the effects of white racism is another. We therefore wish to argue that services designed for specific ethnic groups are necessary, valuable, and should be supported more strongly by funding agencies. The first consideration in our argument is the fact that the problems of Asians have been ignored by traditional social services, primarily because they are said (mistakenly) to have no problems. THE MYTH OF THE "MODEL MINORITY"

White Americans have been told that Asians constitute a "model minority" - they don't demonstrate, they don't live in slums, they don't go on welfare, and they are increasingly entering professional and white collar occupations. Ford Kuramoto observes that:

It seems apparent that Asians suffer the disadvantage of being either overly recognized in a stereotyped, stigmatized way, or inadequately recognized as a distinct ethnic group in the population... Part of the Asian problem is that the majority of society believes that Asians do not have problems and in some cases, thaf Asians do not even constitute a minority group. 
In addition to this stereotype, there is the idea that even if Asians do have problems, they "take care of their own", and do not need any help from outsiders. In fact, as we have seen, the Chinese do place a high value on "taking care of their own", but their resources are very limited, and although they would like to, they cannot take care of everybody. Therefore, as Kalish and Yủen state,

The common assumptions that Asian-Americans "take care of their own", or respect the elderly, or nrarely become social problems", are gross oversimplifications with very limited applicability. 2

The Nees quote a teenaged gang member in the San Francisco Chinatown:

But what they read and what they see on TV about Chinatown, you know, its a clean place where everybody's happy, and there's no trouble. And that means a lot of people are getting screwed up down here and don't receive no help. 3

We contacted several social service agencies in the Portland area, and asked about their services to Chinese clients. While our survey was not in any way exhaustive--only a few agencies were contacted--it is interesting that all the people we talked to told us that the Chinese needed no special services, because they take care of their own. Even those caseworkers who had clients who were destitute, elderly Chinese living in the Burnside area seemed to accept this idea.

There are many reasons why a casual observer would come to this belief. Some of this misunderstanding is due 
to cultural characteristics of the Chinese people; and some also comes from white stereotyping of the Chinese. As Peingor Chen writes:

Two significant factors contribute to the misconceptions about the Chinese population in America: (1) The general publids tendency to stereotype ethnic groups and (2) the Chinese peoplet 4 tendency to hide the darker side of their culture.

Derald and Stanley Sue further explain:

Their traditional nonthreatening stance and the publicts lack of knowledge about Chinese people have masked their problems of poverty, unemployment, and juvenile delinquency... The Chinese-Americans'strong emphasis on educational achievement, their custom of handling problems within the family, and their limited use of mental health facilities have reinforced this misconception.5

Effects of Such Stereotypes on the Struggle for Racial Equality

Unfortunately, such stereotyping has had an adverse effect on the struggle of all people of color for advancement in American society. Whether through conscious design or simple ignorance, the myth that a model minority exists has been used by whites as an argument against the demands of militant minority groups. Dean Lan says that:

...it represents an attempt to reaffirm the belief that any group regardless of race, creed, or color, can succeed in a democratic society--provided one works hard enough. The implicit assumption underlying this statement is that lack of success is due to and caused by intrinsic factors (racial inferiority, incompatible value systems, gtc.), rather than the racist nature of society. 6

Kuramoto puts the matter even more strongly:

Unfortunately, the Asian is currently a very important "pawn" in the racist strategy that is on-going in the 
United States today. Racism in America often seeks to legitimate itself, however unsuccessfully, by holding out the Asian as proof that democracy and equality are alive and well in America and thereby denying the existence of social problems. Many Asians feel that they occupy the status of "house nigger" in the hierarchy of racism in America.?

\section{Effects on Funding for Asian Programs}

The model minority myth also results in a reluctance on the part of funding agencies to support Asian programs; after all, if they dont have any problems, they don't need any support. A 1966 article in the U.S. News and World Report supports such reasoning:

At a time when it is being proposed that hundreds of billions be spent to uplift Negroes and other minorities, the nations 300,000 Chinese-Americans are moving ahead on their own--with no help from anyone else.8

Many Chinese resent the fact that they have not received their share of minority funding. One San Francisco Chinatown youth says, "We should stand up and fight back like the blacks... if there's no threats or riots or anything the federal government isn't going to help you at all." 9 And in 1975 Albert Gee, the national president of CACA, stated that, "The biggest problem facing Chinese-Americans is making federal and local funding sources aware of the problems and needs of Chinese minority communities." 10

In Portland, several Asian groups have drawn up proposals for various types of programs. But with the 
exception of a few CETA grants, no support for such programs has been forthcoming.

Thus, the Chinese and some other Asian groups have played the game according to the white rules--they haven't caused any trouble, but have persistently studied, worked hard, and struggled within the system for advancement. In return, they have had their problems ignored by the white social service establishment.

SPECIAI NEEDS OF ASIAN GROUPS

In Chapters VIII and IX, we discussed some of the problems of Asian minority groups. Some of these problems are shared with the entire American society (such as the loneliness and social isolation of the elderly). others, occurring primarily in the large Chinatowns, are typical of many big city ghettos-black, Chicano, Puerto Rican, as well as Asian. Such problems include poverty, juvenile delinquency, unemployment and exploitation of labor, poor housing conditions, etc. There are also problems that are unique to Asian communities, or occur more frequently in Asian communities. Culture-specific Problems

Knowledge of English among immigrants is an example of such culture-specific problems, in that it calls for bilingual services specific to an Asian group. In other words, a Chinese person with little knowledge of English 
who wishes aid from a social service agency has a need for a Chinese-speaking staff worker. In addition, certain problem areas are more frequent or more severe in some Asian groups than in the general population. Problems of the Asian elderly are compounded by circumstances unique to their ethnicity, such as lack of language ability, reticence in revealing problems to outsiders, inability to eat American food, and other cultural differences from white society. Mental health problems seem to occur frequently among Chinese, but are often not reported. 11

Review of Problem Areas in Asian Communities

Most of the major needs and problems of Chinese and other Asian communities have been discussed in previous chapters. We wish to briefly review them here. Rose Hum Lee lists the major social problems of Chinese as housing discrimination, health care, mental health, old age, juvenile delinquency and neglected children, and gangs. 12

In Portland, we feel that the most important problems are those affecting Chinese senior citizens, as outlined above. The problems of recent immigrants are also significant. These include lack of English-speaking ability, unemployment, difficulty in gaining professional certification and culture shock. There are also 
some problems involved in a lack of communication and understanding between the older and younger generations, and there is a very limited amount of juvenile delinquency.

A 1973 study by Laura Sing et. al. surveyed the opinions of Portland Chinese as to what services would be most useful. The services most frequently mentioned were: 1.) Care and assistance of the aged; 2.) Ianguage education for non-English speaking Chinese; 3) Vocational help; and 4.) Health and medical care. 13

In December of 1977, the Chinese Information Service conducted a survey of community needs for information about services. This survey was distributed to 350 Chinese through the Chinese churches, and a response rate of $25 \%$ was achieved. Areas in which Chinese wanted more information included immigration, drivers' licenses, welfare, taxes, language training, consumer protection, and locations of Chinese literature in libraries. BARRIERS TO SERVICE

The important factor concerning these needs and problems is not that they exist--all elements of the population have problems--but that they have not been addressed by the social service delivery system. This is partly due to the fact that they have not been recognized, because of factors outlined above. But there also exist significant barriers that make tradi- 
tional social services inaccessible to Asian Americans.

The Council on Social Work Educations Asian

American Task Force says that:

The systematic exclusion of Asian Americans from using and sharing resources through barriers such as language differences and difficulty in comprehending the routes to obtain institutional services is a particular problem for most Asian Americans. $14^{\circ}$

Powerlessness

Some of the problems of the Asian communities-especially the large Chinatown ghettos-result from the lingering effects of racial oppression and internal colonialism. Juvenile delinquency, youth gangs, poverty and low-wage employment are all symptoms of the powerlessness of the Chinese people in these ghettos, their frustration with the existing conditions, and their continued lack of equal opportunity.

The Nees point out that social agencies in Chinatown have not been at all effective in alleviating such difficulties:

At best, the government agencies can provide residents of Chinatown with temporary. "bandaid services" to alleviate these long-term needs; at worst they divert attention from the critical problems of the community with a labyrinth of bureaucratic paperwork. 15

The direct way to deal with this problem would involve an effort to increase the power of such communities. The CSWE Asian American Task Force therefore contends that: 
The primary criterion in evaluating the effectiveness of a social program is therefore its degree of power-producing potential; that is, does it enhance the communitys power and autonomy .... In summary, the social work practitioner model that is relevant to Asian American communities will not only aim at securing services for clients and helping them to function more effectively in their environment, but also deal with the relevant people and institutions in the clients' environment that are denying them self-determination and equal opportunity. 16

Lack of Cultural Sensitivity

Asians often do not benefit from the services provided by social agencies, because these services are culturally irrelevant. Treatment methods have been designed by and for white middle-class people.

Sue and Sue point out that:

Because there are cultural determinants of behavior, and counseling is essentially a white middle class activity, it may be necessary to modify counseling approaches. This is especiaffy true with many Chinese-American counselees. 17

Alex Leung makes the same observation concerning mental health services to the Chinese:

...psychotherapy is essentially a white-middle-class activity. It is intended for someone with high verbal functioning, a willingness to express emotions and great tolerance for ambiquity. I8

And Kalish and Yuen provide an example of difficulties that might be caused by a lack of cultural understanding:

Frequently well-intentioned attempts to help only exacerbate the situation. Thus a non-Asian welfare worker is likely to respond negatively to the discovery that her elderly client is buying rare medicinal herbs or is giving gifts to his friends...19 
We believe it is possible for non-Asian social service workers to effectively provide services to Asians, but that cultural sensitivity and knowledge are necessary. Need for Bilingual Staff

An important barrier to services encountered by Asians is the lack of bilingual staff in social service agencies--even agencies located in areas with large Asian populations.

Unfortunately, the people in Asian communities most likely to be in need of services--the aged and the recent immigrants--are also the people least likely to know English. If a common language between caseworker and client does not exist, little can be done in the way of counseling. Even applying for services such as welfare or food stamps can be difficult and frightening for a non-English speaker.

Hearings held by the California Advisory Committee to the U.S. Commission on Civil Rights revealed that, regarding social services for Asians,

The major focus of testimony in this area was on the need for bilingual services and a deeper committment on the part of social service agencies to help those entrusted to their care.21

But agencies seem reluctant to provide such services. Kuramoto writes of the struggle of Asians in Los Angeles to get the local welfare department to even admit that bilingual workers were necessary. The department 
eventually conceded that twenty such workers were needed, but evidently only one person was hired. Kuramoto also says that a psychiatric hospital which was federally funded to provide services to the Los Angeles Chinatown has nevertheless refused to hire any Chinesespeaking staff. 22

An important factor accounting for the lack of bilingual and bicultural staff in agencies serving Asians is the fact that few Asian social workers are being trained. The Asian American Task Force of the CSWE says:

Schools of social work have ignored the problems both of foreign-born Asians and of Asian Americans in the United States and have accepted the myth that Asians have no social problems.23

And in evaluating the number of Asian social workers trained by West Coast schools of social work, the Task Force states:

... in 1969 and 1970 there was only token representation of 2 or 3 percent Asian American students in certain schools that serve communities with sizable Asian populations...24

The Task Force recommended that more Asian social workers be trained, and that field placements with the Asian community be developed at schools in cities with sizable Asian populations. 25

Often, however, Asian social workers do not work in the Asian community, whether because of their own career goals or because of lack of opportunity. In addition, their training has often been irrelevent in 
preparing them to work in Asian Communities. Again, the Asian American Task Force reports that:

The fact that most Asian practitioners have had the traditional training of the white-middle-class-oriented school, with a heavily psychoanalytic orientation, creates additional stress. They find it difficult to make the transition from their prior training and practice to the requirements of Asian communities, which call for knowledge and skills directed more to institutional than to individual change. 26

An organization called the Asian American Social Workers (AASW) was formed in the late 1960s to obtain more training, services, and community control for Asians. They have been successful in helping recruit Asians for schools of social work, and in organizing research projects concerned with social services for Asians. 27

\section{Cultural Factors Leading to Under-Utilization of Services}

Insensitivity of social service agencies to the needs of Asian communities is an important reason for the under-utilization of such services by Asians; but there are also cultural factors which make Asians reluctant to seek help from agencies outside their own community.

In traditional Chinese society, individual problems were handled within the family structure. Admission to outsiders that they could not be handled by the family, or even that they existed, would have brought shame on both the family and the individual.

Such attitudes are still present in Chinese communities today. We mentioned in the last chapter that one of 
our interviewees, in recounting visits to Chinese in nursing homes by several community groups, pointed out that only those Chinese without families were visited; to visit a person who already had a family to care for him would have been seen as an intrusion. Sue and Sue, in describing the case of a Chinese-American student, who was being counseled for difficulties in school, said:

Much of his earlier difficulties in opening up were caused by his feelings of shame and guilt at having come to a counselor. He was concerned that his family might discover his seeking of help and that it would be a disgrace to them 28

In addition, Chinese culture values a certain reticence or stoicism on the part of the individual. Emotions and problems are not readily expressed. Americans are more open, more gregarious; a white American will generally readily express his feelings toward anyone or anything.

Reiko Homma-True, in a report of a survey of residents of the Oakland, California Chinatown, observes that:

Despite the fact that 22 percent of Chinatown residents are below the poverty level, only 2.6 percent of the respondents were willing to mention financial problems as a major concern. 29

A survey by Sing et. al. on Chinese attitudes and knowledge concerning social services in Portland shows that while $34 \%$ of the survey respondents felt it very 
acceptable for Chinese to seek assistance from a social service agency, $40 \%$ would consider relatives as the first source of aid in a financial emergency. 30

Such under-utilization of services could be partially alleviated by a greater understanding and sensitivity on the part of agency personnel to the attitudes and culture of Asian peoples. But the considerations detailed above all seem to indicate that the problems of Chinese might be handled most effectively within the community, through the established system of mutual support organizations.

Asian Community Participation in Social Service Programs

The CSWE Asian American Task Force report calls for both greater community participation in programs for Asians, and more attention to the structure of Asian communities in the training of social workers:

Asian Americans demand to be included in the development of social service programs, in administering the resources mobilized, and in having a place in policymaking bodies to be heard and to influence policy decisions... There is no consideration of Asian American experiences in the education of social work practitioners, and the curriculum ignores the self-help and mutual-aid social survival techniques of Asian American communities. 31

We have seen that within the Portland Chinese community, there are many efforts to provide services to Chinese in need, but that due to a lack of resources, these programs cannot reach too many people. One person 
we talked with made a case for governmental support of programs within the Chinese community. She pointed out that the organizational structure and committment exists to provide services, but resources are lacking.

We intend to take care of the problems of our own people, which then alleviates the government and the state from the problems that the Chinese people do have... Were touching areas that its much easier if we try to do it under our own group.

DESIGN OF SERVICES TO ASIANS

The factors detailed above suggest some considerations which should be taken into account in designing social service programs for the Chinese or other Asian groups.

We have documented in this paper a system of mutual support organizations indigenous to the community. There is thus a formal organizational structure designed by and appropriate to the Chinese community which already exists. Traditional values, such as strong family allegiance, also indicate that there is likely to be a highly developed informal, "natural" network of support within the community. Any design of social services to the Chinese community should therefore be community-based and should involve community leaders and members in its planning and operation. This would ensure that cultural considerations are taken into account in the design of the program, and make sure that existing mutual support patters within the community 
are utilized. The model of service delivery in such a case is not one of individual services; but more a community organization model, involving facilitating activities on the part of the service worker which allow the community itself to make use of its own resources and organizational structure in dealing with its needs and problems.

In addition, program staff should to the greatest extent possible be bilingual and bicultural; preferably they should themselves be members of the community. Homma-True asserts that:

availability of bilingual staff is a key element in the successful utilization of a program, particularly a program offering exploration of complex interpersonal and personal problems.32

There would also be advantages to a single agency providing multiple services to a given community. For example, the CCBA in Portland conducts English classes, the Chinese Language School, an information and referral service, and various cultural and social activities. Anyone in the Chinese community who desires social services can contact one location--the CCBA--and either be provided with the service or directed to an agency where the service can be provided.

It is debatable whether agencies serving Asian communities should be designed to serve more than one Asian group. In Chapter IX, we discussed the difficulties 
in achieving cooperation between different Asian populations. If the center would be under community control, a question would arise as to which community would have control, or how power might be shared between the different ethnic groups. An attempt to serve more than one group would also necessitate a larger staff in order to include workers fluent in the languages and knowledgeable about the cultures of all groups involved.

Advantages of such a design, however, would include the possibility that resources and ideas could be shared. Also, Asians in total represent only a small percentage of the population; individual Asian populations could increase their power and resources by forming coalitions with other groups.

Examples of Social Service Agencies for Asians

Although the social service establishment has paid little attention to the needs and problems of AsianAmericans, there are a few examples of Asian social service agencies. Most of these exist in areas where there are large Asian populations.

We have mentioned (in Chapter VIII) some of the service programs organized by radical groups in the San Francisco Chinatown. There is also a Youth Services Center in this community, designed to aid and counsel 
delinquent Chinese youth. 33 In the New York Chinatown, there is a Community Services Society, which provides health services and counseling to families and to the elderly; the Chinatown Planning Council, a multi-service center providing day care, English classes, information and referral, counseling, tutoring, and youth programs; and the Chinatown Youth Council, which provides English classes, job placement, counseling, and social programs to Chinese youth. 34 In Los Angeles, there is an Oriental Service Center which has bilingual Chinese, Filipino, Japanese, Korean, and Samoan workers. 35

In Portland, as we have seen, most social services for Asians operate within the framework of traditional Asian community organizations, and have little funding (mostly in the form of CETA grants) and few staff. Some local colleges, such as Portland Community College and Reed College, have provided English classes to various immigrant groups. There is an Indochinese Center, which has recently lost its federal funding, which provides a variety of services to Indochinese refugees.

The Portland Korean community operates a Korean senior citizens center in space donated by Lambert House (a senior citizens day care center) at Southeast 28 th and Steele. This center is operated by the KoreanAmerican Senior Citizens' Society, which currently has 
over a hundred and twenty members. It provides English classes, information and referral, social activities, some transportation services, and a program designed to reduce the social isolation of elderly Koreans, whereby these people work as volunteers for agencies such as the Red Cross and American Cancer Society. The program is notable in that it is the only service program for Korean senior citizens of which we are aware.

The writer was involved in helping the Korean senior citizens receive funding for this program, and was impressed by the lack of interest by funding agencies in the project. Both govermmental agencies and private foundations turned down requests for funding, and the program now operates with facilities donated by various sources, donations of funds from the Korean community, and one staff person funded by CETA.

THE ROLE OF THE PROFESSIONAL IN ORGANIZING SERVICES TO ASIANS

We have observed that insensitivity on the part of staff workers in social service agencies has contributed to the inaccessibility of such services to Asians. But individuals who plan and implement social services may Also be insensitive to the needs of Asian-Americans. We have mentioned that counseling is a primarily white middle-class activity; we might also mention that the 
game observation could be applied to planning and program development activities.

We have argued that services to Asian communities should be organized and operated within the community, and as much as possible staffed by community members. But many communities wishing to provide such services lack expertise in program dessign, grant-writing, and other skills necessary to developing a program. In such cases, a social planner or consultant might be able to offer valuable assistance. But the question arises as to what the role of a professional social service planner or community organizer from outside the community should be. We feel that professional expertise can be a valuable resource to Asian communities, but that the role of the professional must be limited by several considerations.

\section{Cultural Sensitivity}

Cultural sensitivity is just as necessary for an individual who plans services for an Asian community as it is for a person who provides services. Preferably, he should take the role of an advisor, and let the community do most of the planning while he merely offers technical assistance. In order to function in such a role, the planner or community organizer must be aware of the structure of the community, the functions of community organizations, and the cultural, historical, and socio-economic background of the community.

Iaura Sing et. al. write that: 
...because of the traditional value of self-reliance of the Chinese, the professional should seek, through his work with individuals, groups, and communities, to help the chinese find within the Chinese community the resources for solving both the problems that affect them individuelly and those that effect them as a group.

The role of the professional is thus not to tell people what they need, but to find out what they need from them, and then interpret those needs to the agencies that can provide the resources to meot them.

Technical Assistance

The planner can act as a consultant to an Asian comanity about how to obtain the resources they need. The Asian American Task Force of the CSWE points out that:

One serious deficiency among those who organize within the community is the lack of understanding of the bureaucratic structure of agencies to which they relate (in whatever manner) as they go about their daily business. Many not only do not undergtand how policies are made; they do not even know where decisions are made. 37

The professional can provide community leaders with such information.

Funding

We have seen that the key barrier to the organization of social services within the Asian communities is a lack of funding. The professional can help gain such funding by providing contacts and access to government and private funding sources, and the expertise necessary for grant and proposal writing. 
Research

Very little research has been done on Asian communities, their needs, and their problems. This fact in part accounts for the lack of interest in the social service establishment in programs for Asian-Americans. If more research and documentation concerning needs within these communities and ways to meet these needs was available, more understanding might be generated within the social service structure. Needs assessment research is also important to any efforts in proposal writing. The professional can thus be of benefit to Asian communities by conducting such research.

At present, we are aware of only two agencies engaged in research on Asian community problems. An organization in the San Francisco Chinatown called Self Help for the Flderly has a research project focusing on the problems of Chirese senior citizens. 38 Also, there is an agency in San Diego called the Asian American Mentaz Health Research Center (AAMHRC), which was established through the efforts of the AASW and is funded by the National Institute of Mental Health. 39

\section{SUMMARY}

In this chapter, we have attempted to establish that there is a definite need for social services designed for Asian communities. Such services should be designed and operated by the community itself, and should to the extent possible utilize bilingual and culturally sensitive staff. 
We have seen that traditional social service agencies often do not meet the needs of Asian Americans, due to a lack of knowledge about those needs and vaious barriers which reduce the accessibility of such services to Asians. 


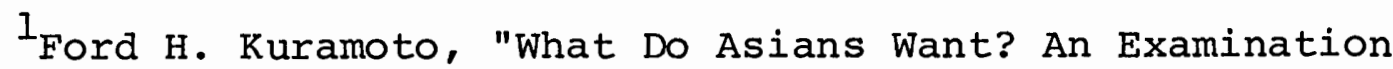
of Issues in Social Work Education", Journal of Education for Social Work, VII, (Fall 1971), p. 13.

${ }^{2}$ Richard A. Kalish and Sam Yuen, "Americans of East Asian Ancestry: Aging and the Aged", The Gerontologist, II, Part II, ( Spring 1972), p. 37.

${ }^{3}$ Victor G. and Brett De Bary Nee, Longtime Californ': A Documentary Study of an American Chinatown, (N.Y.: Pantheon Books, 1973), p. 345.

${ }^{4}$ Pei-ngor Chen, "The Chinese Community in Los Angeles", Social Casework, LI, (December 1970), p. 591.

${ }^{5}$ Derald wing sue and Stanley Sue, "Couseling ChineseAmericans", The Personnel and Guidance Journal, L, (April 1972), p. $63 \overline{7}$.

6 Dean Lan, Prestige with Limitations: Realities of the Chinese American Elite, (San Francisco: $R$ and $E$ Research Associates, 1976), p. v.

7 Kuramoto, p. 11 .

8 "Success Story of One Minority Group in the U.S.", U.S. News and World Report, December 26, 1966, p. 73.

${ }^{9}$ Nee, p. 345 .

10"Chinese Feel Overlooked in Minority Funding", Oregonian, Aug. 7, 1975, p. B9 c. 4-8.

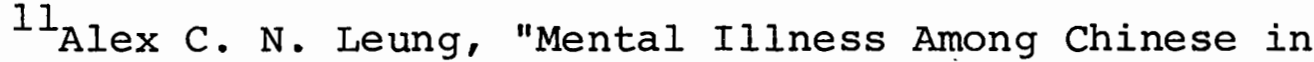
the United States: Myth or Reality?", (Masters thesis in Psychology, Portland State University, 1976), p. 1; and Stanley Sue and Derald W. Sue, "Chinese American Personality and Mental Health", in Roots: An Asian American Reader, Amy Tachiki, Eddie Wong, Franklin Odo, and Buck Wong, editors, (Los Angleles: UCLA Asian American Studies Center, 1971). p. 80.

12 Rose Hum Lee, The Chinese in the United States of America, (Hong Kong: Hong Kong University Press, 1960), pp. 300-352.

${ }^{13}$ Laura Lum Sing, Wendy Po-kow Chan, and Peter Tan-ping Wong, "Chinese Attitudes and Knowledge Concerning Social Services: A Survey of the Portland Chinese Community", (Master 
of Social Work practicum, Portland State University, 1973), Table B, "Overview of Respondent Attitudes and Knowledge Concerning Social Services", p. 37.

${ }^{14}$ Council on Social Work Education, Asian American Task Force, Asian American Task Force Report: Problems and Issues in Social Work Education, (N.Y.: CSWE, 1973), p. 40.

${ }^{15}$ Nee, pp. 357-358.

${ }^{16}$ Council on Social Work Education, pp. 2-3.

${ }^{17}$ Sue and Sue, "Counseling Chinese Americans", p. 644.

${ }^{18}$ Leung, p. 5 .

${ }^{19}$ Kalish and Yuen, p. 45 .

${ }^{20}$ For a case study involving an evaluation of cultural factors and treatment considerations, see Berta Fantl, "Cultural Factors in Family Diagnosis of a Chinese Family", International Journal of Social Psychology, V, (Summer 1959).

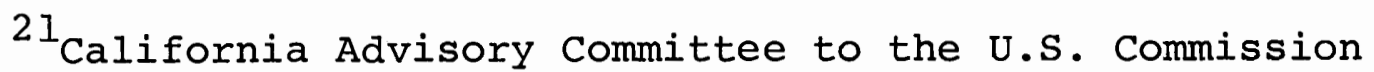
on Civil Rights, Asian Americans and Pacific Peoples: A Case of Mistaken Identity, (Washington: U.S. Commission on Civil Rights, 1975), p. 35 .

22 Kuramoto, p. 15.

${ }^{23}$ Council on Social Work Education, p. 31.

24 ibid., p. 19.

25 ibid., pp. 34-35.

26 ibid., p. 27.

27 Arlene Hori Kushida, Marilyn Montenegro, Paul Chikahisa, and Royal. F. Morales, "A Training Program for Asian and Pacific Islander Americans", Social Casework, LVII, (March 1976), pp. 186-187; and Kuramoto, p. 15.

${ }^{28}$ Sue and Sue, "Counseling Chinese Americans", p. 639.

29 Reiko Homma-True, "Characteristics of Contrasting Chinatowns; 2. Oakland, California", Social Casework, LVII, (March 1976), p. 157.

${ }^{30}$ Sing et. al., Table B, "Overview of Respondent Attitudes and Knowledge Concerning Social Services", pp. 35-37. 
${ }^{31}$ Council on Social Work Education, p. 41.

32 Homma-True, p. 158.

33 "An Interview with L. Ling-Chi-Wang", from Tachiki et. al., op. cit., p. 275.

${ }^{34}$ Rocky Chin, "New York Chinatown Today: Community in Crisis", from Tachiki et. al., op. cit., pp. 283-284.

35 Kuramoto, p. 15 .

${ }^{36}$ sing et. al., p. 62 .

${ }^{37}$ Council on Social Work Education, p. 9.

${ }^{38}$ Kalish and Yuen, p. 41.

${ }^{39}$ William T. Liu and Mariko Yamada, "The Asian American Mental Health Research Center", Social Casework, LVII, (March 1976). 
CHAPTER XI

SUMMARY AND CONCLUSIONS

In this paper, we have attempted to review the history of the Chinese in Portland, Oregon, from their first arrival in 1851 up to the present day. In particular, we have focused on formal mutual support systems within the Portland Chinese community. We have observed the way in which the type of organizations present in the community, and the functions of these organizations, have changed over the years, as conditions within the community have changed.

In the early years of the Chinese presence in Portland, the community consisted primarly of bachelor male laborers, who provided much of the labor necessary for the economic development of Oregon. There was an incredible amount of hostility directed against the Chinese. Chinese organizations at this time reflected these conditions. They took the form of organizations which were traditionally found in China at the time, and had the function of providing protection to the Chinese against hostile conditions, finding work for Chinese, and providing a support group . for the lonely bachelor males.

Around the turn of the century, a small American-born generation of Chinese began to develop. This group was to 
some extent isolated from both the Chinese-born generation and the white American population, and formed organizations designed to both promote the rights of Chinese in America and to provide support for each other within the Chinese community.

In the first half of the twentieth century, many of the bachelor laborers died or returned to China. The Chinese community decreased in population, but many families began to form within the community, primarily among the merchants. The male-female ratio became much more equalized, and the Chinese became more accepted by the white community. Many families were able to move away from Chinatown into predominantly white neighborhoods. The older generation began to be concerned that chinese culture and values were being lost among the younger, American-born generation.

Organizations of this period reflect these interests. A Chinese Language School was formed so that the American-born Chinese would be able to speak Chinese. Various cultural organizations appeared. The traditional Chinese-type organizations declined in membership and influence, but continued to exist. Two Chinese Christian churches, the only survivors from a large number of Chinese missions which had been active in previous years, became active and influential in the community, providing a variety of services.

After World War II Chinese became much more accepted in American society. Opportunities in employment and housing 
opened up for the Portland Chinese. Chinese were for the first time able to become naturalized American citizens. The Chinese community became much more Americanized, and the Portland Chinatown virtually ceased to exist.

The Chinese continued to retain a sense of identity, however. The organizations in the Chinese community continued to exist, and placed much of their emphasis on retention of Chinese language, traditions, and culture. There was a new emphasis in these organizations on social services to disadvantaged segments of the Chinese community, such as the aged.

In the 1960's, immigration laws were liberalized, resulting in a new wave of immigration from China and other Asian countries. These immigrants were fairly well prepared for life in America, and included a large number of well-educated and professional people. But the recent immigrants in the Portland area nevertheless have some problems in finding employment, learning English, and adjusting to American life. They are to some extent isolated from both the white and the established chinese communities. Chinese community organizations have attempted to provide some services to this group, although they are limited by a lack of resources.

PRESENTATION OF DATA IN THE THESIS

In addition to data on the chinese community, we have presented a great deal of background information on social, 
economic, and political conditions in China in the nineteenth century, and on American relations with the Chinese.

We have also presented information on present and former conditions in other chinese communities throughout the United States, and have used this data as a basis for comparison of the situation in Portland with other communities.

We have used a variety of sources-- scholarly literature, historical records and documents, newspaper articles, and interviews conducted with members of the Chinese community-- and we have organized data from all of these sources in a chronological, narrative form.

We are aware of many methodological defects and gaps in our narrative. Our interview sample should have been larger and more representative of the Chinese community. Several gaps in our narrative might have been filled in by more thorough investigation. But we were severely limited in the amount of time and resources available to us. We regard this thesis as a preliminary study, in which we have been able to collect and put into coherent form a large variety of data on the Chinese community in Portland. We hope that this study will prove valuable as a basis for future research, and will help to improve understanding of the chinese community.

\section{OBSERVATIONS AND CONCLUSIONS}

In this thesis, we have made several observations about the Chinese experience in Portland and in America. 
The Mechanics of Racism

We have attempted to analyse the motivations, mechanics, and history of racism and discrimination against the Chinese in America and in Portland. We conclude that through most of the history of the Chinese in America, these people have been put in the position of a colonized minority. They have been used as a ready source of unskilled labor, but have been prevented from entering the mainstream of American life. All aspects of their living situation-- employment, housing, family life, citizenship, immigration-- were subject to restrictions imposed by a system of institutional racism.

Such discrimination resulted not only from race consciousness and ideas of white supremacy, but from the economic conditions of the time, and from the conditions and attitudes arising from Western colonial incursions in China.

Only recently have Chinese-Americans been able to achieve some degree of equal opportunity in American society, and even now there is a subtle, lingering form of racial stereotyping and discrimination against the Chinese.

Such historical experiences have had a profound effect on the present structure of the Chinese community and on Chinese attitudes towards their racial identity.

We have seen that the usual Chinese response to racism was accomadation; not making waves. As Dean Lan writes: When the economic climate became historically unbearable in California, the Chinese reacted by moving east- 
ward. If the American courts denied him justice, he bypassed them and set up his own organizations to settle differences among his fellows. He kept his contacts with the larger American society to a minimum; he never intruded but neither did he resign himself to permanent subordinancy.

We have seen that Chinese have accepted all that it was possible for them to accept; but when it was possible for them to fight back, they have fought back-- Chinese labor unions have been formed; Chinese in Portland have struggled for the right to buy houses wherever they pleased, etc.

We also believe that the experiences of the Chinese with white racism-- the barriers that whites erected to keep Chinese apart from the rest of society-- have contributed to the strong sense of community among the Chinese today. In the old days, the chinese had to draw together and help one another out to survive; no one else would help them. They had to draw on their traditional culture for support; they were denied the white culture. We believe that such experiences contributed to the strong desire in the Chinese community today to retain the traditional Chinese culture.

The Ideal of the Plural Society

We believe that the values and traditions of the chinese community are eminently acceptable in contemporary society today. The emphasis on mutual support and cooperation over individualism, the tradition of caring for the elderly, the respect shown for scholarly achievement are all worthwhile values; and the argument that these should be submerged in the "Melting Pot" of the white middle-class life style is there- 
fore questionable.

The "Melting Pot" ideal may appear fine in theory. In practice, it has a number of defects. For one thing, Asians and other people of color have never been given the opportunity to "melt" as equals with whites.

In addition, conformity of all groups to the mass culture of America would be monotonous. Mutual understanding and respect between all groups in the population is obviously desirable; but this does not necessarily require that these groups become identical.

We thus favor a plural society, and believe that attempts of ethnic groups to retain a distinct identity in the population should be encouraged. We feel that a diversity of ideas, customs, cultures, and values makes for a more dynamic and humanistic society.

Social Services for Ethnic Minorities

We further conclude from our presentation that separate, community-designed services for ethnic minorities are essential to meet the distinct needs and problems of these groups. A greater understanding of the present situation and historical experience of Asian Americans by the social service structure is necessary; and more support for community endeavors to provide services is essential.

We believe that the system of mutual support organizations within the Chinese community, as we have described it, shows that community-designed and operated services can be 
viable and effective, if they have the support and understanding of the social service establishment.

\section{Continuation of the Chinese Community}

At present, the established Chinese community in Portland appears to be becoming almost indistinguishable from the predominent white community. The Chinese have retained their cultural traditions to some degree, but whether they will continue to retain a sense of ethnic identity in the future is unknown.

The constant influx of new immigrants, however, will ensure that there will always be a group of Chinese in Portland in the process of adjustment to American life.

We believe that there will continue to be some form of distinct Chinese community in the foreseeable future. We hope that the system of mutual support and assistance within this community will also continue, and that it will gain the understanding and support of the majority society. 
CHAPTER XI: FOOTNOTES

${ }^{1}$ Dean Lan, Prestige with Limitations: Realities of the Chinese American Elite, (San Francisco: $R$ and $E$ Research Associates, 1976), p. 26 . 
BIBLIOGRAPHY 


\section{BIBLIOGRAPHY}

\section{Books}

Asian-American Advisory Council to the Governor of the State of Washington, Report to the Governor on Discrimination Against Asians, Seattle: Asian-American Advisory Council, 1973.

Barth, Gunther, Bitter Strength; A History of the Chinese in the United States, 1850-1870, Cambridge, Mass.: Harvard University Press, 1964 .

Bee, Frederick A., The Other Side of the Chinese Question-Testimony of California's leading Citizens, San Francisco: Woodward and Co., Printers, 1888; reprint ed., San Francisco: $R$ and $E$ Research Associates, 1970.

Blauner, Robert, Racial Oppression in America, N.Y.: Harper and Row, Publishers, 1972 .

Carey, Charles Henry, History of Oregon, Chicago-Portland: Pioneer Historical Publishing Co., 1922 .

Chiu, Ping, Chinese Labor in California, 1850-1880, Madison, Wisc.: University of Wisconsin, 1963.

Clark, Malcolm, Jr., Pharisee Among Philistines: The Diary of Judge Matthew Deady, Portland: Oregon Historical Society, 1975 .

Clark, Robert Carlton, History of the Willamette Valley, Oregon, Portland: S.J. Clarke Publishing Co., 1927.

- Coolidge, Mary Roberts, Chinese Immigration, N.Y.: Henry Holt and Co., 1909; reprint ed., N.Y.: Arno Press and The New York Times, 1969.

Corning, Howard M., Dictionary of Oregon History, Portland: Binfords and Mort, Publishers, 1956.

Council on Social Work Education, Asian American Task Force, Asian American Task Force Report: Problems and Issues in Social Work Education, N.Y.: Council on Social Work Education, 1973 .

Daniels, Roger, and Harry H.L. Kitano, American Racism: 
Exploration of the Nature of Prejudice, Englewood Cliffs, N.J.: Prentice-Hall, Inc., 1970.

Del French, Chauncey, Railroadman, N.Y.: MacMillan and Co., 1938 .

Dodds, Gordon B., The Salmon King of Oregon, Chapel Hill, N.C.: University of North Carolina Press, 1959.

Dow, Edson, Passes to the North: History of the Wenatchee Mountains, Wenatchee, Wash.: Outdoor Publishing Co., 1963.

Edson, Christopher Howard, The Chinese in Eastern Oregon, 18601890, San Francisco: $\mathrm{R}$ and E Research Associates, 1974.

Gaston, Joseph, Portland, Oregon: Its History and Builders, Portland: s.J. Clarke, 1911.

Givens, Helen Lewis, The Korean Community in Los Angeles County, San Francisco: $R$ and E Research Associates, 1974; from a thesis written in 1939.

Gompers, Samuel, and Herman Gutstadt, Meat vs. Rice; American Manhood Against Asiatic Coolieism; Which Shall Survive?, San Francisco: American Federation of Labor and the Asiatic Exclusion League, 1908.

Holbrook, Stewart A., The Columbia, N.Y.: Rinehart and Co., 195.6 .

Hundley, Norris, Jr., editor, The Asian American: The Historical Experience, Santa Barbara: Clio Press, Inc., 1976 .

I Wor Kuen, Chinese-American Workers, Past and Present-- An Anthology of Getting Together, San Francisco: I Wor Kuen, Z1973?.

An Illustrated History of Union and Wallowa Counties, Western Historical Publishing Co., 1902.

Johansen, Dorothy O., Empire of the Columbia, N.Y.: Harper and Row, Publishers, 1967.

Kitano, Harry H.L., Japanese-Americans: The Evolution of a Subculture, Englewood Cliffs, N.J.: Prentice-Hall, Inc., 1969 .

Kung, Shien Woo, Chinese in American Life, Seattle: University of Washington Press, 1962 .

Lan, Dean, Prestige with Limitations: Realities of the 
Chinese-American Flite, San Francisco: R and E Research Associates, 1976 .

Lee, Rose Hum, The Chinese in the United States of America, Hong Kong: Hong Kong University Press, 1960.

Light, Ivan H., Ethnic Enterprise in America: Business and Welfare Among Chinese, Japanese, and Blacks, Berkeley: University of California Press, 1972 .

Lockley, Fred, History of the Columbia River Valley, ChicagoPortland: S.J. Clarke Publishing Co., 1928 .

Lomax, Alfred L., Pioneer Woolen Mills in Oregon, Portland: Binfords and Mort, Publishers, 1941.

McClellan, Robert, The Heathen Chinee; A Study of American Attitudes Toward China, 1890-1905, Columbus, Ohio: Ohio State University Press, 1971.

McWilliams, Carey, Brothers Under the Skin, Boston: Iittle, Brown and Co., 1943 .

Maddux, Percy, City on the Willamette: The Story of Portland, Oregon, Portland; Binfords and Mort, Publishers, 1952 .

Meinig, D.W., The Great Columbia Plain, Seattle: University of Washington Press, 1968.

Melendy, H. Brett, The Oriental Americans, N.Y.: Twayne Publishers, Inc., 1972 .

Mitchell, John H., Immigration of Chinese: Speech of Hon. John H. Mitchell of Oregon in the Senate of the United States, May 16, 1876, Washington: Judd and Detweiler, Printers, 1876 .

Nash, Willis, Two Years in Oregon, N.Y.: D. Appleton and Co., 1882 .

National Editorial Assciation, Portland, Oregon, 1899.

Portland: National Editorial Association, 1899.

Nee, Victor G., and Bret De Bary Nee, Longtime Californ': A Documentary Study of an American Chinatown, N.Y.: Pantheon Books, 1973.

Oregon State Health Division, Vital Statistics Section, Oregon Public Health Statistics Report for Calendar Year 1976, Portland: Oregon State Health Division, 1977.

Peterson, Emil R., and Alfred Powers, A Century of Coos and 
Curry, Portland: Binfords and Mort, Publishers, 1952.

Samuel's Portland Directory, Portland: Geo. Himes and Co., Printers; various annual editions cited from 1873-1880.

-Sandmeyer, Elmer C., The Anti-Chinese Movement in California, Urbana, Ill.: University of Illinois Press, 1973.

Saxton, Alexander, The Indispensible Enemy; Labor and the Anti-Chinese Movement in California, Berkeley: University of California Press, 1971.

Scott, Harvey W., editor, History of Portland, Syracuse, N.Y.: D. Mason and Co., 1890 .

'Scott, Leslie M., History of the Oregon Country, Cambridge, Mass.: Riverside Press, 1924.

Six Chinese Companies, Memorial; An Address to the Senate and House of Representatives of the United States, San Francisco: Six Chinese Companies, 1877; reprint ed., San Francisco: R and E Research Associates, 1970.

Stearns, Marjorie R., The History of the Japanese People in Oregon, San Francisco: $R$ and E Research Associates, 1974; from a thesis written in 1937.

Steel, R. W., and Seid Back, Jr., Chinese Souvenir of the Lewis and Clark Centennial Exposition, Portland: R. W. Steel and Seid Back, Jr., 1905.

Steinfield, Melvin, editor, Cracks in the Melting Pot; Racism and Discrimination in American History, BeverIy Hills, Cal.: Glencoe Press, 1970.

Tachiki, Amy, Eddie Wong, Franklin Odo, and Buck Wong, editors, Roots: An Asian American Reader, Los Angeles: UCLA Asian American Studies Center, 1971.

U.S. Commission on Civil Rights, California Advisory Committee, Asian Americans and Pacific Peoples: A Case of Mistaken Identity, Washington: U.S. Commission on Civil Rights, 1975.

U.S. Department of Commerce, Bureau of the Census, Population of the United States in 1860, Eighth Census, Washington: U.S. Department of Commerce, 1860 .

1970 Census of Population and Housing, Portland Oregon-Washington SMSA, Washington: U.S. Department of Commerce, 1970 .

Urban Associates, Inc., A Study of Selected Socio-Economic 
Characteristics of Ethnic Minorities Based on the 1970 Census, Vol. IV, "HEW Regional Data", Washington: Department of Health, Education and Welfare, 1974.

Waley, Arthur, Three Ways of Thought in Ancient China, Garden City, N.Y.: Doubleday and Co., Inc., 1939 .

Warren, Sidney, Farthest Frontier, N.Y.: MacMillan and Co., 1949 .

Wei Min She Labor Committee, Chinese Working People in America, San Francisco: United Front Press, 1974.

Weiss, Melford S., Valley City: A Chinese Community in America, Cambridge, Mass.: Schenkman Publishing Co., 1974.

Winther, Oscar Osburn, The Great Northwest, N.Y.: Alfred Knopf, 1950 .

Wong, James I., Aspirations and Frustrations of the Chinese Youth in the San Francisco Bay Area: Aspersions upon the Societal Scheme, San Francisco: $R$ and E Research Associates, 1977.

Wong, Karen C., Chinese History in the Pacific Northwest, privately printed, /Seattle?_/, 1972.

Wu, Cheng-tsu, editor, "Chink!", N.Y.: World Publishing, 1972.

Periodical Articles

"Abets Discriminatory Attitude", Oregon Voter, October 12, 1946 ; pp. 8-9.

Black, Isabella, "American Labour and Chinese Immigration", Past and Present, No. 25, (July 1963); 59-76.

Bourne, Edward Gaylord, "Aspects of Oregon History Before $1840 "$, Oregon Historical Quarterly, VI, (September 1905); pp.255-275.

Chen, Pei-ngor; "The Chinese Community in Los Angeles", Social Casework, LI, (December 1970); pp. 591-598.

Chin, Leland, "President's Message", Oregon Chinese News, No. 13, (July 1964).

"Chinese Physicians and Dentists Association Formed", Oregon Chinese News, No. 52, (Spring 1977). 
Corbett, P. Scott, and Nancy Parker Corbett, "The Chinese in Oregon, c. 1870-1880", Oregon Historical Quarterly, LXXVIII, (March 1977), pp. 73-85.

Doyle, James, "The Year of the Serpent", Portland Magazine, I, (February/March 1965), pp. 7-13.

Fantl, Berta, "Cultural Factors in Family Diagnosis of a Chinese Family", International Journal of Social Psychiatry, V, (summer 1959), pp. 27-32.

Fujita, Michinari, "The Japanese Associations in America", Social Research, XIII, (March 1976), pp. 211-228.

Hill, Herbert, "Anti-Oriental Agitation and the Rise of Working Class Racism", Society, X, (January/February 1973), pp. 43-54.

Homma-True, Reiko, "Characteristics of Contrasting Chinatowns; 2. Oakland, California", Social Casework, LVII, (March 1976), pp. 155-159.

Ignacio, Lemuel F., "The Pacific/Asian Coalition: Origin, Structure, and Program", Social Casework, LVII, (March 1976), pp. 131-135.

Kalish, Richard A., and Sam Yuen, "Americans of East Asian Ancestry: Aging and the Aged", The Gerontologist, II, Part II, (Spring 1972), pp. 36-47.

Karlin, Jules Alexander, "The Anti-Chinese Outbreaks in Seattle, 1885-1886", Pacific Northwest Quarterly, XXXIX, (April 1948), pp. 103-130.

Kim, Bok-Lim. C., "An Appraisal of Korean Immigrant Service Needs", Social Casework, LVII, (March 1976), pp. 139-148.

Kuramoto, Ford A., "Lessons Learned in the Federal Funding Game", Social Casework, LVII, (March 1976), pp. 208-218.

----- "What Do Asians Want? An Examination of Issues in Social Work Education", Journal of Education for Social Work, VII, (Fall 197I), pp. 7-17.

Kushida, Arlene Hori, Marilyn Montenegro, Paul Chikahisa, and Royal F. Morales, "A Training Program for Asian and Pacific Islanders Americans", Social Casework, LVII, (March 1976), pp. 185-194.

Lee, Rose Hum, "The Decline of Chinatowns in the United States", American Journal of Sociology, LIV, (March 1949), pp. 422-432. 
Liu, William T., and Mariko Yamada, "The'Asian American Mental Health Research Center", Social Casework, LVII, (March 1976), pp. 136-138.

Lott, Juanita Tamayo, "Migration of a Mentality: The Pilipino Community", Social Casework, LVII, (March 1976), pp. 165-172.

Lum, Paul, "A Short History of the Portland CCBA", Oregon Chinese News, No. 46, (March/April 1975), pp. 6-7.

Lyman, Stanford, "Red Guard on Grant Avenue", Trans-Action, VII, (April 1970), pp. 21-34.

Maxwell, Ben, "The Chinese in Salem", Marion County History, VII, (December 1961), pp. 9-15.

Munoz, Faye Untalan, "Pacific Islanders-- A Perplexed, Neglected Minority", Social Casework, LVII, (March 1976), pp. 179-184.

Nickerson, Stepen W., "Our Chinese Treaties; and Legislation; and Their Enforcement", North American Review, CLXXXI, (September 1905), pp. 369-378.

Oregon Chinese News, issues from which untitled articles were cited:

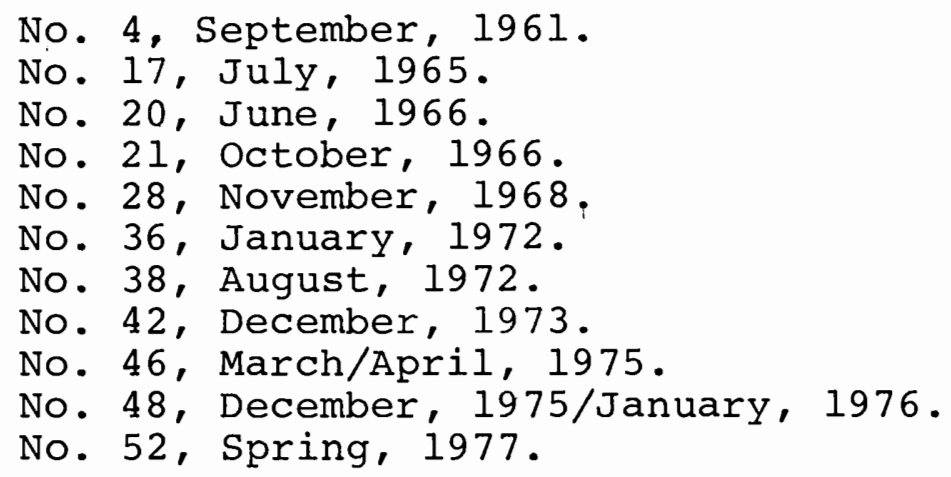

Rice, Berkeley, "The New Gangs of Chinatown", Psychology Today, X, (May 1977), pp. 60-69.

Robertson, James R., "The Social Evolution of Oregon", Oregon Historical Quarterly, III, (March 1902), pp. 1-37.

Speer, William, "Democracy of the Chinese", Harper's New

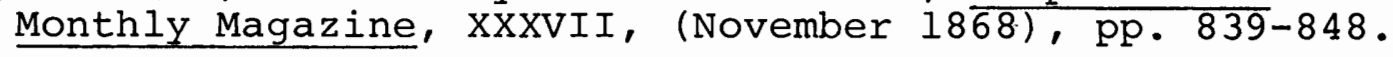

"Success Story of One Minority Group in the U.S.", U.S. News and World Report, LXI, (December 26, 1966), pp. 73-76.

Sue, Donald Wing, and Stanley Sue, "Couseling Chinese-Ameri- 
cans", The Personnel and Guidance Journal, L, (April 1972), pp. 637-644.

Tsang, Gregory Ying-nien, "Editorial Notes", Social Casework, LVII, (March 1976), pp. 219-220.

Wolfe, Tom, "The New Yellow Peril", Esquire, LXXIII, (December 1969), pp. 190ff.

Young, F. G., "Why Oregon Has Not Had an Oriental Problem", American Academy of Political and Social Science, XXXIV, (July/December 1909), pp. 306-310.

Yow, Ho, "Chinese Exclusion, A Benefit or a Harm?", North American Review, CLXXIII, (September 1901), pp. 314-330.

Yuan, D. Y., "Division of Labor Between Native-Born and Foreign-Born Chinese in the United States; A Study of Their Traditional Employments", Phylon, I, (Summer 1969), pp. 160-169.

Yun, Hum, "The Korean Personality and Treatment Considerations", Social Casework, LVII, (March 1976), pp. 173-178.

Newspaper Articles

Articles cited from the Portland Oregonian:

Advertisement, December 6, 1851, p. 3 c. 4 .

"Celestials", March 14, 1857, p. 2 c. 2.

"From Southern Oregon", October 31, 1857, p. 2 c. 3.

Letter from A. Boston, March 25, 1861, p. 2 c. 3.

City Column, June 13, 1863, p. 3 c. 1.

"Opinion of Judge Shattuck", July 1, 1863, p. 2 c. 3-4.

City Column, September 16, 1865, p. 3 c. 1 .

City Column, October 7, 1865, p. 3 c. 1 .

"Protest Against Chinese Labor", April 10, 1867, p. 2 c. 3.

City Column, April 10, 1867, p. 3 c. 1.

City Column, July 27, 1867, p. 3 c. 1.

City Column, September 24,1867, p. 3 c. 2 . 
Letter from Tong Duck Ching, July 24, 1869, p. 3 c. 1 .

City Column, October 12, 1869, p. 3 c. 1 .

City Column, October 16,1871, p. 3 c. 1 .

City Column, January 23, 1873, p. 3 c. 3.

City Column, February 11, 1873, p. 3 c. 1.

City Column, February 13, 1873, p. 3 c. 1.

City Column, March 21, 1873, p. 3 c. 2 .

City Column, June 28,1873, P. 3 c. 1 .

City Column, February 6,1874, p. 3 c. 2 .

"Ordination of Chinese Minister", June 23, 1875, p. 3 c. 2.

City Column, November 7,1877, p. 3 c. 1 .

"Sanguinary Affair", October 4, 1878, p. 3 c. 2 .

"Death of Chin Su Ying", October 7, 1878, p. 3 c. 5 .

City Column, April 14, 1879, p. 3 c. 1.

"Chinese Chapel Dedication", September 16, 1879, p. 3 c. 3.

"The Real Objective", editorial, November 11, 1880, p. 2 c. 1.

"The Manifesto of Riot", February 14, 1886, p. 5 c. 3-4.

"They Met. The Anti-Chinese 'Congress' in Session Yesterday", February 14, 1886 , p. 5 c. 3-4.

"Was There Danger of Riot?", editorial, February 17, 1886, p. 3 c. 4 .

"The Oregon City Outrage", February 23, 1886, p. 2 c. 1 .

"A Chinaman's Letter", February 26, 1886, p. 5 c. 5.

"Money Sent Out of the Country", February 26, 1886, p. 4 c. 1.

"Trumbell Lee's Letter", February 26,1886, p. 3 c. 4 .

"Another Chinese Outrage", March 5, 1886, p. 3 c. 3 .

"The Proceedings of Yesterday", March 17, 1886, p. 2 c. 1. 
"Munger's Anti-Chinese Bill", January 22, 1887, p. 2 c. 1-2. "Getting Ready to Vote", April 29, 1900, p. 24, c. 1.

"Not a Political Society", letter by Seid Back, Jr., April 30,1900, p. 5 c. 5 .

"Sends Letter to President", July 13, 1905, p. 9 c..3. "Chinese Union Rises Up", September 2, 1905, p. 5 c. 3. "Chinese Angry at Inspectors", October 5, 1905, p. 16 c. 1. "Chinese Consul Given Portland", October 2, 1906, p. 11 c. 3-4. "The Misunderstood Race Problem", editorial, February 11, 1907, p. 6 c. 3 .

"Where Our Women Do Not Belong", editorial, June 29, 1909, p. 8 C. 2 .

"Our Chinese 'Missions'", June 30, 1909, p. 8 c. 1-2.

"Three Ministers Tie Knot", January 12, 1910, p. 5 c. 2. "Chinese Prisoner Cannot Get Bail", October 5, 1910, p. 9 c. 1. "Cox Stops Gaming", October 9, 1910, S. 2 p. 18 c. 3. "'Tong' Wars Mainly Fakes", March 30, 1913, S. 6 p. 3 c. 6-7. "Labor Men Demand Asiatic Exclusion", November 19, 1913, p. 6 c. 3 .

"Speakers Urge Revolt", December 14, 1914, p. 4 c. 3. "Portland Chinese Fight Concessions", April 10, 1915, p. 12 c. 1 .

"Twenty-Fifth Anniversary Celebration of Chinese Mission in Portland Will Be Held Friday", February 16, 1916, p. 4 c. 2-3.

"Chinese Reared in America is Exiled", by C. H. Williams, April 12, 1916, p. 1 c. 7.

"Chinese Meet Here", June 15, 1916, p. 2 c. 4-5.

"City Officials Visit Mystic Chinatown", February 5, 1919, p. 18 c. 3 .

"'Barred-Door' Law Gets Knockout Blow", May 21, 1919, p. 5 c. 1. 
"Chinese Labor Opposed", November 23, 1919, p. 21 c. 4. "Secrets of Chinese Dives are Exposed", May 22, 1920, p. 21 c. 1 .

"Portland Chinese Unite", February 25, 1921, p. 4 c. 6. "Chinese Worry Over Vices of their Boys", June 19, 1921, p. 12 c. 5.

"Chinese Are Indignant", September 24, 1922, S. 1 p. 18 c.l. "Portland Chinese Sign Peace Treaty", November 3, 1922, p. 6 c. 1 .

"Four Lottery Cases Dropped as Illegal", August 14, 1924, p. 1 c. 4 .

"Raid Nets 11 Chinese", July 23, 1925, p. 9, c. 2.

"Chinese Urge Uncle Sam to Give Cupid Fair Show",February 22,1926, p. 5 c. 2-3.

"U.S. Guns She11 Cartonese Mobs", March 25, 1927, p. 1 c. 1 . "Unique Celebration Held by Chinese in Portland", December $18,1928, \mathrm{p} .4$ c. $2-3$.

"Fair Treatment Urged for Chinese Born in America", January 20,1929 , S. 1 p. 12 c. 5-6.

"Smuggled Men Exposed", April 23, 1931, p. 23 c. 2.

"Portland Banquet to Chinese Guests Delayed by U.S. Immigration Rules", May 19, 1933, p. 1 c. 4-5.

"Chinese Mourn Departure of Friend and Benefactor", October 14,1933, p. 8 c. 2-3.

"China Opens Consulate", October 17, 1933, p. 6 c. 6.

"Chinese Wear Identity Tags", December 20, 1941, p. 6 c. 6 .

"High Board Fence Hides Kindergarten Operated by Chinese Presbyterians", September 28, 1947, p. 16 c. 1-5.

"Bodies of 260 Chinese Being Exhumed for Trip", July 8, 1948 , S. 2 p. 1 .

"Magic, Miracles Key Services", by Ray Wolf, July 30, 1950, Magazine Section, pp. 6-7. 
"Bones Stay on Dock; Jail Holds Chinese", May 8, 1951, p. 1 c. 2-3.

"Portland Chinatown Ignores Tourist Appeal; Idols Gather Dust", February 15, 1953, p. A8 c. 1-5.

"Revived Chinatown?", editorial, March 9, 1961, p. I c. 1 .

"Government Charges Chinese Cook Weds Sister to Gain Entry into U.S.", April 25, 1964, p. 1 c. 5-7.

"Transaction Involving Oak Street Building Drops Curtain on Area's Old Chinatown", August 20, 1964, p. 33 c. 5-8.

"Nearly Last of City's Chinatown Buildings Will Be Razed for Downtown Parking Lot", July 15, 1965, S. 2 p. 2 c. 1-8.

"A Stroll Through Old Chinatown", by Ralph Friedman, December 25, 1966, Northwest Magazine, pp. 6-7 and 10 .

"Chinese Community Happy About 'Thaw"", April 17, 1971, p. 17 c. 2-3.

"Portland Chinese Favor Trip of Nixon", August 20, 1971, p. 35 c. 1-3.

"Tax Agents Seize Books of Three Chinese Tongs", July 11, 1975, p. A18 c. 6-8.

"Chinese Feel Overlooked in Minority Funding", August. 7, 1975, p. B9 c. 4-8.

"Chinese-American Women Make Organizational Gains", August 10, 1975, p. D2 c. 6-8.

"Chinatown Preservation Sought", February 22, 1976, p. Cl c. $1-2$.

"Portland's Chinese Gang Problems Low Level", October 9, 1977, p. E1 c. 2-5.

Articles cited from the Oregon Journal:

"Impressions and Observations of the Journal Man", by Fred Lockley, November 5, 1923, p. 4 c. 6-7.

"Chinese Students Like Volleyball", April 24, 1927, S. 1 p. 6 c. 2-3.

"Chinese Students of Coast Meet in Portland Friday", June 13, 1929, p. 1 c. 3 .

"Is Chinatown in Portland Going Occidental?", by Mary Patri- 
cia Moore, November 29, 1931, Magazine Section, p. 5.

"Tong Offers Reward for Chin's Slayer", September 10, 1934, p. 2 c. 2 .

"The Fact Is", by Fred Lockley, March 5, 1935, p. 6 c. 4-5.

"Chinese Center Discussed; Co-operation Assured", December 16,1943, p. 8 c. 6-7.

"Red Chinese Fraud Traps Portlanders", November 12, 1951, p. 1 c. 3-6.

"'Leper's Grave' Has New Marker", by Ann Reynolds Leo, May 29, 1955, p. IIM.

"This Was Portland", by Louise Arden, October 28, 1956, p. A9 C. $1-4$.

"'New Chinatown' Creation Urged; Plans Offered", March 23, 1961, Part 1, p. 16 c. 2-8.

Unpublished Works

Au, Kim Bik, "Economic Coping Patterns of Chinese Foreign Students in Portland State University", Master of Social Work practicum, Portland State University, 1976.

"CCBA Papers, 1908-1930", manuscript, Oregon Historical Society, (MSS 1459).

Chen, Chia-lin, "Chen Chia-lin's Translations (Articles Written by Portland's Chinese)", manuscript, Oregon Historical Society, Portland, 1973.

-.-- "A Gold Dream in the Blue Mountains; A Study of the Chinese Immigrants in the John Day Area, Oregon, 18701910", Masters thesis in History, Portland state University, 1972 .

-- -- "Interviews with Some Prominent Members of the Portland Chinese Community", manuscript, Oregon Historical Society, Portland, 1973.

- - "The Kam Wah Chung Company Papers. John Day, Oregon", manuscript, Oregon Historical Society, Portland, 1974. 1977.

Cheng, Paul, "Pastor's Report in the Congregational Meeting", 
Chinese Presbyterian Church, Portland, December 4, 1977.

Cheng Tso Ju, letter to Ulysses S. Grant dated April 17, 1883. Manuscript, Oregon Historical Society, Portland, (MSS 1521, "Ethnology--misc., Chinese").

Chinese Baptist Church, "Our 100th Anniversary, 1874-1974", pamphlet issued by the Chinese Baptist Church, Portland, 1974.

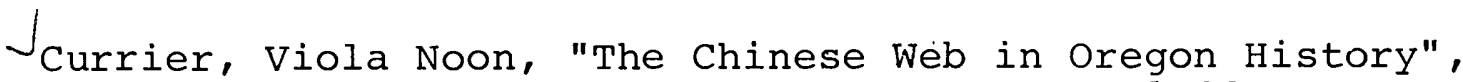
Masters thesis, University of Oregon, 1928.

Dalton, John B., "Marriage, Ethnicity, and Persistence in Portland, Oregon, 1860-1880", Bachelor's thesis in American Studies, Reed College, 1972.

$\checkmark$ Feller, Daniel M., "Get a Job: Occupational Structure and Social Mobility in Portland, Oregon, 1860-1880", Bachelor's thesis in American Studies, Reed College, 1972 .

Fong, Linda, "Occupational Prestige Among Chinese in the San Francisco Area", Master of Social Work practicum, Portland State University, 1974.

Gresham, W. Q., telegram to Sylvester Pennoyer dated May 8, 1888. Manuscript, Oregon Historical Society, (MSS 1521, "Ethnology-- misc., Chinese"i).

Gruza, J. A., "John Chinaman, How Did He Get Here?-- What Kind of an Animal Is He?-- What Shall we Do With Him?", Oregon Historical Society scrapbook, (SB 80, p. 58), c. $1870^{\prime} \mathrm{s}$.

Lee, Bessie Ying, "Perpetuation of Primary Group Patterns Among the Chinese in Portland, Oregon", Masters thesis in Sociology, University of Oregon, 1938.

Leung, Alex C. N., "Mental Illness Among Chinese in the United States: Myth or Reality?", Masters thesis in Psychology, Portland State University, 1976.

MacVeigh, Ellen, interview conducted by Charles DiGregorio in Portland, February 20, 1976, (tape cassette, Oregon Historical Society).

Montague, Helen Ruth, "Chinese Missions in Portland, Oregon", manuscript, Oregon Historical Society, Portland, (MSS 1147).

Oregon Historical Society scrapbook, (SB 6I, p. 198). 
Pennoyer, Sylvester, telegram to W. Q. Gresham, dated May 8, 1888. Manuscript, Oregon Historical Society, (MSS 1521, "Ethnology-- misc., Chinese").

Reed, Henry E., "Portland's First Census", manuscript, Oregon Historical Society, Portland, (MSS 383, Box 3).

"Sailor's Union of the Pacific Minutes, 1907-1910", Oregon Historical Society, Portland, (microfilm \#59).

ISing, Laura Lum, Wendy Po-kow Chan, and Peter Tan-ping Wong, "Chinese Attitudes and Knowledge Concerning Social Services: A Survey of the Portland Chinese Community", Master of Social Work practicum, Portland State University, 1973.

Tsai, Shih-shan Henry, "Reaction to Exclusion: Ch'ing Attitudes Toward Overseas Chinese in the United States, 1848-1906", Ph.D. dissertation in History, University of Oregon, 1970 .

U.S. Department of Commerce, Bureau of the Census, compilation of selected Asian groups by sex and census tracts for the Portland area, 1970. 


\section{APPENDICES}




\author{
APPENDIX A
}

INTERVIEW SCHEDULE AND CONTACT LETTER

SCHEDULE FOR INTERVIEWS WITH PORTLAND-AREA

CHINESE-AMERICANS

I. Life history data.

A. Family background:

1. Parents -- birthdates, place of birth, profession and social class in China (if applicable), profession and social class in U.S. (if applicable), parenting style (strict, "traditional", "Western", etc.)

2. Siblings -- number, sex, education, current situations, etc.

3. Recollections of statements of older relatives (parents, grandparents, etc.) concerning life in China or in the U.S.; conditions under which immigration to the U.S. was accomplished (if applicable); impressions of life in Portland and in Portland's Chinatown; etc.

4. Birthdate and place of birth of informant; marriage; number of children and current ages and situations; etc.

B. Immigration to Portland (if applicable):

1. Circumstances under which informant left China -- motivation, financial situation, image of what life would be like in the U.S., arrangements for employment upon arrival, etc.

2. Reasons for coming to Portland, other American cities where informant has lived, etc.

II. Impressions of life in Portland.

A. Living situation: impression of Chinatown life (if applicable), problems in obtaining suitable housing, feelings on the advantages and disadvantages 
of living in an ethnic community vs. living in the general community.

B. Employment situation: education, employment history, problems in obtaining suitable employment, financial difficulties, feelings about extent of employment opportunities open to Asians in Portland (both in the past and at present).

C. Acculturation: Extent to which informant has attempted to retain Chinese customs and values in his/her home or community life. Methods of raising children, problems attendent upon such methods, any experiences of a "generation gap" between parents and children due to cultural factors. Difficulties in learning the English language (if applicable). Difficulties in relating to American social norms and customs. Feelings about the advantages and disadvantages of assimilation into American culture.

III. Impressions of white American reaction to the Chinese.

A. Relationship with the white community:

1. Experiences of expression of racism, hostility or discrimination by whites, and how such experiences were dealt with.

2. Experiences of support or assistance provided by whites.

3. General feelings and impressions about white attitudes towards the Chinese, both in the past and at present.

B. Legal aspects of life in a white society: Know1edge of and experiences with anti-Chinese legislation (poll tax, tax on Chinese miners and merchants, exclusion legislation, etc.). Difficulties experienced in becoming a naturalized citizen (if applicable).

C. General statement of the informant on his/her perception of the main difficulties experienced by the Chinese in Portland.

IV. Mutual support organizations.

A. Chinese churches attended by informant: history of such churches, role played by the church in the community, services offered by the church. 
B. Community organizations with which informant has had experience or been a member: their history, extent of membership, goals, organization, services provided, source of funding, extent of success in meeting goals, etc.

C. Political activity in which respondent has engaged, or political organizations to which he/she has belonged. Feelings about political action as a tool of ethnic communities.

D. Labor organizations, farming cooperatives, merchant associations, etc. either within the Chinese community or in the broader society with which the informant has had experience. Feelings of the informant concerning the role of such organizations in Chinese community life.

E. Experiences of the informant in attempting to organize or take action on behalf of the chinese community.

F. Feelings of the informant concerning the directions of future activities in the chinese community, and the role of mutual support organizations in community life (what goals, strategies, funding sources, organizational structure, etc. such organizations should have).

G. Knowledge or experience concerning attempts at cooperating with other (non-Chinese) ethnic community groups, or other social organizations in general. Feelings about the validity and future of such cooperation.

H. Knowledge or experience with outside technical assistance or provision of resources to Chinese community groups, and feelings about the validity and future of such support. 


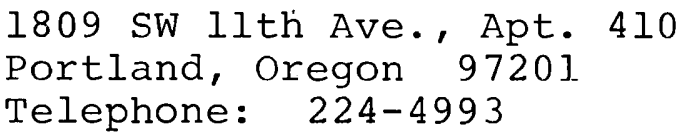

Dear Friend:

I am currently a graduate student in social work planning at Portland State University. All candidates for the Master of Social Work degree are required to do a thesis consisting of original research. I have selected as my thesis topic the history of community organizations among the ChineseAmericans in Portland.

In order to collect accurate information on this subject, I am trying to interview a wide range of people in the Portland Chinese community -- both community leaders and non-leaders. Your name was given to me as one who might be able to help me. I would therefore like to ask you if you would allow me to interview you. The interview would take about one hour, and would consist of questions about your personal history as a Chinese-American in Portland as well as information about any Chinese community organizations with which you have had contact. I could arrange to meet you at any place or time that is convenient for you. The interview will be tape recorded, but I will consider any personal information that you give me to be confidential. Also, I will be glad to provide you with a copy of the finished thesis, if you would like one.

I hope you will be able to help me. I will contact you by telephone sometime during the next week, and if you are interested we can at that time make arrangements for doing the interview. If you wish to get in touch with me, I can be reached in the evenings at the address and phone number above, or a message can be left for me by calling the PSU School of Social Work at 229-4712. I would be happy to answer any questions you may have about.my research.

I look forward to talking you to you soon. Thank you very much.

Yours sincerely,

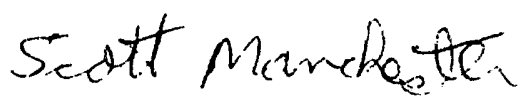




\section{APPENDIX B}

A CHRONOLOGY OF THE PORTLAND CHINESE COMMUNITY

1851 The first Chinese arrives in Portland from California.

1857 Oregon constitution denies Chinese the right to vote or hold mining claims.

1868 Burlingame Treaty calls for free immigration between China and the U.S.

1869 Chinese Methodist Episcopal Mission formed. YMCA opens school for Chinese.

1873 American Missionary Association establishes mission to Chinese in Portland.

Chinese school opens in St. Helen's Hall.

Anti-Chinese Association formed in Portland.

Portland City Coùncil passes cubic air ordinance.

1874 Chinese Baptist Mission established.

1875 Dong Gong ordained as pastor of Chinese Baptist Mission.

1878 City Council prohibits employment of Chinese in public works.

1879 Chinese Baptist Mission opens chapel at 5 th and Alder.

1882 First federal Chinese exclusion act passed.

1885 Dr. William S. Holt founds Chinese Presbyterian Mission.

1886 Following serious anti-Chinese violence all along the West Coast, anti-Chinese agitation occurs in Portland in February and March.

late $1880^{\prime} \mathrm{s}$ Tongs begin to move into Portland from San Francisco.

1888 Scott Act passed.

First tong war in Portland, between Bow Leong and Hop Sing Tongs, kills one and wounds three. 
$1890^{\prime} \mathrm{s}$ CCBA, and probably most family and district associations, established around this time.

1892 Geary Act passed.

1894 Portland Chinese Mission founded.

1898 American-Born Chinese Brigade established by Seid Back, Jr.

1900 American-Born Chinese Association established by Seid Back, Jr.

1904-1906 U.S. makes Chinese exclusion permanent; Chinese in southern China boycott U.S. goods in protest.

1906 May Back Hin made honorary Chinese Consul in Portland.

1908 Chinese Language School established.

1910. State charter given CCBA; CCBA building constructed; CCBA president is Leong Joo Hing. CCBA formulates new constitution.

1912 Hop Sing Tong leader assassinated by Bow Leong Tong.

1913 Two killed in tong war between Hop sings and Bow Leongs.

1914 Bing Kung and Bow Leong Tongs merge.

Portland branch of the Kuomintang is established about this time.

Six Chinese organizations mediate dispute between Bow Leong and Hop Sing Tongs; this develops into a Chinese Peace Society.

1915 CCBA raises funds for medical clinic.

1916 Chinese Bapist Mission moves to N.W. 6 th and Couch around this time.

Bing. Kung-Bow Leong Tong fights Hop Sings in February; two killed. Peace society arranges truce.

1917 Hostilities renewed as Bing Kungs and Hip Sings fight against Hop Sings and Suey Sings in February; four killed. Peace society arranges truce in April. But hostilities resumed in June and again in July, as three people are killed. Lee Mee Gun resigns as president of the Peace Society. A truce is finally made in september.

1921 Portland CACA chapter receives charter.

Three killed in tong war between Hop Sings and suey sings. 
1922 Tong war between Hop Sings and Hip Sings in April kills one; another tong war in June between Bing Kungs and Hip Sings also results in one death.

1923 Alien Land Bill passed in Oregon; Chinese and Japanese prohibited from owning land.

1924 U.S. Congress prohibits immigration of wives of Chinese.

1926 Rumors of imminent tong war between Hop Sings and Bing Kungs, but no war occurs. Period of tong wars in Portland is over.

1928 Ning Young District Association is established.

1931 CCBA opens soup kitchen and also sends 30 pilots to China.

Chinese Women's Club established; raises funds for Red Cross relief in China.

sing Shar youth club organized.

1933. CCBA reorganized; new consitution formulated. May Back Hin made official Chinese Consul in Portland.

1941 Yat Sing Music Club established.

1943 Chinese given right to become U.S. citizens; and Chinese exclusion is repealed.

1944 Chinese Baptist Church becomes independent.

late 1940's Many Chinese families move out of Chinatown; Chinatown $i$ becoming a residence for only a few bachelor men.

1948 CCBA makes its last shipment of bones to China.

1949 Chinese Baptist Church moves into new building at 1938 S.E. Ladd.

early 1950's Anti-Communist League formed by Bong Wai Chen; several Portland Chinese say Red Chinese have tried to extort money from them.

1950 Chinese Consulate in Portland closes.

1955 Chinese Language School closed.

1958 Chinese Language School reopened.

1961 CCBA constitution revised; all Chinese organizations given representation, as well as some at-large representatives. 
1965 Immigration laws liberalized; a wave of Asian immigrants begins to arrive in America.

c. 1966 Chinese Students Association established at P.S.U.

1970 A Chinese Evangelical bible study group begins meeting.

1972 CCBA investigates possibility of a Chinese nursing home, but idea is not implemented.

Chinese Language School begins cultural history and dance classes.

Leland Chin made honorary Chinese Consul in Portland.

Chinese Scientists and Engineers Association established.

1973 Holt Chinese Presbyterian Mission becomes an independent church, the Chinese Presbyterian Church.

Chinese Evangelical Church formed.

1974 Chinese Christian and Missionary Alliance Church formed from bible study group.

Portland Wah Ching youth group formed.

Chinese Consulate in Portland officially reopened.

1975 Chinese Physicians and Dentists Association formed.

1976 CCBA oral history project funded by CETA.

Chinese Presbyterian Church moves into new building at 7604 S.E. Clinton.

Chinese Christian and Missionary Alliance Church obtains a building at 8406 S.E. Morrison.

Hong Kong Chinese students separate from Chinese Students Association at P.S.U. and form their own group.

1977 . Chinese Information Service funded by CETA. 


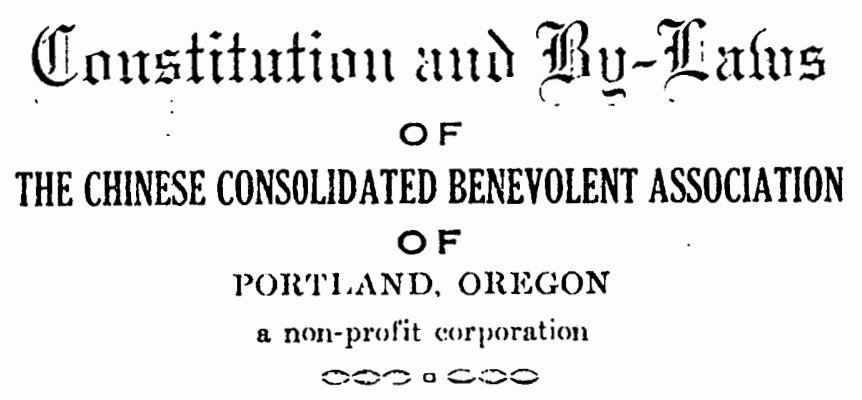

ARTICIAT I. NAME

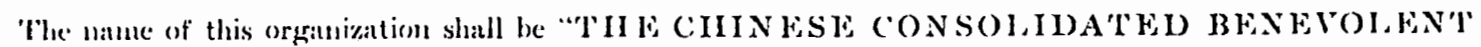

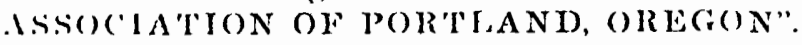

\section{ARTICLI: II. I.OCATION}

'The lowation of this orgainization shall be at $31.5 \mathrm{X}$.W. Davis Street, Portland 9, Oregon

\section{AR'TICIS HI. PURPOSE}

The purposes for which the organization is organized are:

a. 'T'o promote general welfare and good relations in the Chinese community.

b. $T o$ foster social, educational, and charitable endearors in the community.

\section{AR'ICIF IV. ORGANIYATION}

Whis organization shall consist of a General Assembly and an Executive Committee, and the President.

\section{Section 1. General Assembly}

a. All Chinese in the State of Oregon, 21 years of age or over, regardless of sex, shall be members of the General Assembly.

b. 'The General Assembly shall be the highest legislative body, and shall have the power to' makc the final decision on all unresolved matters.

(. The meeting of the General Assembly may be called at any time hy the. President, and may he called by at resolution passed by the Executive Committee.

d. The guorum of the General Assembly shitll be not less than 25 members.

Section 2. Hxecutive Committee

a. The Executive Committec shall be composed of:

1. One representative from each of the participating organizations of the Association as an alppointive executive committecman.

2. 17 members elected from among 30 candidates. nominated by the Fexecutive Committer and any Chinese business establishment.

b. The Association may' select at umber of Chinese civic leaders ass its Honorary committeemen. 


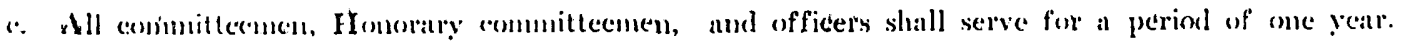
(Officers shall not serve consecutively for more than thrce years.

1. 'The regular meeting of the Wxecutive Committec shall be held once a month. Special neestings may be called at any timc $y$ the President, or may be called at the request of any five or more nembers of the lisecentive c'mmuttec.

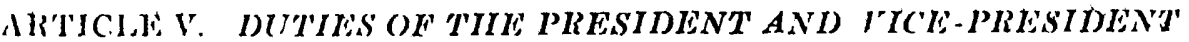

\section{S'cetion 1. Duties of the President}

a. Shall carry ont all the matters pertaining to the functions of the Association and shall act as be. presentative of the ureranization to outside persons or to other organized bodies.

b. Shatl direce and supervise all work of the various committees.

c. Shall preside at all meetings of the Hxecutive Committee and General $A$ sscmbly.

i. Shall alfix signalure torgether with the Vice-President and 'Treasurer to all checks in the lrauk acrounts of the Association.

\section{Section ״. Duties of the Vice-President}

a. Shall assist the l'resident in the discharge of his duties.

b. Shall act as President during the President's temporary absence, disability, or death.

c. Shall affix siguature together with the l'resident and 'Treasurer to all checks in the bank accountx of the Association.

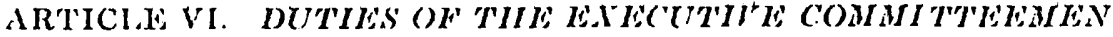

\section{Section 1.}

a. Homorary Committemen shall guide the Chinese people in his own community to assist the Association in fund-raising, public relations, and other civic affairs.

b. Fixceutive Committeemen shall attend all regular and special meetings of the Executive Committee and of the General $A$ sscmbly, and shall eary out the duty designated either by the President or by the Executive Committee.

\section{AR'ICLE VII. DUTIES OF TIIE OFFICWRS AND SUB-COMAITTELS}

'Ihe following officers and chaimen of each sub-(ommittee, except the Auditors and the liducation Subcommittec, shall be appointed by the President and Vice President, and shall be approved by the lixecutive ('ommittec.

\section{Section 1. Chinese Secretary}

a. Shall keep all the Association's Chinese dexuments and files, and shall attend to all ('hinese conrespondence and perform such duties as pertains to his office.

b. Shall kecp accurate and complete minutes of all meetings of the lisecutive Committee and Gencral Asscumbly.

\section{Section 2. English Secretary}

a. Shall keep all the Association's linglish documents and files and shall attend to all the Huglish correspendence and perform such other duties as pertain to his office.

b. May represent the President at English-speaking meetings.

‘. Shall be in charge of the Association Cemetery.

\section{Section 3. 'l'reasurer}

a. Slatl be in charge of and shall keep an accurate accomnt of all receipts and disbursements of funds; shiall make a nonthly report at the Executive Conumittee meeting; shall submit records to the Auditors for auditing every three months; shall make payments by check except payment of minor itcus; shall depessit in baink an! sum exceeding \$\$.j0.00 within one month of receipt.

b. Slatl affix sigmature togrether with the P'resident and Vice l'resident to all checks in the bank accounts of the Association, two af the thece signatures being sufficient for dishursenent.

(. Shall collect dues from the business and professional establishments. 


\section{Section 4. Auditors}

'Pwo anditurs shall be elected from anong five or more nominees by the Fxecutive Committee.

a. Shail andit all Pinancial records of the Asseciation every three months.

b. Shall andit financial records of all fund-raising campaignes of the Asserciation.

\section{Section 5. Fund-raising Sul-Committee}

a. Shall be in "harge of fund-rasing of the 1 sseciation, the Chinese liatlguage School, and other ap)rewed lund-raising cumpaigns.

Section 6. Welucational Sub-committee (School Board)

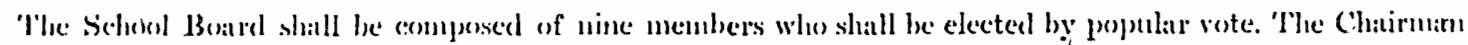

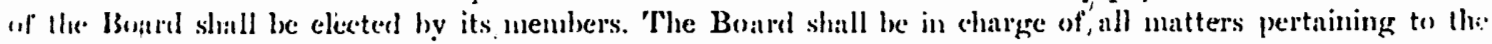
("hinesse lantguatge School.

\section{Section 7. Welfare Sub-Committee}

'The Welfure Sub-committe shatl he in chatrge of all matters pertaining to the welfare of the ('hinese (onmmunities in Gregon.

\section{Section 8. (hinesc News Sul)-Committee}

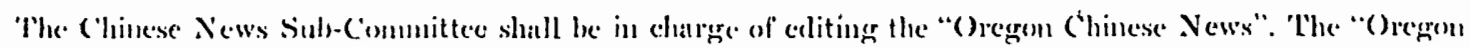
( "hinese' Nows" shall be self-supporting.

\section{Section !) Resolutions Siub-Committee}

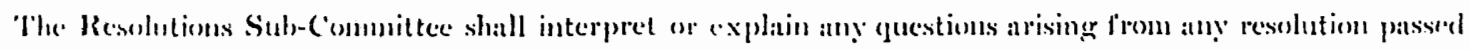
ly. Ulur. Isserriation.

\section{Y-1,AWS}

1. All of ficers and chaimen of the sub-committees shall be inembers of the Executive Committed. 'l'hey shiall attend cevery regular and special mectings of the Association.

2. T'he general election of the $\mathbf{A s s o c i a t i o n}$ shall he held on the first dayi of December. Installation of officers slatll be held on the second Sunday of January.

3. 'The chairmen of the sub-comnittees may reçuest assistance from any member of the Wxecutive Conmittec in carrying out their work.

f. Filection of the P'resident and Vice-P'resident

a. 'Tlie secretaly shall prepare the ballot, which shall be composed of one nominee from each participating organization, and 20 nominces selceted by the Fxecutive Committec, and shall bear the series number of the ballot, and the seal of the Association. It shall be given to various organizations and business firms for distribution to each individual voter.

b. 'The ballot shall be signed by the voter. Wach voter shall vote for one person from amonir the eandidates in the ballot. 'The ballots shall be returned within one week to the Assuciation, where they shall be sealed and kept until the next meeting of the dixecutive Committee, when the rotes shall be counted. Votes may also be cast on that day.

c. In case two or inore persons have the highest and equal number', of votes, the clection of the President shall be decided upon by drawing by the President.!

5. $\Lambda$ fine of $\$ 5.00$ shall be imposed on appointive committeemen for each absence from meetings. The fine shall be paid by the organizations which they represent. A fine of $\$ 1.00$ shall be imposed on the elective committeemen for each alsence from meetings. The elective committeemen maty be absent three times per year without fine. Also, they may be excused because of illness.

i. $\Lambda$ fec of $\$ 25.00$ shall be imposed on each burial in the Chinese cemetery. Exception shall be made to those unable to pay if the relatives or friends of the decensed testify to that effect, and if approved by the Association.

7. 'Two immediate past presidents shall be advisors of the Association.

x. This revised constitution shall be first approved by the Bxecutive Conmittec, and then referred to the General Assembly for final approval and adoption. It shall become effective within three months from the day of adoption. 
9. This constitution may be amended, deleted, or repealed by a vote of three-fourths of the members present, if a quorim is present, at a special meeting for the revision of the constitution called hy the Eisecutive Commitlee.

10. Rules of Order

a. 'Lhe l'resident shall have the iuthority to maintain and enforce order and rules of the meeting. as prescribed in the constitution after the meeting has been called to order.

b. More than one-half of the total membership shall constitute a (quorum for any Fxecutive Committce meeting.

(. Adoption of any resolution shall require a rote of a majority of the members present.

d. A motion must be seconded by two members.

c. A memher must atise his hatnd and be recognized by the chatir before he arises to speak.

f. A member shall not make more than three motions in any one meeting He shall not speat. mere than three times on :uny one proposit, or longer than five minutes at any one timu, except with the permission of the President, when the yuestion of explanation arises.

r. The l'resident shall rule out any irrelevant discussion to the question before the meeting.

h. A vote may be taken by counting or show of right himd or, il the question is importint, by ballot. When there is a tie vote, the President shall cast the deciding rote.

i. 'llac proposer of a motion at the mecting maty withdraw his motion if desired.

j. Infinislued propossals may be postponed until the next meeting.

k. During discussioms of a proposal, the l'resident shall maintain orderly procedure in such it manner that no other main motion shall be brought up until the one pending is disposed of.

Juthe 15. 1962

President

Sicretary

SOURCE: Oregon Chinese News, No. 7 (August, 1962). 